UNIVERSIDADE DE SÃO PAULO

FACULDADE DE FILOSOFIA, LETRAS E CIÊNCIAS HUMANAS DEPARTAMENTO DE HISTÓRIA PROGRAMA DE PÓS-GRADUAÇÃO EM HISTÓRIA SOCIAL

\author{
Mariana Bracks Fonseca
}

\title{
Nzinga Mbandi \\ e as guerras de resistência em Angola. Século XVII.
}

São Paulo

2012. 


\title{
UNIVERSIDADE DE SÃO PAULO
}

FACULDADE DE FILOSOFIA, LETRAS E CIÊNCIAS HUMANAS

$$
\text { DEPARTAMENTO DE HISTÓRIA }
$$

PROGRAMA DE PÓS-GRADUAÇÃO EM HISTÓRIA SOCIAL

\author{
Mariana Bracks Fonseca
}

\section{Nzinga Mbandi \\ e as guerras de resistência em Angola. Século XVII.}

\begin{abstract}
Dissertação apresentada para obtenção do título de Mestre em História Social, à Faculdade de Filosofia, Letras e Ciências Humanas da Universidade de São Paulo (USP), sob a orientação da Profa. Dra. Marina de Mello e Souza.
\end{abstract}

São Paulo 2012. 


\section{Agradecimentos}

A Deus primeiro, Nzambi-a-mpungo.

$\mathrm{O}$ meu mais profundo muito obrigada à minha orientadora, Profa. Dra. Marina de Mello e Souza, por toda a dedicação que tem com os estudos da História da África, pela generosidade em disponibilizar as principais referências bibliográficas aqui utilizadas, por todo o carinho com que sempre corrigiu e criticou meus textos, e principalmente, pela oportunidade de realizar este trabalho.

Agradeço à Profa. Dra. Maria Cristina Wissenbach, pelas preciosas sugestões feitas durante o exame de qualificação e durante os simpósios e encontros que organizou, favorecendo o amadurecimento dos pesquisadores em História da África. À Profa. Dra. Silvia Hunold Lara, pelas críticas e reflexões compartilhadas na banca de qualificação e pelo empréstimo do livro "Fontes para a história de Angola", fundamental neste trabalho. E ao Prof. Dr. Carlos Zeron, pelas lições sobre os jesuítas e colonização. Obrigada à Eliane, da Casa de Portugal, que disponibilizou a consulta de todo a coleção Monumenta Missionária Africana. Muito obrigada à FAPESP pela concessão da bolsa de pesquisa e dos recursos da reserva técnica.

Gostaria de agradecer minha família, em especial minha mãe, Fátima, por sempre me apoiar e possibilitar a realização dos meus sonhos, e a tia Tereza, pelo carinho e hospedagem. Muito obrigada ao meu companheiro Paulo, por me inspirar e ser o maior ouvinte das fabulosas histórias da rainha. Obrigada aos meus filhos, Indala e Uiran, que nasceram junto com este mestrado e que cresceram junto com minha imaginação.

Agradeço à Dona Mercês e à comunidade do Açude, onde pela primeira vez conheci o valor da nossa cultura africana. Enormemente, agradeço ao Mestre João e Dona Lena por terem me apresentado à rainha Nzinga, exaltada no espetáculo da Companhia Primitiva, e a todo o grupo "Eu sou angoleiro" por realiazem, a cada dia, a ginga de Angola. Obrigada a Mametu d'inkisse Muiandê, por manter aceso o Ngunzo, a rainha conga Isabel Casemiro e a outros tantos mestres da cultura popular que mantém as histórias da África vivas. 


\section{Resumo:}

Nzinga Mbandi é a mais famosa e controversa personagem da história de Angola no século XVII. Pretendemos neste trabalho, analisar a trajetória política de Nzinga tendo em vista o conturbado contexto da expansão da colonização portuguesa na África Central e da instituição do tráfico negreiro, principalmente durante o período em que representou maior oposição aos portugueses, nas décadas de 1620 e 1630. Buscamos compreender as estruturas de poder que haviam no reino do Ndongo antes da chegada dos portugueses e como o povo Mbundo se organizava política e economicamente. Entramos no debate historiográfico sobre quem eram os Jagas, como lutaram a favor dos portugueses e contra eles, ao lado de Nzinga. Buscamos entender como Portugal criou a colônia de Angola através do avassalamento dos sobas, construção de presídios, controle das feiras e composição de um exército africano que servia a seus interesses.

Nzinga Mbandi desempenhou diferentes papéis durante sua trajetória: cristã, Ngola, Tembanza, rainha de Matamba, etc. Buscamos compreender estes papéis face à disputa pelo controle do Ndongo, em que os portugueses a destituíram do trono e instituíram um novo rei em 1626, para isto, analisamos a questão da legitimidade e do poder feminino no reino do Ndongo. Entendemos Nzinga como a principal líder da resistência contra a presença portuguesa em Angola no período, pois além de dar asilo a centenas de escravos fugidos dos portugueses, impediu feiras e desorganizou a cobrança dos impostos.

Palavras-chave: Nzinga Mbandi, Angola, tráfico negreiro, resistência negra 


\begin{abstract}
:
Nzinga Mbandi is the most famous and controversial character in the history of Angola in the 17th century. We intend, in this dissertation, to analyze the political trajectory of Niznga in the trouble contex of expanding Portuguese colonization in Central Africa, ando $f$ the slave trade, principally in the 1620's and 1630's, during which Nzinga represented the major opposition to the Portuguese. We attempt to understand the Power structures in the Kingdon of Ndongo before the Portuguese arrived, and how the Mbundo people organized themselves political and economically. We consider the historiographical discussion abou Who the Jagas were, and how they fougth beside the Portuguese and agaist them. We also seek to understand how Portugal created the colony of Angola by the subjulgation of sobas, by building prisions, controlling markets and organizing na African army to serve their interests.

Nzinga Mbandi played different roles during her trajectory: Christian, Ngola, Tembanza Jaga, Queen of Matamba, etc. We analyze these roles in the contexto $f$ the struggle to control Ndongo, when the Portuguese ousted her from the throne and replaced her with a new king in 1626 . We considered the questiono f legitimacy and feminin Power in the Ndongo and Matamba kingdons. We understand that Nzinga Mbandi was the most important leader of the resistance agains the Portuguese presence in Angola in this period, because she gave asylum to many fugitives slaves, obstructed markets and disrupted tax collection.
\end{abstract}

Key-words: Nzinga Mbandi, Angola, slave trade, Black resistance. 
“Ê Nzinga

A rainha que veio de lá

Resistiu com seu povo na dança

E hoje a terra é do samba"

Lena Santos. Poethorias Afro-

Companhia Primitiva de Arte Negra 


\section{Nzinga Mbandi e as guerras de resistência em Angola. Século XVII.}

\section{Sumário:}

Introdução .08

Capítulo 1. O reino do Ndongo.

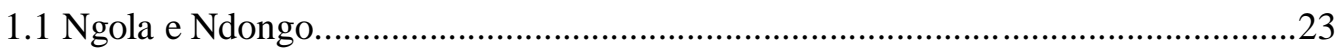

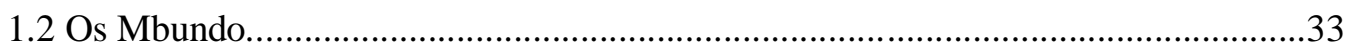

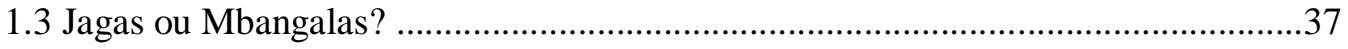

Capítulo 2. Angola portuguesa: Conquista e resistência

2.1. Formação da colônia portuguesa de Angola...............................................54

2.2 Submissões dos sobas, baculamentos e "instituição dos Amos"...................63

2.3 As guerras angolanas: "Guerra Preta”, Jagas mercenários............................76

2.4 Itinerários do tráfico negreiro: feiras e presídios.........................................95

Capítulo 3. Nzinga Mbandi e a luta pelo Ndongo

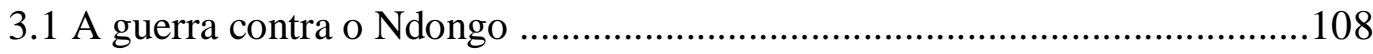

3.2 Dona Anna de Sousa: batismo e paz .......................................................113

3.3 Nzinga Mbandi, senhora de Angola........................................................121

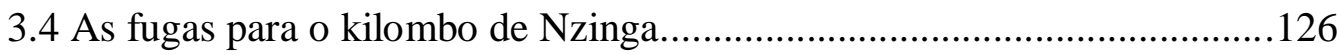

3.5 O golpe político de Fernão de Sousa ..................................................131

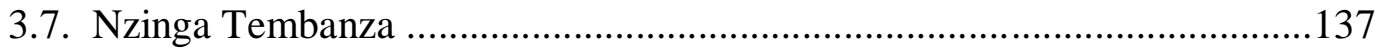

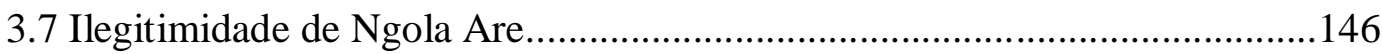

3.8. Poder feminino e legitimidade no Ndongo e em Matamba...........................154

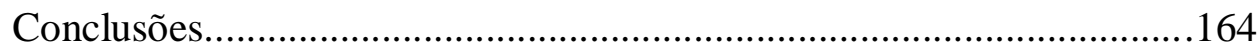

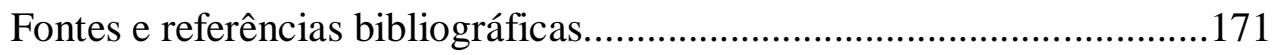




\section{Introdução:}

\section{Nzinga na literatura e na historiografia}

Nzinga Mbandi é uma das mais famosas personalidades da história centro-africana e a mais bem documentada rainha de Angola. Muito se escreveu sobre Nzinga, desde o século XVII, com diferentes matizes e abordagens.

A literatura europeia a descreveu como uma tirana selvagem, de comportamento bizarro e hábitos canibais. No século XVIII, Castilhon destacou seu posicionamento político contraditório e sua personalidade ambivalente, afirmando que ela buscou alianças com os portugueses para destruir seus inimigos africanos e para se enriquecer com o tráfico de escravos, efetuando uma política colaboracionista, alheia a ética e a acordos. ${ }^{1} \mathrm{Na}$ visão de mundo iluminista, os governantes africanos eram ambiciosos, usurpadores, infiéis e foram responsabilizados pela existência da escravidão e pela crueldade que se abatia sobre o povo. Os rituais africanos, sobretudo dos Jagas, aparecem como "açougues públicos de carne humana", em que a matança indiscriminada e as orgias sexuais foram narradas para mostrar ao leitor europeu como os brancos eram civilizados diante dos bárbaros negros, tudo isso com a seleção de uma linguagem pintada de sangue a fim de provocar choque, asco e estranhamento ao leitor. As religiões africanas foram associadas a atos satânicos, assim Nzinga, enquanto viveu como Jaga, teria perdido seu caráter humano e foi representada como uma besta, um animal à procura de sangue, entregue aos ritos diabólicos. O romance francês "Zingha, Reine d'Angola", de forma literária, explorou a homossexualidade de Nzinga, sem nenhuma base documental. Ela aparece vestida como homem, enquanto seus vários "concubinos" se travestiam de mulher e a tratavam como rei. O arquétipo da heroína canibal, "femme fatale", capaz de assassinar e comer seus amantes e inimigos, não demorou a encontrar ecos no pensamento da época e aguçou as ideias "libertinas". Marquês de Sade, leitor de Castilhon, apropriou-se da personagem criada por seu colega e lhe rendeu homenagens no seu delirante reino psico-sexual de Butua em "Aline et

\footnotetext{
${ }^{1}$ Castilhon, J.-L. Zingha, Reine d'Angola. Histoire Africaine. Bourges: Edition de l'Association Gaymede, 1993. Primeira edição de 1770, disponível em www.europeana.eu.
} 
Valcour". 2 Nzinga foi também citada em "La philosophie dans le boudoir", em que Sade viu nela um exemplo de revanche feminina sobre a dominação masculina, contribuindo para a repercussão da imagem da rainha negra antropófaga, tirana e sodomita.

Mais tarde, no século XIX, Hegel reforçou esta visão ao afirmar que a história não poderia existir na África, pois ali o homem estava na barbárie, no estado selvagem, ainda sem a capacidade de formar uma cultura. Provavelmente, Hegel baseou-se nos escritos de Castilhon e Sade ao referir-se a Nzinga, que é citada nominalmente em seus estudos como estereótipo da tirania e barbaridade. ${ }^{4}$

Historiadores portugueses, no século XX, tentaram omitir a hostilidade de Nzinga para com os portugueses e reforçaram, ao invés, sua conversão ao catolicismo e as relações harmoniosas que ela mantinha com os missionários e com outros governadores em Luanda durante os últimos anos de sua vida. ${ }^{5}$ Nesta perspectiva, claramente associada aos projetos coloniais que ainda eram mantidos em Angola, estes historiadores tentaram minimizar a atuação política e militar de Nzinga, mas a colocaram como coautora do tráfico negreiro, na tentativa de legitimar a atividade e transferir a culpa da escravidão aos chefes africanos.

O belga Curvelier contribuiu para a divulgação da história de Nzinga pela Europa no século XX, mas seu trabalho é bem romanceado, com muitos exageros e imprecisões. ${ }^{6}$ Não utiliza base documental e a opinião do autor é evidenciada em vários momentos, em que os preconceitos em relação aos africanos e o ponto de vista próportuguês são marcantes, mantendo a perspectiva colonialista européia. Curvelier continuou enxergando Nzinga como uma tirana canibal, mas extremamente sedutora e

\footnotetext{
${ }^{2}$ Sade, Donatien Alphonse François de. Aline et valcour. LGF- Livre de Poche, 1994. E Delon, Michel e Malandain, P. Littêrature française du XVIIIe.siècle. Paris, PUF, 1996. p.399.

${ }^{3}$ Sade, Donatien Alphonse François de. La philosophie dans le boudoir. (1795). Paris, 1976. E Sauvage, Emmanuelle. Sade et l'exotismoe africain: images de Noirs. In: Erudit, études litteraries. v. 37 n.3, 2006. pp.97-116.

${ }^{4}$ Hegel,G.W. La raison dans la histoire. Paris, 1965.

${ }^{5}$ Delgado, Ralph. História de Angola. Vol.II e vol.III. E Corrêa, Elias. História de Angola. Lisboa: Agência Geral das Colônias, 1937.

${ }^{6}$ Curvelier, Jean. L'ancien royaumme de Congo. Fondation, decouverte, premiere evangelisation de l'ancien royaume de Congo, regne du grand roi Affonso Mvemba Nzinga. Bruxelas: Desclée de Brouwer, 1946.
} 
perspicaz. O autor deu maior ênfase à aproximação de Nzinga com o cristianismo, valorizando, sobretudo a ação dos missionários capuchinhos.

Em Angola, Nzinga foi exaltada pelos movimentos políticos, nas décadas de 1960-1970, como uma líder da resistência "proto-nacionalista", sendo a única heroína em comum exaltada tanto pelo MPLA como pela UNITA. ${ }^{7}$ Esta abordagem incorre no erro de apresentar conceitos impertinentes para o século XVII, como o de "nação" e "luta de classes" e acabaram por exagerar o papel político de Nzinga na luta contra o colonialismo, sem se embasarem nos documentos históricos. Contudo, refletem o modo com que a imagem de Nzinga ficou registrada nas tradições e no imaginário angolano ao longo dos séculos.

A partir da década de 1960, novos estudos surgiram de historiadores não portugueses, menos vinculados aos interesses coloniais. Estas pesquisas inovaram por tentarem reconstruir a história sob a perspectiva africana, buscando entender a organização dos antigos reinos que existiam na África Central antes da chegada dos portugueses. ${ }^{8}$ Desta forma, analisaram Nzinga no âmbito da política interna do Ndongo e Matamba, evidenciando seu papel como líder da resistência Mbundo.

Na década de 1970, surgiram os trabalhos de Miller, que se distinguem pela ampla pesquisa de campo junto aos habitantes de Malanje, utilizando as tradições orais e propondo uma nova metodologia para abordar a história de Angola. ${ }^{9}$ Miller analisou profundamente a estrutura interna e ideologia da política africana e defendeu que Nzinga travou uma constante batalha para legitimar sua sucessão contra os opositores que a viam como uma usurpadora incapaz de governar enxergando uma coerência nas diversas alianças construídas por Nzinga ao longo de sua carreira política. ${ }^{10}$

\footnotetext{
${ }^{7}$ Abranches, Henrique. MPLA. Historia de Angola. Porto, I976. E UNITA: Identity of a Free Angola. Jamba, 1985. Citados por Heywood e Thornton. Central africans, atlantic creoles, and the fondation of the Americas, 1585-1660 .p.131.

${ }^{8}$ Vansina, Kingdons of Savana.(1966), David Birmingham. Trade and Conflict in Angola.(1966) E Rodney, W. 'European Activity and African Reaction in Angola'.Em Ranger, Terence 0. Aspects of Central African History . (1968)

${ }^{9}$ Miller. Poder político e parentesco: os antigos estados Mbundu em Angola. Trad. De Maria da Conceição Neto. Luanda: Arquivo Histórico Nacional, 1995. Título original: Kings and Kinsmen: early Mbundu States in Angola. Oxford: Claredon Press, 1976.

${ }^{10}$ Miller, "Nzinga of Matamba in a new perspective". The Journal of African History. V.6, n.2, 1975.
} 
Roy Glasgow apresentou um trabalho menos meticuloso no que tange ao uso e análise das fontes primárias, de linguagem mais literária e com muitas interpretações pessoais sem sustentação em evidências documentais. ${ }^{11}$ Seu trabalho é interessante, pois faz um paralelo entre as lutas de Nzinga em Angola e os quilombos no Brasil, sobretudo Palmares. Apesar de o título expressar a resistência de Nzinga frente ao colonialismo, o autor oscila em seus posicionamentos, enxergando-a ora como líder independente, ora como uma mulher seduzida pelas riquezas europeias e a coloca como co-autora do tráfico de escravos a partir de Matamba.

Beatrix Heintze é uma autora de grande importância para a História de Angola, pois propôs uma abordagem diferenciada de cruzamentos das fontes e fez um meticuloso estudo sobre metodologia, conciliando fontes orais e escritas. ${ }^{12}$ A ela devemos a publicação da documentação do governador Fernão de Sousa, que trouxe novas luzes à questão mais crucial para este estudo. ${ }^{13}$

Adriano Parreira realizou um trabalho de antropologia social em que sistematizou os dados contidos em vários documentos históricos, produzindo uma ferramenta interessante para o historiador atual. ${ }^{14}$ Parreira reexaminou o trabalho de Miller e criticou suas conclusões e pressupostos, argumentando que Nzinga tinha mais legitimidade do que Miller defende, sobretudo porque foi beneficiado pela larga consulta aos documentos de Fernão de Sousa, publicados por Heintze depois que Miller fez sua pesquisa.

John Thornton é outro importante pesquisador da vida de Nzinga e das relações culturais na sociedade angolana do século XVII. Travou intensos debates com Miller, levantando novas questões sobre a legislação e composição étnica no reino do Ndongo.

\footnotetext{
${ }^{11}$ Glasgow, R. Nzinga.Resistência africana à investida do colonialismo português em Angola, 1582-1663. São Paulo Editora Perspectiva, 1982.

${ }^{12}$ Heintze, B. Angola nos séculos XVI e XVII. Estudos sobre Fontes, Métodos e História, Luanda: Kilombelombe, 2007.

${ }^{13}$ Heintze, B. Fontes para a história de Angola. Vol.I. Memórias, relações e outrosmanuscritos da Colectânea Documental de Fernão de Sousa (1622-1635). 1985 e Vol.II. Cartas e documentos oficiais daColectânea Documental de Fernão de Sousa (1624-1635). 1988.

${ }^{14}$ Parreira, Adriano. Economia e sociedade na época da rainha Jinga. (Século XVII). Lisboa: Editorial Estampa, 1997. E Dicionário glossográfico e toponímico da documentação sobre Angola, séculos XVXVII. Lisboa, 1990.
} 
Para ele, Nzinga conseguiu se legitimar no poder e tornou-se precedente do poder feminino. Junto com Linda Heywood, Thornton formulou o conceito de "Atlantic crioles culture", sugerindo uma nova forma de pensar a interpenetração da cultura europeia com a africana. Neste sentido, a trajetória política de Nzinga foi pensada em termos de aceitação ou não dos elementos da cultura estrangeira.

\section{E por que mais uma vezfalar de Nzinga Mbandi?}

Percebemos que, mesmo com a grande quantidade de trabalhos publicados sobre Nzinga, sua trajetória politica não é conhecida o suficiente no Brasil. Neste momento, em que a História da África é estimulada, os professores da educação básica não sabem sequer citar reis ou rainhas africanos. Nzinga Mbandi, para nós, é um excelente exemplo para contrapor a dominação europeia na África, é um exemplo de como os chefes africanos não aceitaram pacificamente a colonização e lutaram, militar e ideologicamente, para que seus estados permanecessem livres e independentes. Entendemos Nzinga Mbandi como uma grande estrategista política e militar, que durante sua longa e conturbada trajetória, soube usar das mais diversas artimanhas para se livrar do cerco empreendido pelos governos portugueses que desejavam reduzi-la à submissão.

Não pretendemos fazer uma biografia de Nzinga, mas sim analisar sua atuação politica e militar no contexto da ocupação portuguesa do território angolano. Para isto, tornou-se necessário entender as relações de poder e a composição étnica e cultural existentes no reino do Ndongo antes da chegada dos portugueses. No primeiro capítulo da presente dissertação buscamos analisar o significado da insígnia Ngola e como se deu o processo de centralização do Ndongo buscando entender como o poder político central se articulava com as autoridades regionais e o que ele representava para a população Mbundo. Para entender a complexidade do cenário do Ndongo, buscamos entender quem era o povo Mbundo, regido sob a autoridade Ngola, como se organizava e como produzia suas riquezas, já que este se tornou um dos principais alvos da escravidão em Angola no século XVII.

Um povo que rodava pela África Central nos séculos XVI e XVII nos chamou especial atenção: os Jagas ou Mbangalas. As fontes mostram que a atuação deste povo foi decisiva para a história de Angola em diversos momentos, tanto ao lado dos 
portugueses como mercenários para o desenvolvimento do tráfico negreiro, tanto ao lado de Nzinga. A ação dos Jagas foi tão ambígua quanto à designação pela qual foram chamados, levando a um intenso debate na historiografia. Fizemos um resumo do que a principal bibliografia disse sobre a identidade dos Jagas, buscando compreender quem eram os Jagas das fontes do século XVII, como se organizavam, quais seus principais ritos e mitos, para enfim entender sua atuação política.

O segundo capítulo trata da chegada dos portugueses no reino do Ndongo e da construção da colônia chamada Angola, focada principalmente no tráfico de escravos. Buscamos entender como os agentes coloniais se articularam com o poder político tradicional através do avassalamento dos sobas, entender o sistema de tributação a eles imposto e perceber como os portugueses penetraram no interior através da construção de presídios e feitorias. O estado de guerra foi constante, então voltamos nossa atenção para a composição da "guerra preta" - os exércitos negros que lutaram para a escravização de outros africanos- bem como as táticas e os instrumentos bélicos empregados nas batalhas.

A atuação política de Nzinga Mbandi é o tema central da presente dissertação e concentra-se no terceiro capítulo. Para comprender quem foi Nzinga Mbandi e sua atuação, alegadamente confusa e ambígua, buscamos entender o contexto da colonização portugesa e as lutas políticas em torno do trono do Ndongo. Entendemos que a guerra movida pelo governador Luiz Mendes de Vasconcelos, em 1617 contra Ngola Mbandi, foi o início do processo de subjugação do reino do Ndongo, que gradativamente foi perdendo sua independência. Nzinga Mbandi teve atuação determinante neste processo e desempenhou importante papel (papéis) no combate à presença portuguesa em Angola.

Nossa pretensão inicial era dar conta de toda a trajetória da personagem, até o momento da sua reconversão ao catolicismo e sua morte como cristã, aos 80 anos de idade. Mas esta longa vida foi tumultuada demais, e repleta de "vai-e-véns", com diferentes nuances e estratégias de ações. Optamos por nos focar no período em que Nzinga ofereceu maior resistência à empresa colonial, em que as rivalidades foram mais explicitadas e que a luta pelo controle político do Ndongo foi mais intensa, expresso pelo golpe articulado pelo governador Fernão de Sousa em 1626. Neste momento, 
considerado decisivo para a história de Angola, Nzinga marcou sua posição contra a colonização e foi duramente perseguida pelo governo português, levando-a a aliança com os Jagas. Buscamos compreender o significado de cada papel representado por Nzinga (cristã, Ngola, Tembanza) no contexto das disputas coloniais e da instuição da escravidão atlântica. Reabrimos as discussões historiográficas sobre legitimidade e poder feminino do Ndongo e Matamba, buscando entender a importância de Nzinga na luta pela independência dos estados centro-africanos diante da tentativa portuguesa de manipular os precendentes e alterar os governantes.

Pensamos "conquista" e "resistência" em Angola não como um simples binômio de opostos, mas como um complexo cenário, em que as diversas forças combatiam de forma ambígua e variável. Não se trata de brancos contra negros, muito menos de europeus contra africanos. O jogo de alianças era flutuante o bastante, não permitindo tais simplificações. Mas mantivemos a ideia de Nzinga como líder da resistência africana frente ao colonialismo europeu e à consolidação do tráfico negreiro, destacando sua atuação militar e política. Militar porque queremos entender como Nzinga, com seu exército de Jagas, desorganizou a rede comercial que Portugual penava para construir, quais as táticas, estratégias, armas utilizadas para se manter livre e desestabilizar a presença do inimigo em Angola. E política porque reuniu em torno de si centenas de pessoas das mais diferentes etnias e encabeçou a formação de grande confederação de sobas descontentes com a presença portuguesa na África Central, reunindo-os em torno de uma causa comum.

\section{Fontes e metodologia}

Este trabalho se caracteriza pelo uso abundante das fontes primárias publicadas e pelo cruzamento destas fontes. Infelizmente, ainda hoje não temos disponível documentação escrita que forneça o ponto de vista dos africanos. Utilizamos fontes escritas pelos europeus, o que exige atenção do historiador para filtrar as intenções embutidas na documentação. Entendemos a fonte histórica segundo as propostas da "nova história cultural", pensadas como representações dotadas de historicidade e 
intencionalidade, buscando compreender as suas condições de produção, circulação e apropriação. $^{15}$

Os escritos dos jesuítas, sobretudo, devem ser analisados com cuidado, pois tudo o que foi escrito foi direcionado a fim de se criar uma imagem da colonização, convencer as autoridades régias da necessidade das intervenções que eles julgavam pertinentes, garantirem-lhes o controle - religioso e econômico - da colônia. Os jesuítas fizeram importante trabalho em Angola, não só de evangelização - o que é muitas vezes questionado, pois a catequese parece não ter sido o objetivo principal desses padres na África - mas principalmente de registro historiográfico. As numerosas correspondências dos jesuítas que serviam na África, hoje nos dão bases para refletir sobre diversos pontos da História de Angola. Escreveram não apenas sobre o exercício religioso, mas também sobre as relações de poder tradicionalmente existentes e os conseqüentes conflitos com o poder português; descreveram a natureza, com seus alimentos e animais exóticos; narraram as batalhas de conquista do território; falaram de temores e esperanças da colonização. Foram tantos os pontos discutidos pelos jesuítas que o aspecto religioso ficou em segundo plano na maior parte das missivas.

A importância das fontes missionárias é tamanha que a Agência Geral do Ultramar, a partir de 1952, começou a publicá-las em uma coletânea intitulada "Monumenta Missionária Africana”. Coligidas e anotadas pelo padre Antônio Brásio, a Monumenta soma 15 volumes, reunindo documentos dos anos 1471 a 1699. Revisitamos a Monumenta Missionária Africana, exaustivamente estudada por vários pesquisadores (Delgado, Paiva Manso, Carlo Alberto Garcia, Elias Corrêa, Thornton), como se fosse inédita, buscando informações que pudessem acrescentar na formulação da história de Angola, sempre atento às estratégias discursivas de quem escreveu o documento. Tentamos corrigir os eventuais erros de interpretação que possam ter ocorrido nos sucessivos processos de tradução nas obras de Heintze e Thornton. Agradecemos à Casa de Portugal, em São Paulo, por ter disponibilizado o acesso à coletânea completa da Monumenta Missionária Africana. As referências a esta obra aparecem ao longo da dissertação com o nome do organizador: Brásio, seguido pelo volume e a página de onde o documento foi tirado.

\footnotetext{
${ }^{15}$ Chartier, Roger. A história cultural entre práticas e representações. Trad. Port. Lisboa, DIFEL, 1990, p. 27
} 
Além dos jesuítas, os capuchinhos foram importantes "historiadores" de Angola no século XVII. Cavazzi nos deixou um registro interessantíssimo sobre os reinos do Congo, Angola e Matamba, em que analisou não somente o trabalho evangelizador, mas também os ritos, mitos, vestuário, hábitos alimentares, festas dos povos daquela região. ${ }^{16}$ Dissecamos o olhar eurocêntrico de Cavazzi, acompanhando o argumento central de sua narrativa: o catolicismo, sendo a verdadeira religião, deveria vencer as bárbaras religiões africanas. Em seu ímpeto historiador, o capuchinho criou uma metodologia própria e curiosa, ainda que não tenha tido esta consciente intenção. Além de realizar intensa pesquisa nos Arquivos da Propaganda da Fide e da Sagrada Congregação, o padre registrou tudo aquilo que viu e ouviu durante os anos em que exerceu o trabalho missionário nestes reinos. Cavazzi compilou diversas tradições orais existentes no século XVII e as condensou em uma narrativa única, ignorando as diferentes origens dos mitos.

A maior parte do tempo que esteve na África, Cavazzi permaneceu na nova capital do reino do Ndongo, Mpungo-a-Ndongo, onde governava o maior inimigo da rainha Nzinga, Ngola Are. Devemos considerar que as informações que ele obteve acerca do período de intensa rivalidade entre os dois podem ter sido influenciadas por este fator, já que seus informantes lhe narravam os episódios segundo o que lhes interessava registrar.

O olhar eurocêntrico de Cavazzi é facilmente percebido. O capuchinho analisou os costumes locais segundo os seus próprios costumes e julgamentos morais, mantendo sempre o distanciamento e o estranhamento de um observador europeu. Os Jagas foram descritos como bestas selvagens, sedentos por sangue e pela carne humana. Seus ritos foram descritos como "execráveis seitas", "festas do demônio", "luxuriosos rituais", "ritos bestiais", etc. Cavazzi enxergou o demônio cristão em tudo e julgava todos rituais que eram estranhos à sua cultura como possessões do demônio, que tinha numerosos servos entre os africanos, entendidos como escravos do mal. Cavazzi apresenta uma visão notadamente anti-africana, em que o pecado era inerente à condição do ser negro. $\mathrm{O}$ vício estava profundamente enraizado nestes habitantes da chamada Etiópia e o

\footnotetext{
${ }^{16}$ Cavazzi, Giovanni Antonio. Descrição histórica dos três reinos do Congo, Matamba e Angola. 2 volumes. Lisboa : Junta de Investigações do Ultramar, 1965
} 
missionário chegou a duvidar da possibilidade da conversão real entre eles. A demonização dos Jagas reforça seu argumento principal: Nzinga Mbandi, que vivera como uma Jaga entre os anos de 1626 a 1656, estava perdida nas trevas e na barbárie e foram os capuchinhos que a conduziram para a verdadeira luz de Cristo. Para aumentar a glória da evangelização capuchinha, Cavazzi pintou uma rainha sanguinária, "implacável contra os inimigos", "ávida de carne humana", "infernal megera”. Nas páginas em que narrou a vida Jaga de Nzinga (pp.64-102, vol.II), o missionário não poupou desqualificativos, descrevendo massacres e canibalismos para impressionar o leitor europeu.

Cardonega é outra fonte indispensável em um estudo que pretende discutir as estratégias de conquista e resistência empreendidas nas guerras angolanas. ${ }^{17} \mathrm{O}$ capitão português reformado que serviu em Angola por mais de quatro décadas deixou uma narrativa riquíssima em detalhes. As batalhas foram minuciosamente descritas e as dinâmicas políticas e o sistema de alianças foram revelados nos três volumes da História Geral das Guerras Angolanas. Os dois primeiros são dedicados a narrar os principais fatos em cada governo, desde Paulo Dias de Novais. O terceiro volume é um estudo quase antropológico em que descreveu os hábitos, crenças, ritos dos povos de Angola. A obra de Cardonega é fundamental porque, como ele mesmo justificou, os documentos sobre os primeiros anos da ocupação portuguesa em Angola foram jogados no rio Kwanza pelos holandeses invasores. No entanto, o historiador não pode se esquecer que o olhar de Cardonega mostra a postura das tropas portuguesas. Talvez isto torne a narrativa ainda mais interessante, pois ele usa adjetivos bem expressivos para qualificar Nzinga, refletindo o julgamento que se fazia dela no calor dos fatos. ${ }^{18}$

As ilustrações que compõem o frontespício de cada volume apresentam interessantes representações sobre o poder na "Etiópia Ocidental". Os desenhos mostram as vestes dos principais chefes políticos da região, armas, insígnias de poder e os elementos da natureza que o simbolizavam.

\footnotetext{
${ }^{17}$ Cardonega. História geral das guerras angolanas.( 1681). 3 vols. Ed. Anot. Cônego José Mathias Delgado (vols.1 e 2) e Manuel Alves da Cunha (vol.3). Lisboa, 1972

${ }^{18}$ Para uma análise da importância de Cardonega enquanto fonte histórica, ver. Heintze. Angola nos séculos XVI e XVII. Capítulo 5 "A obra de António de Oliveira de Cadornega: uma fonte extraordinária para a História e Etnografia de Angola no século XVII".
} 
Contudo, a obra de Cardonega exige atenção do historiador pois apresenta graves erros cronológicos, que graças ao trabalho do anotador dos primeiros volumes, Cônego José Mathias Delgado, puderam ser corrigidos. As notas de rodapé escritas por este estudioso permitem acessar outras fontes que foram transcritas, como as relações de Manuel Severim de Faria e cartas de Fernão de Sousa.

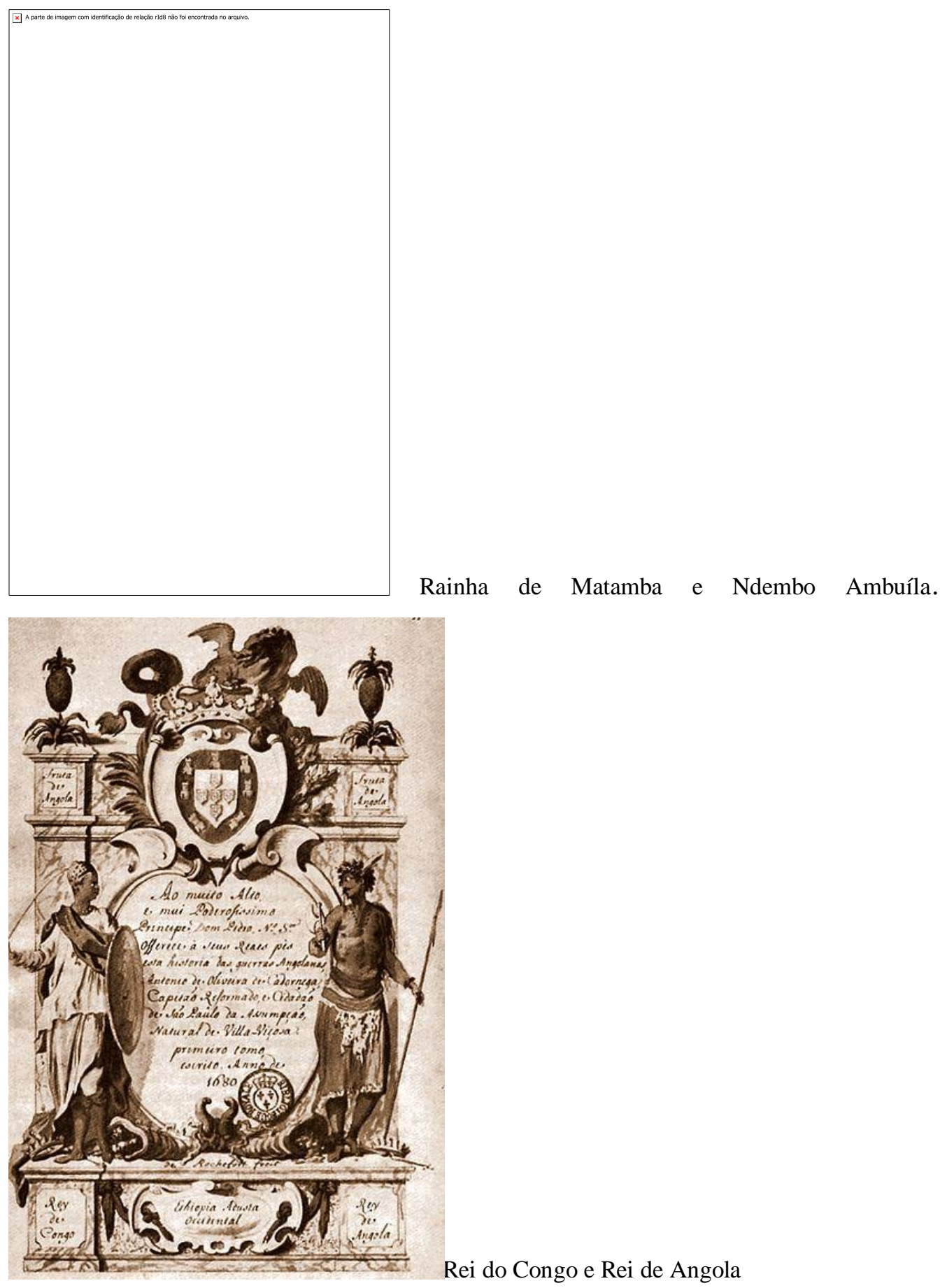

Em Cardonega. Frontespício.Vols.I. e II. Em: WWW.minhaangola.org acesso em junho de 2012. 
O acesso ao corpus documental legado pelo governador Fernão de Souza e publicados por Beatrix Heintze ${ }^{19}$ deu novas luzes a este estudo, pois revelam fatos e pontos de vistas de um personagem diretamente inserido nas guerras angolanas, mais que isto, são os registros oficiais do governador que deu o golpe e deflagrou a maior campanha de perseguiçã a Nzinga. Estes documentos permitiram repensar a articulação do golpe político de 1626 e seus reflexos, bem como rediscutir a questão da legitimidade do poder no reino do Ndongo. Alguns documentos são interessantíssimos, pois revelam a mudança do posicionamento de Fernão de Sousa em relação à Nzinga ao longo do seu governo. O "extenso relatório" 20 que o governador enviou a seus filhos é uma narrativa em retrospectiva dos principais fatos que ocorreram em Angola entre 1624 e 1630, explicitando o ponto de vista do governador. Interessante observar como Fernão de Sousa utilizou os vocábulos africanos ao escrever a seus filhos. Agradeço à minha orientadora Marina de Mello e Souza por ter disponibilizado um exemplar do segundo volume de Fontes para a história de Angola e à professora Silvia Hunold Lara, por ter disponibilizado o primeiro volume. Sem estes livros, sem dúvida, a pesquisa teria tomados outros rumos.

Fontes administrativas também foram encontradas em coletâneas documentais como as de Felner e Cordeiro. ${ }^{21}$ Os escritos de homens do governo nos permitem desvelar as estratégias de colonização, as ordens régias e o descompasso entre o que a Coroa mandava e o que era cumprido em Angola.

A metodologia adotada foi a comparação e cruzamento das diversas fontes. Por vezes, nos deparamos como incoerências entre as fontes, principalmente ao que se refere à cronologia, que tentamos explicitá-las e corrigi-las ao longo da dissertação.

\footnotetext{
${ }^{19}$ Heintze, Beatrix. Fontes para a história de Angola. Vol.I. Memórias, relações e outrosmanuscritos da Colectânea Documental de Fernão de Sousa (1622-1635). Studien zur Kulturkunde, Bd. 75. Stuttgart: Steiner 1985. E Fontes para a história de Angola. Vol.II. Cartas e documentos oficiais da Colectânea Documental de Fernão de Sousa (1624-1635).Studien zur Kulturkunde, Bd. 88. Stuttgart: Steiner 1988.

${ }^{20}$ Extenso relatório do governador a seus filhos. 1630. Em Heintze, Fontes para a história de Angola. Vol.I. 1985. doc.30.

${ }^{21}$ Felner, Alfredo de Albuquerque. Angola. Apontamentos sobre a ocupação eo inicio do estabelecimento dos Portugueses no Congo, Angola e Benguela extraídos de documentos históricos. Coimbra: Imprensa da Universidade, 1933. E Cordeiro, Luciano. Questões Histórico- coloniais. Lisboa: Agência Geral das Colônias, 1935. V.1
} 
Juntamente com o uso das fontes, dialogamos com a historiografia existente sobre a História de Angola e sobre a vida de Nzinga. Além de reconstruir os episódios históricos, levantamos questões sobre como a historiografia enxergou tais eventos, evidenciando a interpretação de cada autor, e tentando dar a nossa contribuição para o debate.

\section{O problema linguístico}

Estudar a história de Angola no Brasil esbarra em um sério problema: como grafar as palavras da língua kimbundo? Resolvemos transformar este problema de escrita em um problema epistemológico da reconstrução da história angolana.

O problema se inicia logo na escrita do nome da nossa personagem principal, pois este foi grafado de diversos modos: Nzinga, Njinga, Jinga, Ginga, Zingha...

Levamos em consideração que o kimbundo, na ocasião da chegada dos europeus em Angola, era uma língua sem escrita, e esta foi introduzida pelos brancos. Assim, os portugueses que estipularam uma grafia para as palavras em kimbundo, utilizando as regras que regiam o português, optando pela utilização da letra "Q", ao invés do "K".

A partir da independência de Angola, em 1975, visando à valorização, utilização e promoção das línguas locais, o Instituto de Línguas Nacionais de Angola fixou as normas ortográficas do kimbundo e outras línguas maternas, optando pela ampla utilização da letra "K". ${ }^{22}$ De acordo com estas normas, foram grafadas Nzinga, Kwanza, kilombo.

Apesar da maioria dos autores de língua inglesa ter adotado a grafia "Nzinga", Thornton optou por escrever "Njinga", pois lhe pareceu que correspondesse às regras da nova ortografia do kimbundo, conforme a referência bibliográfica que ele utilizou. ${ }^{23}$ Confessa ter sido convencido por Graziano Leguzzano, o editor de Cavazzi, estudioso

\footnotetext{
${ }^{22}$ Em http://pt.wikipedia.org/wiki/L\%C3\%ADnguas_de_Angola, acesso em março de 2012.

${ }^{23}$ Kounta, Maria Celeste. Histórico sobre a Criação dos Alfabetos em Línguas Nacionais. Lisboa, 1980,p. 64. Em Thornton, Legitimacy and political power. P.25.
} 
que viveu durante muitos anos em Angola, grande conhecedor do kimbundo e que optou por escrever "Jinga".

Neste trabalho, optamos por grafar as palavras de origem angolana de acordo com que os angolanos convencionaram (Nzinga, Kwanza, Ndongo...). Mas percebemos que esta opção, por vezes, choca-se com a grafia das fontes portuguesas, trazendo uma série de dificuldades na interpretação das informaçõese na construção do texto. Percebemos que as fontes portuguesas também não eram concenssuais na forma de escrever as palavras africanas (nem mesmo as palavras portuguesas tinham regras ortográficas fixas no século XVII) e, às vezes, uma mesma fonte escreveu de formas diferentes a mesma palavra, tornando o nosso trabalho ainda mais dificil.

Foi um desafio padronizar a grafia de vários nomes próprios, que se tornou uma decisão arbitrária escolher. Optamos por Are e não Ari, mas não conseguimos encontrar uma explicação razoável para isto. Chamamos atenção para o nome "Cassanje", que aparece escrita de várias formas nas fontes. Adotamos a proposição de Heintze, que adotou a ortografia de Henrique de Carvalho, chamando "Cassanje", o Jaga, também conhecido como Kulaxingo, e "Casanze" o mani da Nsaka. ${ }^{24}$ Optamos por utilizar "kilombo", para designar a organização militar Mbangala, diferenciando de "quilombo", nome que foi adotado para tratar a organização dos escravos fugidos no Brasil. Ao se referir à obra historiográfica, preservamos a grafia adotada pelo autor, o que pode trazer dúvidas ao leitor, por exemplo, Vansina escreveu Kinguri e Henrique de Carvalho, Quinguri.

Privilegiamos a grafia banta para a escrita dos nomes das etnias: Mbundo e não Ambundo, Mbangala e não Imbangala. Com letra maiúscula e sempre no singular. O leitor pode se deparar com contradições na opção gráfica, em que algumas palavras foram mantidas com a letra "Q", ou "aportuguesadas". Peço desculpas pelos eventuais deslizes, mas a História de Angola ainda está em construção, e esbarra na necessidade de padronização da grafia utilizada pelos historiadores. Fica registrada aqui a necessidade de melhor discutirmos as questões concernentes à escrita da história africana.

\footnotetext{
${ }^{24}$ Heintze, B. Angola nos séculos XVI e XVII. P.284. nota 28.
} 
Esperamos que o presente texto seja prazeroso e possa contribuir para a melhor compreensão das sociedades africanas e de como o tráfico negreiro foi ali estabelecido, com alianças e guerras. Que o conhecimento da trajetória política de Nzinga Mbandi possibilite a reflexão sobre as formas de resistência que sempre existiram contra o colonialismo na África. Esperamos que achem interessante acompanhar como Nzinga desempenhou diversos papéis, como aceitou o batismo abençoada pelo governador e lutou como Jaga, como reivindicou o trono do Ndongo enquanto exercia a soberania em Matamba, como defendeu os Mbundo assumindo o principal título Mbangala, como foi rainha chamada de rei. Que as várias faces de Nzinga Mbandi tragam a consciência de que os africanos foram governados por reis poderosos e rainhas guerreiras, que muitos não aceitaram a submissão e lutaram de todas as formas para evitar a escravidão. Assim, nós, afro-descendentes, teremos mais consciência que nossos ancestrais não foram simplesmente escravizados ou co-autores do tráfico negreiro, mas que resistiram e lutaram pela liberdade! 


\title{
Capítulo 01. O reino do Ndongo
}

\subsection{Ngola e Ndongo}

\begin{abstract}
"Dizem os naturais que este foi um tal Ngola-Mussuri, o que quer dizer 'rei-serralheiro', a quem um ídolo tinha ensinado a arte fabril. Pode ser que este homem, mais perspicaz que os outros, achasse a maneira de preparar o ferro, para machados, machadinhas, facas e setas, coisas que ajudavam os Pretos na caça e na guerra e foram para o artista grande fonte de riqueza. Como usava delas com sagacidade e socorria a todos nas necessidades públicas, ganhou amor e o aplauso dos povos, de tal maneira que, por conhecerem nele grande capacidade e tino singular, muitos régulos o proclamaram chefe do país, que se chamava "Ndongo" ou de Angola." 25
\end{abstract}

Este é o mito fundador do Ndongo, que se centralizou em torno do título Ngola, tal como foi registrado pelo capuchinho Cavazzi no século XVII. Cardonega também registrou que o primeiro Ngola foi um ferreiro, comentando que este ofício era muito estimado entre os Mbundo. ${ }^{26}$

Juliana Ribeiro da Silva analisou a recorrência do mito de rei ferreiro na África Central, e demonstrou que poder e técnicas da metalurgia estão intimamente relacionados, tanto no plano simbólico como no material. ${ }^{27}$ Nas sociedades da África Central, o ferreiro possui a capacidade de acessar o mundo invisível, o que o diferencia dos demais mortais. A imagem do rei ferreiro agrega em si os poderes mágicos deste ofício, dando maior legitimação a este soberano, que por não precisar recorrer a outro profissional, pode reinar autônomo. Seu poder garante a fertilidade da terra e a reprodução de seu povo, já que o ferro possibilita a construção de ferramentas para agricultura e para a guerra que odefendia.

Joseph Miller analisou as insígnias de poder na formação dos reinos da África Central e ensinou que os jingola (plural de ngola) eram pedaços de ferro, originalmente, objetos de formas definidas como um martelo, um sino, uma enxada ou uma faca. Essencialmente, o ngola era um mediador entre o mundo dos vivos e dos mortos da

\footnotetext{
${ }^{25}$ Cavazzi. Descrição Histórica dos três reinos: Congo, Angola e Matamba. Vol. I. p. 253

${ }^{26}$ Cardonega. História Geral das Guerras Angolanas. Vol. I. p. 25

${ }^{27}$ Silva, Juliana Ribeiro. Homens de ferro. Os ferreiros na África Central do século XIX. Dissertação de Mestrado defendida na USP. Julho de 2008. pp.41-53.
} 
linhagem e ajudava seu guardião a resolver disputas pela prática da adivinhação e davalhe apoio para decidir questões referentes ao bem-estar de seus parentes. ${ }^{28}$

Por ser uma insígnia móvel - diferente de outras insígnias do universo Mbundo, como a árvore malemba, que marca o território e a malunga, cujo poder é derivado de rios ou lagos - o ngola libertou as linhagens das amarras a uma terra determinada e permitiu o deslocamento do grupo, sem que se desagregasse. Sendo transportáveis física e simbolicamente, as linhagens passaram a se mover livremente em busca de novas oportunidades de comércio, guerra e outras circunstâncias. Algumas linhagens Mbundo transformaram o ngola, de insígnia de linhagem, no fundamento de um novo tipo de estrutura política. Ao criarem instituições políticas centralizadas e hierarquizadas com base no ngola, as linhagens inverteram o significado estrutural de uma insígnia que, inicialmente, chegara aos Mbundo como apenas mais uma, numa longa série de idéias e símbolos absorvidos pelo sistema linhageiro dos Mbundo. A posse da insígnia ngola garantiu poder político àquele que seria, a partir daí, chamado de Ngola.

A posição Ngola-Kiluanje era formada por uma rede de alianças entre as diferentes linhagens, que reconheciam a autoridade deste título dominante. No século $\mathrm{XVI}$, a genealogia Ngola detinha os principais títulos e as mais prestigiadas posições entre as linhagens Mbundo. O título Ngola- Kiluanje podia ser conquistado, atribuído ou reivindicado por qualquer linhagem ou indivíduo, era a principal posição política no Ndongo à qual estavam associados outros títulos hierarquicamente subordinados. $\mathrm{O}$ título Ngola tornou-se, no Ndongo, um novo tipo de estrutura política centralizada e hierarquizada, estabelecendo ruptura com as normas tradicionais dos grupos de descendência Mbundo. A partir da reunião de poderosos exércitos, pôde impor sua soberania a praticamente todas as formações sociais entre os rios Bengo, Kwango e Kuvo. O comércio, que acompanhou a expansão militar, foi integrado numa estratégia de distribuições de títulos e posições entre as linhagens, permitindo aos ocupantes do título Ngola-Kiluanje influenciar linhagens muito distantes e se estender para muito além de suas fronteiras étnicas, o que Parreira chamou de "Diáspora A-Ngola". ${ }^{29}$

\footnotetext{
${ }^{28}$ Miller. Poder político e parentesco. P.63.

${ }^{29}$ Parreira, Adriano. Economia e sociedade na época da Rainha Jinga. p.176.
} 
O Ngola era, no princípio do século XVI, tributário do maniCongo, que se intitulava "rei do Congo, senhor dos Ambundos". ${ }^{30}$ Assim como o reino de Matamba, o Ngola foi paulatinamente conquistando autonomia ao longo do século XVI. Heywood e Thornton afirmam que o Ndongo só emergiu como força política independente a partir da segunda década do século XVI. ${ }^{31}$ A batalha do Ndande (1556) marcou definitivamente a independência do Ndongo em relação ao Congo, quando o maniCongo tentou submeter o Ngola pelas armas, mas foi derrotado pelo potente exército do vassalo rebelado.

O Ndongo foi se constituindo enquanto reino centralizado em torno do Ngola, a quem muitos sobas prestavam homenagem e pagavam tributos anuais. Vansina considera que este processo de centralização não ocorreu de uma única vez em todo o reino e a conquista de novos territórios se deu de forma paulatina, e muitas vezes alicerçada na guerra. ${ }^{32}$ A centralização competia com a autonomia dos sobas e o Ngola se articulou com os líderes locais, ou lutou contra eles, para impor seu poder. O reino centralizado oferecia maior proteção ao povo que pôde se dedicar mais à agricultura e assim possibilitar o crescimento populacional.

Os sobas reconheciam a autoridade do Ngola, pois o consideravam sagrado, detentor de poderes especiais que garantiam a fertilidade e o bem-estar da comunidade. "O Ngola se dizia o rei do sol e da chuva", 33 seus poderes mágicos garantiam as chuvas tão necessárias e era também o responsável por lançar as primeiras sementes na terra. ${ }^{34}$

Para Vansina, a adoção de um estado "monocefálico" foi apenas um tipo de governança escolhido dentre outras possibilidades. ${ }^{35}$ Proclamar o Ngola como o garantidor da chuva, da fertilidade e da defesa tornou-se a opção preferida devido à "imaginação coletiva" que se fascinava por noções de poder, fama e centralização. A

${ }^{30}$ Cartas do rei do Congo D. Afonso. Introdução, notas e comentários e modernização do texto por Antonio Luiz Ferronha. Grupo de Trabalho do M. da Educação para as comemorações dos Descobrimentos Portugueses.

\footnotetext{
${ }^{31}$ Heywood-Thornton.Central Africans, Atlantic Creoles and America.P.54

${ }^{32}$ Vansina, Jan. How societies are born. 2004. P.201-205

${ }^{33}$ Garcia Simões para o provincial. Brásio.vol.III, p.134.

${ }^{34}$ Cavazzi.Vol.I.p.254. e Heintze. Angola nos séculos XVI e XVII. P.57.

${ }^{35}$ Vansina, Jan. How societies are born. 2004. P.204-205
} 
formação de uma "corte" ou a distribuição de títulos pelas elites e sobas foi um meio de concretizar este sonho.

Heintze optou por chamar de Ndongo o estado africano que se constituiu em torno do título Ngola, opção esta que seguimos. Mas ressalva que possivelmente os próprios africanos não tivessem originalmente uma designação territorial que abarcasse a totalidade do território dominado por Ngola Kiluanje. ${ }^{36}$ Segundo esta autora, o Ndongo era provavelmente apenas o nome da sua província mais importante. Cardonega registrou que o reino do Ndongo era "mui estendido e dilatado" e seus limites eram marcados por árvores chamadas Ensandeiras que foram mandadas plantar pelos "Reys antigos de Angola como sinaes certos dos limitres do seu Reino e sua demarcação." ${ }^{37}$

O poder político do Ngola era constituído pelos sobas que lhe eram tributários. Os sobados eram unidades politicas autônomas que compunham o reino do Ndongo, e os sobas, dentro de suas terras, eram "Senhores de baraço e cutello, sem dependência de seu Rey". ${ }^{38}$ No entanto, o Ngola deveria proteger as comunidades Mbundo contra ataques de forasteiros e garantir a paz em todo o território. Até o início do século XVII, o Ngola estava ampliando seus domíniosà medida que os sobas aceitavam seu poder. Com base em diversos textos jesuítas do século XVI, Heywood e Thornton contabilizaram 736 sobados independentes que reconheciam a autoridade do título Ngola. ${ }^{39}$ Frequentemente os sobas entravam em guerra por territórios e jurisdição, e os séculos XVI e XVII devem ser considerados como um período de grande instabilidade política no Ndongo, interna e externamente.

O Ngola era servido por vários funcionários reais, revelando um estado burocratizado, com oficiais especializados e divisão do trabalho. O Ngola Mbole era um dos principais cargos, equivalia a Capitão geral da gente de guerra. O Tendala representava o governo político em todas as terras do Ngola. Os macota (plural dikota) eram os mais velhos, assistentes ou "camaristas" do conselho de paz e guerra que decidiam as coisas mais importantes do estado. O muenelumbo era o responsável por

\footnotetext{
${ }^{36}$ Heintze. Angola nos séculos XVI e XVII. P. 277.

${ }^{37}$ Cardonega. Vol.I p.26.

${ }^{38}$ Idem.p. 39.

${ }^{39}$ Heywood-Thornton. P.73, com base no texto do padre Baltasar Barreira em Brásio. Vol.III, p.227, c.1582-1583 e Pero Rodrigues. História da Residência dos Padres da Companhia de Jesus em Angola. Em Brásio.Vol.IV,p.561, 1/5/1594 e Informação do reino de Angola, em Brásio. Vol.XV, p.364-7,c.1590.
} 
guardar as cercas e muros do reino. Havia servidores responsáveis para guardar as roupas do Ngola, o muenemuseto e o muenequizola ${ }^{40}$ para cuidar da alimentação. Os mesmos cargos apareciam de forma análoga nos sobados.

Várias fontes falaram das muitas "esposas" que os Ngolas tinham - mais de trezentas segundo Cardonega - e seus milhares de filhos. Era considerado prestígio unir uma filha com o Ngola, assim muitos sobas davam suas filhas para viverem com o soberano, e da mesma forma o Ngola mandava suas filhas como presentes aos sobas. ${ }^{41}$

O Ngola era, portanto, um soberano poderoso que governava autônomo um Estado hierarquizado, com complexa organização social e tributária, contava com diversos "funcionários públicos" e centenas de sobas tributário. O Ngola aparece também como "capaz de reunir rapidamente numeroso exército", ${ }^{42}$ garantindo seu poder militar.

Cardonega anotou que o reino do Ndongo era composto pelas províncias da Ilamba, Lumbo, Massangano, Mosseque (divida entre Mosseque e Gango), Are, Umba (Quituxila), Quissama e Libolo. O Kwanza era o rio mais importante e conectava o interior ao litoral, onde se formou a cidade portuguesa de Luanda, mais tarde São Paulo de Assunção. A capital Cabaça era a "Corte e assento deste poderozo Rey de Angola". ${ }^{3}$ O reino de Matamba, também chamado Ndongo Oriental, era o limite a leste e o rio Zenza demarcava a fronteira com o reino do Congo ao norte.

\footnotetext{
${ }^{40}$ Cardonega. Vol.I.P. 32. Cavazzi. Vol. I. p. 104.

${ }^{41}$ Cardonega. Vol.I. P. 30.

42،Carta do padre Franciso Gouvéia”, em Brásio Vol.IV p.362. e Cardonega.vol.I. P. 30.

${ }^{43}$ Cardonega. vol.I. P. 32.
} 
Em Heintze, B. Angola nos séculos XVI e XVII. P.173.

O início do século XVI foi um momento em que os reinos da África Central buscavam ampliar seus domínios à medida que desenvolviam novas tecnologias. $\mathrm{O}$ domínio da metalurgia possibilitou que os reinos crescessem e se armassem, e neste contexto tanto o Ndongo como Matamba passaram a reivindicar a autonomia em relação ao Congo, deixando de lhe pagar tributos e constituindo poderes independentes. ${ }^{44}$ Miller localizou a origem do ngola nas terras altas da bacia do Lukala, em Matamba, onde viveram o povo samba, os que primeiro dominaram as técnicas da metalurgia e transmitiram o símbolo ngola aos Mbundo.

A genealogia do título Ngola ainda é uma incerteza para a historiografia. Títulos e pessoas se confundem nas listas nominais referentes ao princípio do século XVI. Não havia regras claras de sucessão previamente estabelecidas e o poder político não passava automaticamente de pai para filho em caráter hereditário.

${ }^{44}$ Miller, J. Poder político e parentesco. Cap. 3 
Segundo uma fonte de 1582-1583, "o reino de Angola começou no bisavô do que agora reina, porque antes todo era de Senhores particulares, que não reconheciam a ninguém sobre si."

Cavazzi, a partir das tradições orais, registrou a seguinte ordem para a genealogia dos Ngola: ${ }^{46}$

1. Ngola Musuri, ou rei-serralheiro

2. Zunda-dia-ngola

3. Tumba-dia-ngola

4. Ngola Quiluanji Quiassamba

5. Ndambi Ngola

6. Ngola Kuiluanji Kia Ndambi

7. Nzinga Ngola Kilombo Kia Kasenda

8. Mbandi Ngola Kiluanji, morto em 1617.

A narrativa de Cavazzi é repleta de assassinatos de possíveis herdeiros, fratricídios e usurpações, o que reforça seu argumento de barbárie entre os africanos pagãos. A objetividade da narrativa de Cavazzi deve ser questionada, pois ele interpretou as tradições orais que ouviu no século XVII segundo o que lhe convinha. ${ }^{47}$ Tendo em vista que Cavazzi provavelmente ouviu esta história através de interlocutores pertencentes às linhagens Ngola Kiluanje, podemos inferir que sua genealogia oculte uma atitude etnocêntrica da linhagem em relação ao seu próprio passado, para legitimar ideologicamente a sua hegemonia sobre outras linhagens, como a de Are-Kiluanje, que disputava o poder central no Ndongo no momento em que Cavazzi lá estava.

Jan Vansina chamou atenção para o uso das tradições orais, advertindo-nos que os relatores muitas vezes selecionam o "que é bom lembrar" pois uma lenda histórica é sempre o discurso de uma determinada linhagem ou clã que busca justificar e

\footnotetext{
${ }^{45}$ Brásio.Vol.III. p.227

${ }^{46}$ Cavazzi. Descrição histórica dos três reinos.p.83. Afirma que o oitavo Ngola, também chamado de Jinga-Ngola-Mbandi, era o pai de Ngola Mbandi e Nzinga Mbandi.

${ }^{47}$ Como ele mesmo confessou em Cavazzi.Op.cit. Vol. I. p.40.
} 
reivindicar, através da narrativa, "os privilégios e reinvindicações dos direitos desaparecidos". 48

Os estudos de Miller revolucionaram a compreensão que tínhamos das genealogias dos reinos africanos e tornou ainda mais difícil a reconstrução de listas nominais dos Ngola. Sua pesquisa das tradições orais em Malanje mostrou que os nomes evocados por Ngola Inene, Kiluanje Kya Samba e Ngola a Kiluanje eram títulos perpétuos e não pessoas físicas e representavam princípios abstratos de poder. ${ }^{49}$ Miller deu nova interpretação às palavras "filho", "pai", "irmão", "casamento", revelando o caráter metafórico destas expressões nas genealogias centro-africanas: "pai" e "filho" revelam relações políticas entre títulos, sendo um derivado do outro, tal como "irmão" seria uma equivalência entre os títulos. Esta terminologia que utilizamos se refere a uma relação política e não biológica. As árvores genealógicas se referem assim a títulos políticos (posições masculinas) e a grupos de parentesco (posições femininas).

Beatrix Heintze acredita que as tradições orais recolhidas passam por um longo processo de estruturação, formatação e reformulação. ${ }^{50}$ Para ela, que concorda com as inovações de Miller, a centralização do Ndongo e instituição do título ngola foi um longo processo de mudança e adaptação das realidades locais. O primeiro rei seria "um símbolo personificado de todo o período inicial”, assim Ngola inene ou Ngola mussuri não foi necessariamente uma única pessoa que conseguiu se impor, mas as tradições o condensaram em um personagem com nome próprio. $\mathrm{O}$ mito fundador do rei ferreiro não é exclusividade do Ndongo, mas sim uma "lenda migratória muito divulgada". ${ }^{51} \mathrm{O}$ nome Kiluanjique integrava o título dos reis dos Ndongo significa conquistador, o que pode confirmar a hipótese de que este primeiro rei fora um forasteiro que submeteu a região, como as tradições narram.

\footnotetext{
${ }^{48}$ Vansina, Oral tradition. Chigago, 1966. E Once upon a time: oral tradition as History in Africa. Daedalus.c.2.1971, 442-468.

${ }^{49}$ Miller. Joseph. Poder político e parentesco. P. 189 e seguintes.

${ }^{50}$ Heintze. Angola nos séculos XVI e XVII. P.176.

${ }^{51}$ Idem. P. 177. Nota 42.
} 
Idílio do Amaral sistematizou tabelas de possíveis genealogias a partir de diferentes fontes e autores. Heintze sugeriu três hipótesespara a genealogia do título Ngola: ${ }^{52}$

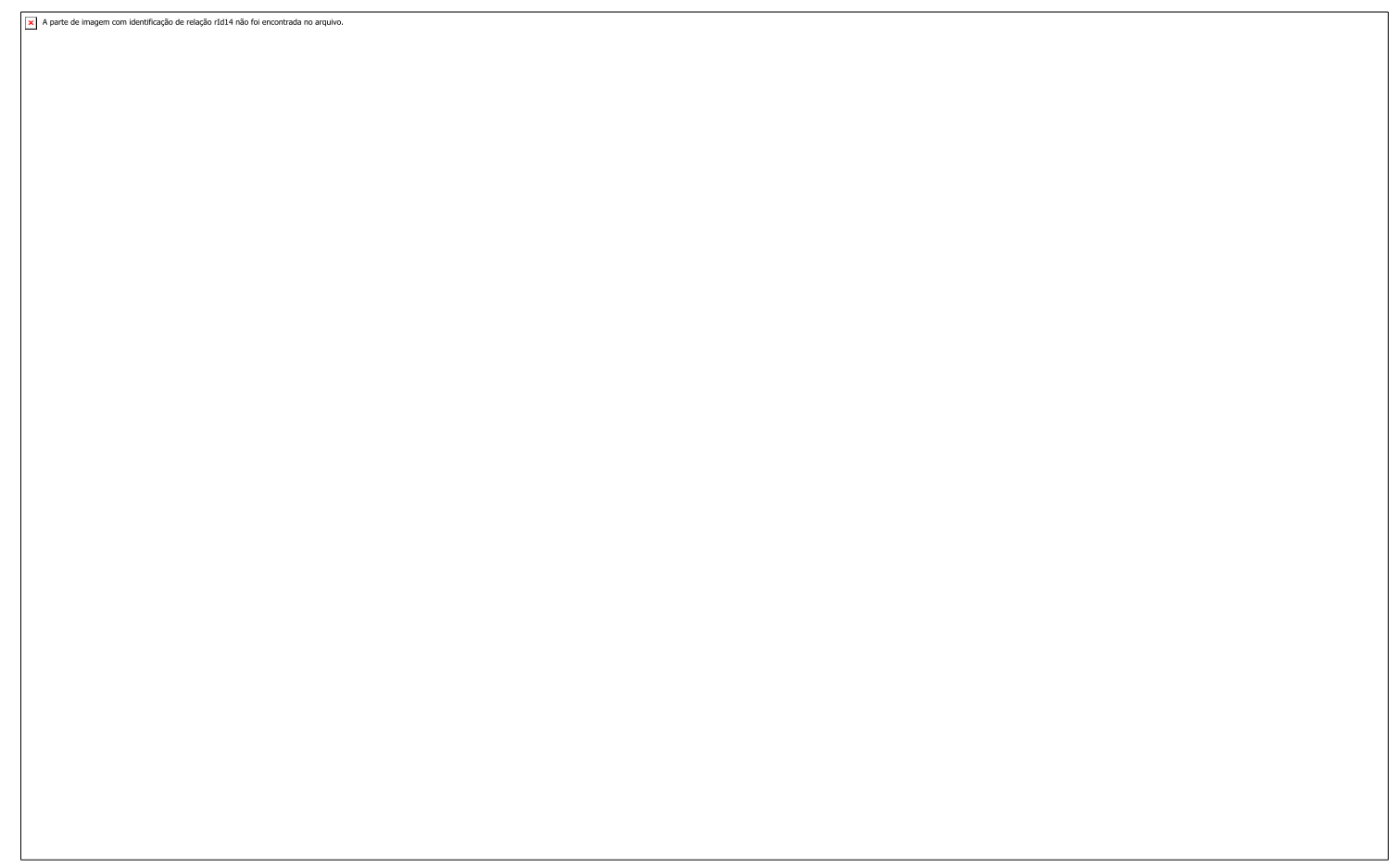

Em Idílio do Amaral. O reino do Congo, os Mbundu (ou Ambundos), o reino dos "Ngola" (ou de Angola) e a presença portuguesa de finais do século XV a meados do século XVI.

A dúvida em relação à data da aparição do título Ngola permanece, bem como em relação à época exata de cada reinado. Mas podemos notar que, por alguma razão, Heintze anulou a presença feminina na sucessão do primeiro Ngola por suas filhas Tunda e Zunda-dia-Ngola, registrada por Cavazzi. Miller também fez questão de apagar os reinados femininos (como veremos a seguir) e segundo suas pesquisas no século XX, Zunda-dia-Ngola seria o nome de um antepassado lendário das linhagens Mbundo do norte que viviam no Médio Lukala, e Tunda-dia-Ngola não representava mais do que um antepassado etiológico dos povos Lenge do Baixo Lukala. ${ }^{53}$

Pretendemos localizar nossa personagem principal, Nzinga Mbandi, na genealogia do título Ngola. A maioria das fontes e interpretações a situam como filha

\footnotetext{
52. Amaral, Idílio. O reino do Congo, os Mbundu (ou Ambundos), o reino dos "Ngola" (ou de Angola) e a presença portuguesa de finais do século XV a meados do século XVI. Lisboa: Ministério da Ciência e da Tecnologia, Instituto de Investigação Científica Tropical, 1996.

${ }^{53}$ Miller. Joseph. Poder político e parentesco. P. 74-76.
} 
legítima de Mbandi Ngola Kiluanji e irmã (ou meia-irmã) de Ngola Mbandi, que assumiu o poder em 1617. Apenas Miller relativiza o sentido de "pai" e "filha" e sugere que este vínculo não era de caráter biológico. Para este autor, Nzinga não pertencia à linhagem real do Ndongo. Veremos adiante como a questão da legitimidade de Nzinga Mbandi foi crucial em determinado momento da história do Ndongo e como foi debatida pela historiografia. 


\subsection{Os Mbundo}

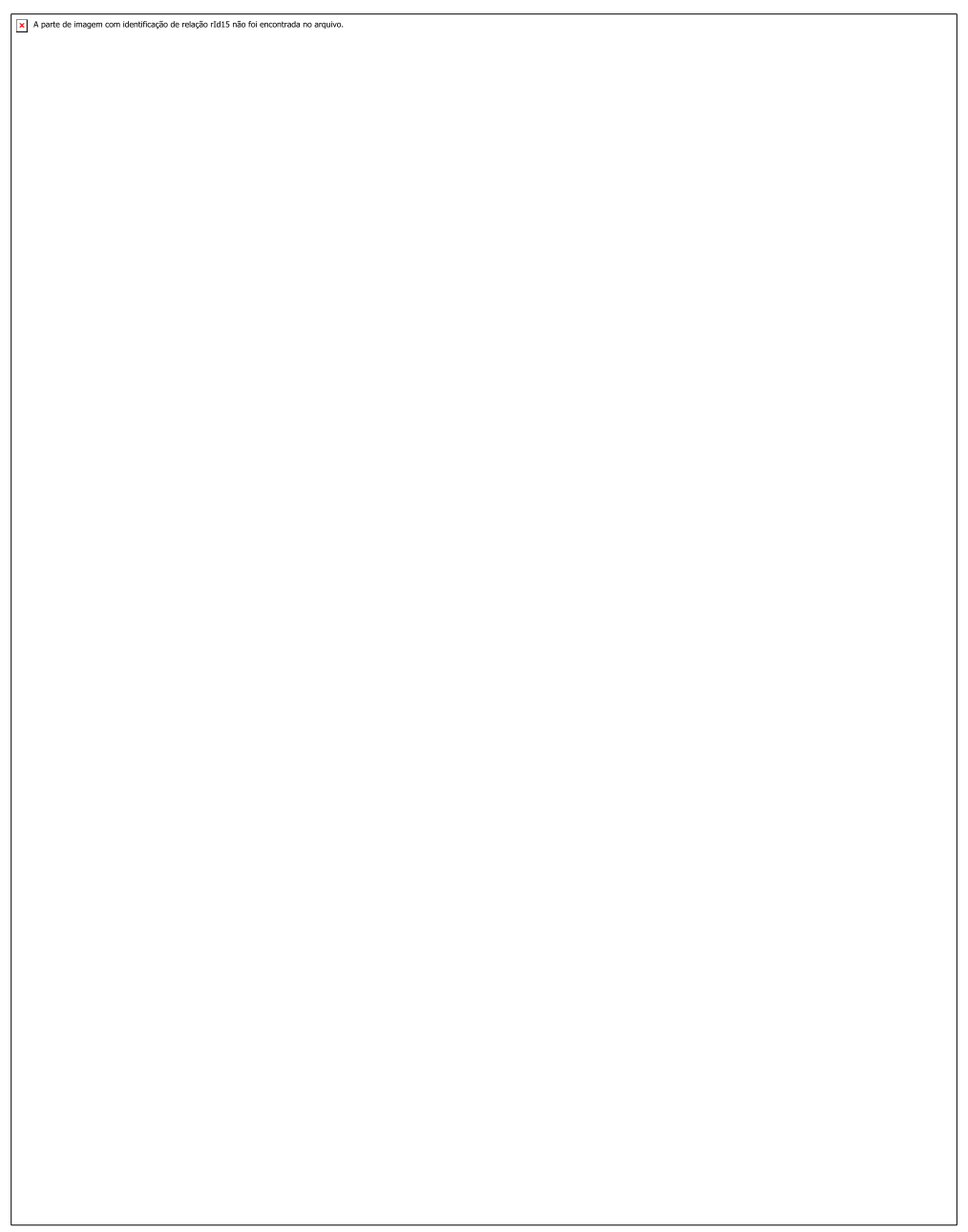

Mapa étnico de Angola em 1970.

Fonte: http://pt.wikipedia.org/wiki/Ficheiro:Angola_Ethnic_map_1970-pt.svg.

Acesso em março de 2012.

Há várias designações para os grupos étnicos de Angola. Para Redinha, o designativo "Mbundo" identifica o grupo étnico Ovimbundo dos planaltos do centro e do sul de Angola, e "Ambundos" designa o grupo étnico que habitava a norte do Planalto de Benguela, sinônimo do grupo étnico-linguístico Kimbundo. ${ }^{54}$ Parreira

\footnotetext{
${ }^{54}$ Redinha, José. Distribuição étnica deAngola, Luanda: Centro de Informação e Turismo de Angola. $8^{a}$ edição. 1974. P. 39. E Etnias e culturas de Angola. Luanda: Instituto de Investigação Científica de Angola, 1975.
} 
chama Ambundos um tipo miscigenado que surgiu nas proximidades de Luanda. ${ }^{55}$ Para Miller e para Childs, Mbundo designa o grupo étnico culturalmente heterogêneo, falante da língua Kimbundo, enquanto que os Ovimbundo localizam-se ao sul e falam o Umbundo. ${ }^{56}$ Neste trabalho, seguimos a nomenclara usada por estes últimos, ou seja, utilizamos Mbundo para designar o extenso grupo etno-linguístico, falantes da língua Kimbundo que habitava as imediações da bacia do rio Kwanza. Chamamos Ovimbundo o grupo etno-linguístico que habita o planalto de Benguela e as vastas regiões do centro e do sul da atual Angola e cuja língua é o Umbundo. Talvez esta aparente discordância seja apenas diferenças de pronuncia da oralidade, reflexo da ausência de normas fixadas para a grafia das línguas centro-africanas.

Os grupos de descendência Mbundo seguiam a sucessão matrilinear e eram formados por um grupo de adultos e pelos filhos de suas irmãs. Cada grupo Mbundo controlava o acesso à terra, recursos econômicos, pesca, produtos florestais e à distribuição de cargos e títulos. A terra era propriedade comum das linhagens e o poder central não intervinha sobre sua ocupação ou uso.

A posição de chefe era geralmente ocupada por um homem idoso, que presidia rituais que favoreciam o bem-estar do grupo. Era considerado um mediador entre os vivos e os antepassados mortos, "que coletivamente representavam a dimensão espiritual de cada título." 57 Usava-se a pemba, pó branco sagrado, para garantir a fertilidade feminina e a reprodução do grupo, e a takula, pó escarnado, também sagrado, utilizado nos rituais masculinos. Havia um conselho de anciãos que coordenavam e assistiam o governo da comunidade.

Os grupos de descendência Mbundo garantiam a integração dos indivíduos na comunidade e a cooperação entre as diversas linhagens. ${ }^{58}$ Eram cobrados impostos sobre a produção agrícola que revelavam a submissão dos territórios subordinados a uma autoridade central. Os chefes que coletavam os impostos pertenciam às linhagens

\footnotetext{
${ }^{55}$ Parreira, Economia e sociedade na época da rainha Ginga. p.167

${ }^{56}$ Miller. Poder político e parentesco. Pp.38-40. E Childs. "The kingdon of Wambo (Huambo):a tentative chronology”. In The Jounal of African History.vol.V,nº3. 1964. Pp.367-379.

${ }^{57}$ Miller. Poder politico e parentesco. pp.46-47.

${ }^{58}$ Idem.Ibdem.p.49.
} 
mais poderosas, que dominavam uma população campesina e organizada em grupos cooperativos de produção comunitária. ${ }^{59}$

Os Mbundo dividiam-se entre murinda (plural arinda) e kijiku (plural ijiku), em que murinda era a população livre, organizada segundo linhagens matrilineares em sobados e kijiku era a população de não-livres, que viviam em aldeias, fora dos sistemas de linhagem dos Mbundo e que constituía, em larga medida, os domínios dinásticos do rei e dos sobas poderosos. A maior parte perdera a liberdade em decorrência de guerras, delitos e crimes considerados graves cuja pena prevista era a escravização. Quando já eram descendentes de $i j u k u$, geralmente não eram vendidos e ao longo das gerações eram integrados na família de seu senhor. Os homens ijiku desempenhavam, quando necessário, o papel de guerreiros, com arcos e flechas e as mulheres trabalhavam no campo. Para o Ngola, todos eram considerados como seus ijiku.

Devemos refletir sobre a estratificação social que existia no reino do Ndongo antes da chegada dos portugueses. A tradução de kijiku por "escravo" implica em alteração do sentido original que a palavra tinha no contexto dos séculos XVI-XVII. Certamente os escravos africanos na América não receberam o mesmo tratamento dispensado aos ijiku no Ndongo, que eram considerados como membros da família do senhor. Frequentemente um kijiku se casava com a filha de seu senhor e assumia posições políticas importantes no sobado.

Thornton apresenta uma definicação de ijiku com grande peso político no contexto Mbundo do final do século XVI e início do XVII, quando os Ngola buscavam centralizar sua autoridade, especialmente pelo uso destes "escravos reais". ${ }^{60}$ Os ijiku teriam garantido o direito à sucessão hereditária de acordo com o desejo do Ngola mais do que com eleição pelos makotas, como tradicionalmente se dava até então. Estes "oficiais escravos" dirigiam negócios na corte e formavam a elite e o corpo oficial do exército real. Mais ainda, os ijiku atuavam como supervisores judiciais e militares sobre

\footnotetext{
${ }^{59}$ Bisson,M.S. "Trade and tribute.Archeological Evidence for the Origin of States in South Central Africa." In Cahiers d'Études Africaine . 1986. Pp343-361. p.344.

${ }^{60}$ Thornton, Jhon. "Legitimacy and Political Power. Queen Njinga, 1624-1663“. The Journal of African History. V.32, n.1, 1991. PP. 29-31.
} 
os territórios dos sobas, representando o poder do Ngola enquanto cobravam as taxas. Este uso dos ijiku aumentou substancialmente as receitas reais e provavelmente permitiu aos governantes criarem redes clientelares entre membros da nobreza. Teria sido este crescimento da poderosa classe de "escravos da corte" que apoiou Nzinga na sua busca pelo poder e na sua luta contra seus rivais sobre o controle dos escravos militares, os kimbares, na década de 1620-30, o que foi determinante nas suas relações com Portugal.

É verdade que a escravidão era uma instituição há muito tempo conhecida na África Central e que já fazia parte da estratificação social dos Mbundo antes da chegada dos europeus. Mas é importante deixar claro que a "escravidão atlântica" foi uma ideia introduzida pelo colonizador português, e alterou profundamente a dinâmica social existente. Sabemos que o tráfico negreiro foi construído junto com atores africanos, que também se favoreceram com a nova ideia de escravidão, em escala comercial atlântica- e que envolveu as elites e transformou o papel das feiras, das guerras, do poder e do homem.

\subsection{Jagas ou Mbangala?}

Quem lê a história de Angola no século XVII inevitavelmente se depara com os Jagas, personagens que desempenharam papéis relevantes e ambíguos, sendo decisivos para muitos episódios. Mas quem eram os Jagas?

O nome Jaga apareceu pela primeira vez na Europa nos relatos de Lopes, publicados por Pigaffeta em $1591 .^{61}$ Aos Jagas é atribuída a culpa pela grande invasão que devastou o reino do Congo em 1568 e expulsou o rei D. Álvaro de sua capital.

Foram descritos como bárbaros, cruéis, canibais, um povo que vivia da guerra, causando destruição das estruturas mais civilizadas da África Central:

"Eles (os Jagas) eram grandes em estatura, mas de uma proporção doentia, e viviam como bestas selvagens, e comiam carne humana. Quando lutavam demonstravam grande coragem, e usavam barulhos pavorosos para assustar os inimigos.",62

\footnotetext{
${ }^{61}$ Lopez, Duarte e Pigaffetta, Filippo. Relação do reino do Congo e das terras circunvizinhas. Comentário e transcrição por Alberto Ferronha. Lisboa: Alfa, 1989. Primeira edição: Relatione del reame di Congo ... Roma.1591
} 
Nota-se que Lopes-Pigaffeta ressaltaram o caráter militar destes grupos, enaltecendo e, por vezes, exagerando suas habilidades enquanto bravos guerreiros. $\mathrm{O}$ que faz todo sentido dentro da organização discursiva da obra destes autores, que pretendiam mostrar o quanto foi importante e essencial o auxílio dado pelos portugueses, comandados pelo Capitão Francisco de Gouvéia, para expulsar os “terríveis” Jagas do Congo em 1569.

O Capuchinho Cavazzi nos deixou uma descrição "quase etnográfica" deste povo que encontrou em Angola no século XVII, que aparece como idêntico aos invasores do Congo. ${ }^{63}$ Apesar de Cavazzi frisar a heterogeneidade dos Jagas, registrou seus mitos, ritos, juramentos, crenças, formas de moradia e alimentação como se fossem únicos para todos os bandos. Como enviado do Vaticano pela Propaganda Fide ${ }^{64}$ para combater as heresias e levar a "verdadeira fé" aos povos gentios, Cavazzi enxergou nos Jagas o próprio diabo cristão e suas práticas religiosas foram traduzidas como "seitas demoníacas". Pensamento este que acompanhou o trabalho missionário na África por longos séculos.

Os Jagas foram personagens frequentes nas diversas fontes do século XVII para a história de Angola. Entendemos que estas fontes do século XVII não se referiam a um grupo étnico específico: as autoridades portuguesas usaram o nome Jaga para designar diversos comandantes de diferentes grupos, mas sempre associadas à guerra, ao nomadismo e à antropofagia. É importante ressaltar que os Jagas não formavam um grupo único e coeso, não compartilhavam um integrado sistema político local. Havia vários bandos de Jagas que se movimentavam e agiam separadamente em diversas rotas, sob o poder exclusivo do chefe de cada Kilombo.

Cavazzi relatou, segundo as tradições que ouviu no tempo que viveu em Angola, que os Jagas teriam vindo de Serra Leoa. ${ }^{65}$ Battel disse que os Jagas que conheceu se originaram na "serra de leão". Uma confusão na tradução deste texto teria reforçado esta

\footnotetext{
${ }^{62}$ Idem. Op. Cit. p. 135.

${ }^{63}$ Cavazzi. Giovanni Antonio. Descrição histórica dos três reinos do Congo, Matamba e Angola. 2 volumes. Lisboa : Junta de Investigações do Ultramar, 1965.

${ }^{64}$ Congregação de Propaganda Fide, criada em 1622 pelo Papa Gregório XV para dirigir e coordenar toda a atividade missionária da Igreja, procurando torná-la independente da tutela das potências coloniais católicas da época, em particular Espanha e Portugal. Ver: www. fides.org (acesso em fevereiro de 2012)

${ }^{65}$ Cavazzi, Op. Cit. Vol I. p. 34 e seguintes.
} 
origem em Serra Leoa, mas provavelmente trata-se de uma referência a Kinguri, um líder cujo nome deriva de nguri, que quer dizer leão.

\section{Temba Ndumba e o Magi a Samba: ritos e costumes Jagas}

Cavazzi narrou as origens fundadoras deste bando guerreiro em que um grande chefe chamado Zimbo percorreu vasta área da África Central destruindo povoações e conclamando guerreiros para acompanhá-lo. Sua filha, chamada Temba Ndumba, a fim de tornar seus soldados invencíveis realizou um ritual chamado Magi a Samba, em que lançou seu filho recém-nascido num caldeirão e com um pilão esmagou a criança até reduzi-la a uma pasta, à qual acrescentou algumas ervas e raízes. Este ungüento foi passado no corpo dos guerreiros para lhes dar forças mágicas e imortalidade. O bando conclamou Temba Ndumba como líder do bando e passou a seguir severamente as leis Kijilas, que significa proibição na língua Kimbundo.

Miller estudou a sociedade Mbangala, descendente do bando de Kulaxingo, identificado como o poderoso Jaga Cassanje da documentação do século XVII. Ao analisar as insígnias de poder e organização política dos Mbangala, percebeu que o assassinato de crianças, representado pelo ritual Magi a Samba, era uma forma de romper os laços de linhagem que dominavam a sociedade Mbundo. Da mesma forma, o rapto de jovens não iniciados, que garantia continuidade do grupo, servia ao propósito de se desprender das regras e costumes do grupo de origem e prestar obediência exclusiva ao chefe do Kilombo e não mais aos mais velhos da linhagem e aos detentores das insígnias de onde nasceram. Assim conseguiram se libertar do sistema de linhagens, tão importantes no universo Mbundo daquele tempo, e fundar uma nova sociedade com rituais próprios de iniciação e de entronização do poder, em que a obediência ao chefe do Kilombo e a guerra eram elementos fundamentais.

Vansina notou que a prática de matar as crianças recém-nascidas possibilitou a maior mobilidade das tropas, que viviam em estado permanente de guerra, uma vez que bebês representavam um empecilho ao deslocamento dos exércitos. ${ }^{66}$ Assim o infanticídio representou uma inovação que possibilitou o progresso militar dos Jagas.

\footnotetext{
${ }^{66}$ Vansina. How societies are born. P. 199.
} 
A organização no Kilombo, enquanto sociedade nômade guerreira, foi essencial para a atuação destes guerreiros. Kilombo designava entre os Ovimbundos (etnia ao sul do Kwanza) uma instituição destinada ao treinamento de meninos para os ritos de passagem para a vida adulta, ou campo de circuncisão, de caráter primordialmente masculino, em que os iniciados aprendiam táticas de ataque e defesa militar.

Os makotas vindos da Lunda, após assassinarem (ou abolirem) o título do Kinguri, adotaram a organização do Kilombo e a estruturaram para atender seus desígnios de guerra. Os guerreiros no Kilombo recebiam treinamento miliar intensivo, aprendiam manejar armas próprias destes grupos, como machadinhas, lanças e grandes escudos e, principalmente, aprendiam a ter obediência incondicional ao chefe do Kilombo. Concordamos com a ideia proposta por Miller de "Kilombo enquanto máquina de guerra". ${ }^{67}$

O Kilombo era uma organização altamente hierarquizada, em que cada guerreiro tinha funções e lugares específicos e bem definidos. Os grupos se organizavam em unidades militares lideradas por capitães que seguiam o comando de um único líder, o chefe do Kilombo. Este era um líder carismático cuja atração foi enraizada por sua coragem e seus sucessos nas batalhas, um sucesso atribuído a seus poderes extraordinários sobrenaturais como adivinhador do futuro e como receptor do apoio inquestionável por parte de seus predecessores mortos, os ancestrais. ${ }^{68}$ Esta sociedade adotou um modo de vida errante e transportava caixas que continham os ossos de seus líderes antepassados, considerados sagrados.

Cavazzi descreveu e desenhou esquematicamente a estruturação do Kilombo, em que os diversos níveis de paliçada impediam que as pessoas chegassem perto do chefe, que tinha seu mocano estrategicamente inacessível e vigiado.

\footnotetext{
${ }^{67}$ Miller. Poder politico e parentesco. Capítulo 05.

${ }^{68}$ Vansina. How societies are born. P. 201.
} 


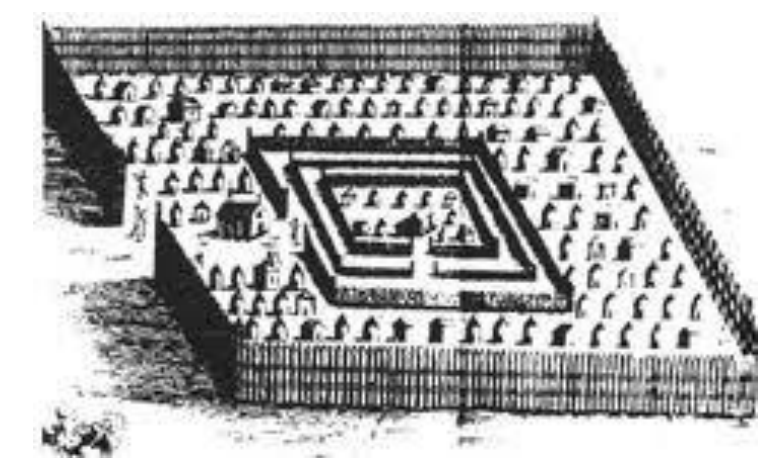

Representação de um Kilombo. Em Cavazzi. Vol. I.p.182

A regulação interna destas comunidades repousava em um conjunto de rigorosas regras e na obediência inquestionada a seus líderes. Para Vansina não há dúvidas que a rígida crueldade e desumanidade de sua organização interna foi responsável pela sobrevivência por mais de um século desta sociedade baseada em princípios predatórios tão extremos. ${ }^{69}$

Na análise de Vansina, a economia Jaga era totalmente predatória: outras sociedades produziam, eles consumiam. Eles imitavam os padrões de consumo dos ricos, "farreando e festejando" sem a preservação dos recursos para o futuro: matavam as palmeiras de onde tiravam o vinho, consumiam o rebanho ao invés de cria-lo, roubavam o milho de outros e não sabiam nada sobre armazenagem de alimentos. Vansina associa os Jagas aos anarquistas, por rejeitarem a vida sedentária e organizada pela produção agropecuária dos Mbundo, principais vítimas de suas rapinas. ${ }^{70}$ Esta interpretação não nos parece adequada, pois os anarquistas não rejeitavam a vida sedentária e organizada, defendiam o auto-governo, que em absoluto, era o padrão dos Jagas, onde as lideranças tinham lugares bem evidentes.

Não sabemos ainda como ou porque a migração Jaga ocorreu. Vansina a associa à chegada dos primeiros traficantes de escravos e analisa o surgimento dos Jagas no contexto da desigualdade social existente entre ricos e pobres, que fora também explorada no processo de implantação do tráfico de escravos. Ao encontrar novos seguidores, os bandos Jagas se tornaram a expressão da revolta dos que não tinham contra os que tinham. Os ricos controlavam os meios de produção agropastoris e as

\footnotetext{
${ }^{69}$ Vansina.How societies are born. P. 199.

${ }^{70}$ Vansina.How societies are born. P. 200
} 
ferramentas mais necessárias, como as enxadas, enquanto os pobres sobreviviam apenas como serventes pela graça do rico e do poderoso. Quando os traficantes de escravos portugueses apareceram na costa, este povo pobre era o que corria mais risco de ser vendido como escravo. Na medida em que se tornaram potentes guerreiros Jagas, conseguiam se manter livres e passaram a ser eles que vendiam os outros como escravos, atuando como os ricos, como uma revanche, no olhar de Vansina. ${ }^{71}$

\section{Jagas ou Mbangala? Criação das fontes e negação da historiografia}

Além do papel decisivo e ambíguo que desempenharam na história de Angola, os Jagas tornaram-se objeto da historiografia devido a incertezas de sua identidade. Estudos recentes demonstraram que os descendentes de Cassanje, os atuais Mbangala do distrito de Malanje, foram chamados de Jagas no século XVII. ${ }^{72}$ A partir daí, alguns historiadores passaram a substituir a palavra "Jaga" por "Mbangala", como se fossem sinônimos. ${ }^{73}$ Esta opção esconde a heterogeneidade dos Jagas, que não eram um grupo único. Vários bandos de origens distintas foram chamados de Jagas pelos portugueses e nossa intenção foi entender quem eram estes Jagas das fontes do século XVII.

A historiografia começou a se interessar pelos Jagas-Mbangala e investigar suas origens a partir de 1963, quando o Journal of African History passou a publicar uma série de artigosque elucidaram o processo de formação dos reinos da África Central. Jan Vansina $^{74}$ foi o precursor destes estudos e inaugurou um método a partir das tradições orais publicadas sobre a origem dos povos Mbangala, quem foram identificados aos Jagas das fontes do século XVII.

Vansina recorreu à tradição oral publicada por Henrique de Carvalho ${ }^{75}$ sobre a migração de Kinguri, filho do chefe Lunda Yala Mwaka, que após perder o poder para o

\footnotetext{
${ }^{71}$ Idem. P. 201.

${ }^{72}$ Vansina. The Foundation of the Kingdom of Kasanje. The Journal of African History. Vol. 4, No. 3 (1963), pp. 355-374. E Miller. Poder politico e parentesco.

${ }^{73}$ Birmingham, David. The Date and Significance of the Imbangala Invasion of Angola.The Journal of African History, Vol. 6, No. 2 (1965), pp. 143-152.

${ }^{74}$ Vansina. The Foundation of the Kingdom of Kasanje. The Journal of African History. Vol. 4, No. 3 (1963), pp. 355-374.

${ }^{75}$ Carvalho, H. Dias de .o Jagado de Cassange. Lisboa, I890.
} 
cunhado Luba, Kibinda Ilunga, foi para a região da Angola portuguesa onde ofereceu seus serviços a um governador chamado Manuel, que usou os imigrantes como tropas auxiliares para lutar contra o Ngola.

Vansina comparou a versão de H. Carvalho com outras versões publicadas sobre a origem dos Mbangala, como a narrativa publicada por Neves, ${ }^{76}$ as versões Lunda, tradições dos Pendes, Ovimbumdu, Sala Mpasu e Cokwe. Utilizou apenas narrativas publicadas por europeus que foram à África Central, principalmente no século XIX. A partir destas tradições, Vansina reconstruiu a história da fundação do reino de Cassanje (que ele chamou Kasanje) e as datas em que ocorreram as principais migrações. Concluiu que aproximadamente em 1600, um grupo da Lunda deixou o país sob o comando de Kinguri. Eles haviam migrado devido à tomada de poder Luba daquele país. Primeiramente, eles se fixaram nos altos platôs onde o Kwango e o Kasai tem suas nascentes, mas foram expulsos por uma segunda onda migratória vinda da Lunda, composta majoritariamente por Cokwe. Foram dirigidos para o oeste e chegaram no país Songo perto de Bola Cassache. Ali Kinguri morreu, sucedendo-lhe Kasanje, que se dizia seu sobrinho.

Os Lunda e seus aliados locais se autodenominavam como Mbangala, apesar das fontes do século XVII terem sempre chamado Cassanje de Jaga. Vansina pensa que neste momento histórico, o grupo da Lunda foi absorvido por bandos Jagas, que estavam no Ndongo desde 1594 ou até mesmo antes da invasão do Congo.

Henrique de Carvalho explicou que o título Jaga foi dado a Quinguri (Kinguri) pelo capitão-general que o recebeu, "por isso que então os principaes potentados dos povos que fomos encontrando nas terras que íamos conquistando, estes lhes davam taes títulos ou porque realmente lhes pertenciam ou por imitarem o que era d'outros povos." ${ }^{, 77}$ Só depois da união das três famílias Culaxingo (Quinguri, Lunda), Ngonga (Libolo) e Calunga (Jinga) que se formou o estado que recebeu o nome de Cassanje, que seria um neto de Quinguri que fundou o "jagado". A tradição recolhida por Carvalho conta que antigamente, na região de Ambaca, se via uns meirinhos que andavam com grande paus como símbolo da autoridade, que usavam quando iam cobrar impostos e a

\footnotetext{
${ }^{76}$ Neves. Memória da Expedição a Cassange. Lisboa, 1854.

${ }^{77}$ Carvalho, H. Dias de. O Jagado de Cassange. P.31. Preservamos a grafia utilizada pelos autores, pois não temos ferramentas que sustentem a opção por Kinguri ou por Quinguri.
} 
esses paus chamavam bangalas, e por esta alcunha os portugueses passaram a lhes chamar. $^{78}$

Miller disse que os portugueses concederam a Kulaxingo- que fizera reviver os poderes de kinguri- o título Jaga, "uma honra de sua própria invenção", e lhe deram o nome Cassanje em reconhecimento ao título Kasanje que ele tinha usado na época dos primeiros contatos com eles. Assim "Jaga Cassanje" tornou-se a designação oficial portuguesa para todos os posteriores reis do bando dos Mbangalas de Kulaxingo, e os seus próprios seguidores foram conhecidos como "Cassanjes.", 79

David Birmingham defendeu que o encontro dos Mbangala com os portugueses ocorreu no do século XVI, afirmando que em 1575, se não antes, os Mbangala que invadiram Angola vindos da Lunda, já tinham atingido o mar em Luanda e feito contato com os portugueses. ${ }^{80}$ Suas afirmações basearam-se em documentos que narram a luta de Paulo Dias de Novais contra Mani Kasanje, que tentou impedir que o primeiro governador se estabelecesse na ilha principal de Luanda. Birmingham fala de um pequeno estado entre Luanda e o rio Bengo, chamado pelos portugueses de Nsaka de Kasanje, que persistiu até 1622 , quando foi continuamente pilhado pelas caravanas e finalmente destruído pelo governador que executou o chefe Kasanje e deportou os seus para o Brasil. ${ }^{81}$ Assim, Birmingham concluiu que Kasanje já estava em Luanda em 1575 .

Grave erro cometeu este historiador, que deveria estar sempre atento às homografias tão presentes nas histórias da África Central. Vansina ${ }^{82}$ corrigiu o colega, demonstrando que o Kasanje que havia na Nsaka em 1575 não era o mesmo Kasanje das tradições Lunda. O Kasanje da Nsaka era um tributário do mani Bamba e seu povo era Congo. Vansina argumentou que eventos em 1622 deixam bem claro que eram dois "Kasanjes", quando o governador de Angola destruiu Nsaka, matando e prendendo os membros da família do chefe. No mesmo ano, o rei do Ndongo e o governador de Angola firmaram um acordo de cessar-fogos em que a maior condição era que os

\footnotetext{
${ }^{78}$ Idem. Pp.31-34.

${ }^{79}$ Miller. Poder politico e parentesco. P.189.

${ }^{80}$ Birmingham, David. The Date and Significance of the Imbangala Invasion of Angola.The Journal of African History, Vol. 6, No. 2 (1965), pp. 143-152.

${ }^{81}$ Carta de João Correia de Souza para o Marques de Frencha, 3/6/1622. Brásio. Vol. VII, p. 17-24

${ }^{82}$ Vansina, Jan. More on the Invasions of Kongo and Angola by the Jaga and the Lunda The Journal of African History, Vol. 7, No. 3 (1966), pp. 421-429.
} 
portugueses poderiam atacar Kasanje que estava atormentando o Ngola. Este não pode ter sido o Kasanje que foi totalmente destruído. O Jaga Kasanje estava vivo nesta época a leste do Ngola, e o mani Kasanje da Nsaka vivia a Oeste, antes de ser assassinado. ${ }^{83}$ Para melhor diferenciar, Heintze adotou a ortografia de Henrique de Carvalho, chamando o Jaga de Cassanje e o mani da Nsaka de Casanze. ${ }^{84}$

Neste mesmo artigo, Vansina continuou o debate sobre Jagas-Mbangala falando dos dois grandes movimentos migratórios ocorridos em Angola no século XVI: o dos Jagas, que culminou com a entrada na capital do reino do Congo em 1568, e o dos Lunda, ainda menos estudado e conhecido, sobretudo porque este grande movimento migratório se subdividiu em várias submigrações. ${ }^{85}$ Defendeu que os primeiros contatos dos sucessores de Kinguri com os portugueses teriam ocorrido por volta de 1610, o que dá um intervalo suficiente da chegada dos Jagas. Para o autor, ambas invasões estiveram envolvidas e a relação entre elas precisa ser melhor investigada. Após a campanha militar de Francisco de Gouveia, que expulsou os Jagas do Congo em 1569, alguns grupos teriam migrado para o vale do Kwango e para Angola. ${ }^{86}$

Hoje parece consenso entre os historiadores de Angola que os chamados Jagas que estavam nas imediações do Kwanza no século XVII não eram os mesmos que invadiram o Congo. Vansina tentou encerrar a questão citando Abreu de Brito, que afirmou em 1591 serem dois povos distintos. ${ }^{87}$ Mas devemos supor que estes bandos que desceram do Congo em direção a Angola no final do século XVI se integraram a outros fluxos migratórios. Sendo os ditos Jagas bandos tão heterogêneos, podemos imaginar que muitos deles fizeram parte da invasão do Congo e, ao fugirem para Angola adotaram novas instituições militares, como a do kilombo e ganharam uma nova identidade. A repetição do nome Jaga pelos portugueses no século XVII sugere proximidade entre o modo de viver de ambos os povos migrantes que convergiram em Angola neste período e não podemos ignorar a semelhança que havia entre eles, já que a designação foi mantida.

\footnotetext{
${ }^{83}$ Brásio. Vol. IX, p.8; vol.III, p. 571, vol. VII, p. 27. e Felner.Angola. P. 117 e 212-13.

${ }^{84}$ Heintze, B. Angola nos séculos XVI e XVII. P.284. nota 28.

${ }^{85}$ Vansina, Jan. More on the Invasions of Kongo and Angola by the Jaga and the Lunda. The Journal of African History, Vol. 7, No. 3 (1966), pp. 421-429.

${ }^{86}$ Brásio. Vol. IV. P. 533

${ }^{87}$ Vansina.How societies are born.p.202.
} 
O comerciante inglês Andrew Battel reportou, por volta de 1601, que os Jagas que ele conheceu em Benguela Velha, pertencentes ao bando de Kalandula, chamavamse a si próprios de Imbangola. ${ }^{8}$

Problematizamos: como os descendentes da Lunda tomaram o nome Jaga? Vansina questiona por que os Jagas, que até então tinham sempre incorporado outros povos, teriam agora se deixado incorporar pelos Lunda? E por que o Cassanje foi chamado de Jaga por Cavazzi, Cardonega e pelas fontes administrativas, significando o rei dos Jagas? Vansina levanta duas explicações possíveis: uma diz que o Kasanje que sucedeu Kinguri era um Jaga, e que a filiação foi feita depois; outra é que Jaga e Lunda eram intimamente relacionados e que eles se sentiam parte de uma mesma cultura. Não há dúvidas que os Lunda tomaram o nome Jaga "Imbangola" e rapidamente estabeleceram a reputação de serem os mais genuínos Jagas. Em Cavazzi, os nomes Kasanje, Kulashingo e Kinguri aparecem, o que nos remete para a presença deles no século XVII, reforçando a hipótese de que neste contexto Jaga e Mbagala eram profundamente misturados.

\footnotetext{
${ }^{88}$ Ravestein, E. (org.) The strange adventures of Andrew Battel pf Leigh in Angola and the Adjoining regions. London : The Hakluyt Society ,1901.
} 


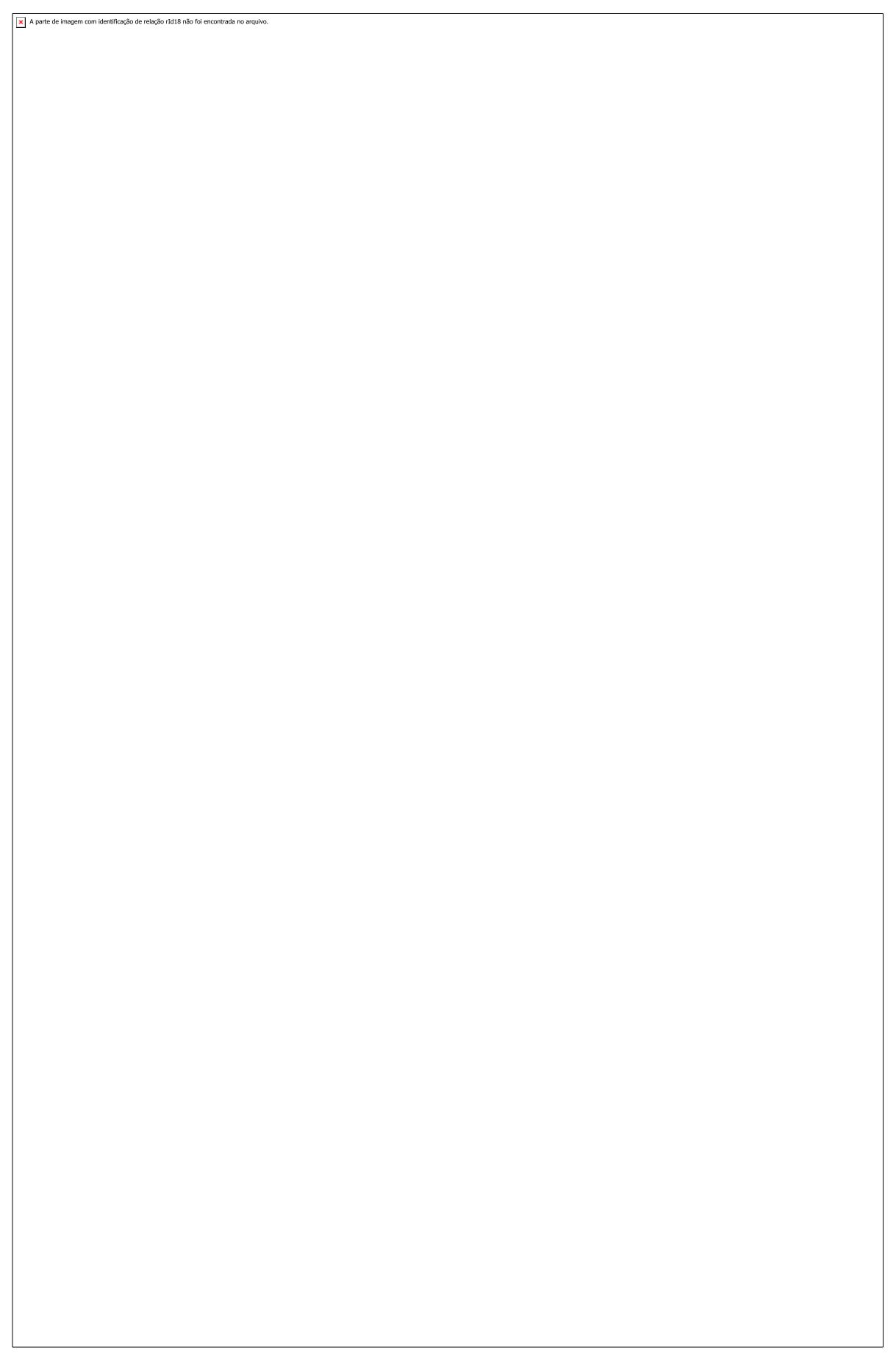

Em Heintze, Angola nos séculos XVI e XVII. p.41

De acordo com os estudos de Vansina, os Jagas chegaram a Angola em 1569 e os Lunda em torno de $1600 .{ }^{89}$ Ambos iniciaram grandes invasões, em que a dos Jagas foi mais do tipo conquistador, com uma organização predatória, enquanto que a dos Lunda parece ter confiado menos na conquista e mais no prestígio de governar todos os

${ }^{89}$ Vansina, Jan. More on the Invasions of Kongo and Angola by the Jaga and the Lunda The Journal of African History, Vol. 7, No. 3 (1966), pp. 421-429. 
povos que eles encontravam a leste do Kwango. Ambas as invasões parecem ter se originado da mesma área geral da África Central e estão ligadas à invasão Luba sobre a Lunda. Vansina termina este artigo incitando os pesquisadores a realizarem mais trabalhos de campo para esclarecer as relações entre as estruturas e tradições Mbangala e o crescimento e expansão do sistema político Luba.

Miller seguiu a dica de seu orientador e na década de 1970 foi ao atual distrito de Malanje investigar as origens do povo Mbangala, descendentes de Cassanje. Os resultados de sua pesquisa foram publicados em Poder político e parentesco ${ }^{90}$ e em um artigo que dá continuidade ao debate acimamencionado. ${ }^{91}$ Miller alterou profundamente a compreensão das cronologias Mbangala, ao revelar que os nomes que aparecem nas genealogias representam posições políticas permanentes e não indivíduos. Assim Kinguri, Lueji, Kasanje, etc são títulos e não personagens históricas definidas. Miller decifrou as metáforas embutidas nas tradições, em que casamentos representam a união do título masculino e as figuras femininas que simbolizavam grupos das matrilinhagens. A morte significa a abolição de um título e não de uma pessoa, assim quando os makotas Lunda matam Kinguri simboliza que seus súditos ritualmente aboliram a posição titular de seu rei. Sobre o método de interpretação das tradições, Miller nos alerta que as tradições orais são seletivas e retém apenas o que lhes interessa legitimar, assim as tradições de cada grupo étnico, incluindo os Mbangala, lembra apenas os eventos que afetaram a seu próprio sistema político durante o movimento do título Kinguri da Lunda para Angola, o que não fora levado em conta pela historiografia anterior.

De acordo com as tradições Mbangala que Miller recolheu, o bando de Kinguri assimilou muitos novos títulos e posições dos Cokwe/Lwena. Os reinos Kulembe e Libolo bloquearam o movimento de Kinguri para o Kwanza, levando-o a se fixar outra vez e fundar um segundo reino, desta vez junto aos Songo que viviam nos rios Luhando e Jumbo. A complexidade do desenvolvimento político que ocorreu ali implica que

\footnotetext{
${ }^{90}$ Miller, Joseph. Poder político e parentesco: os antigos estados Mbundu em Angola. Trad. De Maria da Conceição Neto. Luanda: Arquivo Histórico Nacional, 1995. Título original: Kings and Kinsmen: early Mbundu States in Angola. Oxford: Claredon Press, 1976.

${ }^{91}$ Miller, Joseph. The Imbangala anfd the cronology of Early Central African History. The Journal of African History, Vol. 13, n.4, 1972.
} 
Kinguri permaneceu entre os Songo por um considerável período. As tradições Songo relatam vários casamentos metafóricos entre o título Kinguri e figuras femininas que simbolizavam grupos das matrilinhagens Songo. Como estes casamentos produziram várias posições titulares Songo descendentes do Kinguri, indicam a criação de um reino extenso, um processo que deve ter se estendido por muitas décadas.

Os Lundas converteram-se em guerreiros Mbangala quando os makotas que sucederam na abolição do título Kinguri adotaram o Kilombo, em prol de um sistema político diferente baseado em instituições dos Kulembe e do Libolo. O Kinguri nas diversas narrativas é descrito como um chefe cruel e sanguinário, que toda vez que se levantava cravava lanças em dois de seus súditos, um clichê que aparece em diversas narrativas de reis da África Central. As tradições narram o episódio em que os makotas decidem matar Kinguri, pois sua tirania estava acabando com seu próprio povo. Os makotas se separaram de Kinguri logo após os Lunda terem se dispersado entre os Songo, numa ilha no alto Kwanza conhecida como Mbola na Kasashe. Os makotas Lunda encontraram no Kilombo um efetivo método para combater Kiguri e então realizaram os rituais necessários para a abolição do título.

O nome Kilombo veio dos Ovimbundos, onde designa a sociedade de iniciação masculina a que pertenciam os guerreiros de Kulembe e foi adotada pelos migrantes da Luanda, que a partir daí se denominaram Mbangala. ${ }^{92}$ Segundo Cavazzi, Kulembe era o marido de Temba Ndumba, que após sua morte, assumiu o controle de uma sociedade de iniciação guerreira chamada Kilombo. Kulembe e seus kilombos entraram numa fase de grande expansão sob a liderança de generais chamados Calanda, Cete, Cassa, Cabuco, Caiomba e muitos outros. ${ }^{93}$ Miller encontrou correspondências destes títulos nas tradições Mbangala: Calanda era Kalanda Ka Imbe, Cabuco era Kabuco ka Ndonga, um título subordinado ao Ndonga. Cassa parece ter origem em outro lugar, provavelmente no Libolo onde consta um titulo Kasa Ka Hango, mas sabe-se que ele esteve próximo aos makotas Lunda e mais tarde tornou-se importante em Cassanje.

\footnotetext{
${ }^{92}$ Miller, Joseph. Poder político e parentesco. P. 132 e seguintes.

${ }^{93}$ Cavazzi. Descrição histórica dos três reinos do Congo, Matamba e Angola. Lisboa: Junta de Investigações do Ultramar, 1965 . Vol.I. p. 189 e seguintes.
} 
A questão que hoje se levanta é: por que as fontes não registraram este povo com o nome de Mbangala, optando por chamá-los de Jagas? Birmingham e Miller concordam que a primeira referência documental aos Mbangala foi em 1563, na carta do jesuíta que acompanhou o primeiro donatário Paulo Dias de Novais, ${ }^{94}$ que escreveu que os exércitos de Ngola a Kiluanje tinha feito uma série de guerras no interior contra o "rei de Banguela". Birmingham afirma que o referido rei era Kinguri-Kya-Bangela. Miller já acredita que se refere a um dos makotas Lunda que sucederam Kinguri e sugere que problemas lingüísticos na tradução podem ter levado a confusão com a Baía de Benguela, ao sul de Angola. Miller argumenta que o termo Mbangala era estrangeiro tanto para o jesuíta que escreveu o documento quanto para o Kimbundo que provavelmente lhe transmitiu a informação. Os falantes do português costumam omitir a primeira vogal das palavras banto, assim um escritor português em 1560 poderia muito bem ter escrito 'banguela' ao invés de Mbangala ou Imbangala.

Vansina refuta Birmingham alegando que o Kinguri Kya Benguela não poderia ser o "rei de Banguela" mencionado como tributário do rei de Angola na documentação, pois Benguela não fora ocupada antes de 1601. No tempo de Battell, o Jaga Kalandula estava justamente atacando o território ao sul do Kwanza. O dito rei de Benguela foi sucedido em 1563 por dois de seus filhos que se rebelaram contra o Ngola, enquanto a tradição é enfática que Kinguri foi sucedido por uma única pessoa, Kasanje Ka Imba. Há aqui mais um caso de homografia, em que Kiguri aparece também como nome e como título no reino do Congo.

Se esta única referência diz respeito a um chefe Mbangala ou não, dificilmente resolveremos, mas a ausência do nome Mbangala na documentação do século XVII é por si importante. As fontes constantemente falam de Jagas, tanto do lado dos portugueses, como de Nzinga Mbandi. Miller, repetidas vezes, diz que as fontes erram ao chamarem os Mbangala de Jagas. Acreditamos ser pretensão do historiador moderno dizer que as fontes erraram. No contexto do século XVII a identidade dos Jagas com os Mbangala devia ser grande para levar aos autores das diversas fontes chamarem todos de Jagas.

\footnotetext{
${ }^{94}$ Carta do irmão António Mendes para o Padre Geral, 9/5/1563. Brásio. Vol. II. P. 509
} 
Miller manifestou sua intenção de abolir a noção de Jaga da historiografia da África Central como sinônimo de uma entidade etno-cultural definida. Já pelo título do artigo "Réquiem for the Jaga" ${ }^{95}$, Miller sugeriu a eliminação deste grupo da história da região, ao afirmar que os Jagas nunca existiram fora da imaginação dos missionários, traficantes de escravos ou dos oficiais do governo português, que criaram estes míticos canibais para justificar suas próprias atividades na África. Os europeus enxergavam a crueldade, canibalismo e barbárie em vários povos africanos e acabaram dando a todos o nome de "Jaga", somando-se a noções imprecisas da geografia africana nos séculos XVI e XVII. Erros etimológicos teriam estimulado a falsa associação entre Jaga, Agagi, Galas. As características físicas dos Jagas e seus comportamentos, como foram descritos, contrariava todas as coisas que eram familiares aos europeus: eram negros, monstruosos, canibais e destruíam toda e qualquer forma de civilização, assim desempenharam a mesma função que as Amazonas na mitologia européia, como uma oposição aos valores "civilizados". Alguns detalhes da aparência e armamento dos Jagas derivavam do generalizado estereotipo do selvagem africano.

Na visão de Miller, o alegado apetite por carne humana recebeu especial atenção dos traficantes de escravos em Angola. Mercadores privados e públicos os usaram para defender a moralidade do tráfico, pois a escravização livraria os povos Mbundo de serem comidos pelos Jagas. ${ }^{96}$ Traficantes também os evocaram para explicar as diferenças entre o número de prisioneiros feitos no interior e o número de escravos exportados no litoral. Os escravos faltantes, é claro, foram exportados ilegalmente, sem pagar os tributos devidos, mas os traficantes ilícitos explicaram esta discrepância alegando que teriam sido comidos pelos Jagas. Miller, ao se aprofundar na história do Congo, conclui que a dita invasão de 1568 fora uma colisão de descontentes internos que assolaram o poder, somados a invasores externos de outros reinos vizinhos. Para Miller, a criação do "mito dos Jagas" serviu bem aos propósitos portugueses, pois após o resgate de D. Álvaro, Portugal passou exigir soberania daquele reino.

\footnotetext{
${ }^{95}$ Miller, Joseph. "Requiem for the Jaga.”Cahiers d'Etudes Africaines, v. 13, n.49.p.121-149, 1973.

${ }^{96}$ Miller, Joseph. "Requiem for the Jaga". P.124.
} 
John Thornton deu continuidade ao debate ao "ressuscitar" os Jagas, afirmando a existência histórica deste grupo, contrapondo-se a Miller ${ }^{97}$. Identificou-os aos Yakas do Vale do Niari, que de fato, invadiram o Congo. Thornton concluiu que o nome Jaga descreve mais um modo de vida do que um grupo étnico específico.

François Bontick ${ }^{98}$ e Anne Hilton ${ }^{99}$ também deram sua contribuição para este debate, ambos adentrando-se na história do Congo para identificarem quem foram os Jagas. Para determinar a identidade dos invasores de 1568, Hilton buscou compreender os contextos em que o povo Congo usava o termo "Jaga". Hilton encontrou quatro sentidos:

1) Era usado em amplo sentido como o outro (aka), como estrangeiro

2) Designava o povo que viva ao norte do rio Zaire, os quais eram considerados pelos povos do sul como forasteiros. Na metade do século XVII, o padre Girolamo da Montesarchio escreveu ao padre Boaventura da Sorento comentando sobre as terras "do povo mais feroz que come carne humana eram chamados Giacas." ${ }^{100}$ Indubitavelmente estes povos tinham a cultura e a língua Tio, diferente do Congo. Os Congoleses os chamavam "Jaga" no sentido geral de forasteiros e invasores.

3) Designava os Mbangala, bandos militares sem linhagens que tinham se envolvido em guerras contra os Mbundos do sul. Assim como os "Jagas" do norte do Zaire, os Mbangala eram etnicamente distintos e invasores. Na metade do século XVII, Garcia II empregou um Jaga chamado Kabuko para governar um acampamento de escravos refugiados perto de Mbanza Kongo.

4) Designava povos a leste do Kongo dia Nlaza, que deixou um exército que incluíam povos chamados Majacas, ferozes como os Jagas. Cardonega incluiu os Majacas entre os Jagas.

\footnotetext{
${ }^{97}$ Thornton, John. « A ressurection for the Jaga». Cahiers d'Études Africaines, v.18, n 69, p. 223-227. 1978.

${ }^{98}$ Bontinck,François. «Un mausolée por les Jaga.» Cahiers d'Etudes Africaines, v 20, n.79. p. 387-389. 1980

${ }_{99}^{19}$ Hilton, Anne. "The Jaga reconsidered”. The Journal of African History.Vol.22.n.2 (1981)pp.191-202. Cambridge University Press.

${ }^{100}$ Padre Girolamo da Montesarchio para padre Bonaventura da Sorrento, 23 de março de 1650, Nsevo, Nsundi. Em Brásio. vol. VII. P.486.
} 
Anne Hilton sugeriu que os Jagas que invadiram o Congo eram os ancestrais dos Muyaka do século XVII, que roubavam os escravos do mercado de Makoko. Estes Jagas que atacaram o Congo não são os mesmos que as fontes do século XVII em Angola se referem. Aceitamos a hipótese de que após o retorno ao trono do maniCongo pelas tropas de Francisco Gouveia, alguns bandos de Jagas expulsos atravessaram o Kwango e adentraram no território do Ngola. Os sucessivos processos de incorporação de povos de outras etnias nos faz crer que se afastaram da identidade com os Yaka. O nome Jaga foi muito utilizado pelas autoridades portuguesas, que chamavam a tudo de Jagas, como quer Miller. Os descendentes da Lunda, em determinado momento histórico, aceitaram o título Jaga como uma patente dada pelos portugueses.

Discordamos da intenção de Miller de retirar a noção de Jaga da história de Angola no século XVII. Não se pode tratar a questão como um erro das fontes, como o autor afirmou várias vezes. Se um narrador em Angola no século XVII identificou estes atores históricos como Jagas, não podemos negar a associação que estes tinham com os bandos que invadiram o Congo em 1568. Seus hábitos, costumes e ritos eram próximos.

A identidade que as fontes encontraram entre os invasores do Congo e os descendentes da Lunda, para nós historiadores de hoje, é importante. O próprio Cassanje, tão poderoso, foi exaustivamente chamado de Jaga pelas fontes. De alguma forma ele incorporou o título Jaga em seu nome. Devemos refletir sobre a alteração que o nome Jaga sofreu no contexto do século XVII, em que autoridades africanas incorporaram a designação dada pelos portugueses, que já não se referiam a uma única etnia, supostamente a Yaka, do norte do Congo.

Mais esclarecedora é a opção feita por Jan Vansina em seu último livro, publicado em 2004, que após toda esta discussão historiográfica optou por chamar este grupo de Jaga, e não de Mbangala. Vansina defende que este povo, ainda que heterogêneo, tinha uma forma de governo própria que foi eficaz e conseguiu se impor por mais de um século. Seguindo seus ensinamentos, optamos por manter a designação Jaga, tantas vezes utilizada pelas fontes, para desenvolver a presente dissertação.

Depois deste longo percurso historiográfico, Vansina sintetizou a migração dos Jagas através da elaboração de um mapa, que evidencia o "corredor" que percorreram 
de sul a norte de Angola, até chegarem à bacia do Kwanza no final da migração em massa.

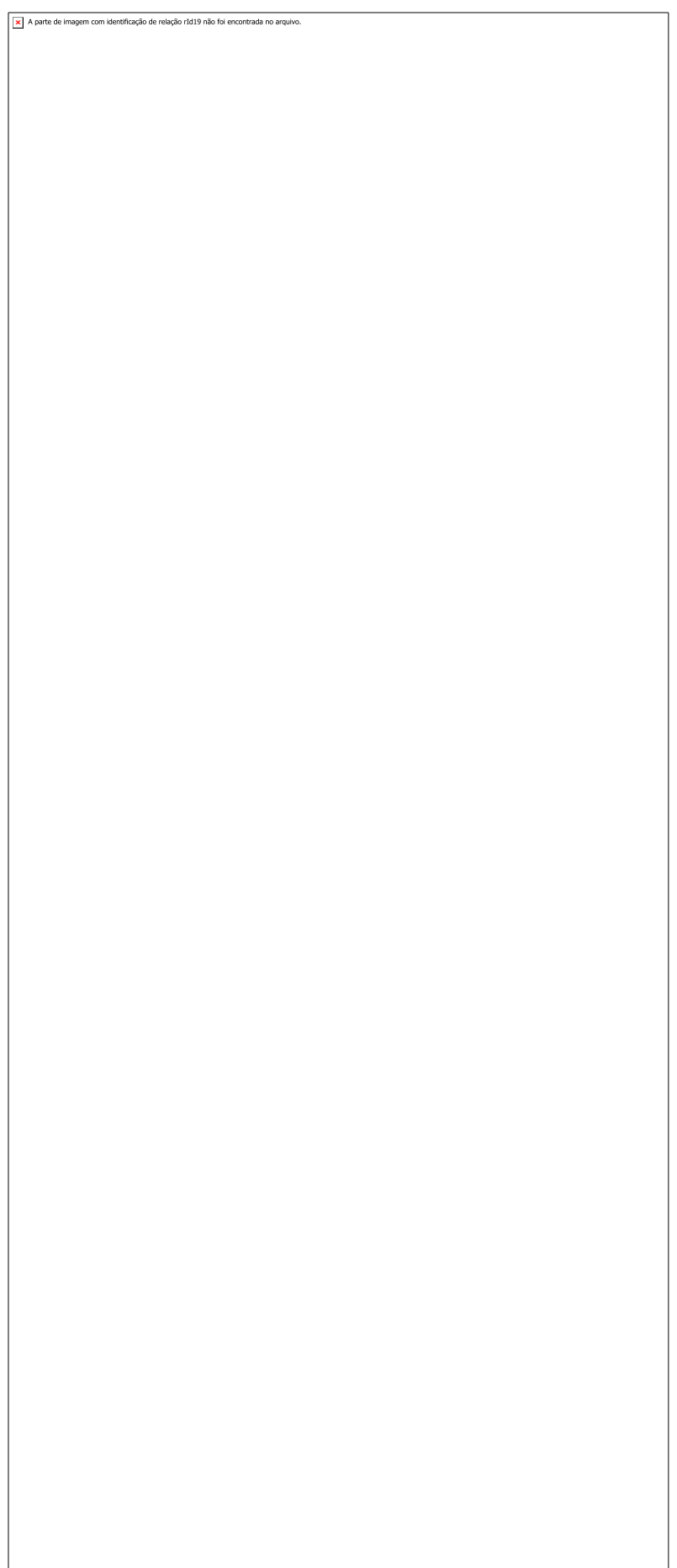

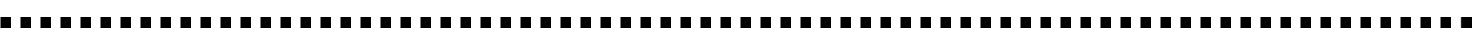

Em Vansina. How societies are Born. P. 198 


\section{Capítulo 02. Angola portuguesa: Conquista e resistência}

\subsection{Formação da colônia portuguesa de Angola}

Em meio ao processo de centralização e expansão do reino do Ngola, os portugueses começaram a articular a colônia portuguesa de Angola, clara adaptação do nome do principal governante daquele reino. A "conquista" de Angola deve ser entendida no contexto da expansão do Império marítimo português, que pretendia obter o monopólio da navegação e do comércio em todas as novas áreas conquistadas e impor a religião cristã aos povos considerados pagãos, autorizado por diversas bulas papais. ${ }^{101}$

Os portugueses haviam chegado à África Central no final do século XV e obtiveram grandes sucessos com o batismo do maniCongo em 1491. Mas ao longo do século XVI, a relação com os portugueses não permaneceu pacífica e amistosa como começou.

A presença de comerciantes brancos no reino do Ngola é documentada desde $1504,{ }^{102}$ quando estes, fugindo da instabilidade política do reino do Congo, buscaram as terras mais ao sul. No contexto desses novos contatos, circulou um boato na corte do Congo dizendo que o Ngola solicitava missionários para seu reino, pois desejava se converter ao cristianismo.

Em resposta à solicitação, D. Manuel, rei de Portugal enviou a primeira expedição às terras do Ngola em 1520, com objetivo de batizar o soberano e averiguar as riquezas daquela terra. A prata, explicitamente, despertava os interesses do rei de Portugal. ${ }^{103}$

A missão, entretanto, não foi bem sucedida. Um dos emissários, o escrivão Baltasar de Castro, foi aprisionado pelo Ngola, permanecendo como refém por seis anos. Em 1526, ele escreveu de Mbanza Congo ao rei D. João III, contando como havia sido solto pela intervenção do maniCongo D. Afonso. ${ }^{104}$

\footnotetext{
${ }^{101}$ Boxer, Charles. O Império Marítimo português. 1415-1825. São Paulo: Companhia das Letras, 2002. E Curto, Diogo Ramada. Cultura imperial e projetos coloniais: séculos XV a XVIII. Campinas: Editora UNICAMP, 2009.

${ }^{102}$ A primeira notícia sobre as terras do Ngola está em Brásio, Antonio. Vol. II. Doc. 46.

103“'Regimento dado por el-rei D. Manuel a Manuel Pacheco e Baltasar de Castro, que foram descobrir o reino de Angola." Em Felner. Angola, século XVI - documentos. p.21.

${ }^{104}$ Brásio. Vol. I. p. 485
} 
Mas o desejo português de comercializar nas terras do Ngola permaneceu. A intensificação do comércio com o Ngola desagradava o Congo, que via sua soberania ameaçada. Os planos dos comerciantes de São Tomé eram aumentar o tráfico clandestino com Ndongo e sair da órbita de controle de São Salvador, auxiliando o Ngola a conquistar a independência em relação ao Congo.

A batalha do Ndande, em 1556, marcou a autonomia do Ngola, que conseguiu derrotar o Congo. Para consolidar seu poder autônomo, orientado por comerciantes de São Tomé, o Ngola mandou uma embaixada a Lisboa pedindo padres para converter seu reino. A embaixada ficou aguardando embarque em São Tomé por alguns anos. O estudioso Carlos Alberto Garcia suspeita que tal demora ocorreu pelo receio do rei português em desagradar seu então parceiro, o mani Congo. ${ }^{105}$ Quando finalmente a missão chegou a Portugal foi recebida pela regente D. Catarina, que hospedou os embaixadores na casa de padres da Companhia de Jesus, a quem encomendou a preparação da nova missão às terras do Ngola. A articulação entre Coroa portuguesa e Companhia de Jesus para a conquista de Angola é evidenciada em vários documentos. ${ }^{106}$

Entretanto, o Ngola que havia solicitado o batismo morrera e fez-se necessário saber se o novo Ngola estaria disposto a se converter como seu antecessor. Para isto, a regente D. Catarina consultou o bispo e o capitão de São Tomé. ${ }^{107}$ Após alguns anos, o sucessor mandou resposta afirmativa, assim a Coroa portuguesa prosseguiu com a articulação da missão com a Companhia de Jesus, que zarpou do Tejo em 1560.

Paulo Dias de Novais, neto de Bartolmeu Dias, foi nomeado capitão da caravela, responsável por acompanhar os jesuítas. Ao chegar ao território do Ndongo, Paulo Dias foi alarmado por portugueses residentes ali que desaconselharam o encontro direto com o Ngola, que seria Dambe a Ngola (Ndambi a Ngola ou Ngola Kiluanji Kia Ndambi),

\footnotetext{
${ }^{105}$ Garcia. Carlos Alberto. Paulo Dias de Novais e a sua época. Agência Geral do Ultramar, 1964. p. 150. ${ }^{106}$ Carta do padre Inácio de Azevedo para o padre Diogo Lainez. 19 de Maio de 1558. Brásio. Vol.II. p. 411. Carta do padre Francisco de Bórgia para o geral da Companhia, de 20 de Maio de 1558. Brásio. Vol.II p. 415

${ }^{107}$ Em Felner, Alfredo de Albuquerque. Angola. Doc.19. p.406
} 
filho de Ngola Inene, que solicitara os missionários anos antes. ${ }^{108}$ Depois de muito hesitar, Paulo Dias resolveu subir o rio Kwanza e conhecer pessoalmente o Ngola. O soberano Mbundo chegou a dar vinte jovens ao padre Francisco de Gouveia, para serem educados, o que despertou a esperança dos missionários. Todavia, as expectativas se frustraram rapidamente: o Ngola não aceitava um Deus que condenava a poligamia e passou a chamar os europeus de feiticeiros, declarando "que lhe iam espiar a terra com mentiras e que os havia de degredar para outra terra." 109 Por fim, tomou-lhes tudo que levavam, proibindo-os de regressar ao litoral.

Os jesuítas atribuíram a hostilidade do Ngola a intrigas provenientes do maniCongo, a quem desagradava as relações diretas entre Portugal e Ndongo. Frequentemente o maniCongo aparece, nas correspondências missionárias, alertando o Ngola do perigo das relações com os portugueses. ${ }^{110}$ Mas estas acusações de intrigas vindas do Congo devem ser vistas com ressalvas, uma vez que os jesuítas haviam sido expulsos daquele reino por D. Diogo em 1553 e não eram mais benvindos nas terras ao norte. Delgado indica que os jesuítas tinham a intenção de minar a influência do Congo na região, deslocando o eixo comercial para Angola. ${ }^{111}$ Os portugueses residentes no Ndongo também influíram para o mau recebimento dos enviados da Coroa, já que o comércio existente com o Ngola poderia ser prejudicado pela intervenção do governo lusitano.

Uma carta do Padre Francisco de Gouveia, conta que os cativos foram mal alimentados, espancados, abandonados. ${ }^{112}$ Foram classificados de escravos do Ngola, cosiam-lhe as roupas e eram obrigados a fazer serviços degradantes. E relatou que o Ngola se interessava mais pelas sedas e bebidas ofertadas do que pela palavra de Deus. Desviava-se quando a questão era sobre a conversão ao cristianismo e fingia não entender o que eles perguntavam, sempre zombava das coisas da religião, dando pouca atenção dava às coisas de Deus.

\footnotetext{
${ }^{108}$ História da residência dos padres da Companhia de Jesus em Angola e cousas tocantes ao reino e conquista. 1/5/1594. Em Brásio. Vol.VI.p.552.

${ }^{109}$ Carta do irmão Antonio Mendes para o padre Leão Henriques, de 29 de Outubro de 1562. Em Gastão Sousa Dias. Relações de Angola. p.33.

${ }^{110}$ Carta do irmão Antonio Mendes, de 9 de Maio de 1563. Brásio. Vol.II. p.495- 512.

${ }^{111}$ Delgado, Ralph. História de Angola. Vol.I. p. 227

${ }^{112}$ Carta do Padre Francisco de Gouveia para o padre Diogo Mirão, de 1 de novembro de 1564. Em Felner, Luiz. Angola no século XVI-documentos. p.36
} 
Paulo Dias permaneceu como cativo por cinco anos e, segundo o Catálogo dos Governadores do Reino de Angola foi libertado para que fosse a Portugal buscar socorro militar para conter a revolta de um vassalo rebelado chamado Quiluange Quiacongo. ${ }^{113} \mathrm{O}$ embaixador retornou a Lisboa levando presentes ao rei de Portugal:

"a visitar sua alteza e levando como presente quarenta argolas de cobre e trinta e cinco dentes de alifante e quarenta paos que caá chamaõ de quicongo que é muyto estimado nestas paragens e assim manda mais certos escravos mãdando pedir por isso milhares de cousas." $" 114$

Desconfiamos que não foi este o motivo real da libertação de Paulo Dias, pois sendo o Ngola um rei tão poderoso, que já conseguira combater o potente exército do Congo, não teria dificuldades em vencer um soba menor que se rebelara. No entanto, o embaixador chegou a Portugal com promessas de retornar ao reino do Ngola.

Chegando ao Tejo, Paulo Dias foi recebido com singular entusiasmo, assim como a "causa angolana". A Companhia de Jesus, animada, prontificou-se em auxiliálo, com a justificativa de libertar o padre Francisco de Gouveia. Diante da impossibilidade de converter as massas bárbaras sem o uso da força, aconselhava-se a mudança da política de cooperação pela política de conquista. Assim, em vez de nova missão religiosa para Angola, composta por embaixador e presentes, defendeu-se o envio da primeira expedição militar, que impusesse a conversão pelas armas.

A necessidade de intervenção militar para garantir a conversão foi abertamente defendida pelo jesuíta Maurício Serpe:

"Trata-se cá de fazer nova missão a Angola, onde está aquele nosso padre Francisco de
Gouveia, retido há perto de nove anos com muitos trabalhos, sem se confessar e sem
dizer missa, e com comer muito mal e vestir muito pior, sem fazer nenhum fruto e sem
poder sair daquela terra; nos quais trabalhos até agora deu bom exemplo de si e muitas
mostras de virtude. E porque se tem de cá mui bem entendido por isto e por outras
experiências, que a cristandade em gente bárbara não se pode bem fundar nem se
pode conservar sem sujeição - o que não acontece com gente polida, como são os
chinas e japões - determinaram S.S.A.A. agora ultimamente de mandar sujeitar esta
terra e fundar nela nova cristandade, especialmente por informação do embaixador, que
foi com os padres (...) O padre tem escrito por algumas vezes do estado e disposição
daquela gente, e o principal é dizer que, se não for sujeita, que não tem remédio, mas

\footnotetext{
${ }^{113}$ Catálogo dos Governadores do Reino de Angola. "Arquivos de Angola". Vol.III. p. 460.

${ }^{114}$ Felner, Luiz. Angola no século XVI- documentos. p.114. Nota 1.
} 
se houvesse nela alguma sujeição, que todos se fariam cristãos e muito bons cristãos." ${ }^{115}$ (grifo nosso)

Juntamente com a ida de uma armada para o reino do Ngola, o rei de Portugal desejava que fosse uma nova missão jesuítica, o que também fora antes solicitada por Paulo Dias. Depois de três anos de preparativos, a missão saiu de Portugal em 23 de Outubro de 1574, com armada composta tripulantes, eclesiásticos, servidores e soldados, num total de 700 homens. ${ }^{116}$ Os padres Garcia Simões, como superior, e Baltasar Afonso, e os irmãos Gomes e Constantino Rodrigues formavam a missão religiosa.

A carta de doação dada a Paulo Dias, nos moldes das donatarias brasileiras, prescrevia que a conquista do então chamado reino de Angola deveria ser feita sem ajuda financeira ou de qualquer outra coisa por parte da Coroa. ${ }^{117} \mathrm{O}$ donatário se obrigava a cultivar e povoar as ditas terras, sob pena de perdê-las em quinze anos, obrigava-se também a pôr 400 homens de guerra no território e construir três "castelos de pedra e cal, entre os rios Zenza e Cuanza". A doação mandava que fossem também três clérigos "para confessarem e sacramentarem toda a gente armada" e que se construísse uma igreja sob a invocação de São Sebastião.

Quando Paulo Dias chegou à baía de Luanda, em fevereiro de $1575^{118}$, e encontravam-se ali sete barcos de traficantes de São Tomé e 40 portugueses residentes, fugidos do Congo pela invasão dos Jagas e pelas dissidências políticas nortenhas, todos muito ricos. Com a chegada da frota de Paulo Dias, os principais se apressaram em visitar o governador, a cumprimentá-lo e a conhecer os seus desígnios, dando boas notícias do padre Francisco de Gouveia, ainda preso.

A primeira ação política do novo governador foi convocar todos os portugueses residentes no sertão angolano para colher notícias da terra e do rei e explicar suas intenções. Apesar de alguns temerem as intervenções governamentais, a reunião se concretizou, tendo participado, além dos brancos, alguns principais da terra.

\footnotetext{
${ }^{115}$ História da Companhia de Jesus (H.C.J). Tomo II, vol.II. p. 506. citado em Delgado. op.cit. p. 272

${ }^{116}$ Uma história inédita de Angola. Do padre Francisco Rodrigues. p. 16. Na petição do governador, de 1588, fala-se em "uma armada de nove velas de alto bordo". Em Brásio. Vol.IV. p.481.

${ }^{117}$ Carta de doação a Paulo Dias de Novais. 19 de Setembro de 1571. Brásio. Vol. III. P. 36.

${ }^{118} \mathrm{Em}$ Uma história inédita de Angola, fala que chegaram a Luanda no dia 11 de fevereiro. Na carta do Padre Garcia de Simões, de 20 de Outubro de 1575 (Brásio. Vol.IV. p. 338.), diz que chegaram a Luanda em 20 de Fevereiro.
} 
Pouco antes do desembarque de Paulo Dias de Novais, Ngola Ndambi morrera, causando uma crise constitucional no Ndongo. A tradição recolhida por Gaeta, 80 anos depois, registrou Ngola Ndambi como um rei que usou os portugueses para expandir o reino nas regiões dos rios Dande, Zenza e Lukala, exatamente onde Paulo Dias de Novais o assistira ainda em 1564. ${ }^{119} \mathrm{O}$ sucessor teve que ser escolhido por uma eleição, em que os oficiais reais, incluindo o tendala, os makotas e o kilunda, conduziram o processo. De acordo com Garcia Simões, o poder foi temporalmente tomado por um "tirano que governou o reino" como um administrador, chamado Kilundo, mas ele foi morto pelo novo rei, que recebeu os emissários de Paulo Dias de Novais. ${ }^{120}$

O novo rei eleito, Nzinga Ngola Kilombo Kia Kasenda (1575-1592) se dizia bisneto do fundador do Ndongo, por uma linha diferente daquela que descendia Ngola Ndambi. Nzinga Ngola foi descrito como um rei muito temido e cruel, que travou sangrentas lutas contra os sobas e mandou decapitar dezenas de opositores, principalmente contra os sobas detentores do título Are, que reinvindicavam o trono do Ndongo, dizendo-se descendentes do primeiro Ngola. ${ }^{121}$

Ao saber da chegada do representante português, Nzinga Ngola mandou-lhe um mogunge (embaixador) a cumprimentá-lo, acompanhado de numeroso séquito, com mais de cem escravos e infinidade de gado, recebidos em homenagens pelo caminho. Depois das solenidades, o embaixador entregou a carta de que era portador ao Ngola. O governador trocou com ele muitos cumprimentos, dizendo que D. Sebastião o mandara àquela terra para servir o seu soberano, defender os portugueses e desfazer os conflitos existentes. "Folgou muito o rei com o presente e embaixada, especialmente por saber que o governador vinha com poder não para lhe fazer guerra, mas para o ajudar nas suas." 122

\footnotetext{
${ }^{119}$ Gioia da Napoli, Frei. La maravigliosa conversione alla Santa Fede di Cristi della Regina Sina e del suo regno di Matamba. Napóles, 1669.

${ }^{120}$ Garcia Simões para o provincial. 20 de Outubro de 1575. Brásio. Vol. III. P. 134.

${ }^{121}$ Cavazzi. Descrição história dos três reinos. Vol. II. P. 132. Garcia Simões para o provincial. 20 de Outubro de 1575. Brásio. Vol. III. P. 134. E Diogo da Costa para o provincial. 31 de maio de 1586. Brásio. Vol. III. P. 339.

${ }^{122}$ História da residência dos padres da Companhia de Jesus em Angola e coisas tocantes ao Reino e conquista (1/5/1594). Em Brásio. Vol. VI. P.553
} 
O ato diplomático aconteceu na choupana dos missionários que testemunharam tudo. O governador aproveitou para perguntar sobre as riquezas da terra e do reino. Passados três dias, o embaixador regressou à mbanza (moradia) do Ngola com ricos presentes.

Em meados de 1576, Paulo Dias deu ordem de governo com vereadores e mais oficiais de justiça e ergueu um forte de taipa, no morro batizado de São Paulo, em terras de senhorio de Manicabunga. Até então, os Portugueses estavam estacionados na ilha de Luanda, pertencente ao domínio do Congo, que autorizara a presença portuguesa.

As relações com o Ngola eram as melhores possíveis. Havia trocas de presentes entre D. Sebastião e o soberano, vivia-se uma verdadeira política de cooperação. Os portugueses andavam seguros em Angola e as boas relações chegaram a tal apogeu que Nzinga Ngola pediu a Paulo Dias um capitão para a sua capital para garantir a justiça nos negócios entre brancos e crioulos de São Tomé. Foi atendido pelo governador que mandou Pero da Fonseca, seu parente, acompanhado de vinte homens.

Os jesuítas não concordavam com essa ocupação de "águas-mornas", buscavam demonstrar a necessidade de se mudar a orientação, de iniciarem a sujeição pela violência, pois a conversão "destes bárbaros não se alcançaria por amor”, como afirmava Francisco de Gouveia, capitão no Congo, e o capitão de São Tomé, Diogo Salema. Assim, criticavam a postura de Paulo Dias, "devagar com o negócio da guerra".

Paulo Dias justificava sua política pelas próprias instruções de seu regimento ${ }^{123}$, mas conhecendo ele o grande poderio bélico do Ndongo, preferia não provocar o régulo e concentrar seus esforços na exploração do subsolo e no comércio de escravos.

Os jesuítas defendiam o endurecimento das relações, pois a substituição do índio por "escravos da guiné" já se tornava necessária, conforme defendido pelos inacianos no Brasil. Além do mais, uma política branda, como a desenvolvida no Congo, já se mostrara ineficiente para a Companhia de Jesus.

A aproximação da coroa portuguesa com o Ndongo não agradava o Congo, que receava perder suas receitas. O maniCongo Álvaro I, em 1577, oferecera ajuda para

\footnotetext{
123،"Dilatou-se a conquista deste reino perto de seis anos, porque tinha por Regimento que procedesse por via de paz e amizades.” Carta de Paulo Dias para o rei, de 12 de Janeiro de 1582. Em Brásio. Vol. IV. p. 335.
} 
Paulo Dias contra o Ngola, mandando seu sobrinho Sebastião Manibamba, com arcabuzeiros e muita gente, mas, desconfiado, o governador recusou a oferta supondo haver interesse do Congo nas riquezas de Angola: "se o não impedira, estivera hoje de posse de quase toda Angola e suas minas". ${ }^{124}$

A aliança do Ngola com o governo português lhe garantia a submissão dos inimigos e dos sobas rebelados. O Ngola usava os exércitos oficiais e comerciantes dispersos pelos sertões para garantir a ordem. Os comerciantes, por sua vez, gozavam do direito dado pelo Ngola de guerrearem livremente para garantir seus interesses materiais. Mas as relações entre o recém-instalado governo e os portugueses que já comerciavam lá não eram sempre pacíficas. Estes, temerosos de verem seus lucros diminuídos pela intervenção estatal, recusavam-se a obedecer às ordens que lhes pareciam impróprias e continuavam as razias e saques pelo interior. Um episódio pos fim a estas boas relações iniciais:

Conta-se que em 1579, Francisco Barbuda d'Aguiar, um português com mais de 25 anos de residência na África Central foi preso pelo Capitão Pero da Fonseca por deslealdade. Barbuda já havia sido acusado de fazer intrigas contras os portugueses no Congo, e em Lopez-Pigaffetta aparece alertando D. Álvaro I a não confiar na missão de Gouveia Sottomaior. ${ }^{125}$ Chegou ao Ndongo em 1579 e aproveitou a oportunidade para denunciar o rei de Portugal, o governador Paulo Dias e Pero da Fonseca, "em português e na língua do país". ${ }^{126}$ Foi aprisionado por Pero da Fonseca, mas por pouco tempo. Ao ser libertado, foi diretamente ao Ngola dissendo que tinha um "grande segredo": os homens de Paulo Dias estavam no Ndongo e que pretendiam tomar pelas armas suas minas, e "tinha gente pronta e muita pólvora, e bala, e que outra mais gente vinha marchando a encorporar-se com ele." 127

De fato, as tropas portuguesas avançavam lentamente pelo Kwanza acima. O Ngola, por conselho de seus makotas, deliberou exterminar o problema e fingiu uma guerra contra uma vila qualquer e pediu auxílio dos portugueses, que prontamente se dispuseram. O Ngola mandou massacrá-los, subitamente, após a vitória contra o suposto

\footnotetext{
${ }^{124}$ Carta do padre Baltasar Afonso, de 9 de Outubro de 1577. Em Brásio. Vol. III. p. 157-158.

${ }^{125}$ Lopez- Pigaffetta. P. 61.

${ }^{126}$ Auto de Pero da Fonseca. 18 de Abril de 1579. Brásio. Vol. IV. P. 308-309.

${ }^{127}$ História da residência dos padres da Companhia de Jesus em Angola e coisas tocantes ao Reino e conquista (1/5/1594). Em Brásio. Vol. VI. P.558.
} 
adversário. Morreram 30 a 40 portugueses residentes na corte e alguns brancos espalhados pelas imediações, e foram chacinados também mais de mil escravos cristãos. Simultaneamente, o Ngola roubou as fazendas dos massacrados e dez a doze navios parados na baia de Luanda, avaliadas em 60 mil cruzados, mandando ordem terminante a Paulo Dias de Novais, estacionado no rochedo de São Pedro, nas margens do Kwanza, para sustar sua marcha.

Paulo Dias decidiu suspender o avanço e preparou-se para o ataque do Ngola. Pretendia invadir as minas de Cambambe pela força, com o apoio do Congo, solicitado e prometido. Muitos luso-africanos do Congo e nobres congoleses se juntaram ao exército português - soldados que aparecem nas fontes como Africanos Cristãos- com o objetivo de atacar o Ndongo. ${ }^{128}$

Em 23 de fevereiro de 1580, chegou de Portugal novo socorro sob o comando de Diogo Rodrigues dos Colos composto por 200 homens. Vieram em sua companhia os padres jesuítas Baltasar Barreira e Frutuoso Ribeiro. Este socorro fora enviado pelo pai do governador, António Dias de Novais, para o qual o cardeal D. Henrique, inclinado para a questão angolana de longa data, emprestara vinte e dois mil cruzados. ${ }^{129}$

Paulo Dias buscou explorar o faccionalismo no Ndongo e impopularidade de Nzinga Ngola, recrutando o apoio dos sobas descontentes com o caráter violento do governante. Em maio de 1580, iniciou-se a campanha contra o Ndongo, em que os portugueses contaram com mais de 60.000 congoleses, 120 luso-africanos mercenários e vários sobas que esperavam se libertar do controle do Ngola. ${ }^{130}$

Passando-se para uma nova fase da conquista, novas estratégias precisavam ser pensadas. A paz inicial com o rei de Angola dava lugar a uma política de submissão pela força em que os sobas eram peças essenciais.

\footnotetext{
128 Memórias de Diogo de Ferreira. 1588. Brásio. Vol. IV. P. 491. E Cordeiro, Luciano. Questões histórico-coloniais. p. 188

${ }^{129}$ Uma História Inédita de Angola. p. 24.Na petição de 1588, Paulo Dias parece se referir a este socorro quando lamenta: "Antes (tem) recebidos muitos agravos, deste Reino, que chegaram a tanto que tendo seu pai dois galeões com gente, armas e munições neste rio de Lisboa, para o socorrer, lhe foram embargados pela mesa da Fazenda e lhos não deixaram partir sem dar fiança de dez mil cruzados com notificação a seu pai que não armasse mais navios." Brásio. Vol. IV. p. 483.

${ }^{130}$ Amaral, Ilídio. Consulado de Paulo Dias de Novais: Angola no último quartel do século XVI e primeiro do século XVII. Lisboa: Instituto de Investigação Científica Tropical, 2000. Pp. 132-137.
} 


\subsection{Submissão dos sobas, baculamentos e instituição dos amos}

Os sobas foram fundamentais do jogo político criado na conquista de Angola. Os poderosos que aceitavam cooperar com os anseios coloniais portugueses passavam por um ritual de vassalagem, análogo aos rituais medievais, muito usado por Portugal em suas conquistas ultramarinas. Os elementos essenciais do contrato de vassalagem eram, por parte do vencido, a declaração de consentimento, apoio militar, pagamento de tributos, fidelidade e obediência a Portugal e por parte do vencedor, a promessa de proteção e investidura.

O ritual de vassalagem foi comumente chamado na documentação de "por pezo de Muene Puto" ${ }^{131}$, em que Muene Puto designava o Rei de Portugal e "Pheezo" ou "pezo" era a designação usada no Yombe, região do Zaire-Kassai, e também na região do Ndongo, para o barro branco empregado em rituais. ${ }^{132}$ Neste ritual, colocava-se farinha ou caulino nos ombros do soba, que era depois espalhada pelo peito e braços, simbolizando a fidelidade. As semelhanças com o sistema tradicional, no plano simbólico, serviam para criar correspondências políticas já conhecidas e assim conferir legitimidade ao ritual.

O vassalo continuava a ser livre, porém passava a dever lealdade e obediência à Coroa portuguesa. O vassalo era ainda obrigado a cooperar com os projetos colonizadores: abrigar e alimentar soldados, mercadores e traficantes em suas terras; aliar-se aos aliados e ser inimigo dos inimigos portugueses; dar passagem às tropas e pumbeiros; manter as feiras comerciais abertas em seu território.

O pagamento de tributos já era realizado no sistema tradicional, em que os sobas davam ao Ngola parte de sua produção em troca de segurança e chamava-se baculamento, nome que foi adotado pelas autoridades portuguesas como sinônimo de cobrança de impostos dos sobas vassalos. Mas tradicionalmente, os sobas disponibilizavam apenas os servos excedentes para o Ngola, segundo taxas previamente fixadas. O abuso da cobrança por parte dos portugueses levou à ruptura do sistema social tradicional, causando inúmeras guerras pelo interior, cujo objetivo era capturar escravos para saldar os tributos exigidos.

\footnotetext{
${ }^{131}$ Cadornega. História Geral das Guerras Angolanas. Vol. I. Passim.

${ }^{132}$ Doutreloux. L'ombre des fétiches: societé et culture Yombe. Louvain e Paris, 1967. Apud. Heintze. B.2007. p. 258.
} 
O período da primeira grande ofensiva portuguesa, de 1580 a 1607, foi determinado pelo avassalamento dos sobas à força e deu resultados positivos, embora efêmeros, principalmente nas províncias da Ilamba e da Quissama.

O primeiro soba a prestar obediência ao governador e tornar-se vassalo do rei de Portugal foi Muxima Quitangonge (ou Quitambonge, Muxima ua ngombe). Este foi ao encontro do governador trazendo muitos mantimentos, capados e bois, "pedindo-lhes dessem ajuda contra um seu inimigo, que ele em pessoa como todos os seus vassalos ajudaria ao Governador contra o mesmo rei de Angola e assim o fez". ${ }^{133}$

Apesar de esta primeira submissão ter sido voluntária, a maioria dos sobas foi submetida à força. Suas opções ficavam entre: resistência, execução, deportação para o Brasil como escravo ou o avassalamento. Alguns optaram por oferecer a vassalagem quando pensavam que a guerra para submetê-los estava próxima ou quando o Ngola representava um mal maior. Alguns sobas souberam aproveitar a oportunidade para ganhar um aliado de peso e se avassalaram quando precisaram de apoio militar urgente contra um vizinho.

$\mathrm{Na}$ narrativa de Cadornega nota-se que as alianças eram facilmente dissolvidas. Os sobas aliados aos portugueses frequentemente se rebelavam ou se aliavam a seus inimigos. A Coroa precisou investir grande soma em guerras para conter e reprimir as rebeliões dos vassalos, num jogo de alianças sempre flutuantes.

A situação financeira da conquista se agravou a partir de 1580. Faltava alimento para as tropas, remédios, soldos. Os jesuítas também sofriam as dificuldades e prestavam apoio cada vez maior a Paulo Dias. Como a carta de doação o permitia através do sistema de sesmarias, o governador indenizou os missionários com doação de terras, em grandes escalas, a partir de 1581. Conquistadores e portugueses de mérito também se beneficiaram por este meio, como Garcia Mendes Castelo Branco e o mineiro Rodrigues de Godói. Entretanto, a Sociedade de Jesus foi, sem dúvida, a entidade mais favorecida com a doação de terras em Angola. As terras doadas correspondiam muitas vezes a sobados inteiros e incluíam todos os seus habitantes, bens, águas. Os jesuítas ganharam o direito de nomear e destituir, segundo seus interesses, os alcaides-mores de seus territórios. Normalmente, as propriedades dos

${ }^{133}$ Carta do Padre Baltazar Afonso para Miguel de Sousa, de Loanda, 4/7/1581. Brásio. Vol.III. p. 200 
religiosos consistiam em grandes extensões de terras e estavam isentas de impostos. Nas demais, dever-se-ia pagar o dízimo à Igreja e $2 \%$ por ano dos lucros dos engenhos e moinhos, mais $40 \%$ em caso de vendas. ${ }^{134}$

No entanto, em Angola, ninguém estava realmente interessado no aproveitamento agrícola do solo. Os escravos eram a principal riqueza e a doação de terras era uma forma de adquiri-los sem grandes custos. $\mathrm{O}$ novo proprietário tinha $\mathrm{o}$ direito, expresso ou implícito, de dispor livremente dos africanos residentes em seu território. Assim, o contrato de colonização se tornou um instrumento do comércio de escravos, cujo único objetivo era o rápido enriquecimento pessoal.

A doação de terras se dava com o ritual de vassalagem do soba. O novo proprietário era chamado de amo, adaptando-se uma antiga instituição já existente nas tradições angolanas. Quando Paulo Dias e o padre Francisco de Gouvéia foram feitos reféns do Ngola, atribuiu-lhes um amo, chamado Gongacinza, para que servisse de intermediário com o rei. $\mathrm{O}$ amo na tradição Mbundo, atuava como "traço-de-união entre a comunidade e o forasteiro, facilitava a vida deste, ajudava o recém-chegado a adaptarse ao novo ambiente e evitava que agisse de forma incorreta ou ferisse os costumes locais." 135 Em contrapartida, o amo deveria ser o intermediário preferido nas trocas comerciais. A História da Companhia de Jesus buscou na tradição já existente a legitimação da instituição:

"em se sujeitando um soba, a primeira coisa que fazia, pedia logo amo, a quem tivesse na corte do governador, por conservador e protector, para em tudo the obedecer e recorrer a ele. Porque assim o fazem também com o rei de Angola. "136

Inicialmente, os Mbundo aceitaram de bom grado a instituição dos amos, por já ser do seu costume, mas o constante abuso dos portugueses que, além dos escravos, exigiam serviços, alimentos, hospedagem, fez com que muitos se rebelassem. Tradicionalmente, o amo era um procurador, um intercessor nas disputas com os europeus, porém a instituição fora desvirtuada para favorecer o rápido enriquecimento dos donatários. Além de escravos, os sobas também davam a seus amos gêneros

\footnotetext{
${ }^{134}$ Brásio. Vol. IV. p. 436-438.

${ }^{135}$ Costa e Silva. A manilha e o libambo. Rio de Janeiro: Nova Fronteira, 2002. p. 417.

${ }^{136}$ Missão dos Jesuítas em Angola (1602-1603). Em Brásio. Vol. VII. P. 51
} 
alimentícios, mandavam construir casas, semear os campos, fazer serviços de carregadores:

"O capitão ou soldado que tem soba pode tirar dele muito proveito, a saber, massa, azeite, vinho da terra para os de sua casa, galinhas, capados, etc. Também podem mandar semear e recolher por seus escravos em terra de seu soba legumes e outros mantimentos". 137

Muitas vezes, resultava em excesso por parte dos portugueses e o soba se rebelava, ao que era imediatamente respondido com guerra considerada justa. $\mathrm{O}$ soba temia perder seu prestígio e poder diante de seus dependentes, colocado à prova pela insistente cobrança de escravos, o que o obrigava muitas vezes, a fazer razias contra um povoado vizinho, ou sequestrar rapazes em outras aldeias, ou a tornar-se mais rigoroso na aplicação de leis que previam a escravização, ou até inventar novos crimes. Assim, a comunidade se enfraquecia, tornando-se cada vez mais insegura com a multiplicação de intrigas e delações.

O proveito econômico, em forma de tributos, fora doado por Paulo Dias, em nome da Coroa, aos amos, em consequência da doação de terras. Os missionários e os amos seculares recebiam as doações de terras, ou as receitas dela provenientes, expressamente para seu sustento pessoal ou para manutenção de igrejas e colégios. ${ }^{138} \mathrm{~A}$ Sociedade de Jesus também recebera de Paulo Dias o direito a uma parte de qualquer mina de prata que fosse descoberta em Angola (mas que nunca foi de fato encontrada) e o terço do dízimo da igreja, que depois fora retirado pelo rei D. Sebastião. O rendimento das terras, em gêneros e serviços, era de tal importância para os jesuítas que levou a conflitos, tanto em Angola, como no seio da ordem em Portugal.

A Companhia de Jesus proibira a utilização de escravos nas casas da Sociedade, mas vendo que seu uso era tão comum e necessário em Angola, foi obrigada a rediscutir a questão em seus conselhos superiores.

A provisão de sete de outubro de 1583 concedia aos jesuítas em Angola o subsídio anual de $42 \$ 500$ réis por pessoa, valor muito pequeno em relação a outros vencimentos e às despesas que se tinha com mantimentos, e este subsídio ainda não foi pago durante os anos de 1586-1596, apesar do Alvará de 22 de novembro de 1592

\footnotetext{
${ }^{137}$ História da residência dos padres da Companhia de Jesus em Angola e coisas tocantes ao Reino e conquista (1/5/1594). Em Brásio. Vol. VI. P.558.

${ }^{138}$ Brásio. Vol. III p. 357. e Felner.Angola no século XVI.p. 463
} 
determinar o pagamento. Os padres receberam de seus sobas, em 1590, 300 escravos, fora todos os outros tributos, escravos domésticos e serviços. Podiam exportar estes escravos ao Brasil, isentos de direitos, onde seriam vendidos por $8 \$ 000$ ou $10 \$ 000$ réis cada um, o que representava uma cifra bem maior do que seus salários e bem maior do que suas despesas. Uma parte deste lucro era empregada no "apoio à conquista", que incluía a aquisição de pólvora e armas.

Argumentos de ordem moral também foram frequentemente apresentados pelos jesuítas, que se colocavam como protetores e defensores dos sobas, alegavam que tinham como missão consolá-los, acalmá-los e defender seus interesses perante o governador.

A convicção dos jesuítas de que eram os protetores, por excelência, dos índios e das populações nativas submetidas pela colonização, teria influenciado a compreensão dos missionários em Angola. O Provincial Sebastião de Morais expõe o papel dos jesuítas nos conflitos entre os "seus" sobas e o governo:

"Era grande a inquietação que lhes causavam os sobas nas suas queixas e pretensões e muitos desgostos que por eles os amarguravam. Recorriam os sobas aos padres, nas diferenças que tinham com os Portugueses e com o governador, e nasciam necessariamente desconfianças, melindres e irritações entre estes e os padres, que defendiam aos sobas, seus protegidos." 139

Em geral, os sobas preferiam ter os jesuítas como amos do que os conquistadores. Em 1587, vários sobas se rebelaram contra o poder dos militares e diante desta revolta, 47 conquistadores escreveram a Paulo Dias, pedindo que se notificasse "o padre Baltasar Barreira, superior, e em seu nome, ao padre Diogo da Costa, residentes neste Massangano, não largassem de si os ditos sobas, tivessem em seu poder até a terra tomar outro assento."

É importante salientar que a instituição dos amos se diferencia do sistema de encomiendas praticado na América Espanhola. Em Angola, a instituição se iniciou como uma concessão de terras de caráter hereditário, em que o beneficiamento

\footnotetext{
${ }^{139}$ História da Companhia de Jesus, Tomo II,vo.II p. 532.

${ }^{140}$ História da residência dos padres da Companhia de Jesus em Angola e coisas tocantes ao Reino e conquista (1/5/1594). Em Brásio. Vol. VI. P.559.
} 
econômico compreendia o recebimento de escravos. A instituição dos amos também nunca foi regulamentada por leis no que toca ao trabalho forçado, aos tributos e à cristianização, como se percebe nas encomiendas. Em Angola, tudo ficava a cargo dos amos que, oficialmente, não tinham a obrigação de proteger nem de instruir.

Da mesma forma, esta instituição não tinha a ver com os aldeamentos praticados no Brasil. Catequizar a população local não foi de modo algum a motivação principal dos jesuítas em Angola. A doação de terras era mais entendida como forma de conseguir tributos e apoio para as expedições militares do que ter alguma influência teológica junto à população local, vista apenas como escravos em potencial. $\mathrm{O}$ batismo, quando obrigatório, era apenas dado aos sobas e aos principais da terra. Outra diferença é que, a maioria das aldeias do Brasil eram lugares para onde os índios eram transferidos, obrigados a abandonar o modo de vida nômade. Formava-se uma nova comunidade, dirigida pelos missionários e sem correspondências com a vida social já existente. Em Angola, as terras doadas correspondiam a áreas já debaixo da jurisdição de um determinado chefe, que não perdia a influência e o poder sobre seus súditos, assim as terras e gentes que lá habitavam continuavam sob controle do soba.

Os jesuítas foram os amos preferenciais de Paulo Dias de Novais porque foram eles os maiores apoiadores, no plano ideológico e material, de seus projetos colonizadores. A Companhia de Jesus constantemente pedia ao rei de Portugal recursos para garantir a colonização de Angola e ainda sustentava o "mito da prata" na corte. A suposta existência de metais preciosos em Angola fazia com que a Coroa mantivesse os interesses coloniais ali e, apesar da carta de doação determinar que a conquista deveria se dar sem o auxílio real, a defesa veemente dos religiosos fomentava a ida de recursos para a empresa colonial.

Filipe II da Espanha e I de Portugal assumiu a Coroa portuguesa em 1580. Paulo Dias lhe prestou homenagem em 1582 e solicitou auxílio para continuar a conquista, demasiadamente dispendiosa. Os jesuítas, já conhecedores dos projetos do novo rei, foram os maiores cultivadores do dito "mito da prata", pois sabiam que o simples desejo de evangelização não motivaria a Coroa a financiar a colonização em Angola. Era necessário outro motivo que seduzisse o rei, e a prata se adequava muito bem aos anseios metalistas da Península Ibérica deste período. 
É visível o esforço do jesuíta Baltasar Afonso para garantir a ajuda da Coroa para a efetiva colonização de Angola. Ele e o padre Baltasar Barreira foram os principais defensores de Paulo Dias de Novais junto à corte e o auxiliaram efetivamente na conquista do território. É fácil perceber, por suas cartas, como a imagem do governador é exaltada, assim como seus feitos militares:

"São tantas as vitórias que os nossos têm alcançado destes nossos inimigos que não se pode crer por carta, principalmente, tendo até aqui por impossível poder-se conquistar Angola sem grande poder dos portugueses e quer Deus que o governador com cem tem tomado a metade do reino de Angola, e sujeitando muitos e grandes fidalgos, que com ele vão conquistando a terra toda. Em obra de três meses venceu três guerras do próprio rei de Angola, matando e cativando infinidade deles. Somente falta ajudá-lo el-rei desse reino com pólvora e munições, e alguma gente para que se vão refazendo em lugar dos que morrem." ${ }^{141}$ (grifo nosso)

Apesar da carta de doação de D. Sebastião estabelecer que os custos da conquista ficassem a encargo do donatário, os jesuítas tentaram convencer a Coroa a ajudar esta obra, que poderia lhe render muitos frutos. O que se percebe é a tentativa de Paulo Dias, com o apoio dos missionários jesuítas, para substituir o sistema de capitania implantado por uma "colônia de exploração", transferindo-se assim os custos à Coroa.

Em seu testamento, Paulo Dias glorificou a ação da Companhia na conquista de Angola:

"Peço a Sua Majestade não consista que os Padres da Companhia de Jesus desamparem esta conquista pois foi cavada desde o princípio e adquirida com seus conselhos e ajudas espirituais. E aos mesmos padres pelo e requeiro da parte de Jesus Cristo, por cujo amor cometeram esta empresa, que a levem por diante, e a cultivem com sua vida e exemplo e doutrina, para que nela se multipliquem os filhos de Deus, e a fé católica que começaram a plantar se estenda por esta grande gentilidade."

Entre os anos de 1560 a 1593, vinte e seis jesuítas foram a Angola, onze dos quais faleceram e três regressaram à Metrópole. ${ }^{143}$ Destaca-se a atuação do padre Baltasar Afonso, o pioneiro das missões pelo sertão que realizou muitos batismos pelas margens do rio Kwanza, e do padre Baltasar Barreira, que Delgado chamou de "o grande coadjuvador de Paulo Dias e dos seus sucessores, tanto no campo material, como no espiritual." ${ }^{144}$ Através das cartas deste missionário, percebe-se sua inserção no

\footnotetext{
${ }^{141}$ Carta do padre Baltasar Afonso. 31 de julho de 1582. Em Brásio. Vol. III. p. 219. (grifo nosso)

${ }^{142}$ Testamento de Paulo Dias de Novais. 24 de Outubro de 1582. Em Brásio. Vol. IV. P. 156.

${ }^{143}$ Uma História Inédita de Angola. Em Brásio. Vol. III. p.36.

${ }^{144}$ Delgado. História de Angola. Vol. I. P.363
} 
exército, sendo até indicado como comandante de esquadrões. Seus relatos são verdadeiros diários de guerra em que o aspecto religioso ficou relegado a segundo plano. $^{145}$

A morte de Paulo Dias de Novais, em nove de maio de 1589, desarticulou a conquista e paralisou o sistema de exploração do território. Luis Serrão sucedeu ao donatário e seu curto governo, ainda sustentado pela expectativa da prata, foi marcado por conflitos com os comerciantes de zimbos (conchas usadas como moeda no Congo) e pela necessidade de vencer o Ngola para assegurar a conquista territorial. Em sua substituição, o povo e capitães elegeram o capitão-mor André Ferreira Pereira. O padre Baltazar Barreira fora eleito pelas Câmaras de Luanda e Massangano, mas não chegou a tomar posse. ${ }^{146}$

O governo de Ferreira Pereira marcou o final da "Capitania e Governança de Angola”, já muito abalada em seu projeto original. Paulo Dias falecera sem deixar herdeiros, e a Coroa, interessada em saber a situação real da conquista, mandara a Luanda o licenciado Domingos de Abreu de Brito fazer um inquérito. Vindo do Brasil em 1590 e retirando-se de Angola em quatro de março de 1591, o nomeado analisou a economia do novo reino e traçou metas para prosseguir a conquista do território através da criação de um governo-geral. ${ }^{147}$ Assim, desfeita a carta de doação, iniciava-se uma nova época colonizadora, em que a Metrópole figuraria como exclusiva orientadora e financiadora da colonização angolana. ${ }^{148}$

Em 1592, chegou a Angola o primeiro governador-geral, D. Francisco de Almeida. Alinhado com os propósitos centralizadores de Felipe II, aceitou o cargo em

\footnotetext{
${ }^{145}$ Carta do padre Baltasar Barreira ao provincial, 20/11/ 1584 e Carta do padre Baltasar Barreira ao provincial do Brasil, no ano de 1585. Em Felner, Luís. Angola no século XVI- documentos. pp. 124- 132. Carta do padre Baltazar Barreira ao padre Sebastião de Morais, de 31/1/1582 Em: Brásio. Vol.III. doc.n'07.p.209

${ }^{146}$ Farinha ,Padre Lourenço. A expansão da fé na África e no Brasil.. p. 224.

${ }^{147}$ Brito, Domingos de Abreu e. Um inquérito à vida administrativa e económica de Angola e do Brasil em fins do século XVI (1591). Editado por Alfredo de Albuquerque Lima Felner. Coimbra: Imprensa da Universidade, 1933.

${ }^{148}$ Antes de nomear sucessor para Paulo Dias, o rei ouviu o procurador da Coroa, Dr. Jorge de Cabedo o licenciado Lourenço Correira e os desembargadores do Paço, acerca dos direitos reais sobre a capitania, sendo todos favoráveis ao rei dissolver a capitania hereditária visto que o donatário não cumprira suas obrigações. Brásio. Vol. III. p. 383, 391 e 401.
} 
regime de sociedade com o Coroa, cabendo-lhe a liquidação das despesas da conquista, embora auxiliado pelo rei. A conquista de Angola estava em estado de rebelião geral, vários sobas revoltados com a substituição da "política pacífica" inicial para uma "política de força" combatiam o poder português. A conquista estava ameaçada, assim como a vida de todos os conquistadores.

Os excessos cometidos pelos amos já eram denunciados na corte e via-se que a substituição da donataria era uma boa oportunidade para se abolir tais direitos. Francisco de Almeida foi o escolhido para assumir o governo de Angola com provisão real que tirava os sobas do poder dos conquistadores e dos padres da Companhia de Jesus, pois a instituição foi considerada nociva à autoridade da Coroa e aos interesses da Fazenda Real.

Em 1594, Pêro Rodrigues, visitador da residência dos padres da Companhia naquele reino, escreveu a História da residência dos padres da Companhia de Jesus em Angola. Na tentativa de dissuadir a Coroa de acabar com o privilégio dos amos jesuítas, a relação conta que os senhores de sobas eram obrigados, por costume, a gastar boa parte do tributo com o próprio soba:

"em vinhos, sedas, e panos finos, como é de vinte peças que lhe traz, há-de gastar valia de sete ou oito. Donde se entende o quão grande e excessivo gasto El-Rei nosso senhor tomaria sobre si se deitasse a mão dos sobas deste reino, os quais, com é dito, são em número, setecentos e trinta e seis, fora outros de que ainda se não sabe, pois conforme a este costume de obrigava a sustentar um riquíssima alfândega de todo o gênero de sedas e outras coisas de preço de Portugal e da Índia, para satisfazer a tanto número de sobas, quando lhe viessem pagar seus tributos." 149

Heintze denunciou a estratégia dos padres que, ao mostrarem os custos da doação, pretendiam dissuadir a Coroa de submeter os sobas diretamente ao seu poder, devendo permanecer nas mãos dos particulares. ${ }^{150}$ Provavelmente, esta contraprestação não era tão alta como diz o documento do jesuíta.

Iniciou-se então a uma série de protestos que contrapuseram jesuítas e governo. O padre Baltasar Barreira liderou a rebelião contra o governador e a nova orientação metropolitana. As demonstrações de forças chegaram ao extremo do governador proibir

\footnotetext{
${ }^{149}$ História da residência dos padres da Companhia de Jesus em Angola e coisas tocantes ao Reino e conquista. (1/5/1594). Em Brásio. Vol. VI. P.558.

${ }^{150}$ Heintze, B. Angola nos século XVI e XVII. p. 208
} 
os padres de alimentarem os soldados pobres. O padre Barreira, por sua vez, excomungou o governador por "autoridade do seu conservador". ${ }^{151}$

O governador D. Francisco de Almeida acabou sendo expulso de Angola e o povo e a Câmara de Luanda convidaram seu irmão, D. Jerônimo de Almeida, a assumir o governo da colônia, pois esteve ao lado dos revoltosos. O novo governador acatou a sugestão do padre Barreira de suspender a provisão real até nova deliberação do rei.

É inegável a importância dos padres da Companhia de Jesus nos primeiros anos da conquista portuguesa em Angola. Delgado afirmou que foram "fundamentais e decisivos". ${ }^{152}$ Atuaram politicamente, junto à Coroa, para obterem recursos para a conquista de Angola, a fim de convencer as autoridades de como ela era importante e poderia gerar grandes frutos. Para isso insistiram em sustentar o "mito da prata" e das riquezas do subsolo angolano, sobretudo no reinado de Filipe II de Espanha e I de Portugal, notoriamente interessado na busca por metais preciosos.

A importância dos escravos de Angola já era evidente na economia portuguesa do final do século XVI. Ao lado das guerras e das feiras, a "instituição dos amos" foi uma importante forma de adquiri-los, em forma de tributos. Além disso, a submissão dos sobas permitiu a penetração no interior e a conquista de novas terras, uma vez que os sobas eram obrigados a contribuírem nos exércitos, disponibilizando seus súditos para a "guerra preta" ou como carregadores.

Os jesuítas, os maiores contemplados nas doações de Paulo Dias de Novais, foram essenciais para garantir o controle e colaboração dos sobas. Os escravos que receberam engrossaram os números do tráfico negreiro para o Brasil, em comércio direto com as missões jesuíticas na América. O documento abaixo revela a inserção dos padres no comércio transatlântico, preocupados com o maior lucro:

"Que as peças se vendam em Angola pelos preços correntes, mas parece perda vender aqui por quatro o que no Brasil importa oito ou dez; que podem ir ao Brasil encomendados aos superiores dos colégios poucos e poucos, por modo que não seja notado, contanto que não se entenda receberem os padres disso opressão. Ao menos parece não escusamos mandar aos padres do Brasil as peças que eles para seu serviço

\footnotetext{
${ }^{151}$ História da Companhia de Jesus, Tomo II,vol.II p. 544

${ }^{152}$ Delgado. História de Angola.Vol. I. P.365.
} 
mandam pedir, e também outras para se pagar o que devemos aos colégios daquela província, de coisas que para nossa sustentação nos têm mandadas."

A menor parte dos negros recebidos foi utilizada como escravaria dos próprios jesuítas em suas fazendas. O visitador Pero Rodrigues orientava a possuir apenas os escravos necessários, já que a produção da terra era mínima:

"E quanto ao número dos nossos escravos, tenha o superior tento que não haja mais que os que boa mente se não podem escusar para o serviço da casa; porque a multidão deles é odiosa dos seculares e para nós trabalhosa de sustentar."154

Os objetivos evangelizadores são pouco encontrados na ampla documentação jesuítica. Além da queima de ídolos e alguns batismos em massa nas áreas ocupadas, a atuação missionária é mais evidente nas batalhas e nas articulações políticas. A catequização do povo angolano só existiu, de fato, nos números das cartas dos padres para mostrar a "boa obra" adquirida com tantas guerras. Os jesuítas organizaram mais expedições militares que paróquias e colégios, visto que o primeiro colégio só começou a funcionar em 1605. ${ }^{155} \mathrm{O}$ cristianismo não conseguiu superar a poligamia e as crenças ancestrais, os costumes tradicionais continuaram a vigorar, mesmo com a violenta repressão.

A poligamia, tão condenada pelos missionários, fazia parte da organização social e econômica em Angola. Ter muitas mulheres significava muitos arimos (plantações) e assim mais alimentos, mais riquezas. Dessa forma, poucos, ou de fato, nenhum soba realmente aceitou esta imposição do cristianismo, vista como inconcebível na realidade Mbundo.

A ideia de "fé pela força" era defendida pela Companhia de Jesus, governadores e soldados. Cadornega, repetidas vezes, defendeu que os negros só entenderiam a cruz através dos mosquetes. O arquétipo das Cruzadas compunha os ideais missionários em Angola, onde os cristãos, em nome de Deus e para o serviço da "Santa Madre Igreja" iriam escravizar ou matar os infiéis.

\footnotetext{
${ }^{153}$ Projecto de aforamento de sobas, de Garcia Mendes Castelo Branco, de 1620. Em Cordeiro. Questões histórico-coloniais, vol. I, p. 178

154 História da residência dos padres da Companhia de Jesus em Angola e coisas tocantes ao Reino e conquista. (1/5/1594). Em Brásio. Vol. VI. P.560.

${ }^{155}$ Santos, Eduardo dos. Religiões de Angola. Lisboa, Junta de Investigações do Ultramar, 1969.
} 
Para garantir seus rendimentos econômicos, os missionários articularam, no plano ideológico, o discurso de que a escravidão salvaria o africano visto que o cristianismo o livraria do paganismo e dos ritos perversos. A antropofagia era constantemente mencionada, pois a escravidão seria uma forma de livrar os negros de serem devorados por seus semelhantes. O próprio termo utilizado para a captura de escravos na África revela a dimensão religiosa: resgate. O negro seria resgatado do inferno em que vivia para alcançar as graças do cristianismo através da ação do colonizador branco. "Resgatar" aparece na documentação como sinônimo de escravizar.

A Mesa da Consciênciae Ordem, instituída em 1532, já havia estabelecido as condições legais para a redução à escravidão, tendo por base o direito romano: guerra justa, comutação da pena de morte e extrema necessidade. Era comum que criminosos fossem escravizados ou condenados à pena de morte, o que originou este discurso legitimador:

“A comutação da pena de morte em servidão ou escravidão é uma chance de vida. A escravização pelos cristãos acrescenta à primeira vantagem de uma 'salvação da pena de morte' a segunda de uma 'salvação definitiva' do cristão no paraíso." 156

A "guerra justa" foi evocada como justificativa de se escravizar o povo de Angola, pela grave ofensa que os portugueses sofreram ali. O Ngola havia pedido padres para seu reino e não cumprira a promessa. A prisão de Paulo Dias e do padre Francisco de Gouvéia já justificavam a invasão armada do Ndongo, mas quando o Ngola rompeu com a política de boas relações com o primeiro governador e mandou matar os portugueses em sua corte, ganhou-se toda a legitimação para fazer guerra naquelas terras, cujo produto era sempre escravos. ${ }^{157}$

As práticas tradicionais existentes na África também foram usadas para justificar a escravidão, já que a falta de liberdade para alguns indivíduos era uma instituição muito antiga, como vimos no papel dos ijikus na composição da sociedade Mbundo, que tanto se diferia da escravidão atlântica introduzida pelo europeu.

Em 1593, no auge do conflito dos jesuítas com o governador-geral D. Francisco de Almeida, o visitador Pero Rodrigues explicita os argumentos do uso da escravidão

\footnotetext{
${ }^{156}$ Rocha, Manoel Ribeiro. Etíope resgatado- p. XI

${ }^{157}$ Brásio. Vol. III. p.227-229.
} 
em Angola ao mesmo tempo em que se escusa das acusações "escandalosas" que eram feitas aos religiosos:

"10: não é escândalo nenhum em os padres de Angola pagarem suas dívidas em escravos, porque, assim como na Europa o dinheiro corrente é oiro e prata amoedada, e no Brasil o açúcar, assim o são em Angola e reinos vizinhos os escravos. $2^{\circ}$ : Os escravos que os padres vendem não são somente os que dão o sobas, mas também outros que lhes dão de esmola, ou lhes deixam em testamento, dos quais não têm necessidade para o seu serviço, como quem manda vender trigo e outras coisas, que não há mister para sua casa, a parte onde vale mais. $3^{\circ}$ : Nas alfândegas do Brasil, aonde estes escravos até agora se mandavam, não pagamos direitos por privilégio de Sua Majestade, como também pelo mesmo privilégio não pagam direitos os padres, do açúcar que vendem no Brasil, nem de outras coisas em Portugal. E de usarmos deste privilégio tomaram alguns contratadores motivo de escândalo, e de falarem contra nós em as alfândegas." $" 158$

Carlos Zeron, ao tentar desmistificar a oposição jesuítica à escravidão, constatou que o Privilégio Real dado aos jesuítas dos dois lados do Atlântico, em forma de isenção de tributos para se exportar açúcar e escravos, afirmou a interdependência econômica das missões angolanas e brasileiras, em que os negros africanos foram peças essenciais para o enriquecimento da ordem. ${ }^{159}$

A instituição da escravidão atlântica em Angola foi um complexo processo que envolveu atores de diferentes lugares sociais, articulando a elite local, governo colonial e clero e assim conseguiu criar sua legitimidade.

\footnotetext{
${ }^{158}$ História da residência dos padres da Companhia de Jesus.. p. 554.

${ }^{159}$ Zeron,Carlos. Les jésuites et le commerce d'esclaves entre le Brésil et l'Angola à la fin du XVIe siècle: contribution à un débat. Traverse, 3e année, 1, Zurique, 1996, pp. 34-50.
} 


\subsection{As guerras angolanas: "guerra preta" e Jagas mercenários}

No princípio do século XVII, os governadores abandonaram a ideia de fazer de Angola um entreposto comercial e adotaram uma política de agressão militar contra os centro-africanos. A guerra foi um investimento muito presente no orçamento colonial, não obstante a orientação do rei Felipe III da Espanha (Felipe II de Portugal), que preocupado com os altos custos da guerra, mandou os governadores não se envolverem em atritos e se focarem mais no comércio, pois acreditava que o controle do comércio de escravos, mais do que a guerra, tornaria a colônia sustentável e seria a razão da colonização, de caráter pacífico e pagável.

Mas foi através da imposição pelas armas que os portugueses conseguiram concretizar o tráfico negreiro. O termo "guerras angolanas" foi consagrado por Cadornega e se refere principalmente ao período entre 1580-1660, sendo o período entre 1624-1660 o mais acirrado, cuja principal inimiga dos portugueses foi Nzinga Mbandi.

É claro que a guerra já era bem conhecida entre os habitantes de Angola e havia castas de guerreiros especializados que se dedicavam à proteção do território, fabricação e uso de armas. Antes da chegada dos europeus, os sobados adjacentes ao reino do Ndongo viviam um cenário de instabilidade política e militar, com frequentes invasões por outros grupos e era necessário defender-se. Mas até então, a guerra era feita por demandas de terra, para aumentar a produção agrícola e sustentar o crescimento populacional. Os portugueses perceberam que a guerra era uma forma de se obter muitos escravos rapidamente, já que os perdedores eram tradicionalmente escravizados. E assim, o sentido da guerra foi alterado: o que antes era uma luta necessária para assegurar a sobrevivência do grupo tornou-se uma eficaz ação para o aprisionamento de escravos. Os governos coloniais em Angola passaram a se dedicar fundamentalmente à indústria bélica e nenhum outro setor da economia recebeu tantos recursos como a guerra.

A guerra era um meio eficiente de garantir a sujeição de um soba e, mesmo após o avassalamento, tudo era usado como justificativa para se atacar um sobado: inadimplência no pagamento dos tributos exigidos, aliança com inimigos, insubordinação. Frequentemente e por qualquer razão, os portugueses atacavam sobas que já haviam se avassalado, escravizavam a população - sobretudo a masculina - e 
substituíam os líderes por chefes mais leais ao governo português. Criou-se um ambiente de terror constante em que a obediência era garantida pelo receio das armas.

Thornton se contrapôs à ideia da existência de uma superioridade militar europeia sobre os africanos. ${ }^{160}$ Para ele, antes da revolução industrial, os exércitos europeus não eram tão superiores aos africanos quanto a historiografia sugere. A dificuldade de conquistar o grupo político dominante no Ndongo mostrou aos portugueses a necessidade de combinar táticas, estratégias e armas africanas com as europeias, criando uma "nova arte da guerra em Angola", que foi adotada por ambos os lados do conflito.

Pode-se afirmar que as guerras angolanas foram lutadas por africanos contra outros africanos. Os portugueses eram poucos e inexperientes nos negócios da guerra pelo sertão angolano. Os brancos, chamados mudenlles ${ }^{161}$, que chegavam a Angola não resistiam às intempéries do clima, morriam rapidamente ou, se enviados para o campo de batalha, desertavam e fugiam. Os exércitos portugueses em Angola eram largamente uma força africana sob sua própria estrutura de comando, com europeus simplesmente servindo como generais, como foi documentado por toda a obra de Cadornega. Para compor as tropas, os portugueses contavam com homens dados pelos sobas vassalos, chamados "guerra preta".

A atuação da "guerra preta" foi decisiva para os portugueses vencerem algumas batalhas, pois assim contavam com pessoas que conheciam a geografia local, sabiam como se comportar nas densas matas e como manusear e se defender das principais armas usadas pelos africanos. Havia uma rígida hierarquia militar nestas tropas e seus líderes eram chamados kilambas. Alguns foram premiados por suas ações pelos portugueses, como o Kilamba Mulundo, que aprisionou a irmã de Nzinga, D. Bárbara, e foi considerado "um Deos Marte em quanto negro"162 e prometeu casar uma filha com Ngola Are. Outro kilamba homenageado foi João Bango-Bango, que foi condecorado com o hábito da Ordem de Cristo devido a seus feitos militares na Batalha de Cavanga,

\footnotetext{
${ }^{160}$ Thornton, J. The Art of war in Angola, 1575-1680. Em: Comparative Studies in Society and History, vol. 30. N.02. (Abril, 1988). Pp.360-378.Cabridge University Press.

${ }^{161}$ Cardonega. Vol.I. p. 349.

${ }^{162}$ Cadornega. Vol.I. p.409.
} 
em 1646. ${ }^{163}$ Os filhos de kilambas que iam às guerras eram considerados os mais fiéis entre os gentios. ${ }^{164}$ Os kimbares eram escravos ou pretos forros, treinados militarmente que serviam nos presídios. Cangoandas eram chamados os crioulos de São Tomé e da terra, vestidos “à portuguesa", e eram em torno de 130 homens por volta de $1640 .{ }^{165}$ Os negros empacaceiros eram os que carregavam as armas de pesso, como espingardas e mosquetes, e receberam este nome por alusão aos animais de grande porte, como búfalos e vacas, chamadas mpakassa na língua kimbundo. ${ }^{166}$

Ao mesmo tempo em que a "guerra preta" garantia a vitória dos exércitos prólusitanos, deixava os portugueses em situação vulnerável. Muitos negros desertavam e, em determinado momento da guerra, recusavam-se a cooperar ou passavam a não mais aceitar os maus tratos infligidos pelos comandantes. Assim, a frente de combate lusitano era completamente dependente da força africana.

As guerras em Angola eram primordialmente travadas "mano-a-mano" e assim dependiam muito das habilidades pessoais de cada guerreiro em saber se esquivar, pular, correr, manusear escudos e se esconder rapidamente. Pero Rodrigues anotou que a maior defesa dos soldados africanos "consistia no sanguar que é pular de um lado para o outro com milhares de tranças e tanta agilidade que podia escapar de flechas e espadas." 167

Os exércitos geralmente eram dispostos em "ordem aberta", em que os soldados andavam espalhados e distantes, para dar espaço às habilidades individuais, enquanto uma tropa dava cobertura à outra. Observadores europeus geralmente consideraram este modo de lutar "semi-disperso" como desordem e frequentemente falavam da desorganização dos exércitos africanos. Mas Thornton defende que a desordem era mais aparente do que real, pois as evidências sugerem que os exércitos da África Central

\footnotetext{
${ }^{163}$ Condecoração a João Bango-Bango. Em Brásio. Vol. X. P. 60.

${ }^{164}$ Cadornega. Vol.I. p.397.

${ }^{165}$ Cadornega. Vol.I. p.346.

${ }^{166}$ Cadornega. Vol.I. p.349. nota marginal do autor.

${ }^{167}$ Pero Rodrigues. "História da Residência dos Padres da Companhia de Jesus em Angola e cousas tocantes ao Reino e conquista”,1 de Maio de 1594. Em Brásio. Vol. IV. P. 563.
} 
eram organizados em unidades regulares com uma estrutura de comando e métodos complexos de comandar as unidades. ${ }^{168}$

Os portugueses compreenderam que marchar com o exército formado, tal como se fazia na Europa, era um alvo fácil para as flechas e adargas e passaram a adotar os modelos de guerra africanos. O abandono português da organização que caracterizava as guerras europeias é bem ilustrado pela decisão tomada por Luiz Mendes de Vasconcelos em 1622. O então governador de Angola havia servido no exército espanhol em Flandres e havia escrito um tratado sobre a arte da guerra ("Da arte militar", publicada em 1612). Vasconcelos, vendo o exército formado frouxamente em ordem aberta, deu ordem para que se fechasse, mas foi imediatamente aconselhado que isto deixaria o exército muito vulnerável a flechas e a ordem foi desfeita. ${ }^{169}$

Uma das táticas africanas de maior sucesso nas batalhas era a "meia-lua", em que os mozengos (esquadrões) dividiam-se em três - um central e duas asas - a fim de encurralar o inimigo. Enquanto o opositor lutava contra o mozengo central, os dois outros o cercavam e o aniquilavam. ${ }^{170}$ Pero Rodrigues narrou uma batalha em que as tropas do governador Luis Serrão foram acometidas por esta tática da "meia-lua" em 1589.

\footnotetext{
"o exército de Matamba vinha marchando com muito silêncio, repartido em três muy grossos esquadrões, com seus arcos, e frechas, azagaias e cutelos: por fora dos esquadrões vinha outra infinidade de gente em meia lua muy larga. (...) Após três dias o confronto foi iniciado, atacando-se primeiro o esquadrão do meio, mas os inimigos vinham passando por cima de nossos mortos e ferindo outros tantos, até que se fechou a meia lua, ficado todo o nosso exército cercado entre aqueles esquadrões” ${ }^{171}$.

O conhecimento da geografia local também foi um fator fundamental para as vitórias nas guerras angolanas. Os soldados se escondiam nos matos e dali podiam atacar os inimigos com flechas e adargas sem serem vistos. Cadornega narou que o

${ }^{168}$ Thornton, J. The Art of war in Angola. P.365.

${ }^{169}$ Cadornega. Vol. I. p. 83-86.

${ }^{170}$ Baltasar Barreira ao provincial do Brasil. 17 de Agosto de 1585. Brásio. Vol. III. P. 323-4. Carta de Diogo da Costa, 31 de Maio de 1586, Brásio vol. III. p.336 e Cadornega. Vol.I .p. 406-12

${ }^{171}$ Pero Rodrigues. "História da Residência dos Padres da Companhia de Jesus em Angola e cousas tocantes ao Reino e conquista”.1 de Maio de 1594. Em Brásio. Vol. IV. P. 565.
} 
gentio usava aqueles matos como suas fortalezas, ${ }^{172}$ assim como usavam as pedras para se esconderem, como a pedra chamada de Bamba Ampango, que foi usada pelos Mbundo como fortificação por meses durante o governo de D. Francisco de Almeida. ${ }^{173}$

Havia um complexo sistema hierárquico e de comunicação por sinais, difundidos pelos instrumentos de guerra. A Lunga ou gonguê, instrumento conhecido no Brasil por seu nome yorubá agogô, era um dos principais recursos de comunicação dentro dos exércitos. Constituído de um ou mais sinos de ferro, ao ser batido com um pau, ecoava longe e cada toque alertava os soldados para um momento da batalha: hora de atacar, de marchar ou de recolher, ou sinalizavam a vitória. ${ }^{174}$ Só podia ser tocado pelo capitão mor ou Tendala do reino, ou pelo Samba Tendala na ausência do primeiro. Este instrumento aparece sempre associado aos Jagas como um instrumento bélico e não como instrumento musical.

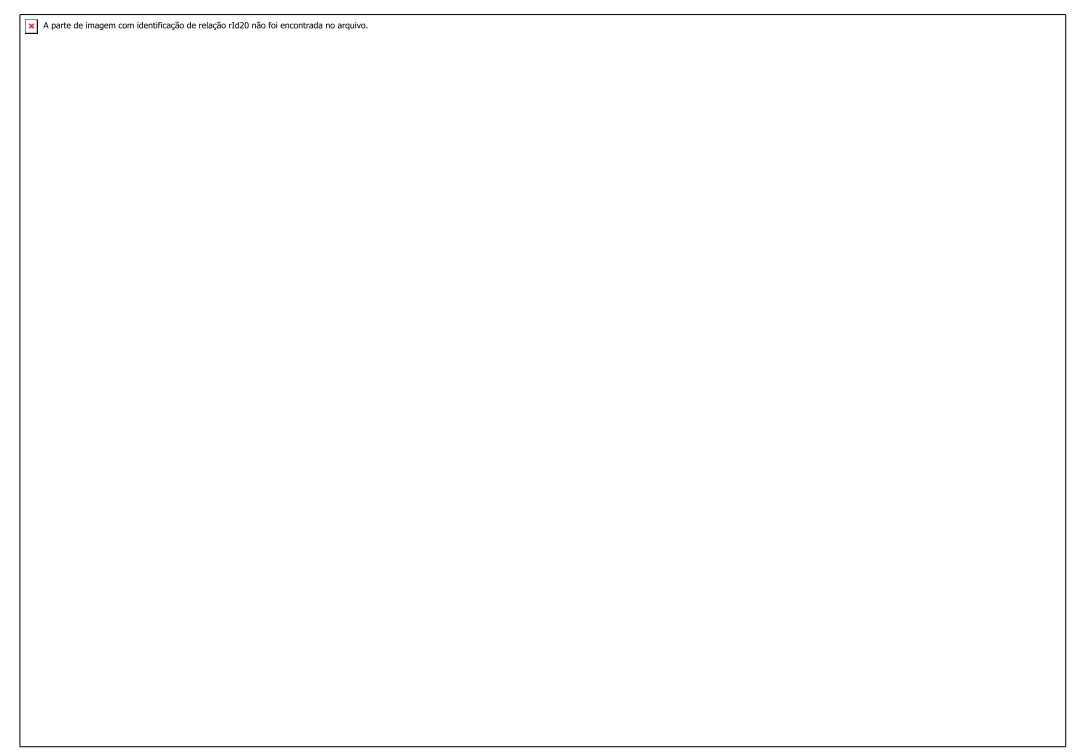

Ilustração em Cavazzi, Histórica Descrição dos três reinos.

\footnotetext{
${ }^{172}$ Cadornega. Vol.I .p. 87.

${ }^{173}$ Cadornega. Vol.I .p. 74.

${ }^{174}$ Pero Rodrigues. "História da residência dos padres da Companhia de Jesus...”. Brásio.Vol. VI.P.574.
} 


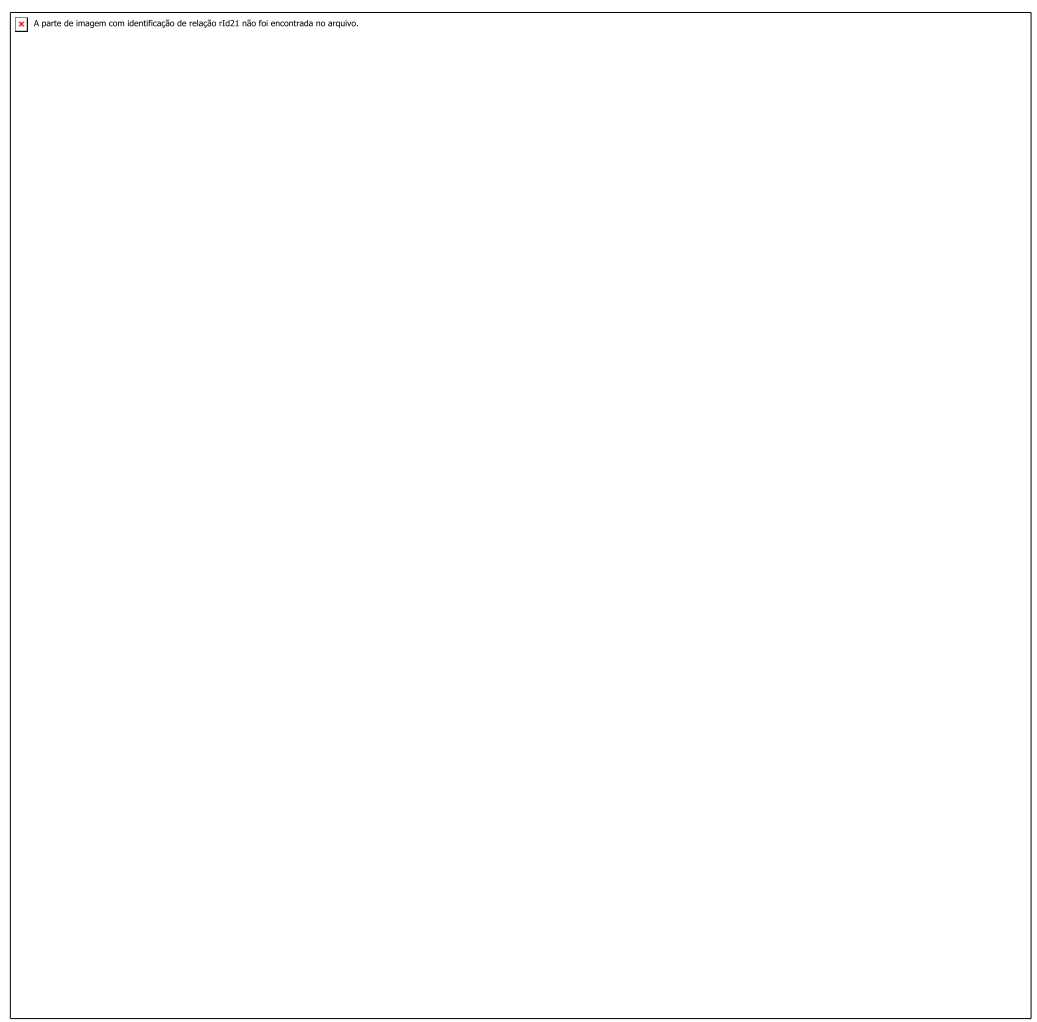

Aquarela do Manuscrito Araldi de Cavazzi publicada em Alencastro. Trato dos viventes.

Escrito em italiano: "Lunga é instrumento militar dos Jagas e sua principal insígnia, sem o qual não podem ser Jagas".

Tambores e caixas também aparecem acompanhando os soldados nas batalhas, em que um tocador motivava os guerreiros pelos toques enérgicos. Os tambores - de uma forma geral chamados Ngoma nas línguas bantas- eram considerados sagrados e seus toques eram capazes de mobilizar forças ancestrais. Nas guerras eram utilizados para evocação dos espíritos que ajudavam a vencer as batalhas, além de manterem os guerreiros no mesmo ritmo e pulsação. Cada ocasião demandava um toque e somente os principais comandantes eram autorizados a tocá-los. Uma tradição recolhida por Miller narra o momento em que Kinguri, em busca de magia adicional para vencer seus oponentes no Libolo, mandou um de seus companheiros irem a Lunda e lhe trazer uma das insígnas dos chefes tubungu, um tambor de guerra chamado ngoma ya mukamba, que era um grande talismã de guerra. As aquarelas de Cavazzi frequentemente mostram os tambores acompanhando os cortejos militares e os rituais Jagas. 

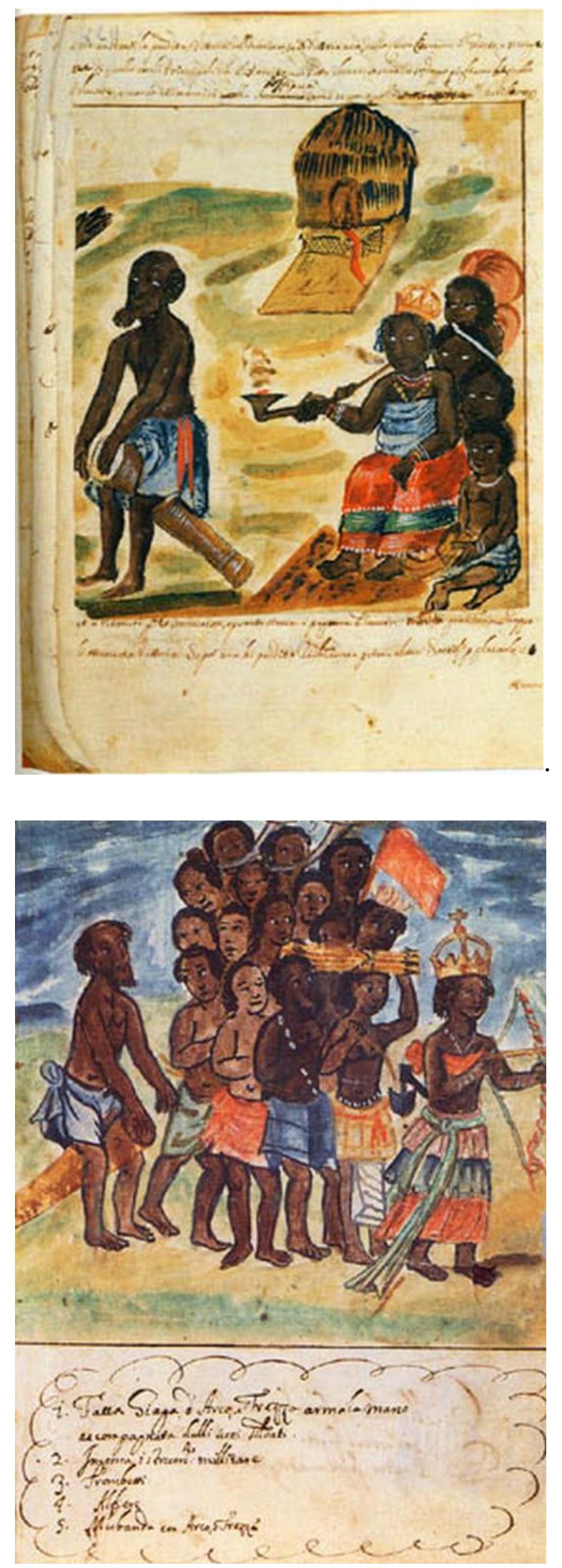

Aquarelas do Manuscrito Araldi de

Cavazzi, publicada em Pantoja, Selma. Nzinga Mbandi: mulher, guerra e escravidão. 
Uma importante característica dos exércitos da África Central é que eles eram inteiramente compostos pela infantaria. Apesar de a cavalaria ter sido adotada com eficácia em sistemas militares africanos ocidentais, ${ }^{175}$ os cavalos nunca chegaram a desempenhar papéis decisivos nas guerras na África Central, não obstante os esforços dos portugueses para isto. ${ }^{176} \mathrm{O}$ relevo acidentado e a hidrografia composta por diversos rios caudalosos impedia a circulação dos cavalos, de forma que as travessias eram feitas a pé. A cavalaria teve que ser substituída por pombos, tropas especiais formadas por soldados levemente armados conhecidos pela habilidade de correr rapidamente. ${ }^{177}$

A ausência de cavalos e animais de carga gerou efeitos na logística dos exércitos angolanos, que tinham que carregar todo o suprimento nas costas, auxiliados apenas pelo transporte fluvial em alguns trechos. O serviço de carregador era um dos mais essenciais para a guerra e, ao mesmo tempo, o mais desprezado pelos africanos, que se recusavam a realizá-lo e muitas vezes abandonaram os portugueses, deixando para trás toda a bagagem, chamada quicumba. Apesar de Cadornega se referir à quicumba como "mulherio e gente inútil", ${ }^{178}$ Thornton a considerou a "chave objetiva para qualquer batalha”. ${ }^{179}$ A quicumba correspondia não apenas às coisas, mas todo o aparato de utensílios e pessoas necessárias para o trânsito em guerra, como alimentos, armas, estrutura de acampamento e para alimentação. Cerca de metade do contingente militar era de carregadores, ${ }^{180}$ incluindo muitas mulheres, talvez "esposas" dos combatentes, que ajudavam no preparo da comida e outros serviços. Oficiais portugueses acreditavam

\footnotetext{
${ }^{175}$ Law, Robin.The horse in West african history: the role of the horse in the societies of pre-colonial West Africa.London, 1980.
}

${ }^{176}$ Carta de Fernão de Sousa ao governo. 8 de Janeiro de 1630. Em Heintze, 1988. p. 243. Doc. 149. Fernão de Sousa defendia a criação de uma companhia de cavalos, com capitão e alferes, para defesa dos rebeldes e socorro da conquista. E no "Memorial de Luiz Mendes de Vasconcelos". 1616. Em Brásio. Vol.VI.p.21. Vasconcelos pedia ao rei que lhe enviasse 200 cavalos, considerados fundamentais para o comércio. E na "Consulta do Conselho Ultramarino". 14/12/1652. Em Brásio. Vol. XI . doc. 79. Ordenava a importação de cavalos do Brasil, mas chamava atenção para que nunca se levasse éguas a Angola, para evitar a reprodução e a conseqüente posse desses animais pelos africanos.

${ }^{177}$ Cadornega. Vol. I.p.89, 148, e Relatório de Fernão de Sousa em Heintze, 1985. P.252-55.

${ }^{178}$ Cadornega. Vol. I.p.135, 347, 403.

${ }^{179}$ Thornton, J. The Art of war in Angola. P.369.

${ }^{180}$ Um observador da Batalha de Ambuíla notou que o exército do Congo lavava metade de carregadores e metade de soldados. "Relação da mais gloriosa victoria..." 1666. Em Brásio. Vol. XII, p. 584. 
que a presença feminina também ajudava a preservar a moral e dava aos soldados algo extra para se lutar, pois se os soldados adversários fugissem, suas mulheres poderiam ser retidas pelos vitoriosos. Contudo, os oficiais tentavam limitar o número de mulheres nas expedições, especialmente as não casadas.

A decisão de carregar a quicumba e onde colocá-la no momento da batalha era fundamental para a vitória do exército. A Batalha de Cavanga, em 1646, ilustra bem esta importância, pois o conselho de guerra português, na véspera da batalha, gastou tempo considerável decidindo onde deixar a quicumba e finalmente optou por deixá-la bem no meio do exército ao invés de destacar tropas para defendê-la, prejudicando assim seu desempenho no campo de batalha. ${ }^{181}$ Em outras guerras, os inimigos roubavam toda a quicumba, deixando as tropas desoladas, sem comida, armas e abrigo em lugares desertos. O roubo da quicumba foi frequentemente usado como estratégia de ataque para desestabilizar o oponente.

A alimentação das tropas era outro fator fundamental na logística da guerra em Angola. A chamada "farinha de guerra" foi essencial para a nutrição dos soldados, mas não conseguia garantir a sobrevivência de todos nas longas jornadas. Frequentemente homens da "guerra preta" eram deslocados para a tarefa de buscar alimentos nas matas, chamado canzar ${ }^{182}$, o que era demandava que se percorresse kilometros, às vezes dias, para encontrar comida, enquanto o resto da tropa padecia de fome. A busca por alimentos fragilizava o exército que tinha seu contingente diminuído, como ocorreu em1644, quando Nzinga Mbandi atacou o exército português quando estavam em busca de comida. ${ }^{183} \mathrm{~A}$ busca por comida limitava o tamanho dos exércitos e a fome era frequente e determinante, já que sem alimentos os soldados não conseguiam lutar. Frequentemente, os exércitos assaltavam as comunidades e roubavam toda a comida.

Cavazzi registrou o estrago que os exércitos faziam ao passarem por comunidades rurais, ${ }^{184}$ e quando passavam por territórios aliados, as tropas eram

\footnotetext{
${ }^{181}$ Cadornega. Vol. I. 403-407.

${ }^{182}$ Do verbo Kukanza, apanhar frutos pendentes. Em Cadornega. Vol. I. 349.

${ }^{183}$ Cadornega. Vol. I. 347-348.

${ }^{184}$ Cavazzi. Histórica Descrição dos três reinos... Vol.I. P. 316
} 
orientadas a ter cuidado redobrado para não roubarem comida e prejudicarem as relações amistosas. Os sobas aliados tinham a obrigação, prevista pelo acordo de vassalagem, de alimentar as tropas, mas os abusos de soldados famintos muitas vezes desagradavam os sobas e prejudicava as alianças, de forma que Fernão de Sousa recomendou muito cuidado neste particular a seu capitão Bento Banha Cardoso, em $1626 .{ }^{185}$

As armas de fogo usadas pelos europeus foram, por muito tempo, consideradas pela historiografia como avassaladoras e revolucionárias nas guerras na África. Mas estudos que investigaram este cenário mais de perto colocaram estas afirmações em cheque, argumentando que as armas de fogo tiveram um pequeno efeito na tentativa portuguesa de conquistar Moçambique, justo no mesmo tempo em que as guerras angolanas começaram. ${ }^{186} \mathrm{Se}$ os portugueses que lutaram no Congo em 1491 levavam armas de fogo, os congoleses foram indiferentes à sua performance, pois o equipamento mandado ao Congo em 1509 continha apenas lanças e arcos. Thornton afirma que o período entre 1450 e 1650 foi considerado um dos momentos de mudança nas guerras europeias, em que a infantaria, paulatinamente, substituía a cavalaria armada com lanças. ${ }^{187}$ A utilidade das armas de fogo europeias em Angola foi questionada, pois as condições para seu emprego eram menos favoráveis. O poder das armas de fogo, tão úteis contra a cavalaria com armadura, era um desperdício contra inimigos sem blindagem, mais ainda, sua inutilidade não era apenas uma desvantagem nas batalhas contra tropas em massa, era uma dificuldade ainda maior contra as formações dispersas tão comuns em Angola. Talvez a maior vantagem das armas de fogo fosse psicológica, pelo menos naqueles encontros onde o povo nunca tinha ouvido ou visto uma arma de fogo. Lopes-Pigaffetta creditou ao barulho das armas portuguesas a vitória sobre os

\footnotetext{
${ }^{185}$ Regimento a Banha Cardoso, 1626. Em Heintze. Fontes para a história de Angola. Vol. I.p.205

${ }^{186}$ Gray, Richard. "Portuguese Musketeers on the Zambezi". Em: Journal of African History, 12:4 (1971), pp. 531-33

${ }^{187}$ Thornton, J. The Art of war in Angola, 1575-1680. P. 372.
} 
Jagas. ${ }^{188}$ Pero Rodrigues escreveu que os africanos que tinham no princípio fugido das armas de fogo, estavam agora as roubando das mãos dos portugueses. ${ }^{189}$

Apesar de mosquetes terem alcançado algum êxito nos exércitos portugueses, as armas africanas (arcos e flechas, lanças, facas, machadinhas e grandes escudos) continuaram a serem as preponderantes nas guerras angolanas. Thornton sugere que a maior vantagem que os europeus trouxeram para a África foi a armadura de corpo e as habilidades com a espada. A armadura e a espada fizeram deles uma infantaria pesada e temida, mas o poder destas armas não começou sem desvantagens. A armadura era pesada e a mobilidade das tropas era estritamente limitada por ela. Mais anda, não podia ser sustentada no campo sozinha. Em situações que foram obrigadas a lutar sozinha, ou porque os aliados haviam abandonado ou porque a infantaria leve havia fugido, foram esmagadas, frequentemente por um homem apenas. Foi o que ocorreu na batalha de Ngolomene a Kweta, em 1644, quando tropas leves estavam em busca de Nzinga e seu exército acometeu os homens vetidos de armaduras pesadas.

Desde o início da presença portuguesa em Angola, a organização no campo de batalha português foi formada para se conformar ao modelo de seus oponentes. Em 1585, Baltazar Barreira defendeu o recrutamento de arqueiros e soldados locais, que somou 9000 efetivos, enquanto os portugueses totalizavam apenas $300 .{ }^{190}$ As tropas locais, que Diogo da Costa chamou chorimbares (quimbares ou imbari) lutaram com seu "próprio estilo". ${ }^{191}$ Além do mais, um dos temas comuns de Cadornega e uma das razões para ter escrito sua "História" foi a incompetência dos oficiais europeus recémchegados que não entendiam a situação local- a arte da guerra local- e perdiam batalhas e tropas como resultado.

O desenvolvimento de uma "nova arte da guerra" em Angola revela algumas complexidades da história militar no mundo pré-industrial e mostra as dificuldades em ver como as conquistas europeias na África foram feitas. Concordamos com Thornton

\footnotetext{
${ }^{188}$ Lopes-Pigaffetta. P. 61

${ }^{189}$ Pero Rodrigues. "História da Residência dos Padres da Companhia de Jesus em Angola e cousas tocantes ao Reino e conquista”,1 de Maio de 1594. Em Brásio. Vol. IV. P. 565.

${ }^{190}$ Baltasar Barreira para o provincial do Brasil. Em Brásio. Vol. III. P.323.

${ }^{191}$ Carta de Diogo da Costa, 20 de julho de 1585. Em Brásio. Vol. III. P. 319-20.
} 
ao afirmar que não havia superioridade organizacional nem técnica esmagadoras ou automáticas dos europeus sobre os africanos, apesar dos sistemas militares de ambos os lugares terem sido afetados pelo contato. ${ }^{192}$

Além da "guerra preta", kimbares, kilambas, cangoandas, os portugueses receberam um apoio decisivo nas guerras de aprisionamento de escravos pelo interior: os guerreiros Jagas-Mbangala.

Enquanto os bandos Jagas destruíam comunidades, desorganizavam a produção agrícola, pilhavam os bens que possuíam e sequestravam seus membros, os portugueses prosseguiam com a guerra pelo interior, construindo fortificações ao longo do rio Kwanza e organizando feiras a fim de aumentar o volume do tráfico de escravos. Juntos formaram uma lucrativa e violenta parceria que provocou grande despovoamento na região de Angola.

Nos registros de Battell, conta-se que em 1600, mercadores vindos de Luanda estabeleceram contatos com os Jagas perto do porto de Benguela, onde haviam destruído grande parte do reino e feito muitos cativos, que lotaram os navios portugueses. ${ }^{193}$ Por volta de 1607 , o reino de Benguela foi efetivamente destruído por estes bandos e as terras do poderoso Kafuxe foram pilhadas, o que serviu para abastecer o recém fundado presídio de Cambambe com muitos escravos.

O Governador Manuel Pereira Forjaz (1607-1611) ilustra bem o descompasso entre ordem metropolitana e política colonial para o enriquecimento pessoal. Forjaz recebeu instruções para implementar um governo de "paz e justiça" através da diplomacia. ${ }^{194}$ Para compensar as perdas das guerras, o rei estimulava a agricultura comercial como açúcar ou a pesca das conchas nzimbu, usado como moeda no Congo. As ordens régias não foram cumpridas, ao contrário, o governador articulou uma extensa rede comercial que envolvia a guerra para aprisionamento e venda de escravos, e lhe rendia altos lucros. Pereira Forjaz organizou o comércio de escravos e marfim

\footnotetext{
192 Thornton, J. The Art of war in Angola, 1575-1680. P. 377.

${ }^{193}$ Ravestein. Op. Cit.p.16-21.

${ }^{194}$ Regimento a Manuel Pereira Forjaz, 26/3/1607. Brásio, Vol. 5.p. 270. A mesma idéia foi repetida nos regimentos passados a governadores posteriores. Regimento de 22/9/1611, que se supõe ser dirigido a Francisco Correia da Silva, que nunca foi a Angola, Brásio vol, 6 p.21-39; e Regimento a João Correia de Sousa, 3/9/1616, Brásio vol. 6. p.257-9.
} 
conectando a região do Mpumbu (nordeste do Congo) aos portos de Mpinda (Loango) e Benguela. Tudo isso se valendo dos ataques Jagas aos povoados, onde os homens eram escravizados e os meninos raptados. O governo fomentou a guerra entre as populações locais para se tornar grande exportador de escravos. Pereira Forjaz fortaleceu Cambambe como centro comercial, de onde se podia explorador novas rotas comerciais para o leste, "até sonhando em alcançar Moçambique na outra costa". ${ }^{195}$ Assim ações militares passam a assumir lugar de primeira importância nos planos governamentais.

Bento Banha Cardoso, um soldado veterano que estava em Angola desde 1592, assumiu como governador interino em 1611 após a inesperada morte de Pereira Forjaz. Bento Banha Cardoso fez a primeira aliança formal com os Jagas, inaugurando uma política de guerra. Banha Cardoso também descumpriu as instruções reais que requeriam governos pacíficos e argumentou que "levou a guerra a grandes escalas para trazer vassalos desobedientes novamente ao controle português e reabrir as rotas para o comércio". 196

Banha Cardoso atacou o soba Xilonga do Lukala, formalmente vassalo dos portugueses, alegando que este se tornara desobediente e bloqueara o comércio; ergueu o forte de Hango nas terras de Hango a Kikaito, líder da facção norte do Ndongo; ordenou uma campanha ao longo do Kwanza, a leste do forte de Cambambe, atacando as terras de Dembo a Pebo e Pungo a Ndongo na província do Ari. ${ }^{197}$

O governador sofreu devassa em que teve que justificar seus atos perante a Coroa. Defendeu-se junto ao governo real alegando que havia trazido mais de 80 sobas para o controle português, garantindo tributos em escravos e assim, a continuidade dos mercados. Ele assinalou que não apenas adquiriu escravos pela guerra, mas que também impôs tributos em escravos às novas terras anexadas. ${ }^{198}$

Devido aos sucessos de suas campanhas militares, a Coroa fez "vistas grossas" às violações das instruções reais e decidiu apoiar as guerras em Angola. Escolheu o

\footnotetext{
${ }^{195}$ Catálago dos governadores de Angola. Em Corrêa, Elias Alexandre da Silva. História de Angola. Lisboa: Agência Geral das Colônias, 1937. 2v. Vol I, p. 221

${ }^{196}$ Processos de justificaçãodos Actos de Bento Banha Cardoso, 31/10/1616. Em Felner. Angola. p.438.

${ }^{197}$ Devassa de Bento Banha Cardoso, 21/8/1615. Arquivo Histórico Ultramarino, CX. 1, Doc. 40. Cartas de Bento Banha Cardoso. 28/6/1614. Em Brásio. Vol. VI. p. 178.

${ }^{198}$ Processos de justificação dos Actos de Bento Banha Cardoso, 31/10/1616. Em: Felner, Angola. p.438 e Cadornega, Vol. I. p.77
} 
fundador do forte de Cambambe, Manuel Cerveira Pereira, para governar dando continuidade às guerras iniciadas por Banha Cardoso. Cerveira Pereira foi enviado a Benguela para estabelecer ali um novo reino e conseguir mais escravos para a Coroa. ${ }^{199}$

Com a ajuda dos kilombos Mbangala, Cerveira Pereira lançou uma violenta campanha contra Kakulu Ka Hango. Após esta guerra, suas forças se dirigiram para o nordeste, em direção ao vale do Zenza, onde pilharam os chefes independentes Ndembos. ${ }^{200}$ Os lucros da venda de escravos obtidos nesta guerra engordaram os cofres para a conquista de Benguela e para o próprio enriquecimento do governador.

Cerveira Pereira, ao se estabelecer em Benguela, falhou em firmar uma aliança com os bandos Mbagala do sul, pois de acordo com os estudos de Miller, a instituição do kilombo teria surgido entre os Ovimbundos desta região, e sendo assim, estes povos estavam mais estruturados ali e não precisavam buscar aliados externos para enfrentarem a população local, como acontecia na porção norte do Ndongo, onde atacavam os povos Mbundo. ${ }^{201}$ Os Mbangala do sul recusavam o comércio com os Portugueses e o pagamento de tributos. "Viviam em abrigos rochosos fortificados, onde armazenavam água e comida para suportar os cercos.",202

\footnotetext{
${ }^{199}$ Manuel Cerveira Pereira para o rei. 11/3/1612. Em Brásio vol. VI. p.77-81.

200 "Catálago dos governadores de Angola. Em Corrêa, Elias. História de Angola. Vol I, p. 224. E Luis M. de Vasconcelos ao rei. 28/8/1617. Em Brásio. Vol. VI.p. 238

${ }^{201}$ Miller, J. Poder político e parentesco. p.210. E Representação a Manuel Cerveira Pereira. 2/7/1618. Em Brásio vol. VI. p. 315-19.

${ }^{202}$ Relação da Costa de Angola e Congo, pelo ex-governador Fernão de Souza, 21/2/1632. Em Brásio vol. VII. p. 129.
} 


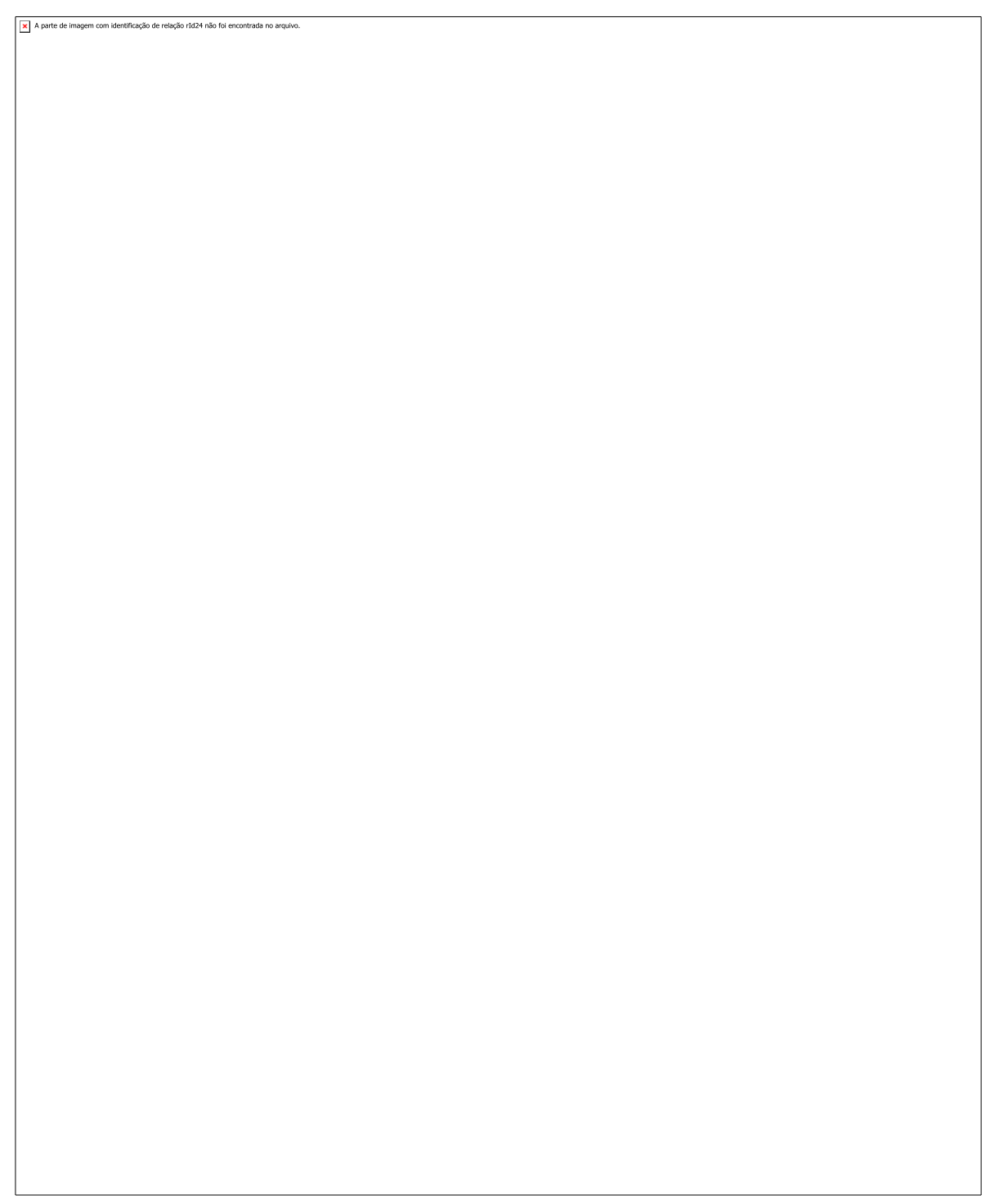

Em Miller. Poder político e parentesco. P. 211

Após a partida de Cerveira Pereira de Benguela em 1617, a Coroa escolheu Luiz Mendes de Vasconcelos para sucedê-lo como governador de Angola, cumprindo mandato até 1621. Vasconcelos foi para Angola com objetivo de regulamentar o tráfico negreiro revertendo para a Coroa os impostos de exportação, porém a necessidade de se fortalecer militarmente para derrotar Ngola Mbandi fez com que o governador também se aliasse aos Jagas.

Antes de sua chegada a Angola, Vasconcelos acreditava que escravos poderiam ser gerados por ações militares e chegou a escrever que "o comércio de escravos, que é 
tão importante para o tesouro de Sua Majestade, poderia ser escassamente mantido, porque na ordem do tráfico ser satisfatório, é necessário ter as armas em punho". ${ }^{203}$

Em seu plano inicial, Vasconcelos propunha o uso das táticas tradicionais européias para vencer estas guerras e denunciava o uso dos Jagas, "muito contrários ao serviço de Deus e de Sua Majestade", especialmente porque eles tinham sido usados como "cães farejadores para injustamente traze-los (os habitantes locais) como escravos." Ele antevia que a estratégia de usar continuamente os Jagas "em algum tempo consumiria os nativos deste reino em um caminho que levaria a despovoamento." 204

Inicialmente contrário a aliança com os Jagas, percebeu que a extraordinária força militar que eles conseguiam mobilizar rapidamente poderia lhe ser útil para ameaçar o Ngola. A tradição oral recolhida por Miller narra o momento em que Kulaxingo, chefe Mbangala chamado pelos portugueses de Jaga Cassanje, se apresentou ao governador Vasconcelos oferecendo apoio para lutar contra o Ngola: explicou que o régulo tinha construído uma fortaleza mágica que os portugueses eram incapazes de atingir e assim o governador precisaria das armas mágicas do dito Jaga. ${ }^{205}$ Esta narrativa reforça a crença dos Jagas- Mbangala de que a sorte na guerra dependia também da manipulação de apetrechos mágicos.

Miller afirmou que a conquista portuguesa só ocorreu, ainda que parcialmente, devido ao apoio dos Mbangala. Neste ponto, concorda Thornton que afirmou que a aliança com bandos Mbangala foi chave para o "rápido e dramático sucesso das forças portuguesas" ${ }^{206}$. Os governadores lusos exploraram as rivalidades entre facções do norte e do sul no Ndongo, para capturar escravos ao longo dos rios Lukala e Kwanza. No século XVII, a tecnologia militar européia não representava superioridade, ao contrário, eram os Mbangala e a organização em kilombos que eram decisivos para garantir a vitória. $^{207}$

\footnotetext{
${ }^{203}$ Memorial de Luis Mendes de Vasconcelos, 1616. Brásio. vol. VI. p. 264

${ }^{204}$ Luiz Mendes de Vasconcelos ao rei. 28/8/1617. Brásio. vol. VI. p. 283-4.

${ }^{205}$ Miller. Poder político e parentesco. p. 196.

${ }^{206}$ Heywood eThornton, J. Central africans...p. 114

${ }^{207}$ Miller, J. Poder político e parenteco. P.197.
} 
Em tempos pacíficos, os Jagas capturavam os agricultores locais para serem vendidos como escravos e, em tempos de guerra oficialmente declarada, juntavam-se às expedições portuguesas. Havia uma relação de complementaridade entre os interesses Jagas e portugueses: enquanto os Jagas preferiam guardar os rapazes mais novos ainda não submetidos à circuncisão das linhagens para serem iniciados nos rituais dos kilombos, os portugueses se interessavam por homens e mulheres adultos para serem escravizados na América. Para Miller, "os Mbangala tornaram-se, assim, a ambivalente pedra basilar que sustentava os dois braços do duplo do sistema comercial que atingiu a fase de maturidade durante a primeira parte do século dezassete". ${ }^{208}$

Em consequência da parceria econômico-militar entre portugueses e Jagas, um grande empório de escravos se desenvolveu nas proximidades do médio Lukala. Como os Jagas conseguiam capturar mais escravos do que era absorvido pelos canais oficiais do governo, paralelamente desenvolveu-se um sistema ilegal do tráfico. A aliança entre o governo português e Jagas gerou uma contradição no sistema colonial, pois muitos sobas invadidos pelos bandos guerreiros ficavam incapacitados de saldarem o tributo em escravos exigidos pela coroa.

Rebello de Aragão, enviado por Felipe III em 1618 para avaliar a posição de seu exército em Angola, deu parecer de que, inicialmente, tal aliança foi fundamental para a colônia e para o estabelecimento do tráfico negreiro, porém os Jagas tornaram-se arrogantes e começaram a desviar escravos que deveriam ter ido para a alfândega real em Luanda. O emissário atribuía a culpa do tráfico ilegal não apenas aos africanos, mas também aos oficiais portugueses que encorajavam o rapto da população local. ${ }^{209}$ Os chefes Jagas eram tratados com grande dignidade pelos oficiais lusos. A relação de Garcia Mendes Castelo Branco argumentava que o rei português deveria oferecer três tonéis de vinho por ano aos Jagas para garantir sua lealdade e o lucrativo tráfico de escravos que eles proporcionavam. ${ }^{210}$

Contudo, as alianças com os Jagas eram sempre flutuantes e eram guiadas mais por seus interesses momentâneos do que por laços de fidelidade. Em diversos momentos, os

\footnotetext{
${ }^{208}$ Idem.p. 195

${ }^{209}$ Rebello de Aragão. Relação. Em: Cordeiro, Luciano. Viagens, explorações e conquistas dos Portugueses. Colleção de documentos. Lisboa, 1881.

${ }^{210}$ Relação de Garcia Mendes de Castelo Branco. Ajuda,16 de Janeiro de 1620. Em: Brásio. Vol. VI. pp. 446-452.
} 
mesmos líderes Jagas que serviam aos portugueses os atacavam em batalhas posteriores. O próprio Jaga Cassanje, que ajudou o ataque ao Ndongo em 1617, passou a ser considerado um dos principais inimigos dos portugueses.

Cadornega narrou episódios em que os Jagas acompanhavam os exércitos portugueses. Em sua narrativa cronologicamente confusa, registrou o momento que os Jagas Caza e Donga abandonam os portugueses e passam a lutar ao lado da rainha Nzinga:

"Nesta ocazião do Cerco da Fortaleza de nossa Senhora da Asumção da Embaca accompanhou tambem o tenente General o Jaga Donga com seu Quilombo o qual servia debaixo de nossas bandeiras, como o fazia tambem como dito he o Jaga Caza, o qual, tendo-nos assistido à Conquista do Dongo com o Governador e Capitão geral, se rebellou o que obrigou ao Governador (...) a dar as ordens necessárias por ser cauza de muita importância o afastarse-nos este poderozo Jaga e tambem se havia rebelado outro Jaga por nome Caza". ${ }^{211}$

Miller acredita que os Mbangala rejeitaram "o papel de mercenários empregados exclusivamente pelo governador de Angola e tinham voltado ao seu papel original, como agentes de comerciantes privados." 212 De qualquer forma, a ação predatória dos Jagas para o aprisionamento de escravos pelo interior gerou grandes lucros aos governadores e agentes envolvidos no tráfico negreiro e causou grande despovoamento na região de Angola.

\footnotetext{
${ }^{211}$ Cadornega. História Geral das Guerras Angolanas. Vol. I. p. 90

${ }^{212}$ Miller,J. Poder político e parentesco. P.196.
} 
MAPA IX. Os Imbangala e os Portugueses (c.1600-1650)

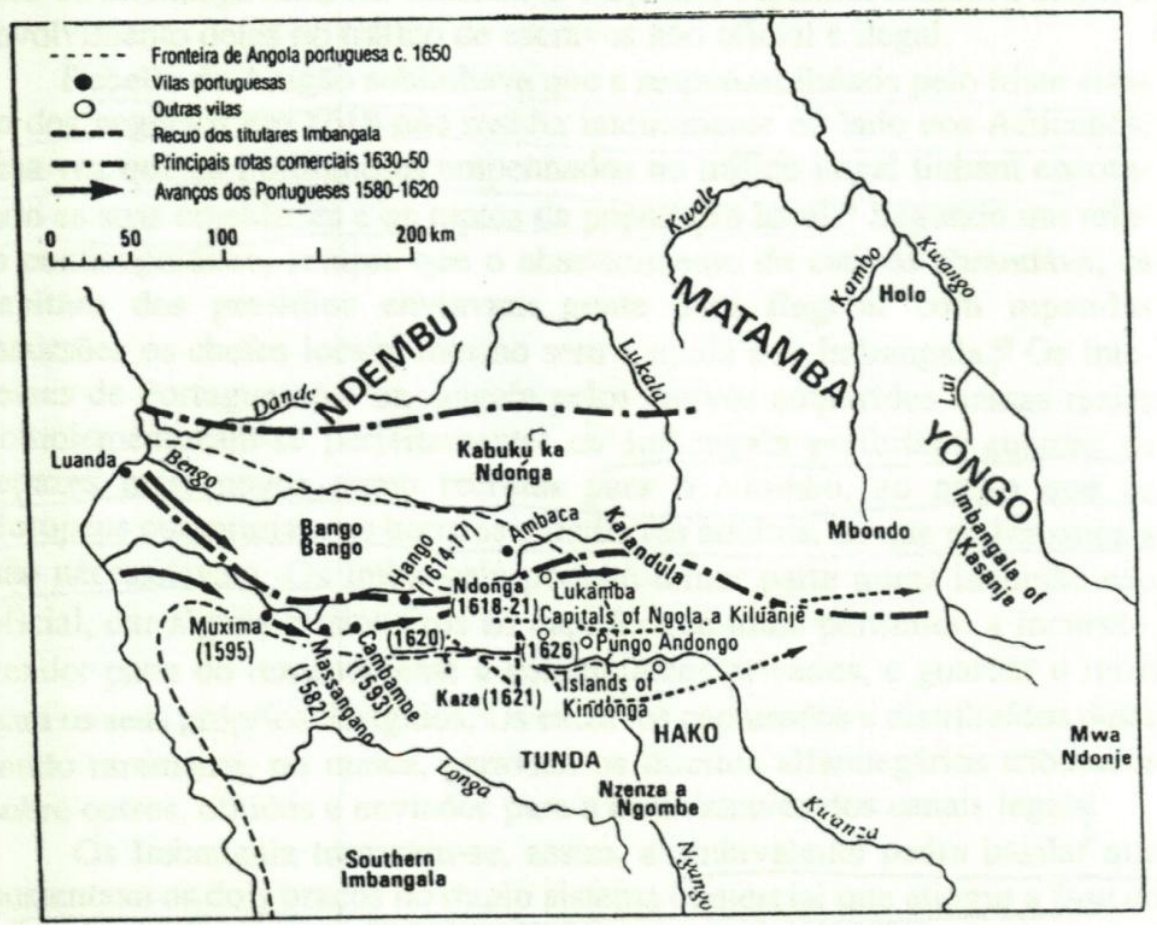

Alianças dos Mbangalas com os portgueses. Em Miller. Poder político e parentesco. P. 193.

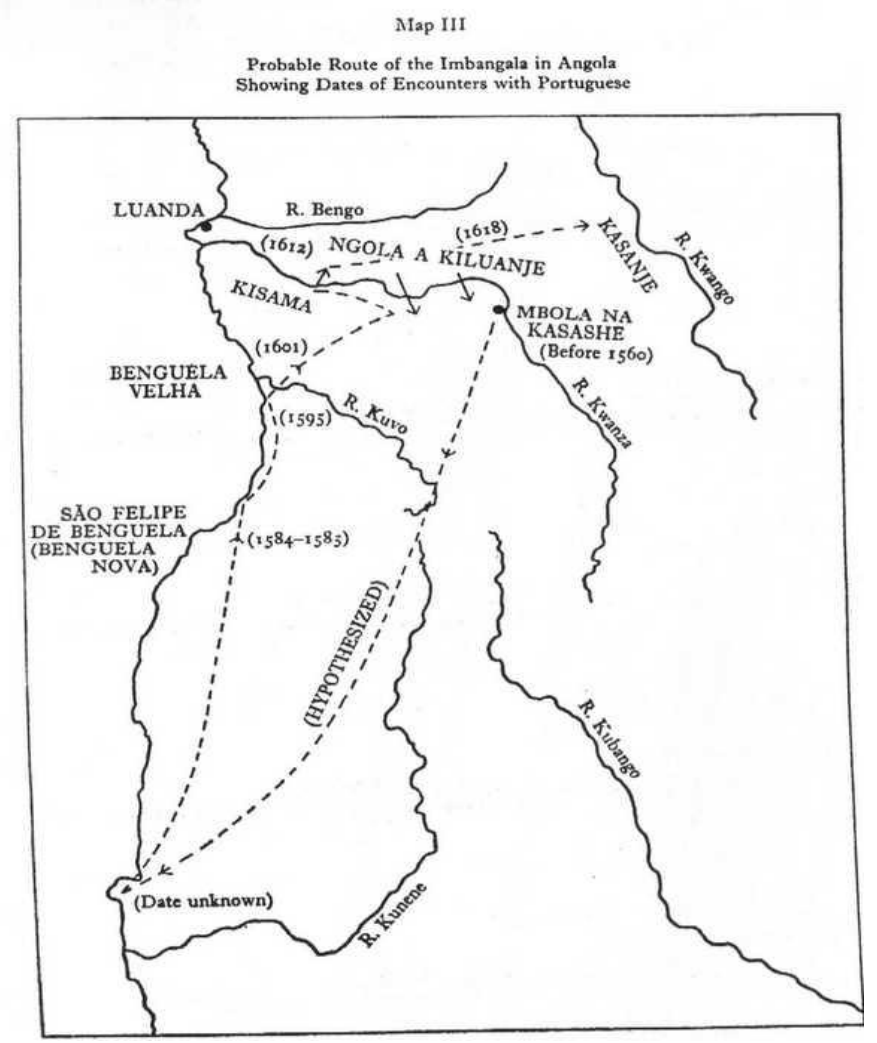

Provavéis rotas dos Mbangala em Angola, mostrando as datas dos encontros com os portugueses. Em Miller. The Imbangala and the cronology of Early Central African History. 


\title{
2.4. Itinerário do tráfico negreiro: feiras e presídios
}

O comércio já existia no reino do Ndongo e era bem desenvolvido quando os portugueses chegaram. As feiras, chamadas kitanda na língua Kimbundo, faziam parte de uma rede ampla que conectava diferentes povos e mercadorias da África Central. Cadornega registrou o hábito do comércio entre o povo com o qual conviveu em Angola:

\begin{abstract}
"são muito inclinados a feiras, e para comprarem barato e venderem caro, tem tantas manhas que nenhuma nação lhes faz ventagem. Dinheiro em metal não corre entre elles, tudo he comutação, dando huma cousa por outra. Em algumas feiras comprão mantimentos por capões, em outras por pedras de sal. Os portugueses comprão as cousas meudas por empondas, que são terças de palmilhas. Nas feiras comprão peças por panos de preço, por tafetá, damasco, veludo, alcatifas, margarideta, vinho e outras mercadorias de Portugal e da Índia." 213
\end{abstract}

Para Jan Vansina, antes da chegada dos portugueses coexistiam dois tipos de comércio na África Centro-ocidental: o de "curta distância", essencialmente regional, conduzido nos mercados locais, ligava as comunidades vizinhas, e o "comércio à distância”, que ocorria entre povos culturalmente diferentes, conectando estados e regiões diversas. ${ }^{214}$ A partir do século $\mathrm{XV}$, o contato com os portugueses teria gerado um novo tipo de comércio, o de "longa distância", em que produtos europeus eram trocados por produtos africanos.

Adriano Parreira, orientado por Vansina, complementou seu professor alegando que as viagens na África Central eram medidas mais em tempo do que em distâncias, em função das condições climáticas e a instabilidade dos caminhos, sendo estas noções de "curta" ou "longa" distância imprecisas e variáveis. Parreira formatou o "Quadro das distâncias entre regiões, aglomerados populacionais, mercados e lugares", 215 dando a distância, ora em dias e ora em léguas, entre as principais localidades de Angola. O grande esforço de Parreira em cruzar os dados de diversas fontes fornece um instrumental para o historiador atual, mas apenas confirma a imprecisão dos números, por exemplo: de Luanda a Mbanza Kongo se percorria 80 a 100 léguas, 270 milhas ou

\footnotetext{
${ }^{213}$ Cadornega. Op.cit.p. 32.

${ }^{214}$ Vansina,Jan. "Long distance Trade- routes in Central Africa”.The Journal of African History.Vol.III, n³, 1962.P. 375

${ }^{215}$ Pareira, Adriano. Economia e sociedade em Angola na época da Rainha Jinga. (Século XVII). Lisboa: Editorial Estampa, 1997. Pp.90-93.
} 
18 dias. Os documentos europeus foram escritos para relatar, dar ciência e informações aos conquistadores, com o intuito de facilitar a ação dos próximos que fossem ao local, mas a cada experiência registraram-se diferentes dados, tornando quase inútil o esforço de sistematizar as distâncias entre as localidades da África Central.

Beatrix Heintze classificou em "mercados locais", que ocorriam na maioria dos sobados, e "mercados supra-regionais" espalhados por todo o território, procurados por pessoas de diferentes localidades. ${ }^{216}$ Os produtos africanos mais estimados nos mercados do Ndongo eram o sal, o óleo de palma e as peles de animais, enquanto os produtos europeus mais desejados eram as missangas de vidro, bebidas alcoólicas, armas de fogo e pólvora, que eram trocados por cobre, marfim, ferro lavrado, cera e escravos. Os panos recebiam especial atenção, tanto os de origem africana como os europeus e indianos.

Havia rotas comerciais já consolidadas antes da chegada dos europeus, a partir de vias terrestres, fluviais e marítimas. O transporte por terra encontrava vários obstáculos, como a vegetação que cortava a pele dos caminhantes, animais ferozes e a grande quantidade de rios para atravessar, o que dificultava o uso da tração animal. Assim, o transporte das mercadorias dependia essencialmente dos carregadores, a maioria escravos, que cortavam a pé as regiões da África Central levando os produtos sobre os ombros ou cabeças. O transporte de pessoas importantes também era feito pela tração humana, em tipoias, e os escravos eram amarrados e arrastados por todo o trajeto.

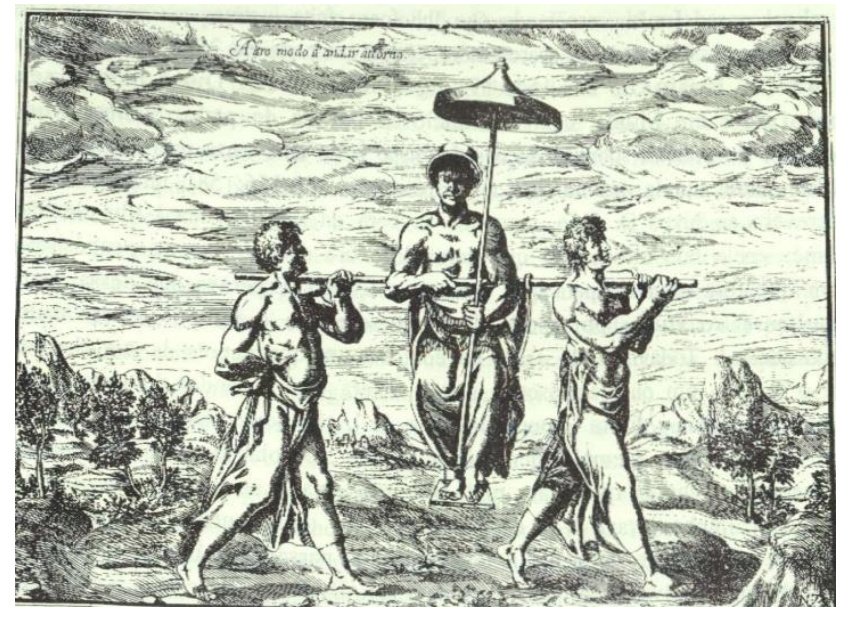

Carregadores. Em Cavazzi. Descrição histórica. Vol. II. P. 186.

\footnotetext{
${ }^{216}$ Heintze, B. Angola nos séculos XVI e XVII. P.200.
} 
Os rios eram muito utilizados no transporte de cargas e pessoas, principalmente o rio Kwanza, que desaguava próximo a Luanda, conectando o interior ao litoral. A navegação pela costa era praticada e conectava os portos de Luanda, Benguela, Mbriz e Mpinda.

Nas principais passagens e fronteiras, cobravam-se taxas alfandegárias para se atravessar rios e terras, que eram chamados xikaku. Estes direitos movimentavam a economia da região, mas sobrecarregavam os comerciantes, que deveriam pagar também pelas mercadorias transportadas, e foram alvo de protestos por parte deste setor. $^{217}$

No momento da chegada dos portugueses já havia uma densa rede de comunicações, constituída por vias terrestres, fluviais e marítimas que formavam a base de toda a atividade econômica na região entre os rios Zaire, Kwango e Kuvo. ${ }^{218}$ Praticava-se um comércio ativo entre regiões distanciadas e havia rotas comerciais que ligavam lugares remotos, com grande número de paragens intermediárias. Os comerciantes europeus já encontraram um sistema de trocas organizado e usaram as rotas comerciais pré-existentes para inserirem seus produtos nos mercados africanos.

Em 1582, a feira "supra-regional" mais importante acontecia na capital Cabaça, sob a supervisão do Ngola, e era visitada por pessoas dos mais diversos lugares. ${ }^{219} \mathrm{~A}$ mercadoria mais procurada pelas diversas caravanas era o sal, proveniente da Quissama principalmente. Inspetores do Ngola, inspirados por um modelo que já existia no Congo desde 1526, passaram a controlar a venda de pessoas escravizadas nas feiras de Cabaça e adjacências, zelando para que não fossem vendidas pessoas livres, o que era punido com pena de morte. 220

Frequentemente havia rebeliões nas feiras e o consequente encarecimento dos escravos, sobretudo devido à ação de comerciantes brancos que interceptavam as "peças" nos caminhos, impedindo-as de chegar às feiras. Assim os mercadores negros

\footnotetext{
${ }^{217}$ Cadornega. Vol.III. p.274.

${ }^{218}$ Parreira. Op.cit.p.77.

${ }^{219}$ Relação de 1582-1583. Brásio. Vol.III p. 227.

${ }^{220}$ Brásio. Vol.III. p.146 . 7/11/1576.
} 
passaram a mudar sua trajetória e abandonavam as feiras já consolidadas para irem venderem os escravos em outros lugares. Esta situação levou o rei da União Ibérica, em 1607 a proibir que homens brancos fossem às feiras e fizessem resgates de escravos e também exigiu mais rigor nas punições a extorsões e "maus ofícios". ${ }^{221}$

Junto às feiras, a construção de fortalezas e presídios impulsionava a colonização portuguesa rumo ao interior, pois garantia a estabilidade das negociações comerciais e marcava militarmente a presença lusa nas regiões conquistadas. As fortalezas serviram também para armazenar alimentos e escravos que aguardavam caravanas para o litoral, onde seriam embarcados para o tráfico Atlântico.

Segundo Junia Furtado, a construção de fortalezas fazia parte das estratégias colonizadoras no Império Português e era bastante comum nos séculos XVI e XVII. ${ }^{222}$ O próprio regimento passado a Paulo Dias de Novais pelo rei D. Sebastião determinava que o primeiro governador de Angola deveria erguer "três fortalezas de cal e pedra entre os rios Zenza e Lucala". ${ }^{223}$

Buscamos analisar o itinerário da penetração portuguesa, refletindo como os portugueses utilizaram as rotas comerciais existentes para interiorizar a colonização de Angola. Os portugueses escolheram locais estratégicos para se fortificaram, estabelecendo-se em regiões produtoras das mercadorias mais estimadas, em torno das principais feiras, em pontos cruciais para o escoamento do tráfico negreiro.

\section{São Paulo de Luanda}

Em 25 de janeiro de 1576, Paulo Dias fundou a vila de São Paulo de Luanda e mandou erguer a primeira estrutura defensiva de Angola, a fortaleza de São Paulo de Luanda, dedicada a São Sebastião. O padre Baltazar Barreira defendeu a fortificação em terra firme, pois temia que o rei do Congo se incomodasse com a construção de um forte na ilha Luanda, que lhe pertencia. ${ }^{224}$

\footnotetext{
${ }^{221}$ Regimento ao governador de Angola (Manuel Pereira Forjaz) em 26/03/1607. Brásio. Vol.VII .p. 274.

${ }^{222}$ Furtado, Junia. Sons, cores e formas e movimentos na Modernidade Atlântica: Europa, América e África. Belo Horizonte: EDUFMG, 2008.

${ }^{223}$ Regimento a Paulo Dias de Novais. Em Brásio. Vol. IV. p. 302.

${ }^{224}$ Carta do Padre Baltazar Barreira. Em Brásio Vol. VI. Pp.617-618
} 
O local da vila foi escolhido pela existência de um ótimo porto natural que se formado pela baía da ilha de Luanda.Recebia as águas dos rios Kwanza, ao sul, e do Bengo, ao norte. Nas proximidades da vila havia uma importante fonte de água potável, o poço da Maianga- então chamado Lagoa dos Elefantes. O morro de São Paulo era outro ponto estratégico na ocupação territorial pois dá vistas para o mar e está ligado ao plateau que dá acesso ao interior. Ali se instalou a primeira sede do governo português e foram construídas as estruturas administrativas, como a Câmara e o tribunal, e o povoamento foi se dirigindo para a "cidade alta".

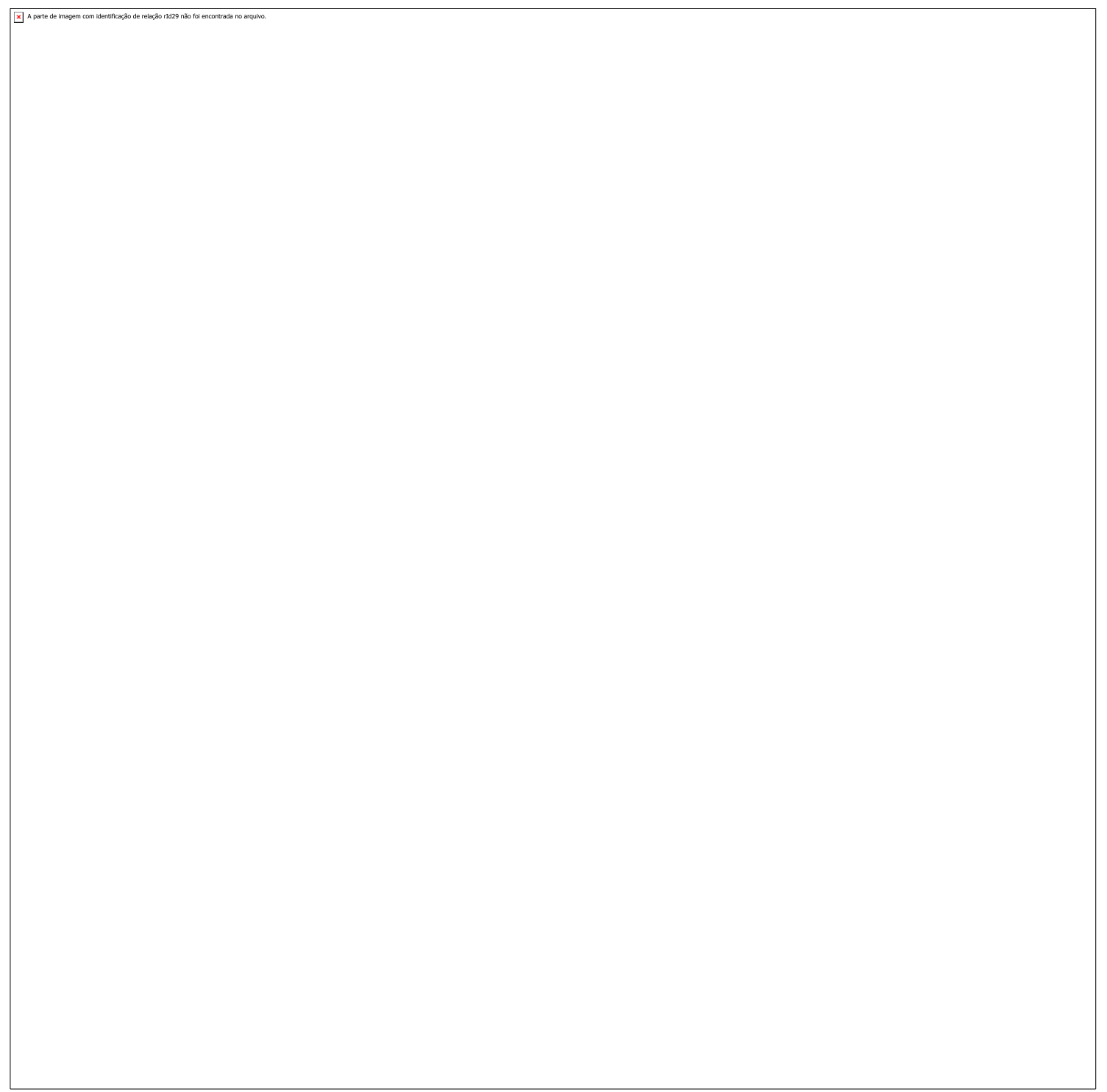

A ilha de Luanda em um mapa de Gerardo Mercatos em: http://pt.wikipedia.oarg/wiki/Luanda. Acesso em junho de 2012. 
Mais ainda em 1606, Manuel Cerveira Pereira, ao relatar à Coroa a situação dos fortes da conquista, reclamava que há muito tempo o forte de Luanda estava sem defesa alguma, com a artilharia sem reparos e não havia ordens nem recursos para melhor guarnecê-lo. ${ }^{225}$ Uma descrição de 1608 também denunciava o mal estado daquilo que nem poderia se chamar feitoria "porque são uma taipas feitas de palha, estas mui desbaratadas". 226

A fragilidade do forte e a falta de recursos não evitou o ataque dos holandeses em 1641 que tomaram conta do porto de Luanda e consequentemente do escoamento do tráfico negreiro até 1648. Após a expulsão dos holandeses por Salvador de Sá, teve o seu nome trocado para São Miguel, santo da particular devoção do "restaurador".

\section{Muxima}

A primeira fortaleza fora do litoral foi a de Muxima, localizada na província da Quissama, onde se retirava o sal, a mercadoria de maior prestígio e importância nas feiras do Ndongo. A maior parte do sal utilizado no Ndongo era proveniente das grandes minas da Ndemba, localizadas na Quissama. Os sobas da Quissama tradicionalmente forneciam sal ao Ngola como pagamento de tributos, reconhecendo a soberania deste titular. O controle político da região da Quissama era estratégico para controlar economicamente a região, já que o sal era um produto essencial para aquelas comunidades. O padre Pero Rodrigues, visitador da Companhia de Jesus, registrou que "das minas de prata fazem pouco caso, as de sal são o seu tizouro por ser moeda corrente com que comprão peças e todo gênero de mantimentos." 227

Pensando no controle das rotas do sal, Paulo Dias de Novais ergueu a fortaleza de Muxima em 1581. Não por coincidência, em terras do primeiro soba a se avassalar, Muxima Quitambonge. Localizada às margens do rio Kwanza, Muxima significa coração, entranhas, por estar bem no centro do reino do Ndongo, em ponto bastante estratégico.

Os habitantes da Quissama aparecem sempre como "gente belicosa e mais ferós que há neste Reyno, pelejão em campo com muito esforço e ás vezes pegão em

\footnotetext{
${ }^{225}$ Caderno do governador de Angola. 17/10/1606. Em Brásio. Vol. VII. P.224-225.

${ }^{226}$ Descrição de Angola. 1608. Em Brásio. Vol. VII.p. 389.

${ }^{227}$ História da residência dos padres da Companhia de Jesus. Em Brásio. Vol. VI. P.571.
} 
espingardas sem temor da morte". ${ }^{228}$ Foram grandes opositores à presença portuguesa e frequentemente atacavam as embarcações lusas estacionadas no Kwanza e dificultavam o comércio na região, muitas vezes impediram as passagens e a navegação do Kwanza e tomaram os escravos dos portugueses. ${ }^{229}$ Pela continuidade destes ataques, percebemos que a dita "conquista" da Quissama não ocorreu de fato, como foi exaltada no governo de Paulo Dia de Novais. A província e seus habitantes nunca foram efetivamente dominados. A construção da fortaleza de Muxima não significou a subjugação da população ao seu entorno, mas certamente colaborou para a penetração no interior, permitindo que a "conquista" portuguesa se estendesse até a província da Ilamba. Da fortaleza, que guarnecia de armas e mercadorias a região, saíram diversas expedições em socorro das tropas que atacavam sobados inimigos, tendo importância fundamental na defesa contra os povos da Quissama, que insitiam em atacar a fortificação.

Em 1599, o governador João Furtado de Mendonça determinou a construção de uma nova fortificação para melhor defesa do presídio. Nesta época, o presídio oferecia suporte às relações comerciais na região, servindo como ativo entreposto de mercadorias e escravos.

Cadornega registrou que em sua época se podia ver as ruínas de uma outra fortaleza, erguida nas terras do Soba Catala, que dava continuidade à dita "conquista da Quissama”, mas que se desmanchou em pouco tempo. O presídio de Muxima foi transferido para novo local em 1609 por determinação do governador Manuel Pereira Forjaz,que temia os contantes ataques dos povos da Quissama.

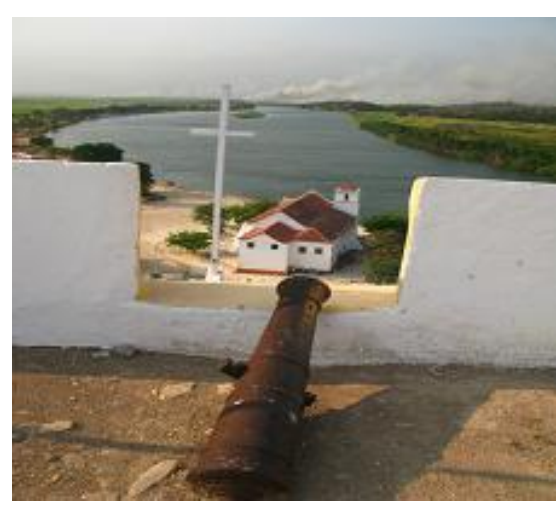

Fortaleza de Muxima. Fonte: http://angolaterranossa.blogspot.com/2011_01_01_archive.html. Acesso em fevereiro de 2012.

\footnotetext{
${ }^{228}$ Brásio. Vol. VI. P.550.

${ }^{229}$ Cadornega. Vol. I. p.80
} 


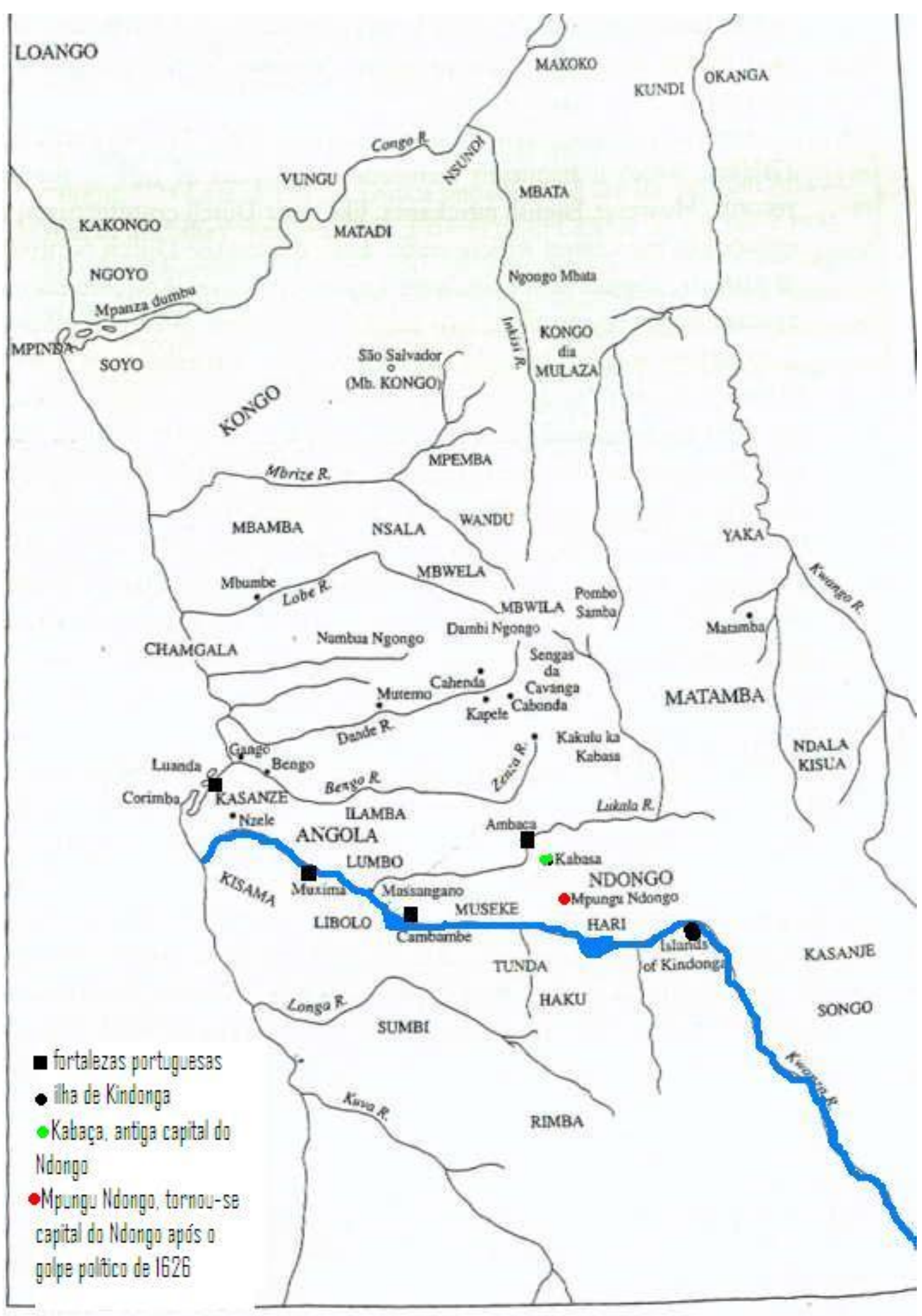

West Central Africa

Fortalezas portuguesas erguidas nos séculos XVI e XVII ao longo do rio Kwanza. Edição do mapa de Heywood e Thornton. Central africans, Atlantic creoles and the foundation of the Americas, 1585-1660. 
Cambambe

As lendárias minas de prata da região de Cambambe motivaram várias investidas pelo interior. Os jesuítas constantemente exaltavam as riquezas de Angola em suas correspondências. Os trechos a seguir mostram como os religiosos buscaram convencer as autoridades da importância do investimentona colonização do território angolano, reforçando o chamado "mito da prata":

\begin{abstract}
"Sobretudo há muitas minas de prata e muito ricas. Eu vi o sítio onde elas estão e tive nas mãos pedras que de lá trouxeram e entre elas vinham muitos fios, alguns mais grossos que alfinetes dos grandes, muito grossos, tanto que os mineiros afirmam que até agora se não têm outras minas descobertas tão ricas. Dizem eles mesmos que por cada quintal de pedra responderá oitenta marcos de prata. Isto é ainda à flor da terra, obra de uma vara; e afirmam os negros que há minas em que tudo é prata sem pedra, e estas minas são muitas." 230
\end{abstract}

"Em todas estas serras há muitas minas de quase todos os metais e querem dizer que, como o reino for sujeito a Portugal, que se acharão minas de ouro, principalmente no Musseque, que é a mais rica terra de todas. Aqui estão as minas de prata de Cambambe, que são as mais ricas que os portugueses até agora têm achado. Estas minas são serras altas e muito compridas de penedias, e não luzem por fora como lá imaginam, são como as do Reino, somente têm veias de prata, as quais, quanto mais cavam, tanto mais tiram maior quantidade e melhor prata; destas veias há muitas que parecer ser impossível acabarem-se nunca; minas tão ricas, que tão somente os ferreiros do rei sabem onde estão e, quando querem tirar para el-rei, acham vergas tão grossas que não lhes fazem outro benefício senão martelá-las e ajuntá-las umas às outras, de que fazem malungas, e levam-nas ao rei. Dando-nos Deus paz, facilmente se achariam."231

Diogo de Raquena, mineiro espanhol, nos tempos de Dom Sebastião, visitara as minas de Cambambe, de onde tirou amostras de prata e mandou ao rei. Além desta mina, teria descoberto outras quarenta minas também de prata. No ano de 1590, Martin Rodrigues de Godoy, mineiro de Sua Majestade, explorou ao longo do rio Lucala, aonde teria achado muitas minas de prata, de que trouxe amostras, fez ensaios e concluiu ser realmente prata. ${ }^{232} \mathrm{Na}$ História da residência dos padres da Companhia de Jesus, justifica-se o fato destas minas não terem até então sido exploradas:

"como quer que o benefício das minas requeira quietação, e até agora neste reino não a houve por ser o gentio buliçoso e os portugueses poucos, sem presídios nem povoações que possam conservar as províncias lá conquistadas, ficam sempre enterrados tão

\footnotetext{
${ }^{230}$ Carta do padre Diogo da Costa, de 20 de Julho de 1585. Em Felner. Angola no século XVIdocumentos. P. 155.

${ }^{231}$ Carta do padre Diogo da Costa ao Provincial de Portugal, 31 de Maio de 1586. Em Felner.Angola no século XVI-documentos. P. 162.

${ }^{232}$ Brásio. Vol. VI. P.550.
} 
grandes tesouros, com os quais poderá enriquecer Portugal muito mais que com as drogas que lhe vêm de outros reinos." ${ }^{, 233}$

Após a ruptura de Nzinga Ngola com Paulo Dias de Novais, no princípio da década de 1580, o primeiro governador apressou-se em marchar em direção a Cambambe, visando conquistar as supostas minas de prata pela força.

O sonho da prata de Cambambe continuou alimentando a ambição dos governadores e motivou Manuel Cerveira Pereira (no seu primeiro mandato, 16031606) a construir a fortaleza de Nossa Senhora do Rosário de Cambambe em 1604. O padre Fernan Guerreiro, noticiou a construção da fortaleza:

"Este novo governador (Manuel C. Pereira) entrando no cargo e continuando a jornada de seu antecessor, em poucos dias entrou pela terras do negro Cafunche fazendo-lhe guerra e lhas assoulou quási todas. Deu-lhe três batalhas e o desbaratou, escapando ele porem. Dali foi logo à serra de Cambambe, onde estão as minas de prata. Fez logo uma fortaleza num sitio para isso acomodatissimo. Poz logo na fortaleza 250 soldados e começou a cavar, ainda que pouco em algumas partes daquela serra, de que tiraram varias mostras de prata que nella há, que dizem os mineiros ser muita e haver tambem outros metais." 234

A vitória sobre o soba Cafuche Cambare foi um importante passo para a conquista da região de Cambambe, pois Cafuche havia derrotado os governadores anteriores que quiseram afrontá-lo, e estas vitórias lhe fizeram tão poderoso que até o Ngola lhe temia. Dizia-se que caberia a Cafuche assumir o título Ngola segundo as leis de sucessão daquele reino, por ser tão valente e capaz de vencer os portugueses. ${ }^{235} \mathrm{Com}$ a fuga de Cafuche, muitos sobas que antes eram subjugados por ele vieram à obediência dos portugueses e até o Ngola mandou uma embaixada ao governador português para parabenizar pelo ataque, já que Cafuche era tão temido por todo o Ndongo.

A fortaleza de Cambambe foi erguida em local alto e estratégico, junto à parte navegável do Kwanza, possibilitando assim a conexão com o litoral e o fácil guarnecimento do forte. A partir de Cambambe, os portugueses fomentavam as guerras entre os grupos, chamadas guerras de Kwata-Kwata, em que os centro-africanos iam à busca de escravos em outras povoações.

\footnotetext{
${ }^{233}$ História da residência dos padres da Companhia de Jesus em Angola e coisas tocantes ao Reino e conquista (1/5/1594). Em Felner. Angola no século XVI. p. 177.

${ }^{234}$. Relações annuaes das cousas que fizeram os Padres da companhia de Jesus, nos annos de $1602 e$ 1603. Escrita pelo padre Fernan Guerreiro. Em Brásio. Vol. VII. P. 53.

235. Idem. Ibdem.
} 


\section{Massangano}

Após a ruptura da paz entre Paulo Dias e o Ngola, os governadores rodavam a província de Cambambe em busca da prata. A luta direta contra o Ngola era considerada impossível já que o soberano reunia milhares de guerreiros, enquanto os portugueses eram poucos, não mais de 150 soldados. Os sobas aliados aos portugueses temiam o confronto e desertaram. Apenas o soba Songa, que recebera o nome cristão de Paulo Novais, auxiliou seu homônimo.

A batalha contra as poderosas tropas do Ngola ocorreu no dia 2 de fevereiro de 1583, num sábado, dia da purificação de Nossa Senhora. A vitória dos portugueses foi considerada milagrosa e foi entendida como uma mercê de Nossa Senhora, que com sua santa mão, ajudara seus filhos a vencer o potente inimigo. Cadornega registrou o "milagre" revelando o olhar teocêntrico de sua época. As vitórias portuguesas eram entendidas como obras da "mão de Deus" que ajudava o exército português a concretizar a luta do bem contra o mal, pois a presença portuguesa em Angola era uma luta também espiritual em seu benefício. Percebe-se em seu discurso a identidade entre luta militar e luta espiritual, sendo o exército luso o exército de Deus, mantendo a visão cruzadista das batalhas.

Após a vitória milagrosa, os portugueses batizaram a localidade de Villa da Victoria de Massangano e Paulo Dias mandou erguer a fortaleza de Massangano em 1583. Entre as margens direita do rio Kwanza e à esquerda do rio Lucala, em local elevado depois do ponto em que os dois cursos d'água se unem, possibilitava assim a observação da navegação em ambos os rios. Foi erguida, junto à fortaleza, uma igreja dedicada a Nossa Senhora da Victoria, a quem se atribuia a vitória dos portugueses em 1580 e neste local foi sepultado o corpo de Paulo Dias de Novais, morto ali em maio de 1585 .

Com a fortificação de Massangano, os portugueses melhoraram sua defesa e expandiram a ocupação da região de Cambambe. Além de marcar a presença militar portuguesa, a partir deste estabelecimento tentava-se garantir a integridade das redes comerciais, em que o tráfico de escravos assumia papel cada vez maior. Ao redor do presídio, desenvolveu-se uma povoação que atuava tanto na guarnição militar como nas feiras que ocorriam na região. 
Durante a ocupação holandesa, Massangano foi usada como refúgio para o governo portugues e, com Luanda tomada, passou a servir como capital politica e adminsitrativa até 1648.

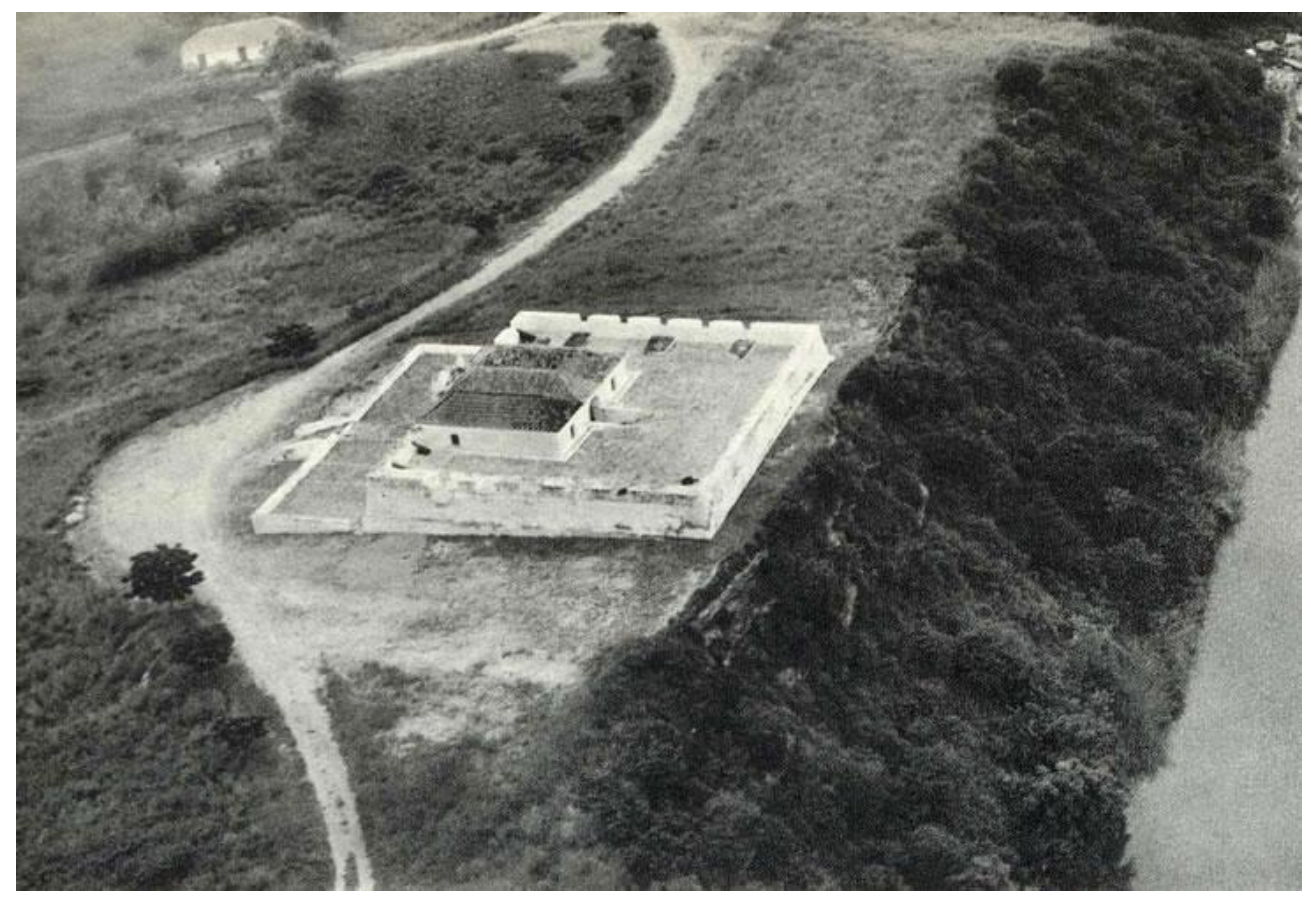

Fortaleza de Massangano. Imagem da década de 1990.

fonte:

http://www.minhasimagens.org/Fconvidados/historiaestorias/chinguar/cuanza/cuanza.html, acesso em fevereiro de 2012.

Ango

Ao assumir o governo interino em 1611, a primeira empresa que se ocupou Bento Banha Cardoso (1611-1615) foi combater os sobas da província do Lumbo que impediam a "real feira de peças", de importância considerável naquele momento. Após muitos conflitos com vários sobas da região, Banha Cardoso decidiu erguer uma fortaleza para garantir a segurança daquela feira e controlar os sobas levantados da província do Lumbo. Deu o nome da fortaleza de Ango (Hango ou Haco), por ser o nome do maior soba daquelas terras. ${ }^{236}$

${ }^{236}$. Cadornega. Vol. I. p. 77-78. 
Quando Luiz Mendes de Vasconcelos assumiu o governo de Angola em 1617, determinou a conquista do Ndongo, que compreendia "a Província do Ari, Pedras de Mapungo e Mauzondo e sítio de Cabaça", ${ }^{237}$ para assim trazer o recém-instalado Ngola Mbandi à obediência do rei de Portugal.

Luiz Mendes de Vasconcelos determinou a construção de um presídio em Ambaca, em terras muito próximas à Cabaça, capital do reino do Ndongo. Decisão que ameaçou a soberania e desagradou profundamente Ngola Mbandi, desencadeando uma intensa guerra. O episódio ficou conhecido como guerra contra o Ndongo e marcou o processo de perca da independência deste reino. A retirada portuguesa de Ambaca passou a ser uma as maiores reivindicações do Ngola e seus representantes na década de 1620. Apesar de acordada, a retirada nunca foi efetivada, ao contrário, os portugueses fortaleceram sua presença na região com a abertura da feira de Ambaca em 1624. O que no princípio não passava de um entreposto sem importânciae difícil abastecer ${ }^{238}$, tornou-se ponto estratégico para o domínio politico do Ndongo e passou a ser um centro fundamental da irradiação da "cultura atlântica-criola." 239

Percebemos que a construção de fortalezas em locais estratégicos foi o modo pelo qual o governo português avançava pelo interior e aumentava seus domínios na conquista de Angola. Através destas fortificações, os portugueses puderam se estabelecer no território, controlar as feiras e guarnecer militarmente as regiões ocupadas, aumentando assim o poder de defesa contra os inimigos, principalmente os habitantes locais que se opunham à presença portuguesa. A construção de uma nova fortaleza significava um passo adiante na conquista de Angola.

\footnotetext{
${ }^{237}$ Cadornega. Vol. I. nota marginal do autor. P. 83.

${ }^{238}$ Fernão de Sousa ao governo. Em Heitze, 1988. Nesta carta o governador Fernão de Sousa mostra-se favorável a desocupação de Ambaca.

${ }^{239}$ Heywood, Linda e Thornton, John.Central africans, atlantic creoles, and the fondation of the Americas, 1585-1660. Cambridge: Cambridge University Press, 2007.
} 


\section{Capítulo 03. Nzinga Mbandi e a luta pelo Ndongo}

\subsection{A guerra contra o Ndongo}

Luiz Mendes de Vasconcelos assumiu o governo de Angola em 1617 com o objetivo de regulamentar o tráfico negreiro e reverter para a Coroa os impostos de exportação. Vasconcelos chegou justo no ano de falecimento de Nzinga Ngola Kiluanje, e julgou que a sucessão do Ndongo seria o momento oportuno para subjugar o reino e Ngola Mbandi, recém-instalado no poder. O novo cenário político no Ndongo motivou Vasconcelos a decidir rapidamente pela guerra, pois desejava aumentar sua participação no comércio de escravos ${ }^{240}$.

Vasconcelos era um experiente combatente nas guerras ibéricas no Oriente e dedicou-se à produção intelectual sobre a guerra através do tratado "A arte militar", publicado em 1612. Ao ser indicado para o governo de Angola, Vasconcelos defendia que para manter satisfatoriamente o comércio de escravos era necessário ter as armas em punho. ${ }^{241}$ Sua família, principalmente seu sogro, o comerciante cristão novo Manuel Caldeira, estava diretamente envolvida com o tráfico de escravos para as Índias espanholas. ${ }^{242}$ Como o novo governador não tinha esperanças de que a Coroa pudesse aumentar seu ordenado ou mandar mais recursos para seu governo, optou pela "autoajuda financeira". 243

O pretexto para a guerra contra o Ndongo foi a rebelião do soba Caita Calabalanga (Kaita Ka Balanga ou Gaita) contra o comandante da fortaleza de Ango, Francisco Antunes da Silva. Ao invés de atacar diretamente o soba Caita, o governador optou por atacar Ngola Mbandi, porque este tinha incitado o soba, seu aliado, contra os portugueses e lhe prestara auxílio militar. O governador acreditava que vencendo o adversário mais poderoso derrotaria todos os seus aliados menores.

As duas residências reais do Ndongo - Vunga e Cabaça - foram queimadas e destruídas, membros da família real foram feitos reféns, sobas que estavam sob a jurisdição do Ngola foram avassalados e muitos kijiku foram aprisionados. Ngola

\footnotetext{
${ }^{240}$ Heintze. Angola nos séculos XVI e XVII. p. 293.

${ }^{241}$ Memorial de Luiz Mendes de Vasconcelos, 1616. Em Brásio. Vol. VI. P.264.

${ }^{242}$ Alencastro, Luiz Felipe. O trato dos viventes. P. 357.

${ }^{243}$ Heintze. Angola nos séculos XVI e XVII. p. 293.
} 
Mbandi conseguiu escapar e refugiou-se, primeiramente em Samba Aquizenzele, na fronteira leste do Ndongo. ${ }^{244}$

Visando ameaçar a soberania do Ngola, João Mendes de Vasconcelos decidiu transferir o presídio de Ango, construído por Banha Cardoso em 1611, para Ambaca, em terras pertencentes ao domínio do Ngola, a apenas um dia de distância da capital Cabaça. A decisão desagradou profundamente Ngola Mbandi, que reagiu contraatacando os portugueses. Uma segunda campanha militar contra Ngola Mbandi abalou definitivamente o poder político no Ndongo e os portugueses saquearam a capital Cabaça e aprisionaram muitas pessoas como escravas. Derrotado, Ngola Mbandi fugiu para as ilhas de Kindonga no rio Kwanza, deixando sua mãe e mulheres em poder dos portugueses. ${ }^{245}$

Mendes de Vasconcelos aproveitou o exílio do Ngola e quis instituir seu próprio candidato para o trono do Ndongo, Samba Antumba, batizado com o nome de Antônio Correia. Mas esta tentativa de golpe "não sortio efeito porque não foi obedecido assim por ser vivo Angola Ambande como porque este gentio não obedece senão os que são legitimamente filhos ou descendentes do rei”, como explicou posteriormente Fernão de Sousa. ${ }^{246}$

Para atacar o Ndongo, Luiz Mendes de Vasconcelos contou com o expressivo apoio dos bandos dos Jagas Caza Cangola, Donga e Cassanje, que receberam vinhos e armas (proibidos no trato em Angola) para lutar contra o Ngola. ${ }^{247}$ Os dois primeiros se rebelaram contra os portugueses logo após a invasão do Ndongo, devido à fome e aos maus tratos sofridos. ${ }^{248}$ Donga foi cruelmente derrotado, enquanto Caza Cangola foi obrigado a fugir do Ndongo.

Inicialmente contrário ao uso dos Jagas nas guerras, como visto, ao chegar a Angola Vasconcelos mudou de opinião e passou a contar com vários bandos desses

\footnotetext{
${ }^{244}$ História das relações entre a Angola portuguesa e o Ndongo. 1617-1624, $1^{\mathrm{a}}$ parte, escrita por volta do outono de 1624. Em Heintze, Fontes para a história de Angola. Vol.I. 1985. Doc. 23. p. 195.

245 . Relação de Manuel Severim de Faria. 1620. P. 61. Em nota do editor de Cadornega. Vol. I. p. E Brásio. Vol. VIII. P.136, de 23/2/1632.

246. História das relações entre a Angola portuguesa e o Ndongo. 1617- 1624. $1^{\mathrm{a}}$ parte. Em Heintze, Fontes para a hisória de Angola. vol.I.doc. 23. p.195.

${ }^{247}$ Cadornega. Vol.I. p.89 e Brásio.. Vol.VI.p.368

${ }^{248}$ Brásio. Vol. VI. P. 342. E Cadornega. Vol. I. p. 90.
} 
guerreiros mercenários. A aliança com os Jagas, principalmente com o bando liderado por Cassanje, foi fundamental para a invasão do Ndongo.

O enfraquecimento político do Ngola também fazia parte das pretensões de Cassanje, que desejava canalizar o tráfico de escravos para si, livrando-se da concorrência do Ngola. Após ocupar o Ndongo, Cassanje se recusou a sair das terras invadidas e se fixou com seu bando nas proximidades de Ambaca.

Segundo Vansina, os portugueses queriam que Cassanje se fixasse nas terras abandonadas pelo Ngola, provavelmente perto do rio Lucala, mas ele sabia que viver sob a efetiva jurisdição de um presídio era inoportuno. ${ }^{249}$ Ele se fixou longe o bastante para evitar a interferência dos capitães e perto o suficiente para estar apto a negociar com os portugueses, em Lucamba, onde continuou a viver de assaltos e aprisionamento de escravos. Foi para o leste, expulsando os Pende e ganhando novos guerreiros para seu exército até atingir a região de Cassanje.

A documentação disponível não permite que se tenha certeza sobre onde exatamente Cassanje se estabeleceu logo após a invasão do Ndongo. Ele teria ocupado uma região próxima a Ambaca e, posteriormente, na década de 1630, dirigiu-se a região conhecida como Baixa de Cassanje, onde fundou o estado de Cassanje, que se tornou um dos mais importantes centros comerciais da África Central até o século XIX.

Com parte do Ndongo ocupado, Cassanje se recusou a ser um mero fornecedor de escravos baratos para os portugueses e começou a roubar os pumbeiros que atravessavam a região que havia dominado e causou considerável prejuízo aos mercadores europeus. Com a fuga de Ngola Mbandi, Cassanje continuou atacando o Ndongo e apoderou-se de parte de suas terras. ${ }^{250}$ Sua presença passou a ser vista como inconveniente tanto para os portugueses, que tinham o tráfico de escravos ameaçado, como para o Ngola que perdera parte de seu território e ficou impedido de realizar as feiras. As campanhas contra mani Casanze da Nsaka obrigaram o deslocamento das tropas portuguesas para o interior de Luanda, permitindo que Cassanje consolidasse seu domínio da região próxima a Ambaca.

\footnotetext{
${ }^{249}$ Vansina.The fondation of the Kingdon of Kasanje.Journal of African History. IV (3),1963.

${ }^{250}$ História das relações entre a Angola portuguesa e o Ndongo. 1617- setembro de 1624. $2^{\mathrm{a}}$ parte. Em Heintze. Fontes para a hiória de Angola. Vol.I, 1985. P. 198-199. E nota do anotador de Cadornega. Vol. I. p. $152-153$.
} 
Durante os três anos de seu mandato, Luiz Mendes levou a cabo muitas guerras, que se estenderam desde o norte-nordeste, onde atacou o Ndembo Mbwila e outros sobas; Matamba, na porção leste; e mani Casanze da Nsaka, na região de Luanda. Luiz Mendes de Vasconcelos e seu filho, o tenente João Mendes, efetuaram violenta política de guerra contra muitos sobas, com decapitação de muitos poderosos que não aceitavam a dominação portuguesa. O cronista português Manuel Severim narrou o ataque ao Sova Gaita (Caita) comandado por João Mendes, chamando atenção para sua crueldade: "mandou degolar 94 poderosos com algum escândalo dos naturaes". ${ }^{251}$ As relações de Manuel Severim de Faria não constituem, no entanto, uma fonte segura pois seus escritos são notoriamente vinculados a suas intenções políticas, principalmente sua posição contrária ao perdão geral dados aos cristão novos em 1601. Neste sentido, o sacerdote tinha especial aversão à política desempenhada por Mendes de Vasconcelos, pertencente à família de judeus, e seus relatos são repletos de exageros e imprecisões. ${ }^{252}$

Para desestabilizar o reinado de Ngola Mbandi, Luiz Mendes de Vasconcelos também buscou apoio em famílias nobres tradicionais que queriam mudar o status quo e ascender ao poder político central, em uma tentativa de rearranjar e intervir nas forças políticas ali existentes. Foram avassalados os sobas da província do Are, detentores do título Are a Kiluanje, que descendiam dos antigos reis e desejavam assumir o título central Ngola. Cadornega falou de um poderoso, o soba Mobanga, "parente dos reis de Angola", que deu "porta e entrada por suas terras" ao governador para a invasão do Ndongo. ${ }^{253}$

As campanhas militares trouxeram consequências terríveis, tanto para o Ndongo como para Angola portuguesa. As feiras foram totalmente paralisadas e comércio legal de escravos foi suplantado pelo ilegal, em que os escravos provenientes dos ataques eram embarcados clandestinamente, com proveito para o próprio governador. Calculase que em torno de 50.000 escravos foram embarcados no mandato de Luiz Mendes de

\footnotetext{
${ }^{251}$ Relação de Manuel de Faria 1 de fevereiro de 1620. Emnota do editor em Cadornega. Op. Cit.V. I, p. 88. O editor de Cadornega comenta que na Biblioteca Nacional de Lisboa o mesmo documento fala da decapitação de 49 sobas. Em Brásio, vol. VI, p. 371 consta que 28 sobas foram decapitados.

${ }^{252}$ Manuel Severim de Faria escreveu em Lisboa dois livros em que se posicionou contrário aos judeus:

"Razões Para Não Se Admitirem Sinagogas em Portugal" e "Relação dos Castigos Que Tiveram os Reis de Portugal Que Favoreceram os Judeus".

${ }^{253}$ Cadornega. Vol.I. p. 130.
} 
Vasconcelos ${ }^{254}$, o que causou uma devastação demográfica no Ndongo, agravada pela seca, que já durava três anos, e pela fome generalizada.

A guerra contra o Ndongo teve como consequências a expansão formal do domínio português e a segmentação do reino, porém não alcançou a submissão efetiva de Ngola Mbandi. Na análise de Heintze, a perda da independência política do Ndongo foi um longo processo que durou 12 anos e cada uma de suas etapas corresponde aos mandatos dos diferentes governadores, que dirigiram a guerra e paz de formas diversas. $^{255}$

O editor de Cadornega, o cônego José Mathias Delgado, observou o mau comportamento do governador português: "Este governador, Luiz M. de Vasconcelos, foi um dos mais perniciosos governadores de Angola pelas gravíssimas consequências que resultaram das muitas extorsões feitas ao rei e da desmedida ambição tanto dele como de seu filho." 256

Luiz Mendes de Vasconcelos sofreu devassa em março de 1622 a fevereiro de 1623. A Coroa confiscou suas fazendas e ordenou seu desterro para o Brasil, mas ao chegar ali ele conseguiu escapar da prisão e embarcou secretamente para o reino, onde deu ao rei um memorial dos grandes serviços que fez em Angola e foi absolvido pela Justiça Real. A guerra movida contra o Ngola foi considerada injusta pela Coroa e pelos governadores subsequentes, que admitiram a ilegalidade da ação militar. ${ }^{257}$

\subsection{Dona Anna de Sousa: batismo e paz}

Luiz Mendes de Vasconcelos havia avassalado 190 sobas, dos quais 81 se comprometeram a pagar tributos. ${ }^{258}$ Mas quando seu sucessor, João Correia de Sousa, assumiu o governo, em outubro de 1621, encontrou a conquista em situação deplorável, com todos os sobas rebelados e nenhum tributário, as feiras estavam paralisadas e havia sérios problemas decorrentes da guerra: "Confesso as novas que acho de Angola estar

\footnotetext{
${ }^{254}$ Heintze. Angola nos séculos XVI e XVII. p. 296.

255 Idem. p. 281.

${ }^{256}$ Cadornega.Vol.1. p.98. nota do editor.

${ }^{257}$ Instrução secreta do rei a Fernão de Sousa. 19 de Março de 1624. Em Heintze, 1985. Doc.3. p. 137. E Regimento do governador de Angola. Em Heintze, 1985. Doc.4. p. 143

258 Relação de Manuel Severim de Faria. 1620. P. 61. Em nota do editor de Cadornega. Vol. I. p. 88-89.
} 
tudo revolto e baralhado mal me posso eu resolver no negocio dos soldados, de mais de trazer muy poucos, e elles de muy má vontade ficarem neste sitio." 259

A presença do Jaga Cassanje no centro do reino do Ndongo tornou-se o principal problema a ser resolvido pelo novo governador, que procurou Ngola Mbandi, para juntos vencerem o inimigo comum, que havia sido forjado nas guerras de Vasconcelos. Uma de suas primeiras ações foi procurar o Ngola, excusando-se das ações de seu antecessor, para que a paz fosse restabelecida e as feiras retomadas.

Para acertar a paz com os portugueses, a irmã mais velha do Ngola, Nzinga Mbandi, foi enviada a Luanda como sua embaixadora. As embaixadas eram frequentemente utilizadas nas negociações entre chefes na África Central e estavam presentes no cenário político no século XVII, tanto nas relações entre o Ngola e os sobas, como entre estes e os portugueses. Os embaixadores eram, tradicionalmente, pessoas de destaque e de confiança dos chefes africanos.

Cavazzi descreveu a embaixada com grandeza e magnitude. Nzinga foi de Cabaça a Luanda, acompanhada por numeroso séquito. Chegou toda ornamentada, carregada às costas, exibindo vários símbolos que representavam sua a alta dignidade: "a primeira vez que foi levada à audiência, apareceu carregada de gemas preciosas, bizarramente enfeitada de penas de várias cores, majestosa no porte e rodeada por grande grupo de donzelas, de escravas e de oficiais da sua corte." 260

Devemos refletir sobre o intenso uso de símbolos de poder nas sociedades africanas e o que eles significavam. A vestimenta com que Nzinga se apresentou aos governantes portugueses foi estrategicamente pensada para demonstrar sua importância política, refletida pela imponência de sua imagem.

$\mathrm{Na}$ audiência com o governador, uma cena foi especialmente recordada: o "episódio da cadeira". Nzinga, ao perceber que havia apenas uma cadeira para o governador e que ela deveria se sentar em um tapete no chão fez sinal a uma de suas donzelas, que prontamente ficou na posição de uma cadeira, "de gatinhas", em que Nzinga se sentou e permaneceu por toda a audiência. O episódio chocou os presentes, mas o que causou mais estranhamento na cultura europeia não foi o fato de sentar sobre

\footnotetext{
${ }^{259}$ Carta de João Correia de Souza a Manuel Cerveira Pereira. 4/10/1621. Em Cadornega, p.100 em nota. ${ }^{260}$ Cavazzi. Op. Cit. Vol.II.p.67
} 
a donzela. Em sua narrativa, Cavazzi fala que Nzinga foi carregada por mais de 100 léguas entre a capital Cabaça e Luanda, "como era costume no país". Em diversas passagens, os padres aparecem carregados nas viagens missionárias pelo interior. Os presentes ficaram atônitos mais pela atitude desafiadora de Nzinga, que não quis estar em posição inferior ao governador português e contrariou as expectativas demonstrando, por este gesto, sua forte personalidade e postura política que exigia respeito. Finda a reunião, Nzinga complementou o ato deixado a donzela na mesma posição e ao ser questionada, argumentou que não era digno se sentar duas vezes na mesma cadeira.

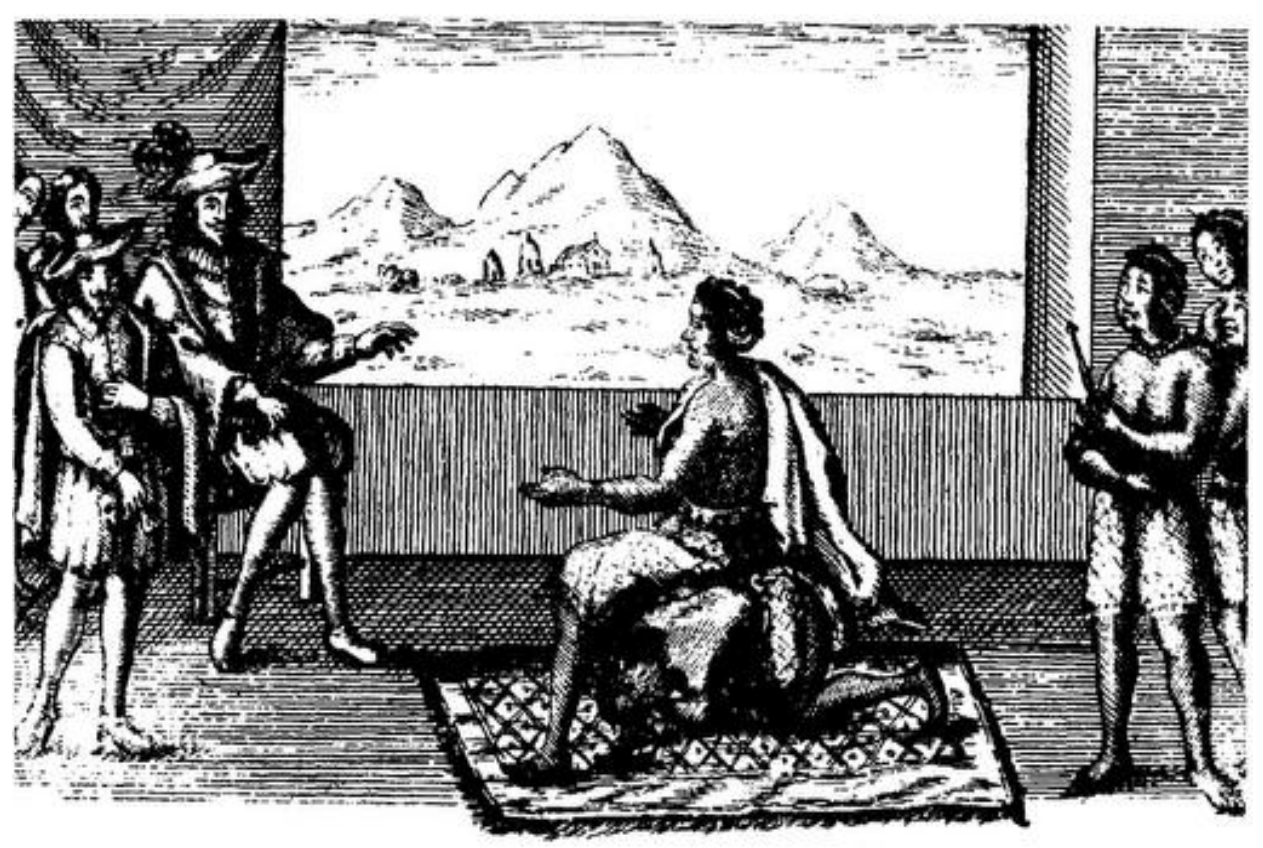

Em Cavazzi. Vol.II. p. 67

Cavazzi descreveu como os magistrados e conselheiros ficaram sem palavras diante da atuação de Nzinga: "Os presentes admiraram, todos pasmados, esta presteza em sair-se bem e vivacidade da sua inteligência, nunca esperado duma mulher tanta desenvoltura.",261

Segundo a descrição de Curvelier, os magistrados e conselheiros "ficaram pasmados quando ouviram uma mulher criada entre selvagens e animais bravios falar e

${ }^{261}$ Cavazzi.Op. Cit. p.67 
raciocinar com tamanha eloquência e propriedade de linguagem que parecia coisa sobrenatural". 262

Na audiência, Nzinga e o governador entraram em acordo para a restituição da paz e mútua amizade, mas quando foi dito que o Ndongo deveria reconhecer Portugal com tributo anual, Nzinga "respondeu que tal condição só se podia exigir duma nação submetida, mas não duma nação que espontaneamente oferecia uma mútua amizade." 263 Esta postura firme e resoluta convenceu os presentes de que o Ndongo deveria permanecer como estado livre, independente e aliado, sem contudo ser tributário do rei português, como era prática nas relações de vassalagem luso-africanas. Nzinga deixou claro que aceitava a paz e amizade com Portugal, mas como duas nações soberanas e livres, e de forma alguma aceitaria a submissão.

O governador João Correia de Sousa passou estimar Nzinga e "julga-la capaz de aprender a nossa santa religião". ${ }^{264}$ Ofereceu-lhe o batismo cristão, o que ela aceitou e recebeu o nome de Dona Anna de Sousa, tendo o governador como padrinho. Cadornega disse que sua madrinha foi uma "senhora autorizada", mulher do capitão mor de cavalos Luis Gomes Machado, chamada Jeronima Mendes e pelo nome da terra de Gombe a Coanza. ${ }^{265}$ Heintze inferiu que sua madrinha teria sido D. Ana da Silva, irmã de Francisco de Souza e esposa de Paio de Araújo de Azevedo, que mais tarde, em 1629 , teria acolhido em sua casa suas duas irmãs detidas.

\footnotetext{
${ }^{262}$ Curvelier. p. 53

${ }^{263}$ Cavazzi.Op. Cit. P. 68. Outra versão semelhante aparece em CadornegaVol. I. p. 153:"Respondeo-lhe João Correia, que para maior firmeza da alliança. Devia seu Irmão, reconhecer-se vassalo d'El Rey de Portugal e pagar um tributo annual: a isto, com prompta vivacidade, replicou a embaixatriz; que semelhante encargo, só poderia impor-se, a quem tivesse sido conquistado; e nunca a hum Principe Soberano, que procurava a amizade, de outro seu igual."

${ }^{264}$ Cavazzi. P.69

${ }^{265}$ Cadornega. Vol. I. p.115.
} 


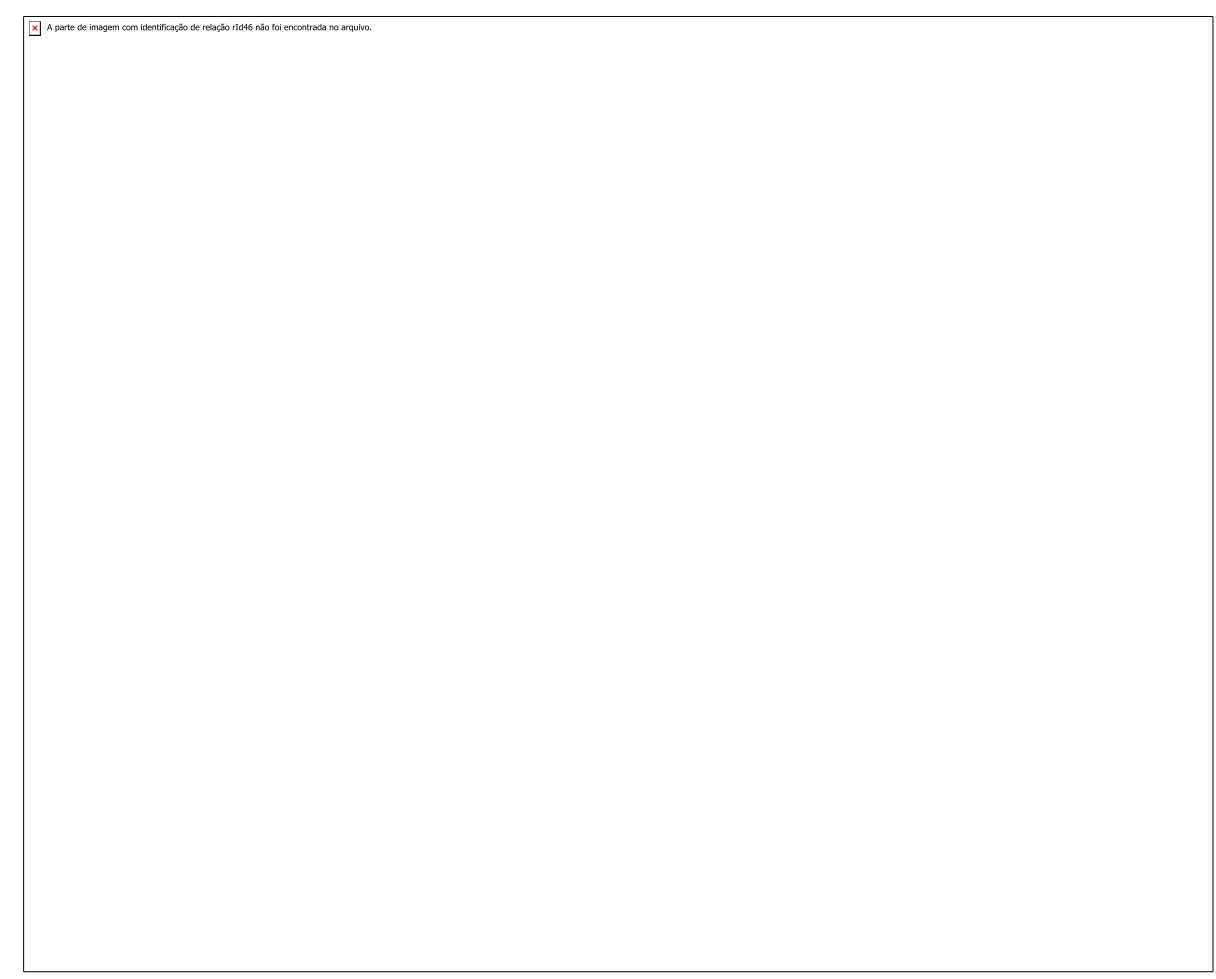

O Batismo de Nzinga. Fonte: Ezio Bassani, “Um Capuccino nell’Africa nera del seicento. I disegni de Manoscrito Araldi Del Padre Giovanni Antonio Cavazzi da Montecculo.” Quaderni Poro 4 (1987). Em Heywood-Thornton. Central africans, Antlantic creoles.. P. 125.

Antes de retornar à Cabaça, Nzinga, agora Dona Anna de Sousa, permaneceu em Luanda por algumas semanas, aproveitando para conhecer melhor a administração portuguesa.

A correspondência do governador Fernão de Sousa, temporalmente mais próximo ao evento, mostra outra versão desta embaixada, bem menos extraordinária. ${ }^{266}$ Conta que Nzinga e suas duas irmãs foram a Luanda na qualidade de reféns, como garantia para o acordo de paz. As três irmãs foram batizadas ao mesmo tempo em 1622, chamando-se Anna de Sousa, Maria e Gracia. ${ }^{267}$ Mocambo foi batizada inicialmente como Maria e mais tarde, adotou o nome de D. Bárbara de Araújo da Silva ${ }^{268}$, personagem importante na sucessão de Nzinga nas décadas de 1650-60.

Em Cavazzi, lê-se que as duas irmãs mais novas haviam sido capturadas no segundo confronto contra Luiz Mendes de Vasconcelos e seus regastes foram usados,

\footnotetext{
${ }^{266}$ História das relações entre a Angola portuguesa e o Ndongo. 1617-1624. $1^{\text {a }}$ parte. Em Heintze, 1985. P.196. e Heintze, Angola nos século XVI e XVII.p.305.

${ }^{267}$ Brásio. Vol. VIII, p. 137, Cadornega vol. I,p. 113,115.

${ }^{268}$ Legunzano em Cavazzi, II, 70 nota 148 e Cadornega I, 116.
} 
desde cedo, para convencer o Ngola a se sujeitar. Mas na versão do padre italiano, Nzinga aparece como embaixatriz especialmente selecionada por Ngola Mbandi, enquanto na versão de Fernão de Sousa, Nzinga aparece como prisioneira, sem tanto prestígio político. Fernão de Sousa escreveu que Nzinga foi designada como embaixatriz posteriormente, nos governos de Pero Sousa Coelho (1623) e do bispo Simão de Mascarenhas (1623-24) quando voltou a exigir o cumprimento do acordo firmado no ato do batismo.

O batismo de 1622 é um o momento histórico mais repetido e analisado da vida de Nzinga, apesar de ter sido apenas sua primeira atuação política pública. Após o acordo firmado com João Correia de Sousa, o prestígio de Nzinga cresceu na comunidade Mbundo e ela passou a ser vista como sábia diplomata e eminente liderança política, mas o episódio rendeu diferentes interpretações:

Glasgow interpretou que Nzinga teria ficado maravilhada com a cultura europeia que viu em Luanda e se admirou pela "disciplina e segurança das tropas lusas", "pela beleza e luxo das vestes empregadas pelo público", e pelo "esplendor das mobílias". ${ }^{269}$ Nesta análise, Nzinga teria concluído que os portugueses eram realmente um povo opulento e poderoso e que o povo Mbundo poderia alcançar tal poder se fosse aliado a Portugal. O autor escreveu que Nzinga foi convencida a se batizar, pois traçou uma associação entre tráfico, poder e fé e concluiu que o cristianismo lhe traria riquezas, poder para derrotar seus inimigos e lhe daria condições para se firmar como "Imperatriz de um Império Mbundo", noções anacrônicas para o universo africano do século XVII. No olhar de Glasgow, a ambiciosa Nzinga queria ter um "Estado todo-poderoso" e usaria o tráfico transatlântico e o cristianismo para isso.

Miller analisou que Nzinga, ao invés de salvar seu irmão, aproveitou sua visita à capital portuguesa para obter um triunfo pessoal ao aceitar o batismo e teria sido vista pelos portugueses como uma potencial condutora das esperanças evangelizadoras no reino do Ngola e do desenvolvimento de um comércio lucrativo. ${ }^{270} \mathrm{Na}$ análise de Miller, a aceitação de Nzinga do cristianismo garantiu o apoio português para sua ambição ao

\footnotetext{
${ }^{269}$ Glasgow. Nzinga.Resistência africana à investida do colonialismo português em Angola, 1582-1663. São Paulo Editora Perspectiva, 1982. p. 82.

${ }^{270}$ Miller. "Nzinga of Matamba in a new perspective" e Poder político e parentesco.
} 
poder Mbundo, uma vez que seus ganhos em diplomacia exterior teriam fortalecido a sua reivindicação à legitimidade. Miller interpretou a boa vontade de Nzinga para com os sacramentos cristãos como pouca lealdade ao seu próprio povo e cultura e afirmou que Nzinga teria usado o cristianismo como forma de se promover politicamente e ganhar aliados externos, já que não tinha legitimidade entre os Mbundo. Para ele, o batismo teria sido, desde cedo, uma estratégia de acomodação aos interesses portugueses no serviço de suas ambições políticas pessoais.

Heintze, que acredita e defende a versão de Fernão de Sousa, interpretou que as três irmãs, ao retornarem para junto de Ngola Mbandi, seriam intermediárias nas negociações de paz e evangelização no reino do Ndongo. Os portugueses esperavam que elas "pudessem ser úteis à estabilização das relações recém-estabelecidas." 271 Para ela, Nzinga agia em inteira consonância com Ngola Mbandi, que desejava a paz.

Marina de Mello e Sousa diz que Nzinga causou uma forte impressão no governador e nas demais autoridades portuguesas, comportando-se como habilidosa chefe de estado e que ela teria ficado impressionada com as grandes construções e embarcações que viu em Luanda, bem como o comportamento ritualizado do poder. ${ }^{272}$ Analisa que Nzinga entendeu o seu batismo como uma forma de construir relações de paz com os brancos, que, contudo, não foram alcançadas.

Luiz da Câmara Cascudo ficou fascinado pela história da rainha guerreira e lhe dedicou várias páginas. ${ }^{273} \mathrm{~A}$ repetição do episódio da cadeira, acima exposto, nos mostra como esta cena ficou retida na memória coletiva dos angolanos que vieram ao Brasil, sendo um dos fatos mais lembrados na longa história de Nzinga, tornando-se quase um mito.

Lenda e fato histórico se misturam. Mesmo que Nzinga tenha "estilizado" a embaixada de 1622 e exagerado seu papel político ao narrar os acontecimentos a Cavazzi, acreditamos que sua atuação foi destacada na assinatura do acordo de paz. O governo português viu em Dona Anna de Sousa a melhor alternativa para retomar o

\footnotetext{
${ }^{271}$ Heintze. Angola nos séculos XVI e XVII. P.305.

272 Sousa, Marina de Mello e. A rainha Jinga - África central, século XVII. Em ComCiência, Revista Eletrônica de Jornalismo Científico. 2008.

${ }^{273}$ Cascudo. Made in África. Civilização Brasileira, 1965.
} 
comércio e a paz com o Ndongo. Assim ela foi a primeira herdeira do título Ngola a aceitar o sacramento cristão.

Entendemos que a análise de Glasgow, de uma embaixadora fascinada pela cultura externa, não pode se sustentar já que Nzinga conhecia a experiência do cristianismo no Congo, iniciada 120 anos antes, e quando saiu de seu reino, provavelmente, sabia que o caminho para a paz com os portugueses passava pela aceitação de uma nova religião.

Cavazzi escreveu que Ngola Mbandi, ao preparar a embaixada à Luanda, aconselhou a irmã, e "acrescentou que, se os Portugueses mostrassem o desejo de atraíla ao cristianismo e de batizá-la, não se recusasse (...) que as aparências exteriores eram uma coisa e os sentimentos interiores outra coisa." 274

Nzinga não acreditava que o cristianismo era superior às crenças Mbundo, como supõe Glasgow. Devemos entender o cristianismo, nesta conjuntura da África Central e da expansão portuguesa, como condição sine qua non para a amizade mútua, como preliminar essencial para o diálogo com as autoridades europeias. O Cristianismo estava notoriamente envolvido com a política colonial no século XVII e Nzinga provavelmente sabia que teria que aceitar a cruz para conseguir a paz.

O Ndongo estava fragilizado depois da guerra iniciada em 1617: as feiras paralisadas, o Ngola refugiado, parte do território ocupado pelo Jaga Cassanje e seu bando de guerreiros fortemente armados. A expulsão de Cassanje foi uma das principais reivindicações no acordo de paz. Nzinga sabia que ia precisar da ajuda militar dos portugueses para tirá-lo de seu território; por outro lado, a ajuda militar portuguesa traria a obrigação do Ndongo com a Coroa lusa. ${ }^{275}$

O Ngola reivindicava também que todos os sobas ilegalmente aprisionados por Luiz Mendes de Vasconcelos deveriam ser restituídos à sua soberania, assim como os ijiku (traduzido como escravos, plural de kijico), justificando que não poderia governar sem seus súditos.

\footnotetext{
${ }^{274}$ Cavazzi. Op. Cit. p. 66.

${ }^{275}$ Heintze, Angola nos século XVI e XVII. P.288.
} 
Nzinga Mbandi, esta mulher inteligente e estrategista como foi descrita, provavelmente pesou todas essas condições ao ir a Luanda. Nzinga não aceitou o cristianismo porque ficou maravilhada pela cultura alheia, não foi o luxo dos palácios de Luanda que lhe convenceu a se batizar. Este pensamento de Glasgow revela continuidade do olhar eurocêntrico e despreza o entendimento dos chefes africanos em relação ao cristianismo.

Tampouco, Nzinga não foi desleal com seu povo para seguir ritos estrangeiros, como interpretou Miller. ${ }^{276}$ Refletimos como se deu esta aceitação do cristianismo: será que Nzinga deixou de acreditar nas crenças de seus ancestrais ao receber o batismo? Como ela entendeu o ritual cristão? O que significou a mudança de nome e o apadrinhamento do governador? Nzinga teria sentido Jesus Cristo tocar seu coração, como afirmou Cavazzi? ${ }^{277}$ Ou tudo não passou de uma fria decisão, sem fé, com o objetivo de conseguir um acordo de paz que fosse favorável ao Ndongo?

Podemos afirmar que Nzinga foi muito bem sucedida em sua primeira atuação como Ngambele (embaixadora), pois conseguiu acordar a retirada dos portugueses de Ambaca e a expulsão do Jaga Cassanje do Ndongo. Nzinga manteve o Ndongo como estado livre e independente, não aceitou o avassalmento e a submissão do Ngola, bem como não aceitou o pagamento de um tributo anual a Coroa portuguesa. Prometera aos portugueses abrir o reino para evangelização cristã e garantir a segurança nas feiras.

Entretanto, seu padrinho não cumpriu o acordo de paz, tampouco seus sucessores, não obstante Nzinga tenha presidido outras duas embaixadas aos novos governadores. ${ }^{278} \mathrm{~A}$ traição do acordo pelos portugueses agravou a crise no Ndongo e frustrou as expectativas de paz do Ngola, que morreu sem nunca ser batizado.

Entendemos o batismo de Nzinga Mbandi como uma estratégia política para obter a paz no Ndongo, em um momento que o reino estava altamente fragilizado devido às guerras movidas por Luiz Mendes de Vasconcelos. A paz viria acompanhada

\footnotetext{
${ }^{276}$ Miller. "Nzinga of Matamba..."

${ }^{277}$ Cavazzi. Op. Cit. p. 69.

${ }^{278}$ Pedro de Souza Coelho, que governou brevemente em 1623 e o Bispo Simão de Mascarenhas, que governou em 1623-1624. Cardonega mencionou as tentativas de Nzinga em fazer valer o acordo. P.161. Fernão de Souza explicitou também estas tentativas. Carta de Fernão de Sousa ao governo. 15/8/1624. Em Heintze. Fontes para a história de Angola. 1988. Vol.II p.85. doc. 36
} 
da prosperidade gerada pelo comércio com os portugueses e da ajuda militar contra os inimigos.

Apesar do batismo de Nzinga, o Ndongo não se tornou um reino cristão. Ngola Mbandi se recusou a ser batizado por Dionísio de Faria, o sacerdote negro natural de Matamba, enviado para lhe consagrar o batismo. O Ngola achou um absurdo terem lhe enviado um "filho de uma escrava sua"279, enquanto sua irmã recebera o sacramento com toda a pompa e honras do governador. Ngola Mbandi permaneceu exilado em Kindonga, deixando o vácuo no poder central do Ndongo, aguardando o cumprimento do acordo, o que nunca ocorreu.

\subsection{Nzinga Mbandi, senhora de Angola}

O governador Fernão de Sousa (20/6/1624 a 4/9/1630) foi mandado a Angola para salvar a colônia da ruína causada pela ganância dos governadores passados. Os lucros da colonização deveriam ser revertidos exclusivamente para a Coroa, sendo preferencialmente obtidos pelo comércio e não pela guerra. O rei mandava que se desenvolvesse a mineração de cobre em Benguela e estimulasse a agricultura através da concessão de terras. ${ }^{280}$

O rei lhe passou instruções para que fizesse todo o possível para ter paz e amizade com Ngola Mbandi e tê-lo sob obediência, assim como deveria agir com todos os sobas, "por meios brandos e sem rigor." Reconhecia que governadores passados moveram guerras injustas contra sobados em benefício próprio e decretou que os sobas que aceitassem a evangelização em seu território não deveriam ser obrigados a pagarem tributos. O rei sistematizou melhor a taxação dos sobas, e para que não houvesse excessos, determinou que os baculamentos deveriam ser pagos voluntariamente pelos sobas que recebessem ajuda militar contra seus inimigos, caracterizando assim a relação de vassalagem. ${ }^{281}$ Segundo seus cálculos, em 1624, havia 81 sobas que pagavam voluntariamente cerca de 320 escravos, o que rendia 22 mil réis a Coroa, e havia outros 109 sobas que poderiam vir a ser tributários se a guerra não os incomodasse. Assim a

\footnotetext{
${ }^{279}$ Livros de Fernão de Souza, Tomo I, fl. 326 ao fundo, e tomo III, fl. 30. Em nota do anotador de Cadornega. Vol. I. p. 153

${ }^{280}$ Instrução secreta do rei ao governador. 19/03/1624. Em Heintze, 1985. doc. 03. p.136-137.

${ }^{281}$ Regimento do governador de Angola. 20/03/1624. Em Heintze, 1985. doc. 04. p.145.
} 
Coroa estimava que o comércio pacífico e a cobrança "sem extorsões e com suavidade" seriam mais lucrativos que a guerra.

Mas antes que Fernão de Sousa pudesse realizar as ordens régias, Ngola Mbandi morreu na ilha de Kindonga. A data de sua morte é incerta. Curvelier afirmou que Ngola Mbandi morreu no final de $1623^{282}$. Heintze situou sua morte na primavera de 1624, mas utilizou a divisão de estações do ano pelo ponto de vista do hemisfério norte. $^{283}$ Sabemos que ele morreu entre março, quando o rei recomendou a Fernão de Sousa ter paz com o Ngola, e junho de 1624, quando o governador chegou a Angola e encontrou a crise de sucessão.

Segundo Cadornega, Ngola Mbandi teria adoecido e morrido de causas naturais. ${ }^{284}$ Cavazzi descreveu Ngola Mbandi como um soberano déspota, que assumiu o poder violentamente, governou com a espada e assassinou os seus possíveis sucessores, dentre eles o filho de Nzinga, que passou a odiá-lo. Na visão eurocêntrica de Cavazzi, foi Ngola Mbandi que invadiu as conquistas portuguesas, sendo derrotado e obrigado a se refugiar na ilha de Danji. Na sua narrativa, Ngola Mbandi foi sitiado pelos portugueses e abandonado pelos seus, "de maneira que não teve outro remédio senão morrer de veneno que, conforme o boato, lhe foi entregue pela própria Jinga”, que quis vingar a morte de seu filho. A narrativa de Cavazzi apresenta a visão dos fatos segundo a concepção portuguesa, nem menciona o não cumprimento do acordo de 1622 e tem vários erros cronológicos graves, por exemplo, diz que Ngola Mbandi morreu em 1627. ${ }^{285}$ Esses boatos de que fala Cavazzi circulavam nas décadas de 1650-1660, muitos anos depois das intensas guerras de perseguição contra Nzinga, que afetaram negativamente sua imagem diante dos portugueses.

As cartas de Fernão de Sousa revelam informações importantes sobre esta passagem, e estão bem mais próximas temporalmente do evento. Em 15 de Agosto de 1624, o governador escreveu ao governo noticiando a morte do soberano:

"El Rey d'Angola he falecido de hus pôs de peçonha que tomou de paixão por lhe não cumprir o governador João Correa de Souza a promessa que lhe tinha feito de mudar o presídio da Embaça pera a Luynha conforme ao assento que se tinha tomado sobre isso

\footnotetext{
${ }^{282}$ Curvelier. Biographie coloniale belge. Vol.II. p. 741. Em Cavazzi. P.70. Em nota

${ }^{283}$ Heintze. Angola nos séculos XVI e XII. P.182.

${ }^{284}$ Cadornega. Vol.I.p.53

${ }^{285}$ Cavazzi. Op. Cit. p. 64- 70.
} 
per autos que ficao em meu poder. Deixou nomeada no trono Dona Anna de Souza sua irmã que esta baptisada, mas ella se não nomea senão senhora d'Angola. Tenho carta sua em que me diz que mudando o presídio se sahira logo das ilhas donde esta (ilha de Quindonga) e se passará para a terra firme e que fará as feiras na Quiçala onde se costumavao fazer, e que mandará aos seus que venhão a ellas,e que tragão peças por o ter assy assentado com os seus macotas, que são os do conselho, e que semeará as terras, e pedirá padres da Companhia para baptizarem os que quizerem fazer christãos, e o seu tendala, que he a pessoa principal se quer logo baptizar e pede ao Bispo lhe mande levantar igrejas, e que se lhe mande hua pessoa de respeito pêra tratar distas coisas. Pólas razões que se apontão no auto que fez João Correa, e no que fez Pero di Souza, retificou o Bispo servindo de governador, que todos tenho em meu poder, me parece que será de grandi serviço de Deos, e di Vossa Magestade mudarse o presídio da Embaça pera a Luynha por não aver nisso perigo por estar o Reyno muito pobre, e falto de gente, e quando parecer tornar a situar o presídio onde esta podesse fazer, e perdendo esta boa ocasião, que Dona Anna offerece do Christianismo,e abrir dos caminhos e principiar feiras não se tornara a ter tão boa, o que importa muito para a Fazenda di Vossa Magestade e bem comum disti Reyno em que há grande falta de peças."286

Em outro documento, escrito ainda em 1624, Fernão de Sousa escreveu:

"E vendo ElRei Angolla estas dilaçoens que eram enganos, e de paixão morreo e dizem que de peçonha que ele mesmo tomou de desesperado. Morto ele ficou em seu lugar Dona Ana de Sousa Ginga Ambande que já era cristã, e avizou o Bispo de sua morte pedindo cumprimento dos autos a que o Bispo não deu cumprimento logo."287

Os documentos evidenciam o suicídio de Ngola Mbadi por desgosto. O não cumprimento do acordo de 1622 por parte dos governadores portugueses aparece como causa direta da morte. Nzinga aparece como soberana legitimamente nomeada, cristã, disposta a regularizar o comércio no Ndongo e negociar com os governadores portugueses, assim, é vista como uma aliada, como uma ótima oportunidade para se firmar a paz no Ndongo e retomar as feiras. Chamamos atenção para a abrupta mudança de opinião de Fernão de Sousa em relação a Nzinga Mbandi ao longo de seu governo, que será analisada a seguir.

Seguindo as interpretações de Miller, em que a morte simbolizaria a extinção do título e não apenas da pessoa ${ }^{288}$, a morte de Ngola Mbandi pode ser entendida como um suicídio político,uma vez que ele estava derrotado e sem o apoio dos seus, só lhe caberia morrer, deixando vago o cargo de Ngola.

\footnotetext{
${ }^{286}$ Carta de Fernão de Sousa ao governo. 15/8/1624. Em Heintze. Fontes para a história de Angola. 1988. Vol.II p.85. doc. 36

${ }^{287}$ História das relações entre a Angola portuguesa e o Ndongo- 1617 a $1624.1^{\mathrm{a}}$ parte. Em Heintze. Fontes para a história de Angola.1985. Vol.I. doc.23. p.196. Ver também $2^{\mathrm{a}}$ parte da História das relações... Heintze, 1985. doc. 24 p. 199.

${ }^{288}$ Miller. Poder político e parentesco. P.169. refere-se a morte de Kinguri.
} 
Ngola Mbandi deixou seu único filho sob a guarda do Jaga Caza. Cadornega registrou que o soberano deixou seu herdeiro com o Jaga Caza, por não se fiar em Nzinga. ${ }^{289}$ Cavazzi escreveu que Nzinga Mbandi mandou afogar seu sobrinho no Kwanza após fingir amor a Caza. ${ }^{290}$ Caza certamente era um grande guerreiro que seria capaz de educar o futuro Ngola nas artes da guerra e protege-lo. Mas protege-lo de quem? Quem mais concorria ao trono do Ndongo e ameaçava a vida do futuro herdeiro? Os documentos de Fernão de Sousa deixam transparecer que Ngola Mbandi desejava proteger o filho dos portugueses, que seriam já neste momento a maior ameaça à soberania do Ndongo: "O pouco que possuhya deixou encomendado a Dona Ana de Sousa sua irmã e em poder do jagua Caza hum só filho por lhe parecer que estava com ele mais seguro de nós." 291

Todas as fontes afirmam que a guarda do sobrinho - e das insígnias de poder foram delegadas ao Jaga Caza, mas pouco se refletiu sobre esta tutela. Seria este o mesmo Jaga Caza Cangola que agiu ao lado de Vasoncelos para invadir o Ndongo e depois se rebelou ? $^{292} \mathrm{O}$ que significou a escolha de um Jaga para proteger o herdeiro do trono do Ndongo? Sinaliza que os Jagas já tinha um grande prestígio na corte do Ndongo, e tinham uma relação próxima com o Ngola, a tal ponto que lhes foi confiada a sucessão do reino. Redinha mencionou que "alguns antigos Ngolas usaram o título de Jaga, embra não esteja esclarecido em que medida o título correspondia a alguma entidade étnica ou grupal, ou constituía designação honorífica". ${ }^{293}$

Fernão de Sousa registrou que Nzinga, "através de dádivas que deu ao Jaga Caza”, recebeu o sobrinho e o matou para assumir o poder. Ele enxergou descuido do Bispo Simão de Mascarenhas, seu antecessor, porque se este houvesse pedido o herdeiro ao Jaga "pudera metelo no Reyno gem nome de Vossa Magestade com que

\footnotetext{
${ }^{289}$ Cadornega. Vol.I.p.53

${ }^{290}$ Cavazzi. Vol.II.p.106-107.

${ }^{291}$ História das relações entre a Angola portuguesa e o Ndongo- 1617 a setembro de $1625.2^{\mathrm{a}}$ parte. Em Heintze. Fontes para a história de Angola.1985. Vol.I.doc.24. p. 199.

${ }^{292}$ Heintze afirma que sim, seria D. João Casa Cangola. Em 1985. P.199. nota 22.

${ }^{293}$ Redinha, José. Boletim Cultural da Câmara Municipal de Luanda, No 23, Abril - Junho, 1969, páginas 25-31. Disponível em: http://introestudohistangola.blogspot.com.br/2006/05/31-donde-vem-o-nomeangola.html
} 
ficava tudo seguro"294, já mostrando seu desejo de intervir na escolha do governante do Ndongo.

Em dezembro de 1624, Fernão de Sousa escreveu ao governo dando conta do terrível cenário da conquista: os holandeses ameaçavam o litoral e seriam ajudados pelo rei do Congo, que preparava um ataque por terra; faltavam soldados e alimentos para as tropas e presídios; a indisciplina nos pelotões era tamanha que todos queriam ser capitães. Completa a carta noticiando:

"Dona Anna senhora de Angola me aperta muito que lhe cumpra a palavra que lhe deu o governador João Correa de Sousa, e que lhe mude o presídio da Embaça, e que logo se passará para terra firme, e mandará buscar padres da Companhia, e levantará igreja, e fará feiras largandolhe Vossa Magestade os quizicos e sovas que com a guerra que diz se lhe fez injusta lhe tomarão do que tenho dado conta, e apontado as razões que pera isso há, fico esperando hordem pera seguir a que for em mais serviço de Vossa Magestade. ${ }^{295 ", ~(g r i f o ~ n o s s o) ~}$

Fernão de Sousa mostrava-se favorável à retirada de Ambaca, que a esta altura não era um entreposto importante, difícil de guarnecer, "muito sujeito a cobiça dos brancos". ${ }^{296}$ João Correia de Souza já havia aprovado junto à Câmara a mudança de Ambaca para o Luinha, em posto que facilitasse a defesa do território, pensando em promover a paz com o Ngola e retomar as feiras no Ndongo. Apesar de aprovada e enviada ao rei, a ação não foi realizada pelos sucessores de João Correia, evidenciando a ruptura da política colonial a cada mudança de governo. Quando chegou a Angola, Fernão de Sousa prometeu a Nzinga retirar-se dali, aguardando somente a ordem de Felipe III para isto. Justificou sua demora por ainda não ter chegado no reino João Correia de Sousa para melhor apreciação dos fatos pelo rei. ${ }^{297}$ Bento Banha Cardoso também defendia a saída de Ambaca, pois em sua opinião o presídio estava condenado a extinguir-se devido a grande distancia que o separava de Luanda e estava muito vulnerável a algum levantamento ${ }^{298}$. No final de 1624, a câmara de Luanda decidiu que a retirada de Ambaca só ocorreria após ordem expressa do rei e que os ijiku injustamente tomados por Luiz Mendes de Vasconcelos só seriam devolvidos após

\footnotetext{
${ }^{294}$ História das relações entre a Angola portuguesa e o Ndongo- 1617 a setembro de 1625. $2^{\mathrm{a}}$ parte. Em Heintze. Fontes para a história de Angola.1985. Vol.I.doc.24. p. 199.

${ }^{295}$ Idem. p. 199.

${ }^{296}$ Idem. p. 198.

${ }^{297}$ Extenso relatório do governador a seus filhos. 1630. Em Heintze, 1985. Doc.30.p. 227.

${ }^{298}$ Arquivo Histórico Ultramarino (AHU). E-83. Citado por Parreira. Economia e sociedade na época da rainha Jinga. P.191.
} 
Nzinga se avassalar. ${ }^{299}$ Ao invés de se retirar de Ambaca, o governo se fortaleceu na região e inaugurou ali uma feira de escravos ainda em $1624 .{ }^{300}$ A partir deste momento, Ambaca ganhou cada vez mais importância no avanço da colonização portuguesa e tornou-se pólo de irradiação da "cultura atlântica criola". 301

\subsection{As fugas para o kilombo de Nzinga}

No conturbado cenário politico do Ndongo, dilacerado pelas sucessivas guerras, muitas levas de escravos fugiam de seus senhores e buscavam proteção junto a Nzinga. Em setembro de 1625, Fernão de Sousa registrou:

"Estando nesta concórdia com Dona Ana começarão a fogir escravos nossos para ella, e continuando em os persuadir que fossem livres e em os recolher, e emparar se começou a sentir a falta deles com grandes queixas por toda a conquista por serem muitos e todos de guerra com que ella se melhora, e este Reyno se enfraquece porque se não pode fazem sem gente preta que faz a sombra dos arcabuzes." ${ }^{\text {302 }}$

A grande fuga de escravos para o junto de Nzinga passou a preocupar o governador, sobretudo porque a maioria eram kimbares- escravos ou forros entregues pelos sobas para servirem como soldados a favor dos portugueses de acordo com os tratados de vassalagem e atuavam principalmente na defesa dos presídios. Uma vez que os kimbares eram militarmente treinados, a fuga para as fileiras de Nzinga significou grande fortalecimento de seu exército e, ao mesmo tempo, representou a perda do contingente militar português e seu consequente enfraquecimento. Tal movimentação causou indignação e revolta em colonos europeus e sobas africanos que perderam seus domínios e passaram a pressionar o governo para que a questão fosse resolvida.

Heintze analisou a grande mobilidade de escravos em Angola no século XVII, considerado como um "século de fugitivos". ${ }^{303}$ A autora pensa a fuga de escravos como a forma mais significativa e eficaz de resistência, que levaria à liberdade real dos indivíduos aprisionados. Apesar das enormes dificuldades que os caminhos apresentavam para estas fugas e o perigo de ser delatado e novamente escravizado,

\footnotetext{
${ }^{299}$ Brasio. Vol. VII. P. 249 e seguintes.

${ }^{300}$ Heintze. Angola nos séculos XVI e XVII. P. 327.

${ }^{301}$ Heywood- Thornton. Central africans, atlantic creoles, and the fondation of the Americas. Mapas.

${ }^{302}$ História das relações entre a Angola portuguesa e o Ndongo- 1617 a setembro de 1625. 2a parte. Em Heintze. Fontes para a história de Angola.1985. Vol.I.doc.24. p. 199.

${ }^{303}$ Heintze. Angola nos séculos XVI e XVII. Capítulo 12: Asilo ameaçado: oportunidades e consequências da fuga de escravos em Angola no século XVII. Pp.507-538.
} 
houve diversos pontos de asilo aos escravos: o sertão de Luanda, na Nsaka de Casanze; a Quissama, para onde fugiam escravos das fortalezas de Muxima, Massangano e Cambambe; os Ndembu e o reino do Congo; Ndongo e Matamba, onde Nzinga Mbandi acolhia "aldeias inteiras" de escravos fugitivos. O reino de Cassanje também passou a seu um pólo de atração de escravos fugidos a partir da década de 1630.

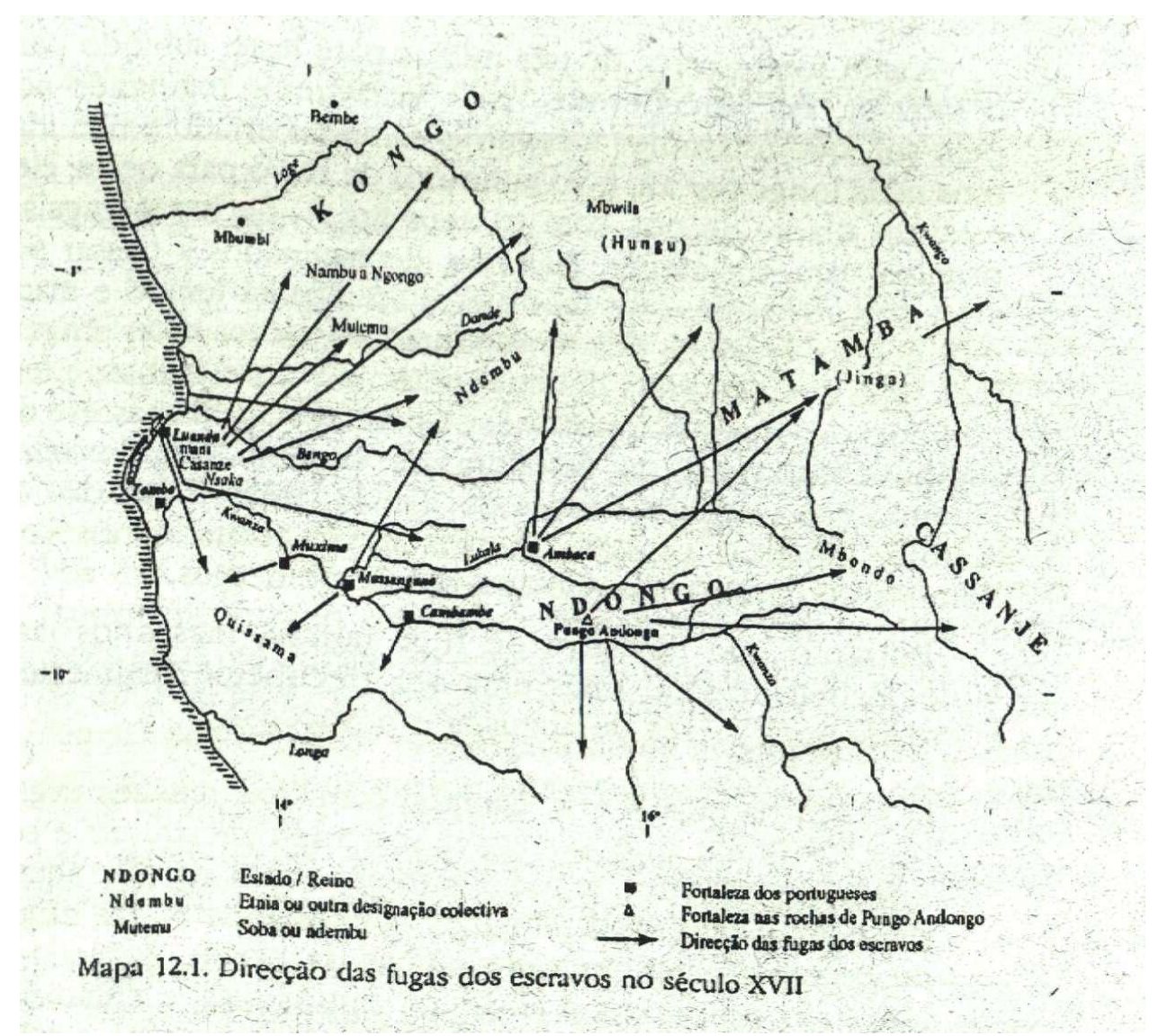

Em Heintze. Angola nos séculos XVI e XVII. P. 516.

Segundo Heintze, os escravos acolhidos por Nzinga procediam, em sua maioria, da região onde receberam asilo, ou seja, eram provenientes do próprio Ndongo, o que os diferenciava dos demais fugitivos do século XVII. ${ }^{304}$ Tinham vivido na região como camponeses livres ou como escravos do rei do Ndongo, e grande parte havia sido aprisionada injustamente nas guerras movidas por Vasconcelos e acabaram na escravatura portuguesa. Fernão de Sousa chegou a levantar a dúvida se eles não teriam

${ }^{304}$ Heintze. Angola nos séculos XVI e XVII. P. 518. 
readquirido, pela fuga para junto da comunidade de origem, o estatuto de pessoas livres e se assim fosse Nzinga não teria mais a obrigação de devolvê-los. ${ }^{305}$

Nzinga negava haver escravos fugidos junto a ela ${ }^{306}$, talvez por acreditar que a escravização acontecera de forma ilegal. Estes fugitivos contribuíram de modo decisivo para garantir a sobrevivência física e política de Nzinga, tornando-se soldados leais a ela. O governo português sabia do perigo que esta mobilidade representava, tanto que Fernão de Sousa chegou a propor perdão a todos os escravos fugidos que estivessem dispostos a regressar à "guerra preta" e prometeu libertar todos os escravos que Nzinga restituísse. ${ }^{307}$ Fernão de Sousa escreveu ao governo lamentando a fuga dos escravos:

“ Dona Ana se resolveo em não entregar os escravos, e posto que toda a conquista se queixa da sua fogida por respeito da perda, porque são todos de guerra e não heide dar pólos recuperar sem expressa ordem de V.M." ${ }^{\text {308 }}$

Nzinga chegou a propor a Fernão de Sousa a entrega dos escravos fugitivos desde que o governador lhe enviasse padres da Companhia de Jesus. Os padres Jeronimo Vogado e Francisco Pacconio foram até Ambaca com o intento de atender a reinvindicação, mas foram orientados a não passarem adiante até que Nzinga entregasse os escravos, pois se temia que Nzinga usasse os padres para evitar uma guerra. Os jesuítas não passaram para ela e os escravos fugitivos não foram devolvidos.

As grandes levas de escravos fugidos que se agruparam em torno de Nzinga trouxe consequências econômicas, políticas, militares e socioculturais relevantes para a região. As antigas linhagens foram enfraquecidas, novos valores surgiram e as elites foram reconfiguradas. Heintze sugere que isto tenha favorecido "um alargamento dos horizontes e uma internacionalização da vida", uma vez que os fugitivos traziam informações variadas sobre conhecimentos agrícolas ou rituais. ${ }^{309}$ Toda esta movimentação levou à formação de novas identidades étnicas, principalmente no

\footnotetext{
${ }^{305}$ Carta de Fernão de Sousa ao governo. 22 de junho de 1625. Em Brásio. Vol. VII. Pp. 362-363.

${ }^{306}$ Brásio. Vol. VII. P. 361.22 de agosto de 1625.

${ }^{307}$ Carta de Fernão de Sousa. Em Heintze, Fontes para a história de Angola. Vol. I. 1985. P. 205.

${ }^{308}$ Carta de Fernão de Sousa ao governo. 6 de setembro de 1625. Em Heintze, Fontes para a história de Angola.Vol .II. 1988.p. 142. doc. 60

${ }^{309}$ Heintze. Angola nos séculos XVI e XVII. P.535.
} 
nordeste, onde uma nova "etnia" chamada Jinga ganhou visibilidade a partir do final do século XVII, processo chamado etnogénese.

Nzinga Mbandi começou a aparecer como uma alternativa à escravidão, uma esperança de liberdade para aquele povo que era visto pelos portugueses ou como mercadoria ou como soldados para escravização de outros semelhantes. A fuga para junto de Nzinga significou para aqueles cativos a possibilidade de recuperar a liberdade, representou uma posição contrária a política europeia desempenhada em Angola, que tinha seu principal objetivo a escravização da população. Foram estes fugitivos que sustentaram politica e militarmente Nzinga durante todo o período que ela esteve contrária aos portugueses.

Nzinga se recusou a cooperar com os portugueses enquanto não se cumprisse as cláusulas do acordo de 1622. Recusava-se a aceitar as exigências que buscavam submete-la a vassalagem, entravando assim os planos portugueses de promoverem as feiras pelo Ndongo. Muitos sobas já avassalados passaram a apoiar Nzinga e romperam os laços com os portugueses, como ocorreu em Musseque ${ }^{310}$. Nzinga soube se aproveitar de outros conflitos na África Central e canalizar a seu proveito a inimizade de alguns portugueses, como ocorreu com o soba Ambuíla (Mbwila), um soba Ndembo que se recusava a pagar tributos aos Portugueses. A insubmissão justificou a guerra contra o Ndembo Ambuíla em 1625, considerado território estratégico devido à existência de minas de cobre.

A situação no Ndongo estava cada vez mais critica: as feiras paralisadas, o Jaga Cassanje continuava no território impedindo o comércio, assaltando as caravanas e também acolhendo levas de fugitivos.

Fernão de Sousa registrou as diversas opiniões que havia na época sobre como proceder, revelando as prematuras intenções de intervir diretamente na política do Ndongo:

"são vários os pareceres porque huns dizem que se faça guerra a Dona Ana antes acabe de recolher todos os escravos, porque depois de fogidos não teremos com que lha fazer, e que se acabe o nome de Rey de Angola porque enquanto o ouver ade ser inimigo, e que se faça Dongo província como a Ilamba. Outros são de parecer que a guerra se a

${ }^{310}$ Brásio. Vol.VIII. p. 360 
primeiro de fazer ao jaga Caçanze, e desalojado do sitio em que está se concertará e comporá o Reyno pondo nele rey que o governe, que abra feiras, e comercio."311

Heintze enxerga uma "instrumentalização" da acusação do recolhimento de escravos para junto de Nzinga para justificar a decisão de fazer guerra contra ela, no verão de 1625. Argumenta que estas queixas, que levaram à decisão formal de guerra, aumentaram nitidamente após a chegada de reforços vindos de Portugal, em que Bento Banha Cardoso chegou com 200 soldados e material de guerra. Já Miller entende que Nzinga usou os escravos fugidos como uma forma de pressionar o governo português para que o acordo de 1622 fosse cumprido. ${ }^{312}$

Só a partir da recusa de Nzinga em cooperar com os anseios comerciais e políticos do governo português, que Fernão de Sousa criou a tese de sua ilegitimidade e passou a considerá-la usurpadora, alegando que ela teria assassinado seu irmão Ngola Mbandi. A partir daí, Nzinga passou a ser vista como a principal inimiga dos portugueses em Angola e o objetivo primordial do governador passou a ser capturá-la e expulsa-la do Ndongo.

Os três documentos reunidos por Heintze sob o título "História das relações entre a Angola portuguesa e o Ndongo",313 evidenciam a mudança da atitude de Fernão de Sousa ao longo de seu mandato e mostra como o governador tentou manipular os fatos para macular a imagem de Nzinga Mbandi. Na última parte desta "História", escrita em Agosto de 1631, após entregar o governo, Fernão de Sousa fez uma síntese dos principais fatos que justificavam o fracasso do comércio de escravos em Angola. Percebe-se nitidamente a alteração da versão antes contada:

\footnotetext{
"Quando tomey posse do governo de Angolla, era falecido Angola Ambande Rey e senhor natural daquele Reyno, de peçonha, que lhe deu Ginga Ambande, sua irmã pollo não poder desviar da pax e amizade que o governador João Correia de Sousa the ofereçeo (...)e pollo grande ódio que tem aos portugueses e ha nossa Santa Fee, o matou, e a hum filho seu único, e legitimo sucessor e o abrio, e lhe comeo o coração, e o corpo mandou lançar no rio Coanza, pera com essa impiedade se fazer temida, e senhora obedecida dos sovas. ${ }^{314,}$
}

\footnotetext{
${ }^{311}$ História das relações entre a Angola portuguesa e o Ndongo- 1617 a setembro de 1625 . $2^{\mathrm{a}}$ parte. Em Heintze. Fontes para a história de Angola.1985. Vol.I. doc.24. p. 200.

${ }^{312}$ Miller, Nzinga of Matamba in a new perspective.P.208.

${ }^{313}$ Heintze, 1985 documentos: 23, 24 e 25. Pp.195- 203.

${ }^{314}$ História das relações entre a Angola portuguesa e o Ndongo. 1624-1631 (6/08/1631). 3 a parte. Em Heintze, 1985. Doc.25.P.201
} 
Fernão de Sousa passou a divulgar esta imagem de Nzinga Mbandi como cruel fratricida, como déspota bárbara e sanguinária, ilegítima e usurpadora do poder. Claro que esta tese contribuía para sustentar os interesses políticos do governo português e justificar tantos anos de perseguição e o pesado investimento na guerra que se fizera para combater Nzinga.

\subsection{O golpe político de Fernão de Sousa}

Fernão de Sousa não se atrevia a fazer guerra contra Nzinga sem expressa autorização do rei, já todas as guerras que não servissem para a defesa de Luanda e dos presídios estavam expressamente proibidas. ${ }^{315}$ Como Nzinga não havia atacado os portugueses, a guerra contra ela seria uma preventiva- e não defensiva- justificada pelo acolhimento dos escravos fugidos. Em 1625, a Câmara discutia a legitimidade da guerra enquanto Fernão de Sousa defendia a expulsão do Jaga Cassanje e criava a tese da ilegitimidade de Nzinga, "que tiranicamente esta intruza no Reyno". 316 O governador pedia a prisão de Nzinga e de suas irmãs e defendia a nomeação de "rei natural a quem per direito pertencer", desde que fosse avassalado e se comprometesse em pagar 100 peças anuais. Como o novo rei precisaria ter domínios, Fernão de Sousa defendia a saída de Ambaca e a devolução dos sobas e ijikus tomados na guerra de Vasconcelos.

Por volta de janeiro de 1626, o governador escreveu ao capitão mor Bento Banha Cardoso para que se procedesse com o plano de instaurar no poder Are a Kiluanje, mandando convocar em Ambaca os sobas e macotas que tradicionalmente elegem o rei, principalmente o soba Mobanga que ajudaria nas negociações ${ }^{317}$. Repare que se quis criar um ar de legitimidade para o processo, mas antes mesmo que qualquer consulta aos tradicionais eleitores ocorresse, o governador já deixou nomeado Are a Kiluanje:

\footnotetext{
${ }^{315}$ Regimento do governador de Angola. Em Heintze, 1985. Doc. 04. P. 137. E Brásio. Vol. VII.p 361. ${ }^{316}$ História das relações entre a Angola portuguesa e o Ndongo- 1617 a setembro de 1625. $2^{\mathrm{a}}$ parte. Em Heintze. 1985. doc.24. p. 200.

${ }^{317}$ Regimento do governador de Angola. Em Heintze, 1985. Doc. 04. P. 137. E Brásio. Vol. VII.p 361.
} 
"e convindo que a sucessão pertence a Aire Aquilonge o nomearão e o levantarão por rei legitimo do Reyno de Dongo porque demais de lhe pertencer he muy conveniente sello por ser vassalo d'ElRey nosso senhor amigo e confederado nosso." ${ }^{118}$

O governador mandou que dessem o recado a Nzinga e aos sobas para que prestassem obediência a Are a Kiluanje, "e rendão por ser seu verdadeiro subcessor legitimo e natural senhor", sob ameaças de guerra. Este recado deveria ser espalhado por bandos em português e em kimbundo, "para ser notório a todos e a guerra ficar não somente justa mas justificada por ser contra rebelião notória" ${ }^{319}$.

Deu ordem também para que todos os kimbares que se recolhessem a seus antigos donos seriam perdoados. Ofereceu recompensa a quem entregar Nzinga, ficando alforriado, se cativo e recebendo mercê. Fernão de Sousa tentou organizar a guerra preta, liberando as mulheres e a quicumba, deixando apenas os homens de arco e quilambas e proibiu a deserção sob pena de morte.

A perseguição a Nzinga é bem explicitada: "Procurarseha por todas as vias aver as maõs Dona Anna Ginga viva". ${ }^{320}$ O governador expressou receio diante da possibilidade de Nzinga se unir aos Jagas que estavam na Tunda e mandou impedir esta passagem. Por fim, transferiu a responsabilidade de combater Nzinga a Are a Kilunje, que deveria dar continuidade à perseguição, caso ela fugisse.

A escolha de Are a Kiluanje para assumir o trono do Ndongo não foi fortuita. Ele era "da estirpe Real dos Reys antigos de Angola e Dongo"321, descendente de uma importante linhagem que no passado deteve a insígnia Ngola. Talvez por isso Fernão de Sousa o tenha chamado de legítimo. Para Are a Kiluanje, a aliança com os portugueses representava uma oportunidade de recuperar o trono do Ndongo de uma linhagem rival, a de Nzinga Ngola Kilombo Kia Kasenda (c.1575-1592), tido nas tradições orais como um usurpador, da qual descendia tanto Ngola Mbandi como Nzinga Mbandi. Segundo os estudos sobre genealogia do título Ngola traçado por Miller, o título da linhagem Are a Kiluanje era "uma posição ngola senior numa linha colateral, uma posição "irmão" do ngola a kiluanje". 322

\footnotetext{
${ }^{318}$ Regimento de Fernão de Sousa a Bento Banha Cardoso. Em Heintze, 1985. Doc.26. p.204.

${ }^{319}$ Idem

${ }^{320}$ Idem

${ }^{321}$ Cadornega. Vol.I. P.140.

${ }^{322}$ Miller, J. Poder político e parentesco. p. 84
} 
Are a Kiluanje aparecia como um excelente candidato nos planos de Fernão de Souza para fazer guerra a Nzinga e trazer o Ndongo sob o controle português. O sucesso deste plano permitiria estabelecer um governo em que os portugueses poderiam explorar o comércio, obter receitas, difundir o cristianismo e ganhar mais apoio militar. ${ }^{323}$

Apesar de a genealogia conferir possível legitimidade a Are a Kiluanje, os detentores desta posição nunca exerceram influências políticas e os Mbundo nunca os reconheceram como herdeiros do título Ngola. ${ }^{324}$ Muitos sobas não reconheceram o poder dado a Are a Kiluanje, visto como incapaz de garantir a ordem e de fazer chover (proeminência do Ngola) e passam a apoiar Nzinga na luta contra Portugal.

O plano de instalar um rei favorável aos portuguesesjá havia sido arquitetado no governo de Mendes de Vasconcelos, que quis instituir Samba Antumba como rei, sem sucesso. Colocar um aliado no poder que pudesse ter alguma legitimidade na tradição parecia um plano melhor do que acabar definitivamente com o título Ngola através do fortalecimento dos sobados.

Nzinga tentou, através da via diplomática, impedir o apoio a Are a Kiluanje, que era formalmente um súdito seu. ${ }^{325}$ Enviou comitivas a Ambaca e a Luanda a fim de anular o acordo de vassalagem de Are a Kiluanje e propôs seu exílio. Nzinga prometeu obediência ao rei de Espanha, se dizendo cristã, e reafirmou seu desejo de paz e sua disposição para negociações.

Ao mesmo tempo, Nzinga se fortificou na ilha de Kindonga e intensificou a propaganda anti-lusitana, agregando em torno de si muitos sobas da região do Kwanza, como os sobas do Musseque e da Quissama, que já estavam levantados contra os portugueses. Are a Kiluanje, "mostrando grandes medos de Dona Ana",326, pediu soldados para o acompanharem, mas como o governador ainda esperava a ordem do rei para fazer guerra a Nzinga, prometeu-lhe que o defenderia caso Nzinga o atacasse.

\footnotetext{
${ }^{323}$ Regimento a Bento Banha Cardoso, Janeiro de 1626. Em Heintze.1985.Doc. 26. p.204-5. E História das relações entre a Angola portuguesa e Ndongo. $2^{a}$ parte, 1625. Doc. 24. P. 199-200.

${ }^{324}$ Miller, J. Poder político e parentesco. p. 84

${ }^{325}$ Aire a kiluanje havia sido avassalado por Luiz Mendes de Vasconcelos, mas o ato foi considerado injusto por João Correia de Sousa que o devolveu aos domínios de Ngola Mbandi. Em: O extenso relatório do governador a seus filhos. Em Heintze, 1985. Doc.30. p. 230.

${ }^{326}$ Extenso relatório do governador a seus filhos. 1630. p. 230
} 
No princípio de 1626, Nzinga, atacou Are a Kiluanje quando saia da fortaleza de Ambaca. Na versão que Fernão de Sousa deu a seus filhos em $1630^{327}$, Nzinga teria arquitetado o ataque e inventou uma justificativa para isto: enviara previamente emissários a feira de Bumba Aquizanzo para noticiar ao governo português que Are a Kiluanje havia lhe roubado 48 peças que ela mandava à feira e por isso havia de lhe fazer guerra. Para socorrer Are a Kiluanje, Estevão de Seixas Tigre, o capitão de Ambaca, mandou 35 soldados portugueses mais arqueiros e quilambas, que não conseguiram deter o ataque:

"matarão por dezordem três portugueses e cativarão seis que forao levados as ilhas donde Dona Ana estava com que se declarou e convocou todos os sovas que se levantassem e os do Moseque conjurados com os da Quiçama assentarão dar nos presídios (...)" 328

A morte e a prisão dos portugueses deram a justificativa que faltava para legitimar o ataque contra Nzinga e transformá-lo em uma guerra defensiva, aprovada pela junta em Luanda, "antes que sucedesse um levantamento universal". ${ }^{329}$ O governador mandou Sebastião Dias Tição fortificar Ambaca com ordem de recolher os soldados cativos. "Como ela tinha guerra em campo e se ia fazendo poderosa de gente", Bento Banha Cardoso partiu em 7 de fevereiro de 1626 para travar-lhe o combate, acompanhado do sargento-mor Antonio Bruto, de alguma gente a cavalo e dos padres Antonio Machado e Francisco Pacconio, que tentariam reduzi-la pela pregação; foram pelo Kwanza até Massangano e seguiram até as terras do soba Kiluanji Ca Caçonda.

Nzinga continuou enviando emissários para, através da diplomacia, pedir o exílio de Are a Kiluanje e evitar a guerra contra ela. Diversos mucunzes (embaixadores) foram levar recados e uma carta de "Ana, rainha de Dongo" ${ }^{330}$, em que ela jurava obediência ao rei de Espanha, como cristã que era. Nzinga dissimulava todas as acusações que a ela se faziam e ironicamente, terminou a carta pedindo ao governador presentes, como redes, colchas, toalhas de mesa de renda e um chapéu de sol grande de veludo azul. Cardoso respondeu-lhe, em carta de 15/3/1626, pedindo a restituição dos Kimbares.

\footnotetext{
${ }^{327}$ Extenso relatório do governador a seus filhos. 1630. Em Heintze, 1985 doc.30. p. 240-241

${ }^{328}$ Carta de Fernão de Sousa ao Governo. 9 de Julho de 1626.Em Heintze, 1988. doc.78. p. 167.

${ }^{329}$ Extenso relatório do governador a seus filhos. 1630. Em Heintze, 1985 doc.30. p. 241

${ }^{330}$ Assim vai assinada a carta que Nzinga mandou às terras de Kiluanji Ca Caçonda, em 3/3/1626. Transcrita no Extenso relatório do governador a seus filhos. 1630. Em Heintze, 1985 doc.30. p. 245.
} 
Como Nzinga não o atendeu, Cardoso foi ordenado a atacá-la nas ilhas do Kwanza em 1626, dando início à primeira séria das grandes campanhas militares que tentaram submeter Nzinga militarmente. ${ }^{331}$

Bento Banha Cardoso foi informado de que todos os partidários de Nzinga se encontravam nas ilhas do Kwanza e eram demasiado fracos para fazerem frente aos exércitos portugueses. Mas o sentimento anti-português se espalhava entre os sobas, principalmente entre aqueles dominados recentemente no governo de Luiz Mendes de Vasconcelos. Estavam levantados os sobas do Lucala, do Kwanza, do Musseque, e da Quissama. Apenas os sobas do Lumbo e Ilamba e os do entorno de Ambaca permaneceram fieis aos portugueses. $\mathrm{Na}$ análise de Heintze, no tempo da primeira ofensiva de Fernão de Sousa, poucos sobas eram publicamente favoráveis a Nzinga ou apoiaram seu ataque a Are a Kiluanje. Seus partidários encontravam-se fortificados na ilha de Kindonga, ao passo que, em terra firme, ninguém se opunha abertamente aos portugueses. Heintze coloca que, neste momento, a resistência aos portugueses não significava necessariamente o apoio a Nzinga:

“o objetivo desses sobas era provavelmente uma autonomia e não outra dependência. A resistência nestas zonas era de natureza essencialmente passiva e manifestava-se em casos extremos, pela recusa de apoio militar". 332

A partir dos primeiros ataques, Nzinga começou a se transformar num símbolo da resistência anti-portuguesa muito para além das fronteiras do Ndongo, verificado pela solidariedade dos sobas Ambuíla e Kiluanje Cacango, ambos vassalos rebeldes de Portugal que se recusavam a pagar os tributos. A ruptura de relações dos portugueses com Ambuíla levou ao fim da feira em seu território, afetando seriamente o comércio de escravos.

Foram várias as batalhas que Nzinga travou contra a obstinada perseguição de Fernão de Souza, que a tinha como "capital inimiga”. Utilizamos aqui a História Geral das Guerras Angolanas, do capitão Cadornega como fonte histórica privilegiada para os episódios militares. Apesar de ter chegado a Angola somente em 1640, Cadornega se propoz a dar conta dos avanços da conquista lusa, registrar os juízos e sentimentos que os portugueses tinham daquela rainha, sobretudo porque seu sogro participou destas

\footnotetext{
${ }^{331}$ livros de Fernão de Souza, tomo I, fl. 230-231. Em nota do anotador de Cadornega. Vol. I.p.153.

${ }^{332}$ Heintze. Angola nos séculos XVI e XVII. p.349.
} 
batalhas como conquistador e posteriormente lhe narrou os episódios. ${ }^{333} \mathrm{O}$ "Extenso relatório do governador a seus filhos" ${ }^{334}$ também é um importante fonte para estas guerras, já que Fernão de Sousa fez uma retrospectiva pormenorizada dos principais fatos, citando as cartas enviadas pelo capitão mor Banha Cardoso, que lhe relatava tudo o que ocorria nas ilhas.

Nzinga havia se fortificado na ilha de Kindonga desde que seu irmão ali falecera e transformou a ilha em uma potente fortaleza militar, onde estocou grande quantidade de mantimentos e armas. Nzinga e seus combatentes conheciam muito bem a geografia do local e usaram os braços do rio Kwanza para se proteger, movimentando-se de uma ilha a outra para enganar os opositores.

Em maio de 1626, as tropas de Bento Banha Cardoso atacaram a ilha do Tendala, fazendo grande captura de gente, porém a maioria dos negros fugiu frustrando as expectativas dos portugueses.

Ataques surpresas às tropas portuguesas faziam parte do rol de estratégias de Nzinga. Em junho de 1626, Bento Banha Cardoso alojou seu exercito na outra banda do Kwanza, esperando invadir Kindonga. Nzinga, ao perceber a vizinhança indesejada e aproveitando que o sargento mor saíra com alguns soldados para buscar mantimentos, mandou os seus melhores capitães atravessarem aqueles braços de rio em canoas, balsas e jangadas, à noite, e ordenou que queimassem os alojamentos portugueses e desamarrassem as lanchas que iriam atacá-la.

Quando os portugueses finalmente conseguiram entrar na ilha de Kindonga, degolando e aprisionando muita gente, a rainha não foi capturada. Ela se movera rapidamente pelas ilhas do Kwanza, enganando os exércitos lusitanos e conseguiu fugir da implacável perseguição portuguesa. A batalha na ilha de Mapolo ocorreu no dia 12 de julho de 1626 e mostra a astúcia de Nzinga para se livrar do cerco: ${ }^{335}$

"veyo só a ficar por render a Ilha em que estava a Rainha Ginga Dona Anna de Souza com sua Corte e do melhor que possuhia; vendose Ella abarbada mandou seus Embaixadores ao Capitão mor, pedindo-lhe a não apertasse tanto, que bastava o damno e guerra que lhe tinha

\footnotetext{
${ }^{333}$ Cadornega. Vol. I. p. 136.

${ }^{334}$ Extenso relatório do governador a seus filhos. Em Heintze, 1985. Doc. 30. Pp: 252-253.

${ }^{335}$ Cadornega. Vol. I. p. 137. ; Heintze, 1985. Doc.30. Heintze, 1988. doc. 78
} 
feito nas mais ilhas, que Ella queria serfilha de Maniputo e sua Vassalla que dentro em tres dias viria em pessoa com sua Corte ao Arrayal (...)" 336

Maniputo era a forma como os Mbundos chamavam o rei de Portugal, assim a rainha negociava sua vassalagem em troca de sua liberdade. Mas quando os portugueses entraram na ilha, após os três dias requeridos, perceberam que esta estava deserta e que haviam sido enganados. Nzinga fugira com seus guerreiros e o pedido de trégua foi apenas uma artimanha, "um estrategema" ${ }^{337}$ para evitar seu rendimento real.

Cavazzi, provavelmente a partir dos relatos de Nzinga na década de 1660, registrou a consulta que ela fizera ao Xinguila de Ngola Mbandi nesta batalha. Xinguila era a evocação de um espírito que se manifestava e que Nzinga usava como um conselho político deliberativo, através do qual governava. O irmão a orientou: "render-se aos portugueses significaria a perda da liberdade. Não era indigno dela fugir naquela conjuntura, para combater e vencer o inimigo em condições mais favoráveis." 338

Cadornega afirmou que Nzinga fugiu para a província de Ango, “iludindo os inimigos." Fernão de Sousa relatou que Nzinga colocara fogo na ilha para que não encontrassem mantimentos e fugiu para Tunda (Libolo). Os exércitos não puderam segui-la, pois estavam enfermos e não sabiam seu paradeiro. ${ }^{339}$ Bento Banha Cardoso intimou todos os sobas, através de propostas de amizade e ameaças de guerra, a entregarem Nzinga caso ela entrasse em seus territórios e partiu para Samba Aquizenzele, na fronteira do Ndongo, com oitenta soldados para prendê-la. A fome e uma epidemia de varíola dizimaram grande parte da guerra preta portuguesa e matou Are a Kiluanje, levando a coroação de seu irmão Ngola Are em outubro de 1626.

\subsection{Nzinga Tembanza}

Nzinga Mbandi jamais aceitou perder o trono do Ndongo e buscou se fortalecer militarmente para combater os portugueses e garantir, pelas armas, seus direitos e a soberania de seu povo. Para fazer frente ao poder lusitano, Nzinga mobilizou muitos

\footnotetext{
${ }^{336}$ Cadornega. Vol.I. p. 137. grifo nosso

${ }^{337}$ Cadornega. Vol.I p. 139

${ }^{338}$ Cavazzi. Vol. II. P. 78

${ }^{339}$ Carta de Fernão de Sousa ao governo. Em Heintze, 1988. doc.78
} 
sobas nas adjacências do rio Kwanza, alguns sobas Ndembos e os "belicosos" sobas da Quissama. Cadornega diz que Nzinga liderou a formação de uma grande “confederação", cujo principal objetivo era eliminar a presença lusitana em Angola. ${ }^{340}$ Dentre os aliados que Nzinga obteve em sua luta contra a invasão portuguesa, um grupo se destaca: os guerreiros Jagas-Mbangala.

Não se sabe ao certo o momento que Nzinga efetivou sua união com os Jagas. As fontes são contraditórias neste ponto. Cavazzi diz que, para ter acesso a seu sobrinho herdeiro, fingiu amor ao Jaga Caza e com ele se casou segundo os ritos daquele povo, "para poder dispor de guerreiros mais aptos a tão grande empreendimento, abraçou a seita dos Jagas e tornou-se chefe da mesma." ${ }^{341}$ Assim, para este autor, a união com os Jagas aparece em momento anterior ao golpe de Fernão de Sousa, logo após a morte de Ngola Mbandi.

Cadornega escreveu que quando a rainha estava em Kindonga já contava com o apoio dos Jagas:

"Deste sitio e alojamento marchou o Capitao mor em demanda das Ilhas de Quindonga onde a Rainha Ginga estava fortificada, assistida de muitos Jagas, como era Caza e Caiete, que aquella astucioza Rainha com seus ardis e industria se havia assenhoreado delles e de seus Quilombos." ${ }^{342}$

No relatório que Fernão de Sousa enviou a seus filhos, lê-se que em maio de 1626, Nzinga estava aquartelada nas ilhas do Kwanza, mas em terra firme não tinha kilombo e não era acompanhada pelos Jagas. Diz que o Jaga Caza estava na Quina (em Ganguela) e Cassanje estava nos Malembas. ${ }^{343}$ Somente após a fuga das ilhas, ao fugir pelas terras de Ambolo Casague, onde seu exército foi acometido por varíolas, que Nzinga, fragilizada, pediu ao Jaga Caza que a recolhesse. Na narrativa de Fernão de Sousa, o Jaga teria hesitado em protegê-la alegando que ela matara o sobrinho- seu protegido- e que já havia rei eleito em Ndongo, a quem deveria obedecer, mas depois mandou chamá-la e a acolheu.

\footnotetext{
${ }^{340}$ Cadornega. Vol. I. p. 82 e seguintes.

${ }^{341}$ Cavazzi. Op. Cit. Vol.II. p.71-2.

${ }^{342}$ Cadornega. História Geral das Guerras Angolanas. . Vol.I. p. 130

${ }^{343}$ Extenso relatório do governador a seus filhos. Em Heintze, 1985. Doc.30.pp.251-252
} 
Glasgow afirmou, sem sustentar-se, que Nzinga era "em parte Jaga e em parte Mbundo- Jaga através de seu tataravô e Mbundo através de sua mãe." 344 O autor vinculou a dinastia Nzinga Ngola a Kiluanje aos Jagas, há algumas gerações, e afirmou que Nzinga nascera Jaga e fora educada para assumir a liderança de ambos os povos desde pequena.

Heintze, em consonância com as fontes de Fernão de Souza, afirmou que somente a partir da fuga de Kindonga que Nzinga conseguiu refúgio junto ao Jaga Caza Cangola e ganhou o mais importante título feminino do Kilombo, o de Tembanza, que quer dizer senhora ou dona da casa. Nzinga assumiu o papel de sacerdotiza do ungüento Magia a Samba, capaz de tornar os guerreiros invencíveis e passou a ser rigorosa no cumprimento das leis Kijilas, que proibiam, entre outras coisas, a procriação no interior do Kilombo. ${ }^{345}$

Sabemos que Nzinga assumiu a liderança de um ou mais bandos Jagas e passou a comandá-los política e militarmente na luta contra os Portugueses. A narrativa de Cadornega descreve a grandeza do contingente bélico de Nzinga unida aos Jagas: "como a Rainha Ginga estava dali distancia de Legoas, com Quilombo tumgado ou aquartelado que tomava legoas o que occupava por sua grandeza e multidão de gente e Quilombos de Jagas". 346

Miller analisa que Nzinga se uniu aos Mbangala devido à traição do acordo de paz por parte dos portugueses e a nomeação de um rei de uma linhagem opositora a forçou a procurar em outro lugar um significado para sua sobrevivência política. O autor defende que Nzinga teria origem humilde e nenhum status de linhagem que pudesse lhe permitir a ascensão ao título Ngola e por isso buscou diferentes apoios fora do estado Mbundo. A aliança com bandos de guerreiros Mbangala coube muito bem nos anseios de Nzinga. Muitos destes bandos guerreiros haviam entrado pouco antes nas terras Mbundo, vindos dos altos platôs ao sul do Kwanza, e eram hostis tanto a Mbundos como a portugueses nos anos de 1620. Segundo Miller, o apoio dos Mbangala ao sul do Kwanza ofereceu vantagens para Nzinga enfrentar sua falta de parentesco real, através da ação militar pela proficiência de seus generais, e ideologicamente, já que eles haviam

\footnotetext{
344 Glasgow. Nzinga. P.41.

${ }^{345}$ Heintze. Angola nos séculos XVI e XVII. P.344

${ }^{346}$ Cadornega. Vol. I. p.149.
} 
abolido todas as linhagens e "eram provavelmente preparados para tolerar o status anômalo de Nzinga". ${ }^{347}$ No olhar de Miller, Nzinga tentou aumentar seu poder pessoal pela manipulação da boa vontade dos Mbangala para garantir seu poder político e a posição de tembanza no bando liderado por Caza, um dos mais poderosos líderes Mbangala ao sul do Kwanza. Isso foi uma cerimônia celebrada metaforicamente pelo termo "casamento" pelos Mbundo e aceito em sentido literal pelos portugueses. Ela teria então convencido Caza a sustentá-la como herdeira legítima de Ngola Mbandi e introduziu seus próprios seguidores nas táticas militares e feitiços mágicos dos Mbagala. Miller diz que Nzinga manipulou toda a legitimidade política do título tembanza para erguer exércitos para atacar seus mentores cristãos repudiados. A associação com os Mbangala garantiu vantagens estratégicas a Nzinga, como a formação de um firme comando do lado sul do Kwanza que a permitiu um refúgio próximo onde os exércitos portugueses não poderiam penetrar. As ilhas de Kindonga no médio Kwanza, próximo ao território de Caza no Libolo, tornou-se seu retiro favorito nos tempos de guerra, e ela lançou várias expedições dali para quebrar o tráfico de escravos dos portugueses.

Nzinga e o Jaga Caza percorreram grande parte do Ndongo fugindo da perseguição do capitão-mor Bento Banha Cardoso em uma intensa campanha antilusitana e conseguiram agregar muita gente em seu kilombo. Em 1628, retornaram a ilha de Kindonga, onde se fortificaram:

"Dona Ana de Souza Gingua Ambande tornou pera as ilhas chamada dos sovas da Coanza acompanhada do Jaga Caza dizendo hera senhora e ElRei Angolla Ayre escravo seu, e queria avassalarse a Vossa Magestade, e pagar tributo do Reyno, e que elle o pagasse das terras que lhe ficarão de seu pay." 348

Ao lado de Caza, Nzinga guerreava como Jaga e atuava diplomaticamente como cristã. Ao mesmo tempo em que se fortalecia militarmente para evitar os ataques, quereria convencer os portugueses a cancelarem o apoio a Ngola Are, dizendo-se "filha do governador". Bento Banha Cardoso foi ordenado a "reprimir" Nzinga acompanhado pela gente de Ngola Are. ${ }^{349}$

\footnotetext{
${ }^{347}$ Miller. Nzinga of Matamba in a new perspective. P.209.

${ }^{348}$ Carta de Fernão de Souza ao Governo.10 de Julho de 1628. Em Heintze, 1988. p. 197. Doc. 105

${ }^{349}$ Carta de Fernão de Souza ao Rei não enviada. fins de julho ou princípios de Agosto de 1628. Em Heintze, 1988. p.200. doc. 107.
} 
Numa tentativa diplomática de anular o tratado de vassalagem de Ngola Are, Nzinga e o Jaga Caza mandaram para a fortaleza de Ambaca quatrocentas peças de escravos e cento e cinco vacas como presente ao governador Fernão de Sousa, acompanhados pelo Mani Lumbo, um importante funcionário do Kilombo que tratava das relações externas. O emissário declarou que Nzinga Mbandi se dizia "filha" do governador e que gostaria de fazer feiras. Pedia para suspender a guerra contra ela, "porque queria se quietar por estar cançada de andar pelos matos" e requeria autorização para se estabelecer na "ilha da imbilas". ${ }^{350}$ Alvaro Roiz, capitão de Ambaca, não acreditou nas intenções do Mani Lumbo e mandou prende-lo. Ao ser questionado sobre o paradeiro de Nzinga e quais sobas a acompanhavam, o emissário respondeu que ela estava em Bange, uma terra firme junto ao Kwanza, acompanhada apenas pelos sobas Macange e Sungo Amoyssa.

Ao saber da prisão do Mani Lumbo, Nzinga mandou mais dois embaixadores a Ambaca, que deram seu recado: ela queria se "meter debaixo do emparo do capitão e morrer a seus pés." ${ }^{351}$ Seria fingimento de Nzinga? Os portugueses foram informados que, ao mesmo tempo em que mandou os emissários a Ambaca, Nzinga atacou o soba Candelle dos Quezos, "onde estavam muitos pumbeiros e quimbares dos portugueses a que tomou fazendas e peças" e depois foi para o Mbondo, onde atacou Andala Quesuba $^{352}$, um importante ponto comércio escravista. Diante destes ataques, os portugueses concluíram que o Mani Lumbo fora enviado como espião, e enganara o capitão Bento Banha Cardoso ao mandá-lo a Bange. Entenderam que as milongas (recados) enviadas pelos embaixadores serviram para Nzinga ganhar tempo e melhor articular sua fuga, ao mesmo tempo em que desarticulava o comércio de escravos no Quezo e junto a Andala Quesuba. Decretou-se então a morte pública do Mani Lumbo:

"Mandeyo prender por espia, e degollar na fortalesa com que os sovas se reportarão, e ElRey (Ngola Are) tomou confiança, e cobrou animo porque lhe parecia que aceitando

\footnotetext{
${ }^{350}$ Imbila (mbila) significa sepultura, designando a Ilha de Kindonga, onde morreu seu irmão Ngola Mbandi e estavam enterrados os antigos Ngolas. Em "O extenso relatório do governador a seus filhos". Heintze, 1985. Doc.30. P.297

351“ 'O extenso relatório do governador a seus filhos”. Heintze, 1985. P.300.

${ }^{352}$ Idem. P.299-301
} 
eu as peças de escravos que ella e o jaga me mandavão o não sustentaria no reyno, nem cumpriria a escretura que me avia feito." ${ }^{\text {353 }}$

O Jaga Caza, ao saber da prisão do Mani Lumbo, abandonou Nzinga, que foi para ilha Cataxecacollo. A morte do emissário provocou a separação definitiva entre Nzinga e o Jaga Caza, que acreditava na via diplomática para evitar os litígios. A atitude dos representantes do governo demonstrou que os portugueses não acreditavam mais que Nzinga pudesse se avassalar livremente e já não acreditavam em seu discurso cristão e em suas promessas de obediência. A morte do Mani Lumbo também fortaleceu a confiança de Ngola Are no trato com os portugueses.

Após a separação do Jaga Caza, Nzinga continuou exercendo papel de liderança nos bandos Jagas. Em Cadornega, lê-se que outros bandos de Jagas lutavam sob o comando de Nzinga, "sob suas bandeiras", como era o caso do kilombo do Jaga Caiete. Mas não podemos afirmar que todos os que eram chamados Jagas lutaram a favor de Nzinga Mbandi. Alguns grupos de Jagas lutavam a favor dos portugueses, como o Jaga Calanda nesta época, mas as alianças eram sempre instáveis e a traição iminente. Os vários bandos Jagas trocam sucessivamente de lado, ora a favor dos portugueses, ora contra eles, e sua participação nas guerras era geralmente fator decisivo.

Nzinga assumiu o controle de alguns bandos Jagas, orientando-os para a guerra conforme seus interesses, e incrível poder bélico foi crucial para suas vitórias. Mas nem todos os que eram assim chamados lhe foram leais. Cardonega narrou uma passagem em que Jagas aprisionados pelos portugueses traíram Nzinga e delataram seu o paradeiro "por ella não ser Sua Senhora natural, por serem de outra casta de gente como dito he com outro Senhor ou Senhores á parte, ainda que a accompanhavão já como se forão seus vassalos. "354

Através da ajuda destes Jagas traidores e da efetiva ação militar do tendala Antonio Dias Muzungo que os portugueses chegaram ao kilombo de Nzinga e o desbarataram em 25 de maio de 1629. Para evitar ser capturada, Nzinga estrategicamente foi largando para trás suas bagagens e os prisioneiros durante sua fuga, para que os portugueses perdessem tempo os recolhendo. Para conseguir maior

\footnotetext{
${ }^{353}$ Carta de Fernão de Sousa ao governo. 10/06/1628. Em Heintze, 1988. Doc. 105. P. 198.

${ }^{354}$ Cadornega. Vol. I. p. 149 .
} 
vantagem na fuga e ganhar tempo, acabou largando também suas duas irmãs, Mocambo e Kifungi, batizadas como Dona Grácia e Dona Bárbara (antes Maria), que foram presas pelas tropas portuguesas e levadas para Luanda. Nzinga escapou de forma fantástica pela Quina Quinene (Quina Grande dos Ganguelas, localizada no vale do Lui-Kwango), descendo um despenhadeiro enorme pendurada em cipós:

"e intendendo o Capitão mor que a tinha naquella sitio encalhada e cercada por todas as partes de penhas, e da nossa guerra, quando se chegou a penetrar o dito sitio achou-se havia despencado ella e toda a gente bolante, e o mais que a pôde seguir por aquellas altíssimas brenhas, por cordas amarradas nas arvores que no mato se achão a que chamão Engungo que vem a ser como sipó do Brazil, e he materia muito forte; por ellas se forão pegando e descendo até o profundo daquellas brenhas que quando a nossa gente chegou a descubrilos parecia aquella gente lá em baixo como formigueiro de formigas, que tão alta era esta eminiencia e profunda aquella concavidade chamada Quina grande ou na sua lingoa Quineni". ${ }^{355}$

Depois desta admirável fuga, declarada como sua segunda expulsão do Ndongo, Nzinga foi para o Songo e buscou proteção junto ao Jaga Cassanje, seu antigo rival e grande inimigo dos portugueses:

"Passado isto confederou-se Jinga com o Jaga Cassanji, inimigo nosso e muito poderoso, que trazia 80 mil arcos de guerra em campo e, depois de estar com ele, este a mandou com guerra sua meter nas ilhas, com que se levantaram novos movimentos e fez repreza nos nossos." 356

Na análise de Heywood e Thorthon, Nzinga teria aceitado a "humilhante posição de mulher de Kasanje" ${ }^{357}$ e tornou-se uma Imbangala engajada em seguir as leis deste bando. Entendemos que a busca de apoio junto a Cassanje permitiu a Nzinga manter seu poder junto às comunidades Jagas-Mbagala e assegurar o prestígio que o título Tembanza lhe oferecia.

Fernão de Sousa registrou as condições em que Cassanje aceitou a dar-lhe abrigo:

"Se ella avia de yr pera ele avia de ser sem lunga que he a insígnia da guerra, e he hum gongue grande, e que ele avia de governar e não havia de aver dous senhores no seu quilombo, nem cuidasse que se avia de aver com ele como fizera com o jaga Caza e que avia de ficar sua molher."358

\footnotetext{
${ }^{355}$ Cadornega. Vol. I. p. 150.

${ }^{356}$ Cadornega. Vol. I. p. 153.

${ }^{357}$ Heywood e Thorthon.Central Africans .p. 133.

${ }^{358}$ Biblioteca de Ajuda. Cód.51-IX-20, f. 265. Em Heintze, 2007.p.367.
} 
Apesar de não ser uma fonte segura (como Fernão de Sousa teria ficado sabendo desta conversa?), a exigência revela a distinção que havia entre os bandos Jagas, em que cada um seguia as ordens de um único chefe. Cassanje era um dos mais poderosos e temidos Jagas do século XVII e não queria que a política seguida por Caza repercurtisse em seu kilombo. A abdicação da insígnia lunga significa a renúncia, por parte de Nzinga, à autoridade central do kilombo, que ela gozava ao lado de Caza.

Miller chama atenção para o caráter transitório da aliança de Nzinga com os Mbangala do sul, assim como foram todas suas outras associações. Defende que Nzinga era ilegítima também para os Mbangala e o abandono por parte de Caza deveu-se a sua "ausência de ancestralidade", assim Nzinga tinha dificuldades em manter uma base política firme, até mesmo como tembanza.

Em nossa análise, ao se tornar uma Jaga, Nzinga passou a contar com grande número de guerreiros bem treinados e altamente organizados, como prescrevia a hierarquia do kilombo, e assim aumentou significativamente seu poder bélico e garantiu sua segurança para se movimentar. A função ritual que assumiu no kilombo através do título tembanza, fez reviver a lenda de Temba Ndumba e seus guerreiros imortais, agrupando vários bandos chamados de Jagas em uma ideologia comum. A figura de Temba Ndumba possivelmente não era venerada por todos os bandos Jagas até então, e devia fazer parte da mitologia de origem apenas do grupo descendente de Zimbo e Kulembe, o marido assassino de Temba Ndumba.

Acreditamos que lutar ao lado de Nzinga imprimiu consciência política aos bandos Jagas. Estes povos guerreiros viviam vagando sem se prenderem a linhagens, roubando comidas e pessoas. Ao colocarem seus kilombos- "máquinas de guerra"359 - à disposição de Nzinga, passam a compor a frente de resistência contra a ameaça estrangeira, encontrando uma razão de ser e guerrear muito maior do que o aprisionamento de Mbundos visando o enriquecimento pessoal, que a nosso ver, tal enriquecimento dos chefes Jagas não existiu de fato: os europeus trocavam os escravos por bebidas alcoólicas e armas de fogo, que serviam apenas para sustentar a própria indústria da guerra e não traziam benefícios em termos de aquisição de bens ou prestígio.

${ }^{359}$ A ideia do "Kilombo como máquina de guerra" é apresentada por Miller,J.Poder político e parentesco. Cap. VI. 
Mas o que representou uma mulher assumir a liderança dos Jagas? O título de tembanza já era importante na organização dos kilombos, mas desempenhava uma função ritual: a de preparação do unguento Magi a Samba. Nzinga Mbandi certamente extravasou esta função e desempenhou importantes papéis de comando e direção da guerra, apresentando-se inclusive como guerreira armada em campo, não desempenhou apenas papel simbólico. Entendemos o kilombo Jaga como uma organização social eminentemente masculina, em que o princípio feminino era anulado, principalmente através da negação da maternidade, já que segundo as leis Kijila as mulheres eram obrigadas a parir seus filhos fora dos limites do kilombo, nas matas, e eram proibidas de retornarem com as crianças para seu interior. Esta proibição reforçava a negação das linhagens, próprio da identidade do kilombo, já que ninguém sabia quem eram seus pais e reconheciam apenas a autoridade do chefe do kilombo. O ritual de feitio do Magi a Samba reforça esta negação, uma vez que foi fabricado pela primeira vez por uma mãe que decidiu matar seu filho, ou seja, uma decisão pela anulação da maternidade, pela ruptura dos laços familiares ou de linhagem.

Atentando-se para o lugar social das mulheres no kilombo, percebemos que inicialmente elas iam para a guerra mas desempanhavam apenas as tarefas domésticas, auxiliando no preparo de alimentos, servindo aos homens. Nzinga Mbandi, ao assumir o comando dos Jagas, mostrou que as mulheres eram capazes de pegar em armas e irem para o campo de batalha, promovendo assim um novo lugar social para as mulheres naquela sociedade.

Nzinga Mbandi atuou, durante décadas, como fiel cumpridora das leis Jagas, que seriam válidas para todos os bandos, mesmo aqueles que lutavam a favor dos portugueses. Um episódio em especial revela como Nzinga se preocupava em seguir os preceitos Jagas: na batalha dos Empures (aproximadamente em 1640, no governo de Pedro César de Menezes), Nzinga massacrou as tropas inimigas e capturou centenas de combatentes, que foram prontamente decapitados. Apenas o padre Jeronimo de Siqueira, dois brancos e quatro soldados pardos foram poupados e o Jaga Cabucu, que servia aos portugueses, e a sua mulher:

"ao Jaga Cabucu com sua mulher, ou concubina chamada Coanza, também concedeu a vida por serem Senhores de Quilombo, e haver pacto entre os Jagas darem aos fidalgos Senhores de Quilombo boa passagem e quartel, tendo entre elles sobre isso tomado juramento a seu 
modo, e como ella uzava todos os ritos e Ceremonias Jagas e disso muito se prezava, observava grandemente os seus costumes." 360

Nzinga assumiu não apenas a posição feminina mais importante na hierarquia Jaga, mas assumiu o comando militar efetivo destes guerreiros. Sua personalidade agrupou a liderança politica e ritual de alguns bandos Jagas, extrapolando os limites de um só kilombo. Nzinga conseguiu reunir milhares de guerreiros altamente treinados e disciplinados sob seu comando, não apenas Jagas de um ou outro kilombo, mas pessoas de diversas origens e linhagens que buscavam escapar do jugo da escravidão e a enxergaram como condutora de tal liberdade.

\subsection{Ilegitmidade de Ngola Are.}

Enquanto Nzinga se fortalecia com os kilombos Jagas, o governo de Fernão de Sousa buscava uma forma de manter no poder um rei aliado. Are a Kiluanje morreu acometido por varíolas e seu irmão, Ngola Are, foi “eleito" em 12 de outubro de 1626.

A morte de Are a Kiluanje por varíolas é um fato que até hoje não chamou atenção dos historiadores ocidentais, mas podemos entender esta doença na lógica do universo Mbundo do século XVII. Cavazzi, na sua longa descrição das crenças dos povos da África Central ${ }^{361}$, listou uma série de sacerdotes especializados em curar e também provocar males, dentre eles, há um que manipulava a varíola e tinha o poder de adoecer, curar ou matar alguém. A manipulação da varíola por sacerdotes é conhecida em outros lugares da África, onde sacerdotes ou entidades são relacionados com a moléstia, como Sakpata, o Deus da varíola no Daomé e Obaluê, Omulu ou Soponna, orixás do panteão yorubá. A varíola era uma doença entendida como um castigo das divindades sobre os humanos e uma pessoa jamais morreria naturalmente desta doença:

"assim como as sete pragas do Egito eram um castigo de Jeová, o povo de Danxome entendeu que a divindade ancestral Sakpata, castigava com as epidemias de varíola o despotismo do rei que não representava mais os interesses das velhas linhagens locais, e os desvios provocados nas tradições pela dominação estrangeira." 362

\footnotetext{
${ }^{360}$ Cadornega. Vol. I. p. 352-353.

${ }^{361}$ Cavazzi. Op. Cit. Vol.I. p. 80-133

${ }^{362}$ Claude Lépine. Dois Reis Do Danxome Africa Sakpata Oduduwa: Varíola e monarquia na África Ocidental. Cultura acadêmica, 2000. Sakpata também é conhecido como Xapanã.
} 
Na visão de mundo compartilhada pelo povo Mbundo, a morte de Are a Kiluanje por varíola poderia ser entendida como um feitiço mandado por um inimigo, e provavelmente os rumores culpariam a sua principal inimiga: Nzinga Mbandi. Are a Kiluanje morreu durante as campanhas de Bento Banha Cardoso em 1626, em que cerca de quatro mil soldados que lutavam ao lado dos portugueses - brancos e negros - foram contaminados por varíola. Este episódio pode ter fortalecido a crença de que Nzinga era uma grande feiticeira, temida por todos, capaz de manipular as mais terríveis doenças. Tal crença teria sido reforçada pelo fato de Nzinga ter contraído a doença e ter se recuperado, o que era coisa bastante incomum. ${ }^{363}$

A coroação de Ngola Are como rei do Ndongo aparece na documentação de Fernão de Sousa como "eleição". Mas quem elegeu Ngola Are como rei do Ndongo? Desde a morte de Ngola Mbandi, Fernão de Sousa defendia a convocação de sobas e makotas que tradicionalmente elegiam o rei para que o processo tivesse legitimidade entre a população do Ndongo. Desejava que fosse eleito "rei legitimo e natural sucessor" do reino, mas sob a condição de ser vassalo, fazer feiras e pagar 100 peças anuais de tributo. ${ }^{364}$ Apesar do desejo de parecer um processo legítimo, poucos sobas participaram da dita eleição, que foi comandada por Bento Banha Cardoso e padres jesuítas que conheciam o quimbundo. Em 12 de outubro de 1626, Ngola Are foi eleito rei do Ndongo nas terras do soba Kiluanje Ca Caçonda. ${ }^{365}$ A nova capital do reino do Ndongo passou a ser as Pedras de Maupungo (Matadi ma upungu, pedras altas), uma fortificação natural de penedos, localizada na província do Are, onde residia Ngola Are. A localidade ficou conhecida posteriormente como Pungo-a-Ndongo, para onde foi enviado o padre Francisco Pacconio, a quem caberia orientar o novo rei como proceder nas "coisas dos brancos" e iniciar os trabalhos de evangelização do reino. O governador mandou também a Pungo-a-Ndongo o capitão Bento Rebelo Vilasboas para advertir Ngola Are de suas obrigações, enquanto o capitão-mor Bento Banha Cardoso ficava em Ambaca. Ngola Are mandou em 31/5/1627 seu filho a Luanda para se batizar, recebendo o nome Francisco. O rei foi batizado em 29/6/1627 e recebeu o nome Filipe $^{366}$, em homenagem ao rei da União Ibérica, a quem jurou obediência.

\footnotetext{
${ }^{363}$ Extenso relatório do governador a seus filhos. Em Heintze, 1985. Doc.30.pp.253-256.

${ }^{364}$ Extenso relatório do governador a seus filhos. Em Heintze, 1985. Doc.30.pp. 253

${ }^{365}$ Cadornega. Vol.I. p.154, notas do anotador . E no Extenso relatório do governador a seus filhos. pp.253

${ }^{366}$ Extenso relatório do governador a seus filhos. p. 287.
} 
A decisão de coroar Ngola Are como rei do Ndongo trouxe descontentamentos a muitos sobas, que se recusaram a obedecê-lo. A insubordinação se alastrou prejudicando a disponibilidade de soldados para a guerra preta e o pagamento dos tributos. Quando os portugueses quiseram assegurar a lealdade dos sobas da região dos Quezo, nenhum deles obedeceu à ordem do capitão mor Azevedo para se apresentar no acampamento do exército, no entanto mandaram informar ao comandante português que estariam dispostos a obedecer a seus comandos, desde que isso não implicasse submissão a Ngola Are. ${ }^{367}$ Os portugueses interpretaram isso como um apoio a Nzinga, dando ordem de guerra legítima contra os sobas do Quezo. A província de Quituxila também negou obediência ao tandala (o mais alto funcionário) de Ngola $\mathrm{Are}^{368}$, colocando em evidência sua falta de autoridade.

Acompanhada pelos exércitos Jagas, Nzinga voltou a se fortificar nas ilhas do Kwanza em 1628, invadiu a província do Are desarticulando as feiras em Pungo-aNdongo e impediu o avanço da conquista portuguesa. Ngola Are se mostrava incapaz de conter a determinação de Nzinga em recuperar o reino do Ndongo e se "intimidou tanto que queria largar o reino" ou ir para Luanda. ${ }^{369} \mathrm{O}$ governo português financiava Ngola Are na luta contra Nzinga para mantê-la ocupada, enquanto tentava desenvolver o tráfico negreiro em Andala Quesuba e em outras partes. Mas Nzinga conseguiu estabelecer suas tropas de forma a impedir a comunicação entre Ngola Are e o governo português em Luanda, e frequentemente comandava ataques às incipientes feiras e caravanas ou atacava os presídios portugueses. O governo português tentou estabelecer novos tratados de paz com Nzinga, com a promessa de devolver os territórios injustamente tomados e de ajudá-la contra seus inimigos, sob a condição de ela reconhecer estes favores com um tributo anual. Cavazzi registrou o episódio segundo o que a própria Nzinga lhe narrou anos depois:

"Alterou-se extremamente a feroz rainha com estas propostas, julgando que era grave afronta pretender homenagem duma soberana independente e absoluta. Respondeu, por conseguinte, que tais pretensões deviam ser feitas a um vencido desanimado e não a quem tinha por si todos os direitos e a coragem para sustentá-los."370

\footnotetext{
${ }^{367}$ Carta de Fernão de Sousa ao governo. 25/08/1629. Heintze, 1988.Doc. 138.p. 231.

${ }^{368}$ BAL, cód.51-IX-20.fl. 256.in Heintze, 2007. p. 365

${ }^{369}$ Carta de Fernão de Sousa ao governo. 25/08/1629. Em Heintze, 1988. Doc. 138. P.230.

${ }^{370}$ Cavazzi. Op. Cit. Vol.II. p.77.
} 
A fraqueza de Ngola Are perante Nzinga era latente e Fernão de Sousa não deixou de registrar o medo que ele sentia do poder extraordinário de sua rival. Nzinga, aliada aos Mbangala, ganhou fama de imortal, pois sabia preparar feitiços que a tornava invencível: "se desconfiou ElRey e concebeo com grande medo, e receyo da Gingua pelo ameaçar [sic] com feitissos, que este gentil teme mais que armas, e não teve animo pera a cometer, nem resolução pera andar a correr a terra com a sua guerra (...)."

A visita do tendala e dos principais makotas de Ngola Are aos representantes portugueses deixa evidente a sua falta de legitimidade entre os sobas do Ndongo. Seus emissários foram mandados a Pungo-a-ndongo, em 28 de fevereiro de 1629, para se queixarem de três coisas: a primeira é que muita gente do Ndongo fugia para Matamba para ficarem livres da obrigação de servir na guerra portuguesa, e que foram aprisionados em Matamba, "como se fossem inimigos (...) assy por concluzão se queixa que com nome de querer cativar e destroyr a Ginga e sua gente tem destroydo os que ficavao em Dongo"372; a segunda coisa que queixaram foi "que grandes e piquenos não lhe tem nenhum respeito, mas o injurião com ynjurias mui graves." Finalmente reclamaram que após o ataque a um kilombo, Ngola Are partiu e quando estava a uma légua do local, suas tropas o fizeram retornar ao kilombo arruinado "dizendo que não querião mais hir pela Ginga a fazerlhe guerra", ou seja, Ngola Are havia sido abandonado pelos seus guerreiros, que passaram a recusar combater Nzinga. A carta termina assim: “ rogamos a Vossa Senhoria pelo amor de Deus a ter compaixão de nosso Rei, e nos outros que não temos outro pai e mai.", revelando a extrema dependência que Ngola Are tinha do governo português, já que não encontrava legitimidade entre os seus nem forças suficientes para vencer Nzinga.

A informação preocupou Fernão de Sousa, que averiguou as queixas com "boas lingoas" (intérpretes) e as remeteu ao capitão-mor Paio de Araújo de Azevedo. Narrou o episódio em que seis sobas foram prestar obediência ao capitão mor, que os recebeu e mandou que retornassem a suas terras. Quando estavam na Quituchela sofreram um ataque em que lhes roubaram a quicumba e toda a gente de suas morindas (gente livre). Como eles eram leais a Ngola Are e foram atacados em território do Ndongo, que está sob a proteção portuguesa, este episódio mostrou a fraqueza do soberano em garantir a

${ }^{371}$ Carta de Fernão de Sousa ao governo. 10/06/1628.Heintze, 1988. p. 198. doc. 105
${ }^{372}$ Queixa dos tendalas e macotas de Ndongo. 28 de fevereiro de 1629. In Heintze, 1988. p.286. doc. 196 
ordem na sua jurisdição. O intérprete narrou que os soldados rebelados de Ngola Are, após negarem-se a fazer guerra contra Nzinga, chamaram-no de cão, e que o haviam de enforcar. A que o governador comentou:

"não o creyo, porque ainda que he negro tem nome de rei, e está confirmado por Sua Magestade, e devesselhe cortezia e respeito, o que confio de Vossa Merce (Paio de Araújo) fará em tudo pera com seu exemplo se não atreverem outros a desonralo." 373

Em 15 de maio de 1629, Paio de Araujo de Azevedo conseguiu invadir o kilombo de Nzinga e suas irmãs foram aprisionadas e levadas a Luanda, onde ficaram na casa de D. Ana da Silva, mulher do capitão mor Payo de Araujo Azevedo. Fernão de Sousa declarou o amor e respeito que o povo do Ndongo sentia por estas irmãs que as considerava como "deydades". 374

Dona Gracia Kifunge, a irmã mais nova de Nzinga, afirmava que Ngola Are não poderia ser rei do Ndongo, pois era filho de uma escrava sua. A origem inglória de Ngola Are parece ter convencido Fernão de Sousa, que escreveu um importante documento apontando as razões que havia para Ngola Are não ser rei:

"Que não é legitimo sucessor do Reino, porque he filho de escrava nascido em casa d'ElRey Angola Ambande, e que he peça de sua filha Dona Gracia Quifunge e que por nascer em casa se lhe não posera marca, pelo que nenhum sova dos da casa d'ElRei lhe quer obedecer, nem o hade fazer.",375

A acusação de ser filho de uma escrava não foi negada por Ngola Are, ao contrário, ele confessou ser "peça" e mandou presentes às irmãs, mas elas não quiseram aceitar, alegando que em nenhum tempo ele poderia ser obedecido sendo elas vivas, porque a elas "diretamente pertence o reino., 376

Fernão de Sousa terminou este documento sugerindo que se procurasse Nzinga para uma "composição", pois Ngola Are já não se podia mais sustentar no reino. Dona Maria Cambo afirmava: "que elle sera are mas angolla não sera nunca, e que dona Ana

\footnotetext{
${ }^{373}$ Carta de Fernão de Sousa a Paio de Araújo de Azevedo. 20 de março de 1629. In Heintze, 1988. p. 287. doc. 197

${ }_{374}$ Carta de Fernão de Sousa ao governo. 25/08/1629. Heintze, 1988. Doc. 138.p. 231.

${ }^{375}$ A ilegitimidade do novo rei do Ndongo, Angola Aire.(s.d, entre 20 de julho e 14 de setembro de 1629). Heintze, 1985. Doc. 28. pp.209.

${ }^{376}$ idem.p.
} 
a não avião de matar, antes a deixarião passar livremente e lhe darião o necessário porque he angolla que ninguém ouza pegar."377

Eram vários os pareceres sobre quem deveria ocupar o trono do Ndongo: o bispo D. Francisco de Soveral acreditava que seria melhor entregar o reino a uma das irmãs, pois as considerava as legitimas sucessoras, apesar de considerar justa a guerra contra Nzinga; os jesuítas defendiam que Ngola Are deveria permanecer no poder, pois pagara as 100 peças referentes ao ano anterior; Nzinga declarava que não queria ser rainha, que o fosse uma de suas irmãs e ela ficaria em paz e pagaria as 100 peças anuais prometidas por Are; Fernão de Sousa defendia que Mocambo - batizada com o nome de Maria e mais tarde de Bárbara- deveria assumir o trono após casar-se com um parente próximo do falecido Ngola Mbandi que fosse favorável aos portugueses, porque era muito amada e os sobas a obedeceriam e "deste modo se concertará o reino." ${ }^{378}$ Contudo, Fernão de Sousa não se atrevia a resolver o caso sem que houvesse ordem expressa do rei. $\mathrm{O}$ governador mostrava-se desesperado com a situação caótica da conquista pois todos os sobas estavam rebelados e desobedientes, e muitos fugiam para outras terras por não haver autoridade em que confiar.

A desobediência dos sobas para com Ngola Are foi registrada em diversos documentos de Fernão de Sousa. Os sobas do Ndongo falaram, por diversas vezes, que preferiam perder a vida ou até assistir à dissolução definitiva do reino a serem vassalos de Ngola Are. ${ }^{379}$

A grande seca que acometeu o Ndongo em 1629-1630 aumentou a descrença que o povo sentia em Ngola Are, que se mostrou incapaz de provocar as chuvas, uma habilidade que o Ngola deveria ter. A situação do povo Mbundo se agravou com a fome e a disseminação da varíola, que prejudicou o pagamento dos tributos aos portugueses. Fernão de Sousa defendia que uma rígida política tributária - que punia a inadimplência com a guerra - levaria os sobas a se levantarem contra a colonização portuguesa. Desde

\footnotetext{
${ }^{377}$ idem.p. 210

${ }^{378}$ Carta de Fernão de Sousa ao governo. 25/08/1629. Heintze, 1988. p. 231. E Carta de Fernão de Sousa ao governo. 8/01/1630. Heintze, 1988. P. 244.

379 A ilegitimidade do novo rei do Ndongo, Angola Aire.(s.d, entre 20 de julho e 14 de setembro de 1629). Heintze, 1985. P.209-210. História das relações entre a Angola portuguesa e o Ndongo. 16241631, de 6/08/1631. Heintze, 1985. Doc.25. pp.203. Carta de Fernão de Sousa ao governo. 8/01/1630. Heintze, 1988. p. 244.
} 
1626, reconhecia que a guerra movida por Nzinga impedia o pagamento dos baculamentos e recomendava "suavidade" nas cobranças, pois se "apertarem" os sobas os obrigariama passar para o lado dela. No quadro de miséria generalizada, Fernão de Sousa pedia ao rei que se "flexibilizasse" a cobrança de tributos, aceitando o que cada soba poderia dar no momento. ${ }^{380}$

A tentativa de instituir um rei favorável aos portugueses mostrou-se falha, uma vez que o povo do Ndongo não o considerava legítimo. O fim do Ndongo como estado independente se iniciou com as guerras de Luiz Mendes de Vasconcelos e foi concluído com a eleição de Ngola Are, em que o reino passou por um processo de descentralização e segmentação. Heintze comenta que, nesta época, a designação de reino "não passava de um eufemismo lisonjeador". ${ }^{381}$ Grande parte dos sobas, especialmente os do oeste e das imediações de Ambaca no norte foi desvinculada do Ndongo e diretamente subordinada à coroa portuguesa.

A escolha de Ngola Are trouxe um vazio político e ritual no Ndongo, já que grande parte da população não acreditava que o novo rei poderia cumprir as prerrogativas do título que lhe fora atribuído, como presidir a primeira sementeira, consultar os ancestrais e fazer chover. Esta crise levou a centenas, ou até milhares, de pessoas migrarem do Ndongo, buscando as regiões vizinhas, como Matamba, Tunda e Mbondo, alterando substancialmente a composição étnica da população. Heintze considera que grande parte da população do Ndongo era composta por ijiku, escravos que estavam distantes das suas linhagens de origem, desta forma, duvida que o princípio Ngola ainda tivesse força para permitir que uma população não natural do país se identificasse com este reino. A organização e ideologia dos kilombos Mbangala lhes parecia mais interessante e Nzinga soube atraí-los para seu contigente. ${ }^{382}$

Ngola Are só se manteve no poder devido ao auxílio português, mesmo assim sempre com muitas dificuldades e com poder efetivo reduzido, que provavelmente não ultrapassava a sua província original. A dependência da colônia europeia se expressava pela incapacidadade de Ngola Are se defender sozinho de seus inimigos, notadamente

\footnotetext{
${ }^{380}$ Carta de Fernão de Sousa sobre os tributos de vassalagem dos sobas. 8 de julho de 1626. Em Heintze, 1985. Doc. 31. P. 365. Carta de Fernão de Sousa ao governo. 8/01/1630. Heintze, 1988. P. 244.

${ }^{381}$ Heintze. Angola nos séculos XVI e XVII. P. 379.

${ }^{382}$ Heintze. Angola nos séculos XVI e XVII. P. 382.
} 
Nzinga Mbandi, e mesmo internamente ele não conseguia garantir o funcionamento das feiras e a circulação da economia, frustrando assim as expectativas portuguesas que levaram a sua coroação.

A qualificação "rei fantoche" que frequentemente aparece na historiografia ${ }^{383}$, contudo, deve ser repensada. O termo "fantoche" indica total manipulação, ausência de vontade, absoluta subjugação aos interesses portugueses, e esconde as intenções políticas que a linhagem Are tinham. Apesar de Ngola Are ser fraco, ele também se beneficiou com o apoio dado pelos portugueses e conseguiu a ascensão política que almejava com o recebimento do título Ngola, ainda que não conseguisse fazê-lo valer de fato. Fernão de Sousa chegou a acusá-lo de se prevalecer desta relação e tentar enganar os portugueses:

"Procurou todo este tempo esfrutar o Reino, recolher nas Pedras, peças, fazendas e mantimentos por sy, pelo seu tendala e mani lumbo com [in]tenção de se hir para o Lembo e lá se afirma mandou peças e as tem, sem tratar de pagar o basculamento a sua Magestade, nem dar cousa de consideração."384

Desta forma, a repetição irrefletida do termo "rei fantoche" anula as intenções dos atores sociais que foram escolhidos como reis, que se foram manipulados, também tentaram ganhar com a situação.

\subsection{Poder feminino e legitimidade no Ndongo e em Matamba}

Nzinga Mbandi era legítima governante do reino do Ndongo ou teria, através do assasinato de seu sobrinho, usurpado o poder, a que não tinha nenhum direito? Retomamos a discussão historiográfica sobre a legitimidade de Nzinga Mbandi ao trono do Ndongo no intuito de questionar e debater as afirmações de Miller, que defendeu a tese da ilegitimidade de Nzinga. ${ }^{385}$

Na análise de Miller, o reinado de Ngola Mbandi representou uma de muitas facções linhageiras em um delicado cenário em que forças contrárias disputavam o

\footnotetext{
${ }^{383}$ Heintze. 2007. Glagow.

384 "A ilegitimidade do novo rei do Ndongo, Angola Aire". (s.d, entre 20 de julho e 14 de setembro de 1629). Em Heintze, 1985.Doc. 28.P.209.

${ }^{385}$ Miller, 'Queen Nzinga of Matamba in a new perspective', Journal of African History. Vol. XIII (I975),pp. 20I-2I6.
} 
poder político central. Com a morte de Ngola Mbandi, o poder poderia normalmente ir para qualquer um dos grupos de linhagens que combinariam manobras políticas com alinças com os sobas para estabelecer seu candidato. Facções perdedoras costumavam aceitar sua derrota como uma temporária retirada, mantendo as esperanças de um dia capturar o título real. Nenhum herdeiro direto do Ngola estava garantido no poder com sua morte, pois a sucessão hereditária não era uma regra fixa. Neste contexto, Miller levantou três razões que impediriam Nzinga de assumir o título Ngola:

1) Nzinga não era parentelegítima do Ngola para concorrer ao trono.

2) As mulheres eram impedidas de ascender ao poder

3) Nzinga era filha de escrava

Miller defendeu que Nzinga não era irmã legítima de Ngola Mbandi, pois não eram filhos de uma mesma mãe, e nas regras Mbundo de sucessão matrilinear, uma meia-irmã de uma co-esposa do pai não poderia ser considerada parente. Miller sustentou sua argumentação na origem humilde de Nzinga, que não teria status para ascender ao poder, e principalmente, não tinha apoio nas linhagens dominantes. Seus cálculos das linhagens Mbundo colocaram Nzinga longe da linha de legitimidade e da provável sucessão de Ngola Mbandi. Para Miller, Nzinga e Ngola Mbandi eram "meioirmãos", sendo Nzinga filha do oitavo Ngola com uma concubina, uma mulher que pertencia a linhagens escravas que eram dependentes da corte real, ou seja, uma kijiku.

Parreira discorda de Miller, que afirmou sem demonstrar em evidências, a falta de parentesco real de Nzinga. Parreira admite a possibilidade de eles não serem parentes, mas seguindo a linha de raciocínio do próprio Miller, o termo irmão poderia indicar não uma relação de consanguinidade entre pessoas, mas sim equivalência entre os títulos que ocupavam, o que alteraria completamente os dados do problema. Sendo Nzinga uma representante de uma linhagem que concorria ao título Ngola, o argumento de Miller sobre a "usurpação do poder" tornar-se uma contradição que deve ser posta em cheque, diz o autor português. ${ }^{386}$

Cavazzi afirmou que sua mãe era uma concubina do Ngola chamada GanguelaCacombe. ${ }^{387}$ Em nenhum momento o padre italiano disse que ela seria uma escrava ou

\footnotetext{
${ }^{386}$ Parreira, Adriano. Economia e sociedade na época da Rainha Jinga. P.181.

${ }^{387}$ Cavazzi. Vol. II. P.64.
} 
kijico, mas qual o sentido que ele atribuiu ao termo concubina? Devemos refletir sobre a composição da corte do Ngola, que tinha várias mulheres, sendo a mais importante chamada de Nvala muene, e a samba nvala, que ocupava o segundo lugar. Qual era a posição ocupada pela mãe de Nzinga? A noção monogâmica europeia contida no sentido da palavra concubina não cabe na lógica da sociedade Mbundo. E o que significava ser uma kijiku do Ngola? Para o Ngola, todos seus súditos eram seus ijiku, desta forma, o termo ganha uma dimensão mais ampla do que a simples tradução por escravo. A afirmação de que a mãe de Nzinga era uma escrava aparece apenas em Curvelier, que não a sustentou em nenhuma evidencia documental ${ }^{388}$. Por que Miller acreditou em Curvelier sem questionar a veracidade desta afirmação e a repetiu com tanta ênfase?

Não acreditamos nesta filiação, pois se Nzinga fosse realmente filha de uma escrava, isto teria vindo à tona durante a discussão sobre a legitimidade de Ngola Are em 1629, quando este foi publicamente recharçado por ser filho de uma escrava de D.Gracia Kifunge. Como vimos, o próprio governador Fernão de Sousa acreditava nesta origem inglória de Ngola Are e, em decorrência disto, passou a defender a coroação de uma das irmãs de Nzinga. Certamente, se Nzinga também tivesse esta mácula em sua genealogia, seus rivais teriam levantado esta acusação na época, mas ao contrário, a maioria dos sobas a reconhecia com "angolla que ninguém ouza pegar". 389

Prosseguindo com a argumentação de Miller, ele afirma que Nzinga tinha apenas uma filiação remota com alguma linhagem real e não poderia esperar apoio imediato para assumir o governo. Seus principais apoiadores estavam entre o povo e não entre as linhagens estabelecidas no reino. Questionamos em que Miller se fundamentou para afirmar esta falta de apoio, já que as fontes disponíveis não revelam muitas informações sobre as relações de poder internas ao reino do Ndongo no século XVII, mostram apenas a posição política que era interessante aos portugueses.

Miller é enfático ao afirmar que os Mbundo nutriam fortes sentimentos contra mulheres assumindo qualquer título politico e era explicitamente proibido a qualquer mulher assumir a posição ngola a kiluanje. Esta proibição vai contra a genealogia

\footnotetext{
${ }^{388}$ Cuvelier. Koningen Nzinga van Matamba .Brugge, 1957. P. 42.

${ }^{389}$ A ilegitimidade do novo rei do Ndongo, Angola Aire.(s.d, entre 20 de julho e 14 de setembro de 1629). Heintze, 1985. Doc. 28. p. 210
} 
apresentada por Cavazzi, em que o primeiro Ngola, o rei-serralheiro, foi sucedido por suas filhas, primeiro por Zunda-dia-ngola e depois por Tumba-dia-ngola ${ }^{390}$, marcando a presença feminina no trono do Ndongo desde sua fundação. Gaeta também registrou que a filha de Angola Bumbambula, o primeiro Ngola em sua versão, Hohoria Angola, foi obrigada a destronar seu irmão, Zunduria Angola, por sua crueldade, mas ela teria governado junto com o marido. ${ }^{391}$

Para Thornton, Nzinga sabia que, por ser mulher, encontraria maiores dificuldades para se legitimar no poder e por isto planejou casar-se como um homem dependente, que governou nominalmente como rei, enquanto ela exercia o poder real. 392 Estes maridos dependentes não foram aceitos como rei e por isso ela buscou ser reconhecida por uma segunda maneira: Nzinga decidiu “tornar-se homem". Na visão de Thornton, Nzinga passou, a partir da década de 1640, a agir como homem para atender este requerimento ideológico que restringia a participação feminina no poder. Ela passou a obrigar seus "maridos" a se travestirem e se tornarem seus "concubinos"393 e reforçou sua masculinidade ao se engajar em atividades viris, em que ela se destacava pela grande habilidade de manejar armas e comandar pessoalmente as tropas.

Cardonega remete a este caráter "travesti" de Nzinga quando os portugueses invadiram o kilombo de Nzinga, no governo de Souto Mayor (outubro de 1645 a 1646). Um soldado português que havia sido capturado na batalha dos Empures foi encontrado vestido como uma mulher portuguesa. Nesta ocasião, descobriram uma casa em que Nzinga mantinha homens vestidos como mulheres, como se fosse um harém masculino:

"Tinha esta Rainha huma grande casa que lhe servia de Serralho, sem ser o do Gram Turco, porque esta era de homens, e esse outro de Mulheres, no qual tinha suas Concubinas e Mulheres, que assim chamava áquelles tristes homens, transformados em mulheres, até em o seu vestir; era composto de muitos e bizarros mocetoens com os nomes de Emvala hinene, e Samba Amzila; e não sahião dali, se não com grande prevenção; e era pena de morte inviolável aquele que se achasse comprendido em adultério, como se elles fossem fêmeas, e ella Varão; e nenhum dos seus lhe chamava

\footnotetext{
${ }^{390}$ Cavazzi. Descrição histórica dos três reinos.p. 83.

${ }^{391}$ Gaeta. Maravigliosa Conversione... p. I4I.

392 Cavazzi fala deste casamento mas nenhuma outra fonte confirma este arranjo. Em Thornton. "Legitimacy and political power". P. 38.

${ }^{393}$ Manuscrito Araldi de Cavazzi, ' Missione evangelica', vol. A, Book 2, p. 4I' citado por Thornton. Ver Cavazzi, descrição histórica. P.38.E Gaeta. Maravigliosa Conversione... p. 218-219.
} 
Rainha, se não Rey: uzava delles para suas torpezas e deshonestidades, dando sinal aquelle que melhor the parecia." 394

O testemunho de Cardonega é importante fonte de como a imagem de Nzinga era construída no interior do exército português, pois nesta época já havia chegado a Angola e pertencia as tropas que desbarataram o kilombo. Acreditamos que este tratamento era dispensado aos prisioneiros de guerra, principalmente aos portugueses, talvez como uma forma de humilhação pública que tinham que passar perante o kilombo que os aprisionou.

Pensamos no significado que as palavras "rei" e "rainha" tinham no contexto Mbundo do século XVII. Como seus súditos se referiam a Nzinga? Ngola? Cambolo? Certamente não usavam os vocábulos em português e as representações de gênero e poder tinham diferentes acepções.

A meu ver, esta "masculinização" de Nzinga foi exagerada pelas fontes, principalmente pelos padres capuchinhos que quiseram demonstrar o quão bizarro e demoníaco era o comportamento de Nzinga enquanto viveu como Jaga.

Provavelmente, por todo o tempo em que esteve sob o comando dos Jagas, Nzinga apresentou um comportamento visto como masculino, no sentido guerreiro, transpondo o papel que as mulheres tradicionalmente tinham no interior do kilombo, dedicadas aos serviços domésticos. Nzinga comandou as tropas pessoalmente e era uma excelente lutadora, tinha força física, agilidade e sabia manusear bem as armas. ${ }^{395}$ Talvez fossem os europeus, seus opositores, que entendiam estas atividades como parte do universo masculino. Homens e mulheres ocupavam lugares sociais distintos na Europa e na África. Compreendemos que a dita "mudança de gênero" de Nzinga acompanhava as interpretações européias destes papeis sociais, o que não era necessariamente repetido em Angola. Talvez para os Mbundo não fosse algo tão extraordinário uma mulher no campo de batalha ou ocupando posições de comando.

$\mathrm{Na}$ análise de Miller, Nzinga conquistou Matamba na década de 1630, porque naquele reino tradicionalmente as mulheres governavam sem nenhuma interdição, e Nzinga foi atrás deste precedente externo para se legitimar no poder. Parreira não

\footnotetext{
${ }^{394}$ Cardonega. História Geral das guerras angolanas. Vol. I. p. 414-416. Nvala Inene era a designação dada à primeira e e samba nzila à segunda esposa.

${ }^{395}$ Cavazzi. Vol.II. p. 183.
} 
concorda com a tese da ilegitimidade defendida por Miller e discorda de que o sexo de Nzinga tenha sido o fator determinante para a conquista de Matamba, pois não acredita que esta conquista não foi efetivamente uma escolha deliberada de Nzinga. Defende que, longe de ser uma escolha, a ocupação de Matamba foi porventura a única e derradeira alternativa que lhe restou. ${ }^{396}$

Acreditamos que Muhondo a Cambolo deu o trono a Nzinga por considerá-la mais apta a lutar contra os portugueses e garantir assim a soberania de Matamba. Sabemos que Matamba e Ndongo só se tornaram estados autônomos no século XVI, e que são várias as evidências de que a insígnia Ngola tenha surgido primeiramente na região de Matamba ${ }^{397}$, sendo este estado antigamente chamado de Ndongo Oriental, o que revela uma proximidade histórica entre os dois reinos. Sendo assim, por que a cultura política haveria de ser tão diferente nos dois lugares, a ponto de um não tolerar as mulheres no poder e o outro ter isto como instituído?

Não me parece que esta interdição existia tão evidentemente no Ndongo de modo a deslegitimar Nzinga. Acredito que ela foi criada pelas linhagens rivais e sustentada pelos portugueses, que com sua visão de mundo essencialmente masculina, queriam reproduzir o rebaixado o lugar social das mulheres no universo africano. Fernão de Sousa afirmou que as mulheres não poderiam assumir o reino do Ndongo ${ }^{398}$, mas até que ponto isto representa uma realidade ancorada nas tradições daquele reino ou foi um fator apresentado pelo governador e pelas linhagens que disputavam o poder para contrapor à legitimidade de Nzinga?

Para Miller, Nzinga cometeu uma usurpação do trono, possibilitada mediante a violência com que agiu sobre seu sobrinho. Sua ascensão ao poder teria se baseado mais em suas ambições pessoais e nas estratégias dos interesses portugueses do que na aclamação de seus súditos. Miller diz que como Nzinga não tinha apoio das linhagens, iniciou uma campanha sanguinária para eliminar seus oponentes domésticos, provavelmente candidatos ao trono de coalisões linhageiras e incluindo o homem esperado para suceder o rei morto, o sobrinho. Na visão de Miller, toda a trajetória

\footnotetext{
${ }^{396}$ Parreira, Adriano. Economia e sociedade na época da Rainha Jinga. P.181

${ }^{397}$ Miller, J. Poder político e parentesco. Cap. 3

${ }^{398}$ Carta de Fernão de Sousa ao governo. 25/08/1629. Heintze, 1988. p. 231. E Carta de Fernão de Sousa ao governo. 8/01/1630. Heintze, 1988. P. 244.
} 
política de Nzinga foi uma busca por aliados externos, já que ela não tinha apoio interno no Ndongo que lhe assegurasse no poder: o batismo de 1622 teria sido uma tentativa de conseguir o apoio dos portugueses; posteriormente, contou com o apoio dos escravos fugidos das mais variadas origens; depois se aliou aos Mbangala para conseguir apoio de um grupo que não se organizava pelas linhagens; e por fim buscou se estabelecer em Matamba, onde já existia o precedente do poder feminino.

$\mathrm{Na}$ tentativa de responder a estas questões, historiados buscaram entender o conjunto de regras que regia a sociedade Mbundo no século XVII, tentando encontrar algo parecido com uma constituição que estabelecesse as regras de sucessão ao trono. ${ }^{399}$ Miller e Parreira assumiram que o Ndongo possuía uma constituição razoável que especificava quem poderia e não poderia assumir o trono. Miller concluiu que Nzinga não poderia. Parreira argumentou que sim.

Para Thornton, a constituição do Ndongo poderia ser encontrada nas tradições orais preservadas que evocavam precedentes históricos, mas não entende tal constituição como um texto explícito. Este corpus documental teria permitido a legistas do século XVII e a acadêmicos modernos descobrirem os princípios relevantes das tradições e seriam estes precedentes históricos que teriam estabelecido o direito de Nzinga governar, ou não. Mas Thornton critica a aceitação desta constituição como um conjunto de regras fixas e imutáveis. Para ele, uma constituição é imutável apenas quando a maioria dos atores políticos aceita a validade histórica ou genealógica dos precedentes e concordam em manter a pessoa ou grupo no poder. Já em situações em que as condições políticas estão mudando, a rigidez da lei constitucional rapidamente se quebra. A lei poderia ter sido estabelecida pela emergência de um rei poderoso ou por políticos estabelecidos que obrigariam os precedentes históricos a apoiá-los como legítimos. Thornton defende que no tempo da sucessão de Ngola Mbandi não havia no Ndongo "esta confortável situação de precedentes constitucionais claramente definidos", e vários grupos sociais rivais lutavam para criar uma constituição que os favorecesse. ${ }^{400}$

\footnotetext{
${ }^{399}$ Miller, Parreira e Thornton foram em busca de uma "constituição" que regia o Ndongo no século XVII. ${ }^{400}$ Thornton, J. Legitimacy and Political Power: Queen Njinga, 1624-1663. The Journal of African History. Vol. 32, No. 1 (1991), pp. 25-40. Cambridge University Press.
} 
Thornton chama atenção para a possibilidade dos grupos rivais no Ndongo citarem precedentes históricos ou mitos para suportar suas posições, criando um grande e heterogêneo grupo de precedentes diferentes e versões contraditórias da história do país. Os precedentes e as narrativas históricas que davam apoio aos governantes eram ambíguos e altamente manipulados, em função das demandas daqueles que lutavam pelo poder. Cabe aqui lembrar os ensinamentos de Jan Vansina, que defende que uma tradição oral é sempre o discurso de uma determinada linhagem ou clã que busca justificar e reivindicar, através da narrativa, "os privilégios e reinvindicações dos direitos desaparecidos". 401

Thornton defende a ideia de que a resolução real dos problemas constitucionais era definida mais por quem poderia vencer as lutas no campo material, através da organização de apoiadores ou exércitos e assim poderia impor a seus rivais a veracidade histórica dos precedentes legais que o legitimavam. Tenta entender a sucessão de Ngola Mbandi dentro da lógica eleitoral vigente no Ndongo, a partir dos documentos da segunda metade do século XVI. ${ }^{402}$ Quando os primeiros portugueses chegaram no Ndongo, em 1560, eles encontraram um estado relativamente descentralizado, em que o Ngola reinava em conjunto com vários makotas- representantes dos territórios, que representavam um bloqueio ao seu poder absoluto. Mas através da ação dos ijiku, os escravos da corte, o Ngola pôde centralizar sua autoridade no fim do século XVI. Os ijiku atuavam como supervisores judiciais e militares sobre os territórios dos sobas, recolhendo os tributos em prol do Ngola. Na visão de Thornton, os ijiku atuariam como intermediários políticos que permitiram ao Ngola ter os sobas como "clientes". Através da atuação dos ijiku junto aos sobados, garantiu-se o direito à sucessão hereditária do Ngola, reduzindo a importância da eleição dos makotas. O autor defende que foi justamente esta poderosa classe de escravos da corte que apoiou Nzinga em sua busca pelo poder, e em sua luta pelo controle dos escravos militares, os kimbares. Afirma que Are a Kiluanje era essencialmente um dikota (singular de makota) que poderia atuar

\footnotetext{
${ }^{401}$ Vansina, Oral tradition. Chicago, 1966. e Once upon a time: oral tradition as History in Africa. Daedalus.c.2.1971, 442-468.

${ }^{402}$ Thornton cita os seguintes documentos: carta de Antonio Mendes, 9/05/1563. Em Brásio. Vol. II.p. 508-510; Apontamentos sobre Paulo Dias de Novais (1560-1561), em Brásio, vol. II. P. 467-8 e carta de Francisco de Gouveia ao Jesuíta Geral, 01/11/1564. Em Brásio, vol. XV, p. 230-231.
} 
para reverter a tendência de centralização sobre os escravos reais que beneficiava Nzinga.Teria sido esta a razão fundamental para a luta de Are a Kiluanje e dos portugueses contra Nzinga.

Thornton conclui que Nzinga conseguiu formar um estado que tolerava sua autoridade e conseguiu construir uma forte base de apoiadores leais que a ajudaram a se sustentar no poder tanto quanto a relevância dos precedentes que ela citou. Nzinga assegurou o poder e o baseou em precedentes históricos, e uma vez que ela e suas sucessoras tinham vencido aqueles que questionavam sua reivindicação, ela mesma se tornou um precedente histórico. Se Nzinga teve dificuldades para governar por ser mulher, o mesmo não aconteceu com suas sucessoras. A combinação dos reinos do Ndongo e Matamba (um título que foi usado até 1756) que ela governou, teve numerosas rainhas nos séculos seguintes: no período de 104 anos que se seguiu a morte de Nzinga, rainhas governaram por pelo menos 80 anos. ${ }^{403}$

Não concordamos com as conclusões de Miller, para quem Nzinga era uma usurpadora sem direito a reivindicar o trono do Ndongo. Para nós, Nzinga era soberana legitimamente nomeada por Ngola Mbandi antes de sua morte, como as cartas do inicio do governo de Fernão de Sousa atestaram. ${ }^{404} \mathrm{O}$ assassinato de seu sobrinho foi uma forma de permanecer no poder, uma vez que ela já tinha assumido o trono como regente do menor e resguardar seu reino de um possível plano português de coroar o herdeiro "em nome de Vossa Magestade", para tê-lo como executor dos desejos lusitanos. ${ }^{405}$

A tese da ilegitimidade de Nzinga foi criada pelos governadores portugueses, principalmente por Fernão de Sousa e suas cartas revelam nitidamente esta maquinação. No inicio de seu governo, Fernão de Sousa aceitou os termos do tratado de paz e via Nzinga como legitima, somente depois da luta pelos escravos fugidos que ele começou

\footnotetext{
${ }^{403}$ Thornton, J. Legitimacy and Political Power: Queen Njinga, 1624-1663.p.40.

${ }^{404}$ Carta de Fernão de Sousa ao governo. 15/8/1624. Em Heintze. Fontes para a história de Angola. 1988. Vol.II p.85. doc. 36 e História das relações entre a Angola portuguesa e o Ndongo- 1617 a $1624.1^{\mathrm{a}}$ parte. Em Heintze. Fontes para a história de Angola.1985. Vol.I.doc.23.p.196

${ }^{405}$ História das relações entre a Angola portuguesa e o Ndongo- 1617 a setembro de $1625.2^{\mathrm{a}}$ parte. Em Heintze. Fontes para a história de Angola.1985. Vol.I.doc.24. p. 199. Neste documento, Fernão de Sousa criticou o Bispo Simão de Mascarenhas, por não ter pedido o herdeiro ao jaga Caza para "metelo no Reyno em nome de Vossa Magestade com que ficava tudo seguro”.
} 
a deslegitimá-la. Em 1631, em retrospectiva, ele criou a imagem de que Nzinga tinha uma antiga aversão aos portugueses e ao cristianismo e não poderia jamais negociar. ${ }^{406}$

Em 1632, a Ordem da Mesa do Paço pediu a Fernão de Sousa que justificasse as razões que teve para fazer guerra a Nzinga e privá-la do reino ${ }^{407}$ Em 1641, o Conselho Ultramarino chegou à conclusão de que Nzinga tinha o direito à dignidade do título Ngola e de que ela deveria ser reinvestida. Censurou o "procedimento de Fernão de Sousa em ter tirado a realeza a Jinga", e afirmou que só a ela "assistia o direito e a justiça, e (que) tudo isto (tinha sido) calcados". 408

Mais difícil ainda é acreditar no silêncio das tradições orais atuais sobre Nzinga. Em suas pesquisas junto aos Mbangala do Malanje, Miller concluiu que, assim como seus rivais conseguiram expulsar de Matamba os sucessores que ela designou, o nome de Nzinga Mbandi foi omitido das tradições orais daquele estado. ${ }^{409}$ Miller talvez tenha percebido isto porque sua pesquisa foi exclusivamente junto aos descendentes de Cassanje, historicamente rivais de Nzinga, e que teriam intenções de anulá-la da história do Ndongo.

Nzinga é hoje recordada por muitas etnias de Angola e é considerada uma heroína nacional, indo sua memória além das fronteiras etno-culturais Mbundo. Parreira se posicionou contrario a este "silêncio das tradições" levantado por Miller:

\footnotetext{
"Durante o tempo colonial, as histórias muitas vezes fantasistas sobre a rainha Jinga, eram contadas às crianças constituindo uma história paralela à institucionalizada pelos portugueses. Nos últimos 100 anos, a literatura e a poesia angolana têm privilegiado a rainha Jinga como tema central em algumas obras e ensaios, mas é sobretudo na região do antigo Ndongo, que a "figura de Jinga é protagonista" das lendas e dos mitos tradicionais que perpetuaram na memória de todas as gerações o lugar venerável que lhe é reservado." 410
}

\footnotetext{
${ }^{406}$ História das relações entre a Angola portuguesa e o Ndongo- 1624 - 1631. $3^{\text {a }}$ parte. Em Heintze. Fontes para a história de Angola.1985. Vol.I.doc.24. p.20I-202.

${ }^{407}$ Ordem da Mesa do Paço a Fernão de Sousa. Fontes para a história de Angola.1988. Vol.II. doc.236. p. 337.

${ }^{408}$ Consulta do Conselho Ultramarino, de 19/10/1641. Em Cardonega. Vol. I. p. 216, 166-167. nota do editor.

${ }^{409}$ Miller, 'Queen Nzinga of Matamba in a new perspective'. p. 2 I6.

${ }^{410}$ Parreira, Adriano. Economia e sociedade na época da Rainha Jinga. P.183.
} 


\section{Conclusões}

\section{Nzinga e a luta contra o tráfico negreiro}

Talvez seja "romântico" afirmar que Nzinga travou uma luta contra o tráfico negreiro. Em um contexto em que a moeda corrente em Angola era o escravo e que a escravidão já era, há muito, instituída, parece falta de realismo afirmar que Nzinga tentou impedir o tráfico negreiro. Mas sem querer idealizar esta personagem, tentamos defender a ideia de que Nzinga Mbandi contribuiu para a diminuição do tráfico negreiro, pelo menos no período em que se acirrou a rivalidade contra os portugueses, entre 1624-1641. Talvez não fosse uma luta ideológica contra a escravidão, provavelmente não era e é difícil supor que isto fosse possível em pleno século XVII, mas suas ações acabaram por ter esta consequência.

Primeiramente, ao conceder exílio aos escravos fugidos, Nzinga contribuiu para aumentar a esperança de liberdade. Sob sua proteção, esses indivíduos conseguiram se libertar do jugo da escravidão imposta pelos portugueses. Nota-se que não foram poucos, "mas senzalas inteiras" como uma movimentação anti-escravatura que ocorreu de forma maciça em Angola no século XVII.

Outra forma de atuar contra a expansão do tráfico negreiro foi o impedimento das feiras, que Nzinga conseguiu articular, principalmente nas décadas de 1620-1630. A feira de Ndala Kisua foi a principal aposta portuguesa de retomar o comércio de escravos no interior, mas Nzinga em diversas investidas, conseguiu paralisar as atividades ali. Nesta articulação, o Jaga Kalunga Kakwanza bloqueava a rota do Mbondo, provocando a imediata diminuição dos escravos que eram outrora encaminhados para Luanda ${ }^{412}$. O isolamento do Mbondo aos comerciantes de Luanda, provocado pelas ofensivas de Nzinga, afetou drasticamente o tráfico transatlântico. Em 1627, os pumbeiros de Luanda tentaram articular uma feira na libata de Ndala Kisua, no Mbondo, do outro lado do rio Keze, e Nzinga conseguiu impedir seu funcionamento.

\footnotetext{
${ }^{411}$ Carta de Fernão de Souza ao Governo. 6 de setembro de 1625. Heintze, 1988. Documento 60. p. 142.

${ }^{412}$ Heintze. Angola nas garras do tráfico de escravos: as guerras do Ndongo (1611-1630). Revista Internacional de Estudos Africanos. Lisboa. Vol.I, p. 47. 1984. E Heintze, 1985. P.203.
} 
A feira de Pungo-a-Ndongo também foi diversas vezes atacada por Nzinga e pelos Jagas sob seu comando, principalmente enquanto travava a ferrenha luta contra Ngola Are, entre os anos de 1624 a $1631 .^{413}$ Não apenas Nzinga combatia a organização do comércio de escravos: ainda em 1611, os sobas do Lumbo atacaram as feiras realizadas em Ango ${ }^{414}$, obrigando os portugueses, sob o comando de Bento Banha Cardoso, a criarem o presídio do mesmo nome para se protegerem e garantir o funcionamento da feira. Os habitantes da Quissama, desde o início da presença portuguesa na região, impediam a navegação no rio Kwanza, a principal via de acesso dos escravos à Luanda, desarticulando assim a malha que sustentava o tráfico negreiro. O Ndembo Ambuila, com o apoio de importantes chefes do norte do Ndongo, como Kakulo Kakabonda e Kiluanje Kakango, também conseguiu interditar a feira que era realizada em Ambuíla após o ataque português em 1626 que visava tomar posse das minas de cobre da Mbamba. ${ }^{415}$

Talvez o grande êxito de Nzinga tenha sido unir todos estes chefes descontentes com a presença portuguesa em uma grande confederação. Ela conseguiu agregar o mani Congo, os sobas da Quissama, do Lumbo, do Libolo, dos Songo e alguns sobas do Kwanza em torno de sua campanha contra os portugueses. Assim, ela se tornou uma referência política para além das fronteiras de seu antigo reino, tornou-se uma liderança que atuava em diversos territórios da África cento-ocidental, levantando a bandeira de luta contra a presença portuguesa, como muitas vezes admitiu Cardonega. ${ }^{416}$

Se sua luta não era diretamente contra o tráfico de escravos, indiretamente ela atingiu este objetivo, atacando a principal motivação da presença portuguesa em Angola, que era justamente o comércio de escravos. Tanto que Fernão de Sousa, no término de seu mandato, justificou-se pelo fracasso econômico da colônia, alegando que

\footnotetext{
${ }^{413}$ Extenso relatório do governador a seus filhos. 1630. Em Heintze, 1985. Doc.30.p. 227.

${ }^{414}$ Cardonega. História Geral das guerras angolanas. Vol.I.p.77.

${ }^{415}$ Heintze. Angola nas garras do tráfico de escravos: as guerras do Ndongo (1611-1630). Revista Internacional de Estudos Africanos. Lisboa. Vol.I, p. 47. 1984.

${ }^{416}$ Cadornega. Vol. I. p. 82 e seguintes. O autor fala, em diversas passagens, que o principal objetivo de Nzinga era eliminar a presença portuguesa em Angola.
} 
não havia feiras porque Nzinga sempre as desfazia e as constantes guerras que se davam contra ela dificultavam a organização do comércio. ${ }^{417}$

Nzinga também conseguiu desarticular a colonização portuguesa através de ações militares que impediram a cobrança dos baculamentos, como organizou em 1625. Fernão de Sousa registrou que muitos sobas se negavam a pagar os tributos e passaram para o lado de Nzinga, prejudicando consideravelmente a receita portuguesa. ${ }^{418}$ Temendo perder todos os sobas aliados para as fileiras de Nzinga, o governador recomendava suavidade nas cobranças. Lembrando que os baculamentos eram pagos, na maioria das vezes, em peças da Índia, podemos afirmar que a atuação militar de Nzinga impediu que centenas de pessoas fossem dadas como escravas aos portugueses.

O sucessor de Fernão de Sousa, Manuel Pereira Coutinho, noticiou ao rei que a guerra entre Nzinga e Ngola Are pelo reino do Ndongo levava a insubmissão de muitos sobas e a fuga de outros tantos deixava as terras desertas, sem "haver trato e comércio por estarem os caminhos tapados e impedidos". 419 O governador lamentava que os partidários de Nzinga faziam o que queriam, assaltando até os presídios.

Alguns historiadores ${ }^{420}$ destacaram as atividades de Nzinga enquanto articuladora do tráfico negreiro, principalmente durante a invasão holandesa (16411648), em que Matamba, sob seu domínio, passou a ser o maior exportador de escravos da região. De fato, não se pode negar o envolvimento de Nzinga com esta atividade, a mais lucrativa na época, que lhe garantia o acesso a mercadorias disputadas, como armas de fogo e munições. Mas discordo do posicionamento de Miller, que parece querer acusa-la de ser uma das principais agentes deste tráfico, anulando sua ação contrária ao comércio de escravos. Se por um lado, não devemos romantizar a personagem, também não podemos responsabilizá-la pelas maiores atrocidades que ocorreram em sua época. Culpar os africanos pela existência do tráfico parece ser uma

\footnotetext{
${ }^{417}$ Informação de Fernão de Sousa ao Conselho da Fazenda. 11 de julho de 1631. Em Heintze, Fontes para a História de Angola. Vol. II. Doc. 232. P. 333.

${ }^{418}$ Carta de Fernão de Sousa sobre os tributos de vassalagem dos sobas. 8 de julho de 1626. Em Heintze. Fontes para a História de Angola. Vol. I. doc. 31. P.364.

${ }^{419}$ Carta de Manuel Pereira Coutinho ao rei. 3 de Março de 1632.Em Heintze, Fontes para a História de Angola. Vol. II. Doc. 237. P.337.

${ }^{420}$ Miller, "Queen Nzinga of Matamba in a new perspective". p. 201 "kept African politics in a state of turmoil, and helped to develop the Angolan slave trade from the 1620s to the 1660s".E Glasgow. Nzinga. Resistência Africana à investida do colonialismo português em Angola.1582-1663. P.121-127
} 
opção que tende a eximir os europeus do papel que tiveram na articulação da escravidão atlântica.

As várias faces de Nzinga Mbandi

Nzinga Mbandi, ao longo de sua trajetória política, desempenhou múltiplos papéis, que poderiam ser considerados contraditórios, mas que se analisados no contexto político Mbundo do século XVII, revelam a sua luta pelo poder e para manter seu povo- ou povos que a ela iam se agregando- livres do julgo colonial.

O batismo realizado em 1622 lhe permitiu maior aproximação com as autoridades lusas, mas não garantiu o cumprimento do acordo de paz assinado naquela ocasião. Desta forma, podemos afirmar que foram as atitudes dos próprios governantes portugueses que afastaram Nzinga Dona Anna de Souza do cristianismo, pois foram eles os primeiros a descumprirem o combinado, levando Ngola Mbandi à morte.

Nzinga assumiu o trono do Ndongo em 1624 enquanto regente de seu sobrinho ainda menor, e se auto intitulou "senhora de Angola". ${ }^{421}$ Com o assassinato do sobrinho e a tomada das insígnias de poder, Nzinga tomou posse do título Ngola, reivindicando a soberania do Ndongo e sua legitimidade para governar o reino.

O golpe político arquitetado por Fernão de Sousa em 1626 tirou-lhe o trono do Ndongo, mas ela jamais aceitou a perda. Fortificou-se em Kindonga e buscou apoio nos Jagas para garantir seu poder pelas armas. A aliança com os Jagas-Mbangala foi uma estratégia para se reforçar militarmente e conseguir sobreviver - material e politicamente- diante da intensa perseguição que lhe fazia o governo português.

Junto ao kilombo do Jaga Caza Cangola, Nzinga recebeu o mais importante título feminino, o de tembanza, assumindo funções rituais centrais naquela organização. Nzinga extravasou o papel original de tembanza e passou a comandar pessoalmente as batalhas como grande líder militar, fazendo reviver a personagem mitológica de Temba Ndumba. Seu prestígio junto à comunidade Jaga-Mbangala não se restringiu ao grupo dirigido por Caza, sendo considerada líder de vários outros bandos Jagas. A união com

${ }^{421}$ Carta de Fernão de Sousa ao governo. 15/8/1624. Em Heintze. Fontes para a história de Angola. 1988. Vol.II p.85. doc. 36 
Cassanje representou bem este prestígio, uma vez que foi aceita como mulher de um dos mais importantes chefes Jagas da época.

Ainda como Jaga, Nzinga conquistou Matamba, aproximadamente em 1630. A ação não teria encontrado muita resistência entre a classe dirigente de Matamba, que foi mantida no poder com importantes cargos públicos. ${ }^{422} \mathrm{~A}$ aceitação de Nzinga como soberana de Matamba deve ter passado pela ancestralidade comum aos dois reinos. Os governantes de Matamba reconheceram em Nzinga a capacidade de mantê-los livres, no conturbado cenário político do século XVII. Em Matamba, Nzinga criou um estado inteiramente novo a partir das instituições Mbangala, onde pôde se manter soberana e independente.

A chegada dos holandeses a Angola trouxe novas possibilidades de acessar as mercadorias europeias e aumentar as receitas e o poder em Matamba. O apoio mútuo aos holandeses trouxe o enriquecimento de Matamba, que, juntamente com o Congo e Cassanje tornaram-se os mais importantes estados da África Central no século XVII.

Depois de derrotados os holandeses, a chegada dos padres capuchinhos italianos, a partir da década de 1650, renovou as esperanças de ter aliados externos nãoportugueses. Os enviados da Propaganda Fide ofereceram a Nzinga a possibilidade de aceitar o cristianismo mais uma vez e sair da crise em que seu estado se encontrava. Finalmente, Nzinga negou as crenças Mbangala, justificando seu comportamento como Jaga durante todos aqueles anos (1624-1655) pela ação dos governantes portugueses, que lhe furtaram o reino a obrigando a viver errante.

Assim, Nzinga acumulou os designativos de cristã, Ngola, tembanza, rainha de Matamba. E para ela, um não anulava o outro. Mesmo sendo consagrada Jaga e tendo assumido o trono de Matamba, ela nunca desistiu de reivindicar ao trono do Ndongo. Ao mesmo tempo, que comandava seus kilombos contra os portugueses, dirigiu-se aos governantes portugueses como cristã, assinando Dona Anna de Sousa, colocando-se como fiel à coroa ibérica. Ao mesmo tempo em que mantinha aceso o conflito com Portugal, escrevia ao Papa como "filha obedientíssima." 423

\footnotetext{
${ }^{422}$ Cavazzi. Vol.II. p. 132.

423“CCarta de Jinga ao Papa.”. Em Cavassi.vol. II. P. 236. Anexos.
} 
Esta dissimulação pela qual ficou conhecida pode ser entendida como mais uma estratégia para se manter livre diante da acirrada perseguição. Nzinga soube perceber as dificuldades que enfrentava e tentou vencê-las de qualquer forma. As várias alianças representam sua luta para se manter no poder.

Seria contraditório reivindicar a soberania do povo Mbundo ao mesmo tempo em que lutava como uma Jaga - povo que pilhava e destruía as comunidades Mbundo? Como sendo rainha de Matamba, ela reivindica seu direito ao trono do Ndongo?

Para resolver estas aparentes contradições, levantamos a hipótese de que no século XVII, devido à instabilidade política gerada pela presença portuguesa e as consequentes guerras, as fronteiras territoriais e étnicas estavam sendo redefinidas. A grande movimentação de pessoas que ocorreu no século XVII provocou uma nova configuração populacional nos reinos da África Cental. Fernão de Sousa reclamava que grande parte da população do Ndongo estava se dirigindo à Matamba, ao Songo e ao Mbondo, por não aceitarem a autoridade dada a Ngola Are. ${ }^{424}$ Assim, muitos daqueles que estavam em Matamba sob o governo de Nzinga eram originários do Ndongo, da etnia Mbundo. Da mesma forma, os que lutavam ao lado de Nzinga como Jagas poderiam ser refugiados Mbundo ou de qualquer outra etnia, e assumiram a designação Jaga tal como Nzinga o fizera, mas poderiam não estar vinculados às antigas rivalidades que existiam entre Jagas e Mbundo.

A autoridade de Nzinga foi concedida por pessoas das mais diversas origens étnicas. A formação da etnia "Jinga", que ganhou visibilidade a partir do final do século XVII, principalmente no nordeste de Angola, pode ser uma evidência desta nova configuração política e étnica que surgiu com a trajetória de Nzinga Mbandi.

A personagem Nzinga Mbandi jamais foi retirada da memória de Angola e seu nome está ligado à história da resistência africana frente ao colonialismo europeu. Como bem sintetisou Marina de Mello e Souza, Nzinga Mbandi “é um exemplo de como eventos históricos podem ser congelados, mitificados, ritualizados e evocados na constituição de identidades." ${ }^{425}$

\footnotetext{
${ }^{424}$ Extenso relatório do governador a seus filhos. 1630. Em Heintze, 1985. Doc.30.p. 258.

${ }^{425}$ Souza, Marina de Mello e. Reis negros no Brasil escravista. p. 114.
} 
Os diversos papéis por ela desempenhados atestam sua capacidade de perceber as novas realidades que a presença portuguesa trouze e mostram sua flexibilidade em buscar as alianças mais interessantes de acordo com as circunstâncias; mostram sua habilidade de governar povos de diferentes origens e revelam sua astúcia para atuar tanto diplomaticamente como pelas armas.

Nzinga Mbandi veio ao Brasil na memória de seus soldados escravizados, que se libertaram e fizeram reviver a organização militar dos kilombos. Aqui, mais uma vez se disfarçou, tornou-se a Ginga, que aparece nas danças, no congado, no futebol, na capoeira, sempre seduzindo e enganando. 


\section{Fontes:}

BRÁSIO, Antônio. Monumenta Missionária Africana. Lisboa: Agência Geral do Ultramar, 1952.

BRITO, Domingos de Abreu e. Um inquérito à vida administrativa e económica de Angola e do Brasil em fins do século XVI (1591). Editado por Alfredo de Albuquerque Lima Felner. Coimbra: Imprensa da Universidade, 1933.

BRITO, Domingos de Abreu e. Sumário e descripção do reino de Angola e do descobrimento da ilha de Loanda e da grãdeza das capitais do Estado do Brasil (1592). Notas A. de Alburqueque Felner. Coimbra, 1931

CAVAZZI,Giovanni. Descrição histórica dos três reinos do Congo, Matamba e Angola. Lisboa : Junta de Investigações do Ultramar, 1965.

Cartas do rei do Congo D. Afonso. Introdução, notas e comentários e modernização do texto por Antonio Luiz Ferronha. Grupo de Trabalho do M. da Educação para as comemorações dos Descobrimentos Portugueses.

CARNODEGA, História geral das guerras angolanas.( 1681). 3 vols. Ed. Anot. Cônego José Mathias Delgado (vols.1 e 2) e Manuel Alves da Cunha (vol.3). Lisboa, 1972

CORDEIRO, Luciano. Viagens, explorações e conquistas dos Portugueses. Colleção de documentos. Lisboa, 1881

CORDEIRO, Luciano. Questões Históricos coloniais. Lisboa: Agência Geral das Colônias, 1935. V.1.

DIAS, Gastão de Sousa. Relações de Angola: primórdios da ocupação portuguesa pertencentes ao cartório do Colégio dos Padres da Companhia, de Luanda, e transcritas do códice existente na Biblioteca Nacional de Paris. Coimbra: 1934.

FELNER, Alfredo de Albuquerque. Angola. Apontamentos sobre a ocupação o inicio do estabelecimento dos Portugueses no Congo, Angola e Benguela extraídos de documentos históricos. Coimbra: Imprensa da Universidade, 1933.

FELNER, Luis de Albuquerque.(org.) Angola no século XVI. Comentários de A.L.A. Ferronha. Publicações Alfa Lisboa, 1989.

GIOIA DA NAPOLI, Frei. La maravigliosa conversione alla Santa Fede di Cristi della Regina Sina e del suo regno di Matamba (1669). Napóles, 1669.

HEINTZE, Beatrix. Fontes para a história de Angola. Vol.I. Memórias, relações e outrosmanuscritos da Colectânea Documental de Fernão de Sousa (1622-1635). Studien zur Kulturkunde, Bd. 75. Stuttgart: Steiner 1985.

HEINTZE, Beatrix. Fontes para a história de Angola. Vol.II. Cartas e documentos oficiais daColectânea Documental de Fernão de Sousa (1624-1635). Studien zur Kulturkunde, Bd. 88. Stuttgart: Steiner 1988. 
LOPEZ, Duarte e PIGAFFETTA, Filippo. Relação do reino do Congo e das terras circunvizinhas. Comentário e transcrição por Alberto Ferronha. Lisboa: Alfa, 1989. Primeira edição: Relatione del reame di Congo ...Roma. 1591

RAVESTEIN, E (org.) The strange adventures of Andrew Battel pf Leigh in Angola and the Adjoining regions. London : The Hakluyt Society ,1901.

RODRIGUES, Francisco. Uma história inédita de Angola: ms.do século XVI. Lisboa, [s.n], 1936.

\section{Referências bibliográficas:}

ALENCASTRO, Luiz Felipe de. O trato dos viventes: formação do Brasil no Atlântico Sul. Séculos XVI e XVII. São Paulo: Companhia das Letras, 2000.

AMARAL, Ilidío do. O reino do Congo, os Mbundu (ou Ambundos), o reino dos "Ngola" (ou de Angola) e a presença portuguesa de finais do século XV a meados do século XVI. Lisboa: Ministério da Ciência e da Tecnologia, Instituto de Investigação Científica Tropical, 1996.

AMARAL, Ilidío do. O consulado de Paulo Dias de Novais: Angola no último quartel do século XVI e primeiro do século XVII. Lisboa: Instituto de Investigação Científica Tropical, 2000.

BIRMINGHAM, David. "The Date and Significance of the Imbangala Invasion of Angola." The Journal of African History, Vol. 6, No. 2 (1965), pp. 143-152.

BISSON, M.S. "Trade and tribute.Archeological Evidence for the Origin of States in South Central Africa.’Em Cahiers d'Études Africaines . 1986. Pp343-361.

BONTINCK, François. «Un mausolée por les Jaga.» Cahiers d'Etudes Africaines, v 20, n.79. p. 387-389. 1980.

BOXER, Charles. O Império Marítimo português. 1415-1825. São Paulo: Companhia das Letras, 2002.

BOXER, Charles. Salvador de Sá e a luta pelo Brasil e Angola. 1602-1686. Tradução de Olivério M. de Oliveira Pinto. São Paulo: Companhia Editora Nacional, 1973.

CARVALHO, H. Dias de. O Jagado de CassangeLisboa, Typ. de Cristovão Augusto Rodrigues,1898. Disponível em: http://www.archive.org

CASCUDO, Luis da Câmara. Made in África. Rio de Janeiro: Civilização Brasileira, 1965.

CASTELBRANCO, Francisco. Histórias de Angola. Luanda, 1932. 
CASTILHON, J.-L. Zingha, Reine d'Angola. Histoire Africaine. Bourges: Edition de l'Association Gaymede, 1993.

CORRÊA, Elias Alexandre da Silva. História de Angola. Lisboa: Agência Geral das Colônias, 1937. 2v.

CORTESÃO, Jaime. Os portugueses em África. Lisboa: Portugália, 1968.

COSTA E SILVA, Alberto da.A manilha e o libambo. Rio de Janeiro: Nova Fronteira, 2002.

CURTO, Diogo Ramada. Cultura imperial e projetos coloniais: séculos XV a XVIII. Campinas, SP: UNICAMP, 2009.

CURVELIER, Jean. L'ancien royaumme de Congo. Fondation, decouverte, premiere evangelisation de l'ancien royaume de Congo, regne du grand roi Affonso Mvemba Nzinga. Bruxelas: Desclée de Brouwer, 1946.

DELGADO, Ralph. História de Angola : $2^{\mathrm{a}}$ ed rev. corrig.. - Lobito : Livraria Magalhães, 1961. - 4 vols. (primeiro e segundo volume: 1482 a 1607. - Luanda : Banco de Angola- 2 vol. : il., mapas. - Inclui obras do autor.- Lista dos reis do Congo e Portugal e índices. ) terceiro e quarto volume: 1648 a 1836.

FARINHA, Padre Lourenço. A expansão da fé na África e no Brasil. Lisboa: Divisão de Publicações e Biblioteca. Agência Geral das Colônias. 1942.

FURTADO, Junia. Sons, cores e formas e movimentos na Modernidade Atlântica: Europa, América e África. Belo Horizonte: EDUFMG, 2008.

GARCIA, Carlos Alberto. Paulo Dias de Novais e a sua época. Agência Geral do Ultramar, 1964.

GLASGOW, Roy. Nzinga. Resistência africana à investida do colonialismo português em Angola, 1582-1663. São Paulo Editora Perspectiva, 1982.

GRAY, Richard. "Portuguese Musketeers on the Zambezi". Em: Journal of African History, 12:4 (1971), pp. 531-533.

HALBWACHS, Maurice. Memória coletiva. São Paulo: Vértice, 1990.

HEGEL, G.W. La raison dans l'histoire. Trad. E notas Kostas Papaoiannou. Paris, 1965. 
HEINTZE, Beatrix. Historical notes on the Kisama of Angola. Jornaul of African History, XIII (3), 1972.

HEINTZE, Beatrix. Angola nas garras do tráfico de escravos: as guerras do Ndongo (1611-1630). Revista Internacional de Estudos Africanos. Lisboa. Vol.I, p. 47. 1984.

HEINTZE, Beatrix. Angola nos séculos XVI e XVII. Estudos sobre Fontes, Métodos e História, Luanda: Kilombelombe, 2007.

HEYWOOD, Linda e THORNTON, John. Central africans, atlantic creoles, and the fondation of the Americas, 1585-1660. Cambridge: Cambridge University Press, 2007.

HILTON, Anne. "The Jaga reconsidered". The Journal of African History. Vol.22.n.2 (1981)pp.191-202. Cambridge University Press.

LABAT, Jean Baptiste. Relation historique de l'Ethiopia Occidentale. 5 tomos.Paris, 1732.

LAW, Robin. The horse in West african history: the role of the horse in the societies of pre-colonial West Africa.London, 1980.

LÉPINE, Claude. Dois Reis Do Danxome Africa Sakpata Oduduwa: Varíola e monarquia na África Ocidental. Cultura acadêmica, 2000.

LOPES, Nei. Novo Dicionário Banto do Brasil. Rio de Janeiro: Editora Pallas, 1999.

MILLER, Joseph. "The Imbangala anfd the cronology of Early Central African History ».The Journal of African History, Vol. 13, n.4, 1972.

MILLER, Joseph."Note on Casanze and the Portuguese". Canadian Journal of African Studies, v. 6, n. I, 1972.

MILLER, Joseph. "Requiem for the Jaga."Cahiers d'Etudes Africaines, v. 13, n.49.p.121-149, 1973.

MILLER, Joseph."Nzinga of Matamba in a new perspective". The Journal of African History. V.6, n.2, 1975.

MILLER, Joseph. Poder político e parentesco: os antigos estados Mbundu em Angola. Trad. De Maria da Conceição Neto. Luanda: Arquivo Histórico Nacional, 1995. Título original: Kings and Kinsmen: early Mbundu States in Angola. Oxford: Claredon Press, 1976.

MILLER, Joseph.“Thanatopsis.” Cahiers d'Etudes Africaines, , v.18, n.1-2, 1978.

MILLER, Joseph \& THORTON, J.K. "The chonicle as source, history and hagiography - The Catálogo dos governadores de Angola» Paideuma, 33, 1987. 
NEVES, Antônio Rodrigues. Memória da Expedição a Cassange. Lisboa, 1854.

PACAVIRA, Manuel Pedro. Nzinga Mbandi : romance /. 2. ed. Lisboa: Edições 70, 1979

PAIVA MANSO, Visconde de. História do Congo: documentos. Lisboa: Tipografia da Academia Real das Ciências de Lisboa, 1877

PANTOJA, Selma Alves. Nzinga Mbandi.mulher, guerra e escravidão. Brasília: Thesaurus, 2000.

PANTOJA, Selma Alves.Fontes para a História de Angola no Rio de Janeiro do século XVI a XIX. In: Revista Internacional de Estudos Africanos, nº 8-9, 1988.

PARREIRA, Adriano. Dicionário glossográfico e toponímico da documentação sobre Angola, séculos XV-XVII. Lisboa, 1990.

PARREIRA,Adriano. Economia e sociedade na época da rainha Jinga. (Século XVII). Lisboa: Editorial Estampa, 1997.

REDINHA, José. Boletim Cultural da Câmara Municipal de Luanda, No 23, Abril Junho, 1969. Páginas 25-31.

REDINHA, José. Distribuição étnica de Angola, Luanda: Centro de Informação e Turismo de Angola. 8 ${ }^{a}$ edição. 1974.

REDINHA, José. Etnias e culturas de Angola. Luanda: Instituto de Investigação Científica de Angola, 1975.

ROCHA, Manoel Ribeiro. Etíope resgatado Empenhado, Sustentado, Corrigido, Instruído e Libertado. Rio de Janeiro: Editora Vozes, 1992. (Escrito em 1758).

SANDOVAL, Alonso de. Um tratado sobre la esclavitud. Madrid, 1987. Ed. Org. E. Vila Vilar. Título original: Naturaleza, policia sagrada i profana, costumbres e ritos, disciplina i catecismo evangélico de todos los etíopes (1627). Reed. 1647 em latim com o títuo de instauranda Aethiopium saute.

SANTOS, Eduardo dos. Religiões de Angola. Lisboa, Junta de Investigações do Ultramar, 1969.

SERRANO, Carlos. "Ginga, a rainha quilombola de Matamba e Angola". Revista Africa ( USP), nº 28, 1997.

SCHOFFELEERS, Matthew. "The Zimba and the Lundu State in the Late Sixteenth and Early seventeenth century." The Journal of African History, v. 28, .3, 1987.

SILVA, Juliana Ribeiro. Homens de ferro. Os ferreiros na África Central do século XIX. Dissertação de Mestrado defendida na USP. Julho de 2008.

SILVA REGO, Antônio da.A dupla restauração de Angola. 1641-1648. Lisboa, Divisão de Publicações e Biblioteca Agência Geral,1956. 
SOUZA, Marina de Mello e. Reis negros no Brasil escravista: história da festa de coroação de rei Congo. Belo Horizonte: Editora UFMG, 2002.

SOUZA, Marina de Mello e. Catolicismo e comércio na região do Congo e de Angola, séculos XVI e XVII. Em FRAGOSO, João; FLORENTINO, Manolo et alii( orgs).Nas rotas do império. Vitória: EDUFES, Lisboa: IICT, 2006, pp. 279-298.

SOUZA, Marina de Mello e. A rainha Jinga - África central, século XVII. Em ComCiência Revista Eletrônica de Jornalismo Científico. 2008.

SOUZA, Marina de Mello e .A rainha Jinga de Matamba e o catolicismo. África Central, século XVII. Em FERREIRA, Jerusa Pires e ÁREAS ,Vilma (orgs.) Marlyse Meyer nos caminhos do imaginário. São Paulo: EDUSP, 2009, pp. 153-182.

THORNTON, John. «A ressurection for the Jaga». Cahiers d'Études Africaines, v.18, n 69, p. 223-227. 1978.

THORNTON, John.Early Kongo-portuguese relations :a new interpretation. In : HENIGE, David (ed.) History in Africa. A journal of Method. Massachusetts Brandeis University, African Studies Association, v. 8, p. 183-204. 1981.

THORNTON, John. "The Art of war in Angola, 1575-1680".Comparative Studies in Society and History, vol. 30.N.02. (Abril, 1988).Pp.360-378.Cabridge University Press.

THORNTON,John. “Legitimacy and Political Power: Queen Njinga, 1624-1663”. The Journal of African History, Vol. 32, No. 1 (1991), pp. 25-40. Cambridge University Press.

VANSINA, Jan. "More on the Invasions of Kongo and Angola by the Jaga and the Lunda".The Journal of African History, Vol. 7, No. 3 (1966), pp. 421-429

VANSINA, Jan. "The Foundation of the Kingdom of Kasanje". The Journal of African History. Vol. 4, No. 3 (1963), pp. 355-374.

VANSINA, Jan.Oral tradition.Chigago, 1966.

VANSINA, Jan ."Once upon a time: oral tradition as History in Africa”. Daedalus.c.2.1971.pp. 442-468.

VANSINA, Jan. "Long distance Trade- routes in Central Africa".The Journal of African History.Vol.III, n³, 1962.P. 375

VANSINA, Jan. How societies are born.Governance in West Central Africa Before 1600. Charlottesville, Virginia: University of Virginia Press. 2004

VANSINA, Jan; OBENGA, T. "The Kongo Kingdon and its neighbours." Em: UNESCO, General History of Africa. London: Heinemann; Berkeley: University of California Press, 1992, v.5. 
ZERON, Carlos. Les jésuites et le commerce d'esclaves entre le Brésil et l'Angola à la fin du XVIe siècle: contribution à un débat. Traverse, 3e année, 1, Zurique, 1996, pp. 34-50. 


\section{ÍNDICE DE IMAGENS E MAPAS}

\section{PÁGINA}

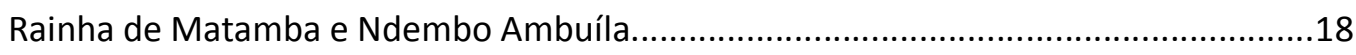

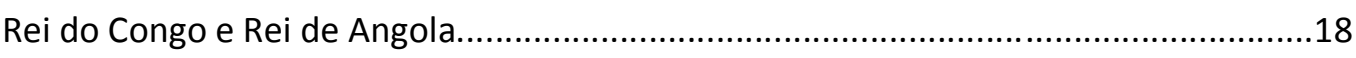

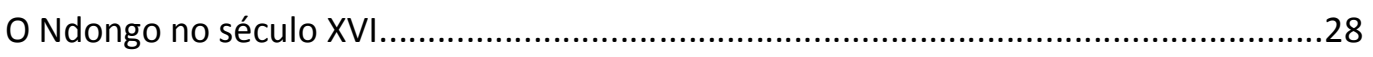

As três hipóteses de Heintze sobre a seriação dos ngola............................................... 31

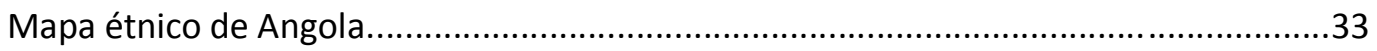

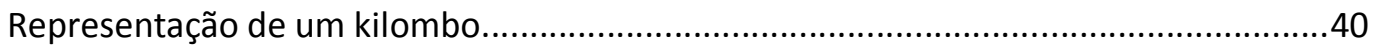

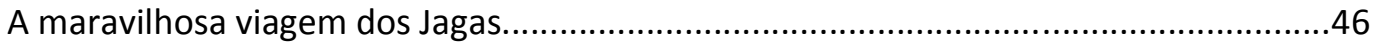

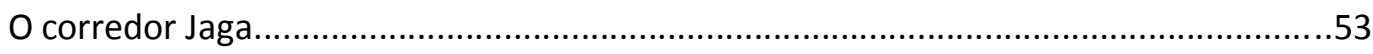

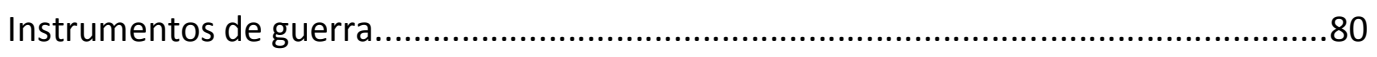

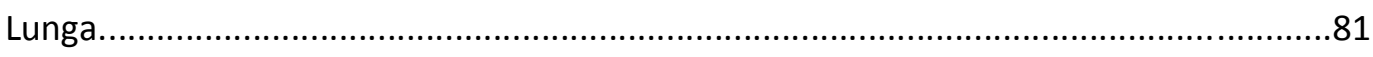

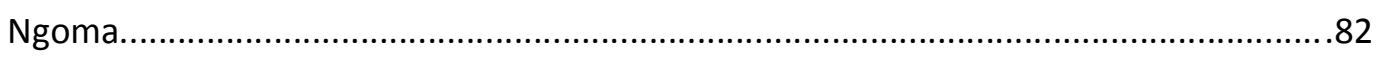

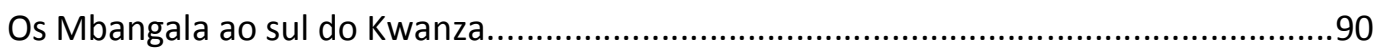

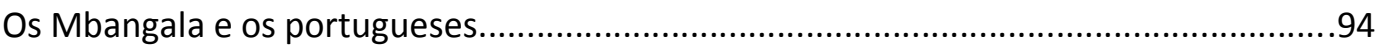

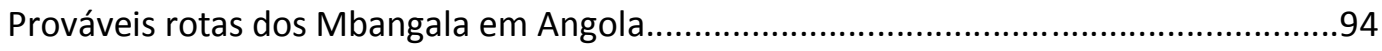

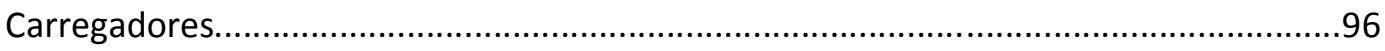

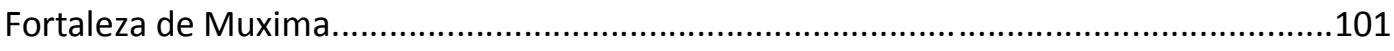

Fortalezas portuguesas erguidas nos séculos XVI e XVII ao longo do rio Kwanza.............102

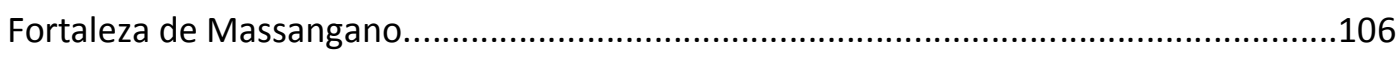

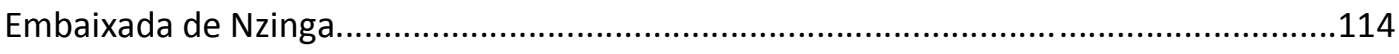

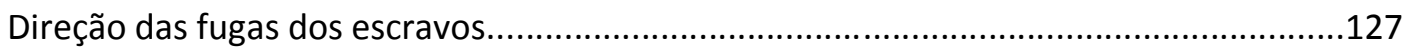

